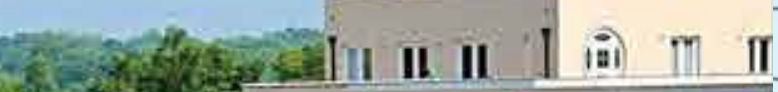 EXPLORING THE \\ IIII \\ iili $-$ Architecture of Place IN \\ America's Farmers Markets \\ KATHRYN CLARKE ALBRIGHT \\ ,

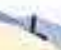 \\ a
}

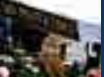
19 4

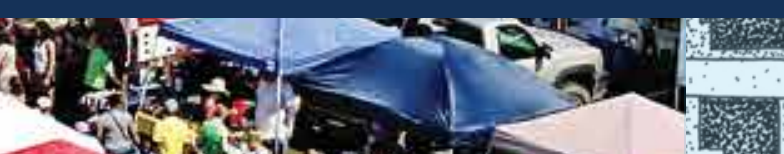

it $\rightarrow$ of

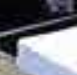

1.

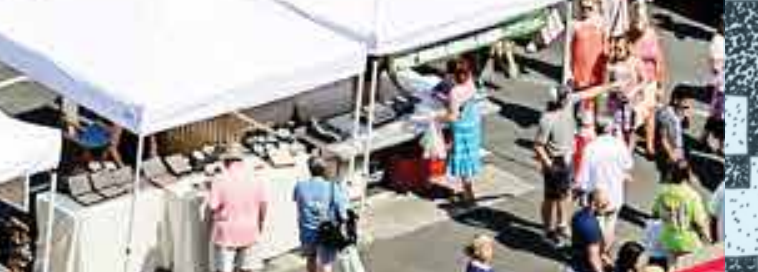

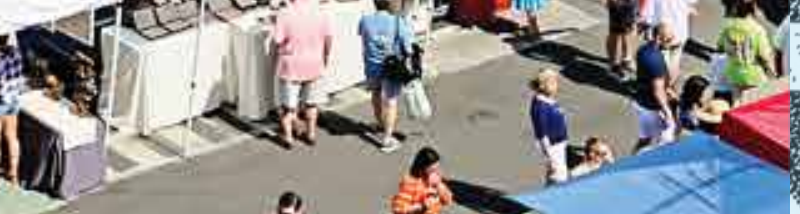




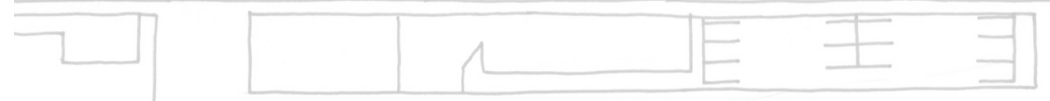

\section{EXPLORING THE ARCHITECTURE OF PLACE IN AMERICA'S} FARMERS MARKETS
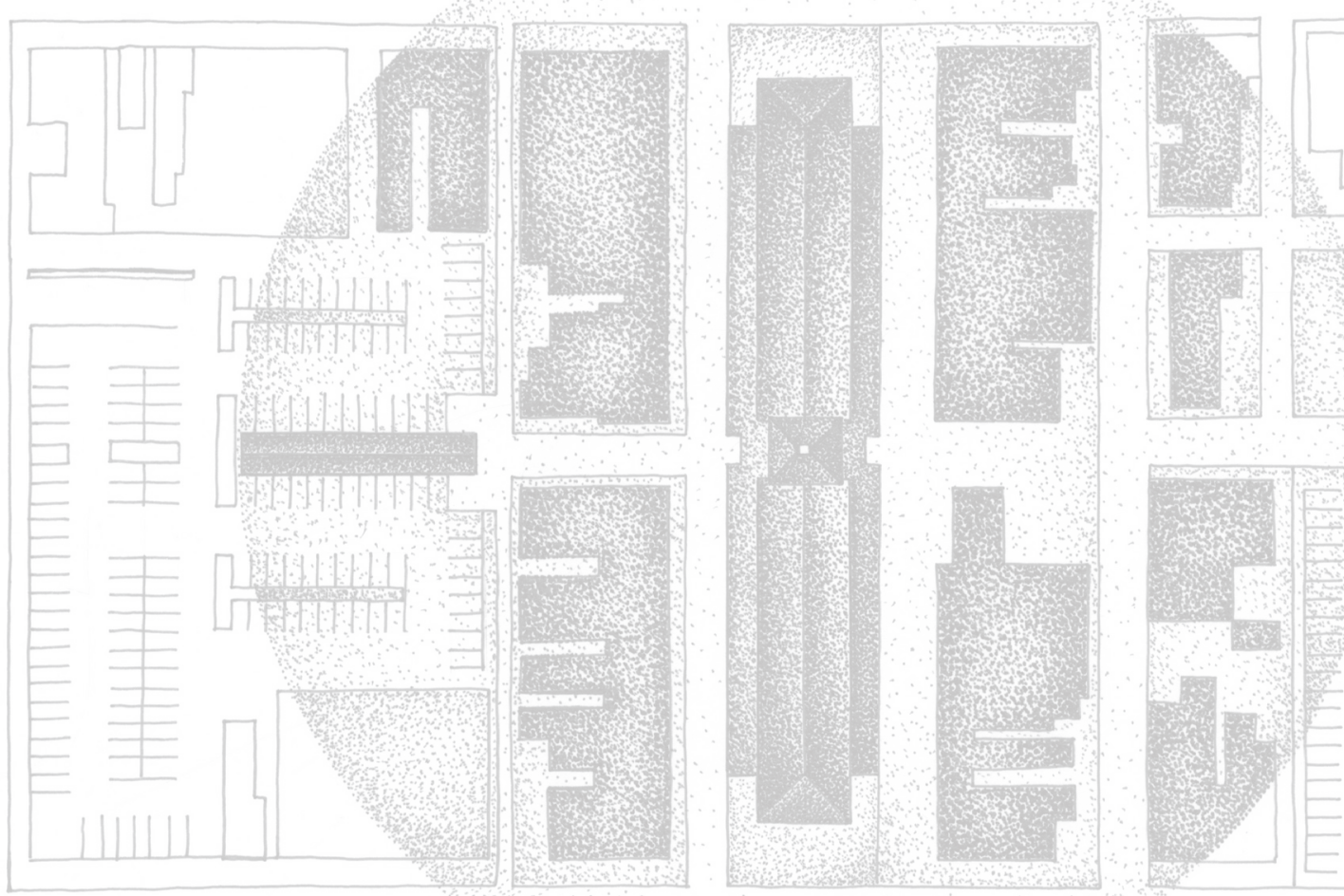


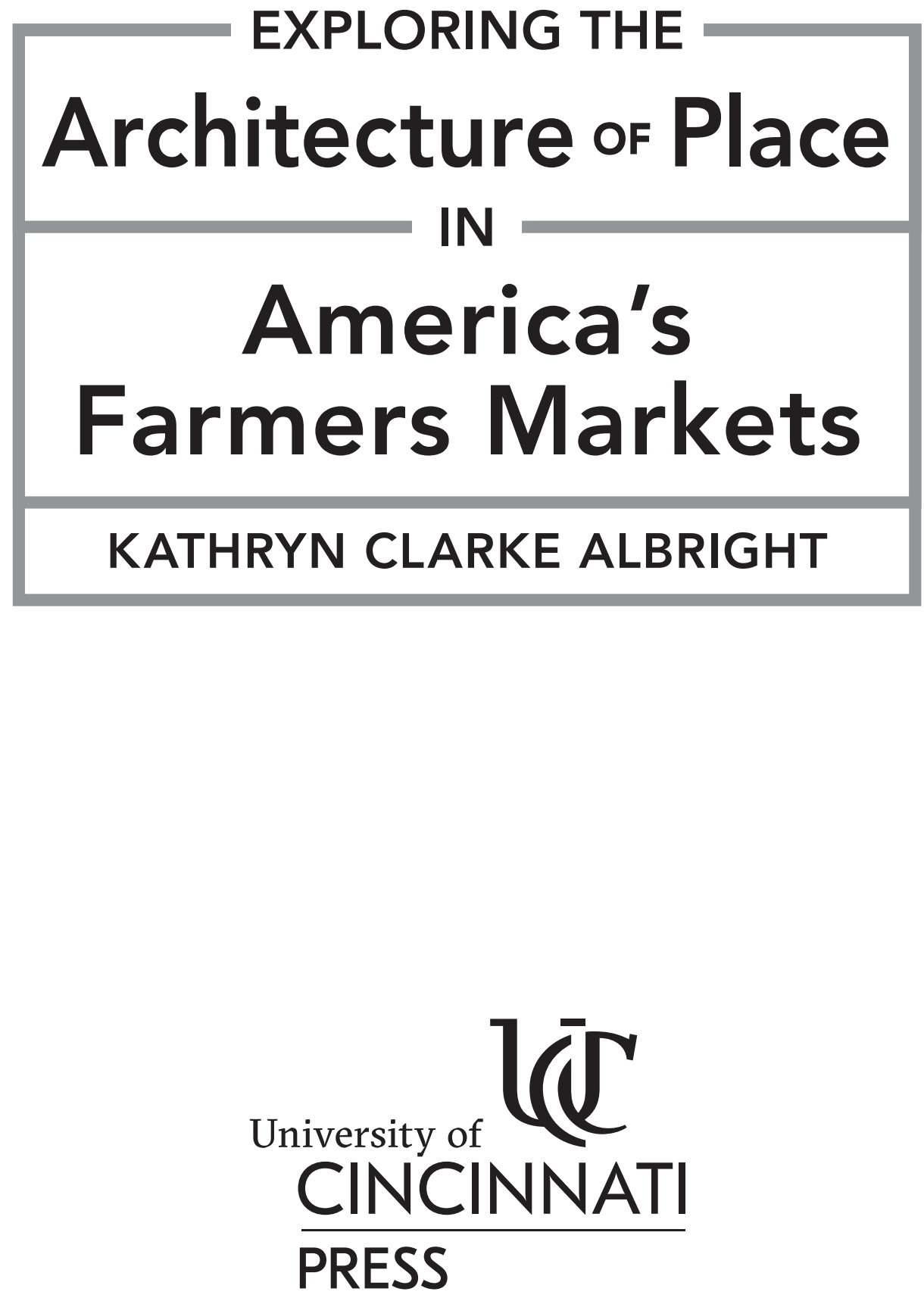

VIRGINIA TECH
In association with PUBLISHING 
The University of Cincinnati Press is committed to publishing rigorous, peerreviewed, leading scholarship accessibly to stimulate dialog among the academy, public intellectuals and lay practitioners. The Press endeavors to erase disciplinary boundaries in order to cast fresh light on common problems in our global community. Building on the university's long- standing tradition of social responsibility to the citizens of Cincinnati, state of Ohio, and the world, the Press publishes books on topics that expose and resolve disparities at every level of society and have local, national and global impact.

\section{The University of Cincinnati Press Copyright (C) 2020}

\section{(c) (P)}

This book is freely available in an open access edition thanks to TOME (Toward an Open Monograph Ecosystem)-a collaboration of the Association of American Universities, the Association of University Presses, and the Association of Research Libraries-and the generous support of Virginia Tech University. Learn more at the TOME website, available at: openmonographs.org. Requests regarding this work should be sent to University of Cincinnati Press, Langsam Library, 29II Woodside Drive, Cincinnati, Ohio 4522I

\section{ucincinnatipress.uc.edu}

Published in 2020

ISBN 978-г-947602-49-6 (EPUB) | ISBN 978-г-9476o2-50-2 (e-book, PDF)

ISBN 978-I-947602-66-3 (paperback)

An enhanced open-access edition of this book is available at https://ucincinnatipress.

manifoldapp.org/projects/exploring-the-architecture-of-place-in-america-s-farmers-markets

Albright, Kathryn Clarke, author.

Exploring the architecture of place in America's farmers markets

/ Kathryn Clarke Albright.

Cincinnati, Ohio: University of Cincinnati Press, 2020. | Includes bibliographical references and index.

LCCN 2019о2о849| ISBN 978г9476о2663 (paperback) | ISBN 978r947602496 (ebook, epub)

LCSH: Marketplaces--United States. | Farmers' markets--United States. | Architecture and society-United States. | BISAC: ARCHITECTURE / General. | ARCHITECTURE / Urban \& Land Use Planning. | ARCHITECTURE / Sustainability \& Green Design.

LCG NA9o68. A43 2020 | DDC 720.I/o3--dc23 LC record available at https://lccn.loc.gov/20rgo2o849

\section{ON THE COVER:}

Image of diagram showing 5oo-foot radius of Market District courtesy of Alireza Borhani Haghighi. Copyright (C) 2019 by Alireza Borhani Haghighi

Photograph of Charlottesville City Market courtesy of Charlottesville Park and Recreation

Designed and produced for UC Press by Alisa Strauss

Typeset in: Avenir and Baskerville I20 Pro

Printed in the United States of America

First Printing

For accreditation of individual images,

see image credits in the back of the book.

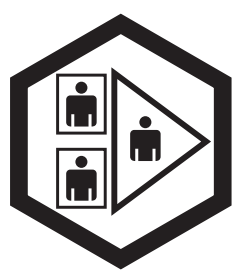




\section{TABLE OF CONTENTS}

Preface

vii

Introduction Meet Me at the Farmers Market

3

Chapter 1 Food with a Face

21

Chapter 2 Heritage Building Markets

Chapter 3 Open-Air Pavilion Markets

65

Chapter 4 Pop-Up Canopy Markets

Chapter 5 Mobile Markets \& Urban Farms

Conclusion A Sense of Place, A Sense of Time

Notes

Image Credits

Works Cited

Suggested Readings

Websites Cited

Index

Author Bio 
For Fohn Henderson Albright (r95o - 2019) husband, architect, wood crafter, farmers market vendor, and much more, whose endless support nurtured this book in many ways 


\section{PREFACE}

T BEGAN THINKING ABOUT the architecture of community gathering places when I lived and worked in the Bay area in the late ig8os. As an architect I was involved with several urban design projects, including one in San Jose in the area known as Communications Hill. The city of San Jose was considering annexing Communications Hill in order to turn the land (more than 300 acres) into new mixed-use neighborhoods. During the planning process I thought a lot about how to incorporate community gathering places into the neighborhoods. It occurred to me at the time that community spaces were becoming afterthoughts in much urban planning, except perhaps in private development where the spaces were accessible only to those people living or working there. It also seemed to me that many of the community gathering places that did exist were not necessarily working in the way the designers had envisioned, as evidenced by the fact that they were frequently empty.

I moved to Blacksburg, VA, in the mid-Ig9os and several years later had become a regular at my hometown farmers market. I couldn't help noticing how the market served as a public gathering place for the community, but felt it did not fulfill its full potential. People lingered 


\section{Preface}

after making purchases, chatting with fellow shoppers or vendors, but there was no place to sit and enjoy the bustle of the market or a relaxed chat with friends. This experience started what has become for me an ongoing fascination with public and farmers markets across the country. As an architect, I am particularly drawn to the design elements that make these spaces magnets for their communities. At the time I did not realize that these markets were booming throughout the United States. According to the USDA National Farmers Market Directory, the number of markets in the U.S. has grown dramatically between 1994 and 20I9, from roughly I,755 to over 8,700 markets, an astounding 397 percent increase. This certainly piqued my curiosity. How much of this resurgence, I wondered, had to do with the desire to buy fresh healthy food, and how much of it had to do with a longing for a sense of community and face-to-face interaction in an architectural place?

My thinking about the architecture of place has been greatly influenced by the book Chambers for a Memory Palace (1994) by Donlyn Lyndon and Charles Moore. The book is an exchange of letters between the authors, both architects, in which they discuss a wonderfully eclectic set of buildings, gardens, and monuments from around the world-the Taj Mahal, Mosque of Cordoba, Beverly Hills Civic Center, et al. What ties all of these places together for Lyndon and Moore is a common set of architectural elements, elements that give each space a sense of place. They use terms such as "walls that layer," "openings that frame," "roofs that encompass," and "niches that embrace." In one sense, these elements are present in architecture everywhere, but they manifest themselves differently in different places. Ever since I read Chambers for a Memory Palace I've watched for these elements when I visit someplace new, so it is not surprising that I've incorporated them into my thinking. In fact, they are key to three of the typologies of markets I identify and explore in this book-heritage building, open-air pavilion, and pop-up canopy.

Additional popular books by Jane Jacobs and William H. (Holly) White informed how I observed these markets. In Death and Life of Great American Cities (196r) Jacobs discusses at length the importance of a sense of community for neighborhood vitality and encourages every resident to keep "eyes on the streets" as a way to participate in public spaces. In White's book, The Social Life of Small Urban Places (ig8o), he discusses necessary elements for engaging people (particularly places for 
people to sit) in public places, including streets, plazas, parks, and civic squares. White's work has been influential for the nonprofit organization Project for Public Spaces' (PPS) multi-faceted urban endeavors since its inception in 1975 .

PPS has been supporting communities that want to rejuvenate existing public spaces or to create new ones for over forty years. Their work has been persuasive among architects like me, encouraging us to think in new ways about the notion of "placemaking," which PPS defines as people working collaboratively to improve public spaces for the benefit of everyone in the community. Over the years PPS has played a role in community development projects in Boston (Boston Public Market), Detroit (Campus Martius Park), Fort Worth (Sundance Square), New York City (Bryant Park) and many more. PPS has also published a number of influential books and reports, including Public Markets and Community Revitalization (1984), How To Turn a Place Around (2000), and The Case for Healthy Places (2016), some of which can be downloaded for free from the PPS website.

I bring to this book my own unique perspective as a teacher and practicing architect. I have also been involved with my own local farmers market. In 200I I founded Friends of the Farmers Market, which led to the opening of a new farmers market pavilion in Blacksburg's new Market Square Park in 2009. Over the years my travels have taken me to all of the markets I discuss in the book and many more (Seattle's Pike Place, San Francisco's Ferry Plaza, Albuquerque's Downtown Growers, and Boston's Copley Square, to name a few) that I do not discuss. The ones I chose to include are markets that are part of my life's routine, whether shopping in my hometown market in Blacksburg or in Washington, D.C., or taking students to Cincinnati or Charlottesville to study the city's architecture. They span the gamut from classic market buildings to temporary assemblages of pop-up canopies that can be found all across our country. A key point I want to emphasize is that even the humblest of markets, in edifice style and size, perform as places for community gathering and civic engagement through the architecture of place they make. It is my hope that readers will feel as though they are with me as I tell the stories of a few markets in Ohio, Virginia, North Carolina, and the District of Columbia. Perhaps I will even inspire them to look at their own markets with fresh eyes. 


\section{Preface}

I also want readers to think about what lies ahead. I conclude the book with a broad look at the way of life and living that farmers markets have spawned, while looking forward to what I see as an emerging new typology -the mobile market- which takes the bounty of local farmers to neighborhoods underserved with fresh healthy food-otherwise known as food deserts. Market vendors speak enthusiastically about the qualitative benefits that farming life allows, and the greater good their individual choice provides for the general public and region. I unexpectedly found out that people with limited incomes who receive federal Supplemental Nutrition Assistance Program (SNAP) benefits can redeem them at most farmers markets. Both the mobile market and SNAP acceptance at farmers markets make fresh food access more equitable. Finally, an array of governmental, commerce, and community leaders champion the economic development farmers markets catalyze through allied business development and civic commitment. The impact of these markets on local economies can be significant, generating not just income for farmers but also tax revenues for communities. Similarly, it is estimated that growers selling locally generate four times as many jobs as those who sell beyond their region. All in all, I hope readers will come to appreciate how multidimensional farmers markets are. 
EXPLORING THE

Architecture of Place

IN

$$
\text { America's }
$$

Farmers Markets 



\section{INTRODUCTION}

\section{MEET ME AT THE FARMERS MARKET}

NE BRIGHT SUNNy Saturday in September I was traveling with students in Cincinnati to explore its contemporary architecture. After lunch I had a chance to walk over to the city's marvelous Findlay Market located in the historic Over-the-Rhine neighborhood. Findlay is one of the oldest and most beloved city markets in America. As I approached the market building entrance plaza from Race Street, I had to weave my way through massive three-foot-tall pots overflowing with flowers and red metal tables surrounded by groups of people absorbed in conversation. Off to the side I saw metal racks nearly filled with bicycles of all types and sizes. The scene reminded me of a bumper sticker I once saw that read, "Meet Me at the Farmers Market."

Standing in front of the two-story portico entrance, I took in the rainbow of painted colors before me - the lavender columns, the orange window frames, the red door frames with green surrounds, and the market sign, orange with "Findlay Market" in blue letters and a red tomato at the center. Peering through the glass doors I saw the interior market hall filled with shoppers looking into glass cases filled with fresh cheeses, meats, poultry, and baked goods. Then looking overhead, I saw a banner directing people to the opposite end of the market, to 


\section{Introduction}

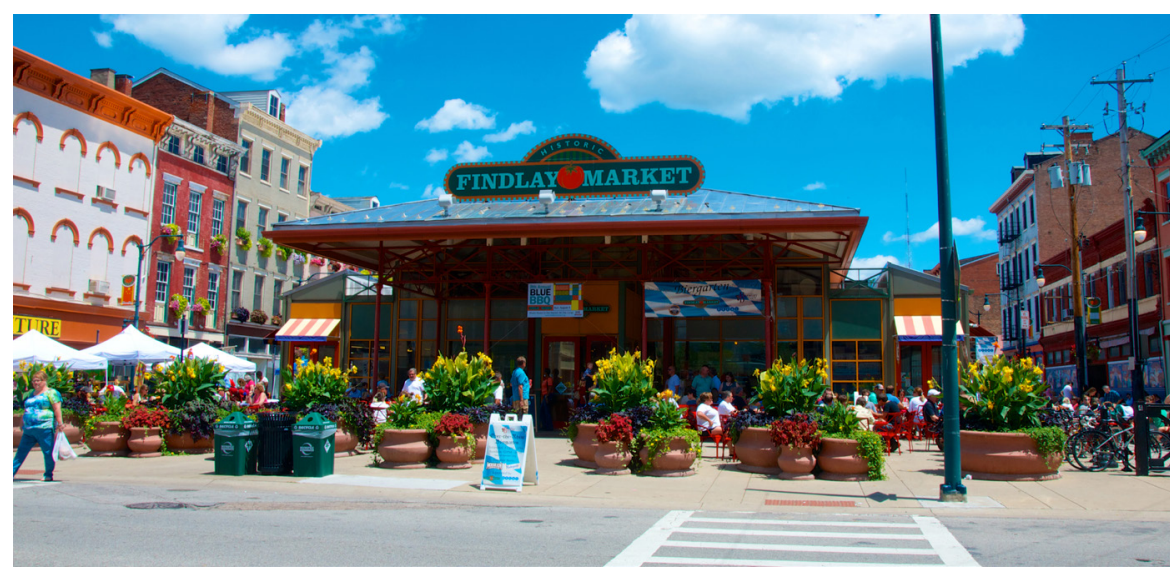

Image 0.1 Findlay Market's Race Street entrance.

Findlay's Biergarten on the Elm Street esplanade. I headed that way, turning down Elder Street, which is lined with a variety of vendor stalls spilling out into the street. I was struck by the sense of spatial intimacy created by crowds of shoppers wandering through the stalls, stopping at times to talk with or buy from vendors. Finally arriving at the Biergarten, I settled in with a pint of local beer to relax and people-watch. Findlay Market is precisely what one regional tourism website calls it, a place to be part of a "quintessentially urban shopping experience" (see image o.I).

Through my journeys across our country visiting a spectrum of farmers markets, I've learned that all markets have their own distinct character that makes them unique to their own communities. For instance, the Charleston (SC) Farmers Market is a temporary market that began in rg89 with the support of the Clemson University Cooperative Extension Service. On Saturdays, Lowcountry farmers and artisans set up their tables and canopies amid the trees around the perimeter of Marion Square with goods that make a community connection to its regional heritage. However, in Lancaster, PA, the historic Central Market with its Romanesque Revival architecture (late i8oos) provides the unique character for this community gathering place in Penn Square.

Despite the obvious diversity among the many markets that I've visited over the years, I have found three distinct architectural types that appear again and again across the country. I call the three types heritage building, open-air pavilion, and pop-up canopy. In addition, I've identified 


\section{Meet $\mathrm{Me}$ at the Farmers Market}

a newly emerging type of market that I call the mobile market. In this book I take a closer look at all four types of markets, paying special attention to their architectural features, whether the markets are made up of monumental buildings, simple structures, or transportable assemblies. I am also very interested in the specific local context in which the buildings are situated, because there is a unique spatial relationship between buildings and their locales that shapes the experiences of all of those who gather at markets and make them truly function as places for community gathering and civic engagement.

This brings me to a point about terminology. Markets for farmers to directly sell their harvest to local urban communities are deeply rooted in American history and culture. In the early republic such markets, which at the time were called public markets, typically operated under the oversight of the local government, which assured fair sales and sanitary practices to ensure abundance of nonspoiled food. Over time, it became increasingly common for nonfarming vendors to join farmers as vendors at these markets. The new vendors practiced what is known as "resale," which involves purchasing fresh food from local farmers or from wholesale merchants that could bring produce to market from local or even distant farms. In other words, not all vendors would necessarily grow, raise, or otherwise make the food products they sell. This distinction has led some to differentiate between farmers markets (places for local farmers to sell their harvest) and public markets (places for both farmers and vendors who practice resale).

Today, however, the line between farmers markets and public markets has blurred considerably, and it is common to find resale vendors at both types, depending on each market's regulations. For example, the original nineteenth-century building at Findlay Market is where farmers from the region around Cincinnati would come to sell their harvest. Today most of the vendors in the building are not selling food and goods they have grown, raised, or made. To further complicate things, midway down Elder Street there is a heavy timber pavilion, referred to locally as the Farmers Market, where local farmers sell their produce and fresh foods. In addition, along one side of Elder Street there are pop-up canopy vendors selling fresh foods and handmade crafts from various origins.

Given the increasingly fuzzy line between farmers markets and public markets, I will mostly use the term farmers markets throughout 


\section{Introduction}

this book, and occasionally I may use the two terms interchangeably. This is not to say that public and farmers markets are always the same, but for my purposes the distinction is not important in discussing typologies and how they relate to the making of an architecture of place.

A number of factors contribute to whether or not a market is successful in a community. One of these is location. Is the market positioned well in a town or city so that people are motivated to visit it? The heritage market building serves as a landmark, a familiar reference point when finding one's place in a neighborhood. In addition to Cincinnati's Findlay Market, Eastern Market in Washington, DC, and Reading Terminal Market in Philadelphia are two remaining heritage markets. Varying in size, multiple-purpose pavilions often coexist where urban development engages with the natural landscape, most often in a public park. In cities such as Durham, NC, and Little Rock, AR, open-air pavilions have assisted in revitalization at the core of the city. Pop-up canopy markets are the most adaptive, sprouting up in a parking lot or even a wide street in a historic district.

Architecture and urban design are also important. What I have learned over the years is that markets originate and persist where elements of architecture (columns, thresholds, archways, windows, floors, and roofs) combine with circumstances of an urban setting (surrounding buildings, plazas, sidewalks, parking, transit access, and topography) to create welcoming places where people with shared interests come together for economic and social exchange.

For the featured markets' stories, I defined eight scales using architectural elements combined with urban circumstances that give identity to each market while fostering interaction between vendors, shoppers, and the community at large (see image o.2). The scales of interaction and interface include: (I) hand, (2) container, (3) person, (4) individual vendor stall, (5) group of stalls, (6) street, (7) block, and (8) a market's situation within a town and region. Each of these scales has a relationship to a physical dimension: a measure of length, width and/or height, or distance. From the scale of the hand to a display of goods and related exchange to a market's configuration within a neighborhood or district, the environment of farmers markets nurtures camaraderie through the shared experience and appreciation of obtaining local, fresh healthy food. In chapters that focus on three seminal types of markets, case 


\section{Meet Me at the Farmers Market}

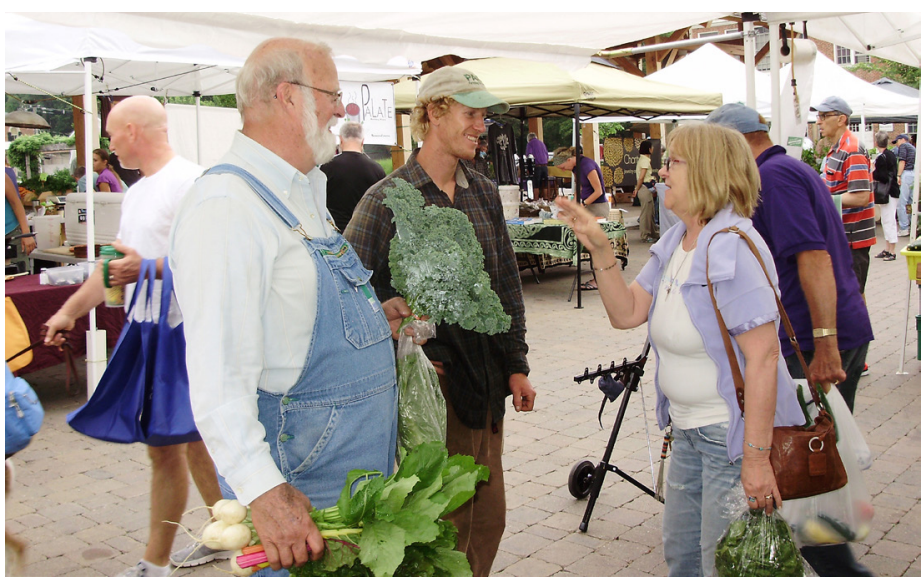

Image 0.2 Patrons talk with farmer Jason Pall (center).

studies of farmers markets that I visited within the United States provide tangible understanding of architectural elements and relationships as well as spatial urban conditions at the eight scales listed above.

Our hands can grasp with ease an array of food items up to twelve inches (see image o.3). All types of markets share this scale of interaction, but each market has its own way of enticing shoppers to reach for and examine goods, whether fresh-grown produce or homemade items. At most markets, shoppers grab half-dozen radishes bundled with a rubber band around their tops without pause, but hesitate to pick up carrots with their long leafy greens attached and stacked high in a heap. From late July to early September, bright red, yellow, orange, and green

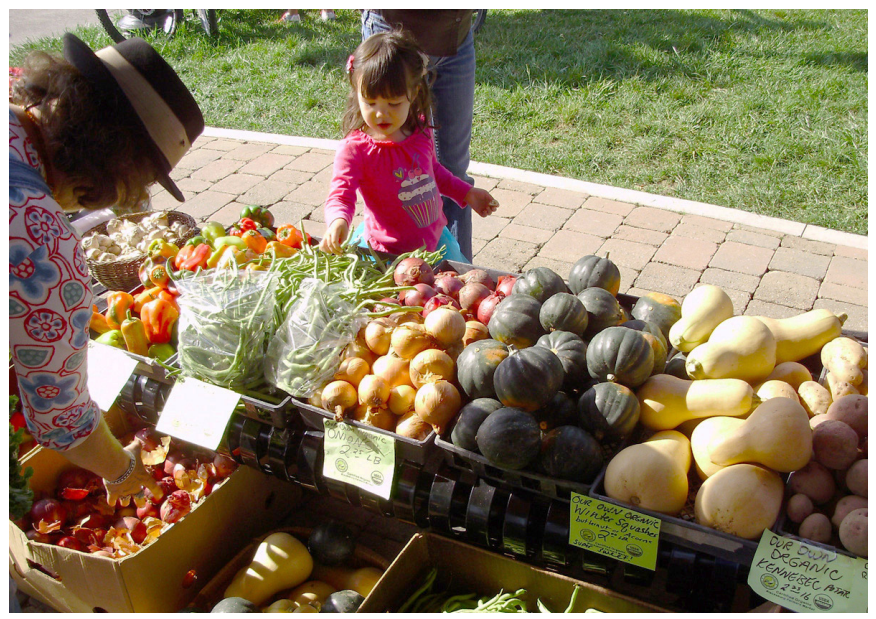

Image 0.3 Young girl cannot resist touching the green beans. 


\section{Introduction}

tomatoes laid bare on a table sparkle in the sunlight, radiate juiciness, and seduce shoppers to bring their hands to their noses for a sniff. Likewise, fresh young ginger alongside just-cut sprays of herbs dazzle the eyes and nose, while bushels of string beans spilling onto the table lure shoppers to grab a handful or two to purchase. It becomes important what kind of container the goods are presented in.

Vegetables, baked goods, and homemade items are displayed in boxes, baskets, and crates, all giving of an air of controlled disorder. Although varying in size and capacity, they tend toward a managed human scale of interface, a scale that generally ranges from four to twenty-four inches (see image 0.4). Although vendors often use the same or similar containers, each vendor has a unique identity based upon different placement and methods of display that serve to entice shoppers into the stall. Glass vases holding bouquets of seasonal flowers stand adjacent to stainless steel bowls overflowing with salad greens. Eight- to ten-inch woven baskets lined with colorful cloths and brimming with muffins, scones, and brownies sit beside twenty-ounce bottles of pink lemonade with blueberries. For a short time in the spring of each year at most markets, dozens of four-inch-square plastic mesh cartons filled with blueberries and strawberries glisten alongside pints of peppers. Some produce, like cucumbers, beans, and apples, are displayed in their containers of transport: the traditional eighteen-inch round wooden bushel, or the now-ubiquitous cardboard box measuring twelve by eighteen by eight inches (see image 0.5). A container's dimensions are inextricably linked to the scale of a person, the measure of the body.

The height of the average human is between five and six feet. This is the most important dimension for establishing the scale of a farmers market (see image o.6). Of course, there are many children of shorter height and numerous people over six feet tall at markets, but it is adults that typically make the purchases, so markets are designed to entice them as buyers. Also included in this scale of interface and interaction are tables, chairs, shelves, umbrellas, benches, banners, and any other items that support the display, purchase of food and handmade goods, and transport to and from the market (see image 0.7). The scale of an adult unites the parts to the whole within the market itself and beyond its situation in the town or city (what I call the district scale), as people travel to and from the market by walking some portion of their journey. 
Meet $\mathrm{Me}$ at the Farmers Market

Image 0.4 Bountiful baskets display fresh seasonal harvest.

Image 0.5 Boxes as display container for apples.
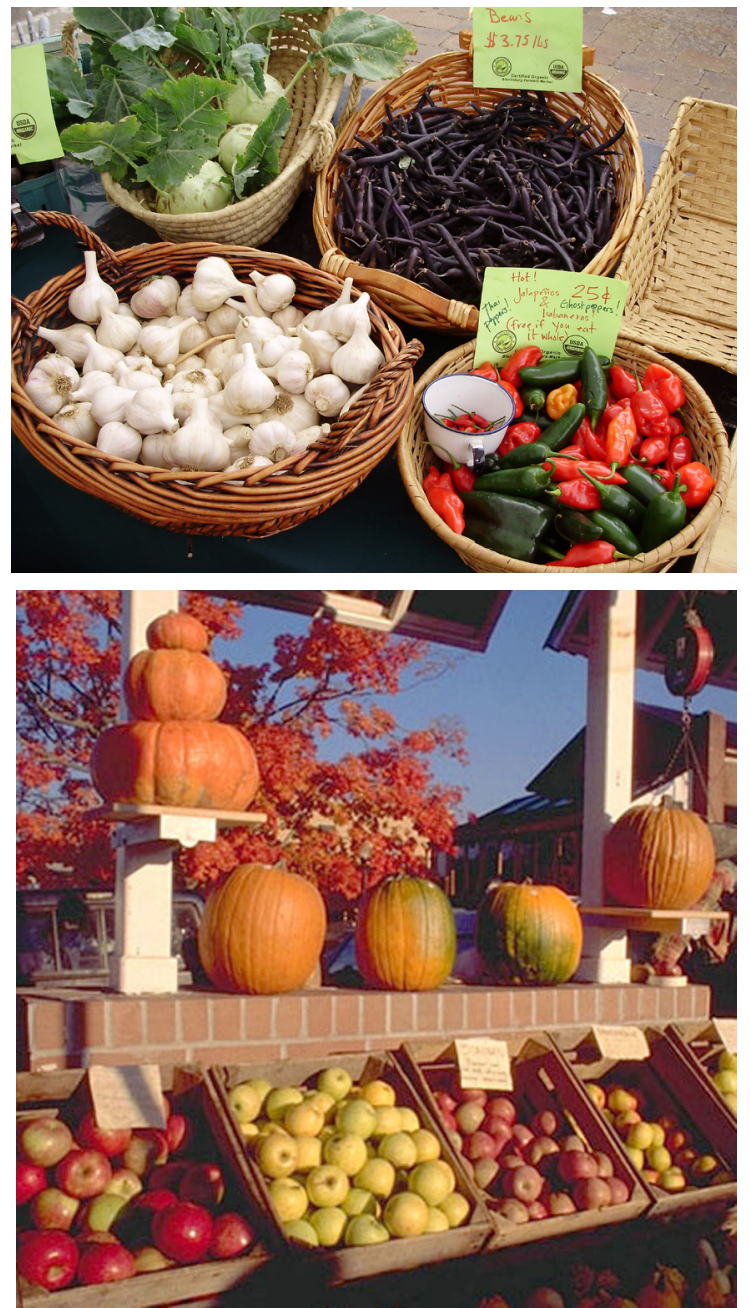

Image 0.6 Yellow plastic tubs as display containers for an array of vegetables.

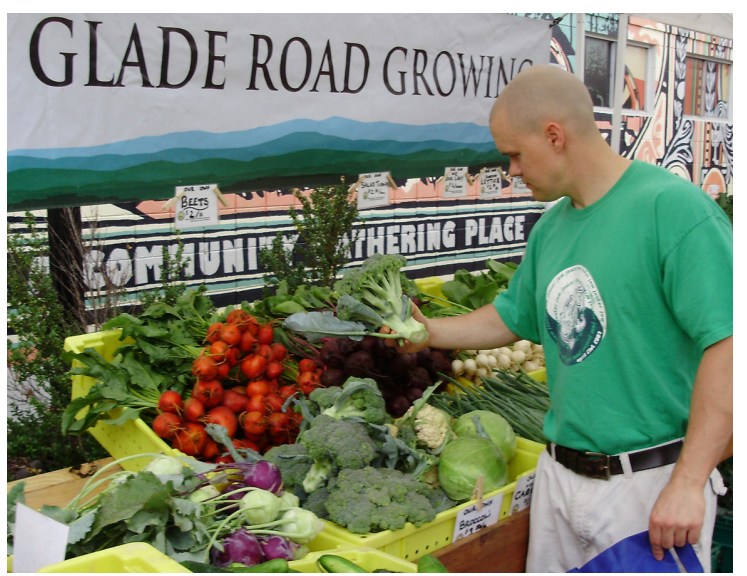


Introduction

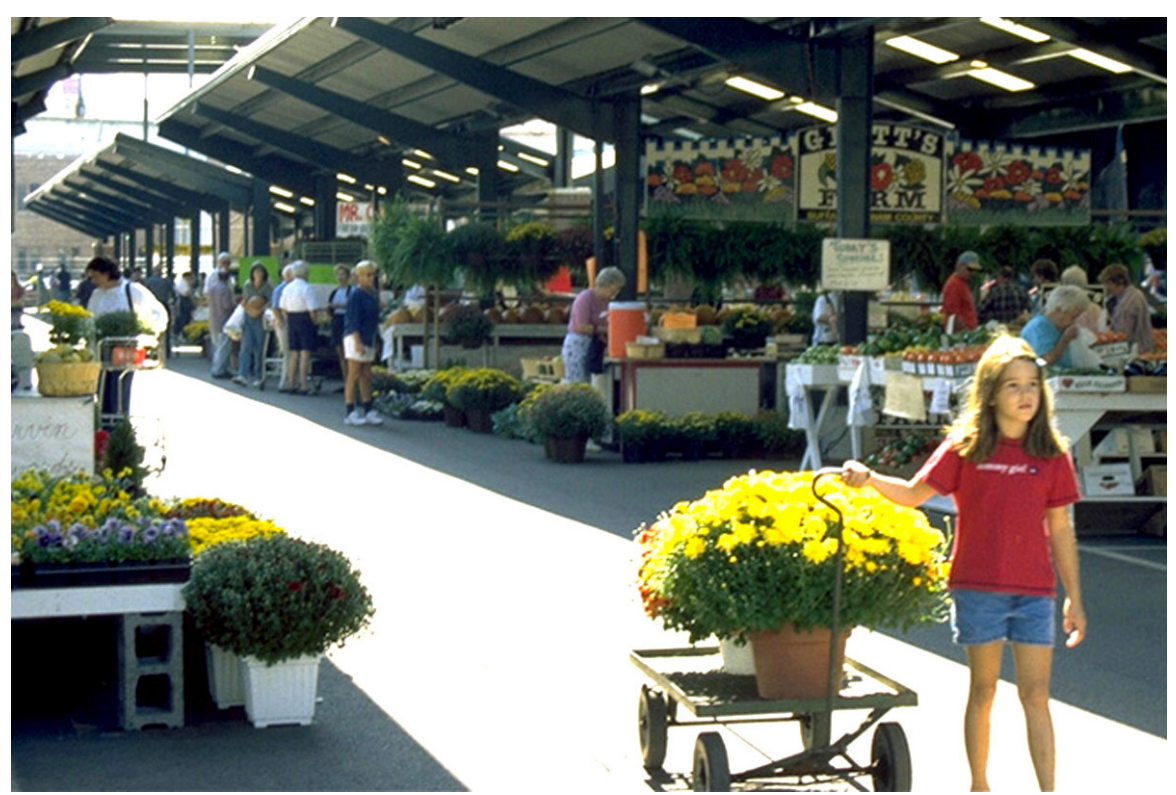

Image 0.7 Young girl hauls away her flowers on cart at Charleston's Capitol Market.

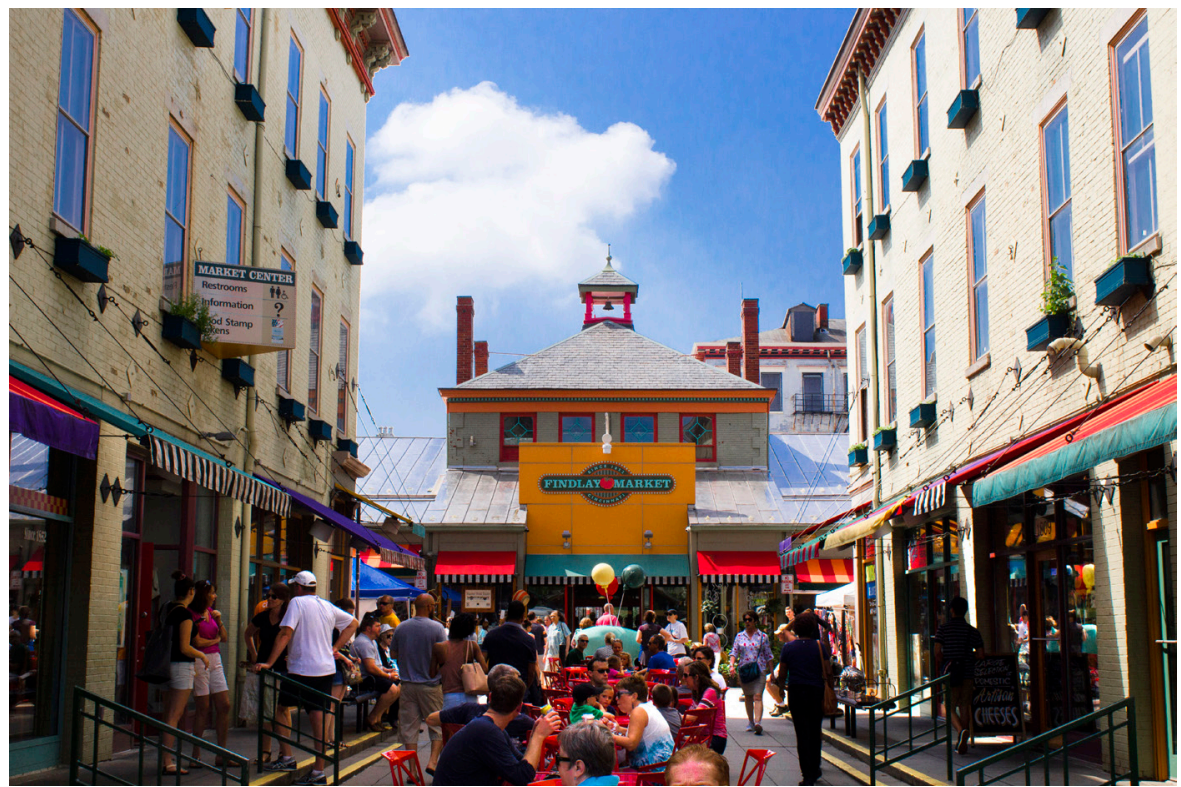

Image 0.8 New stalls encompass the perimeter of Cincinnati's renovated Findlay Market. 


\section{Meet $\mathrm{Me}$ at the Farmers Market}

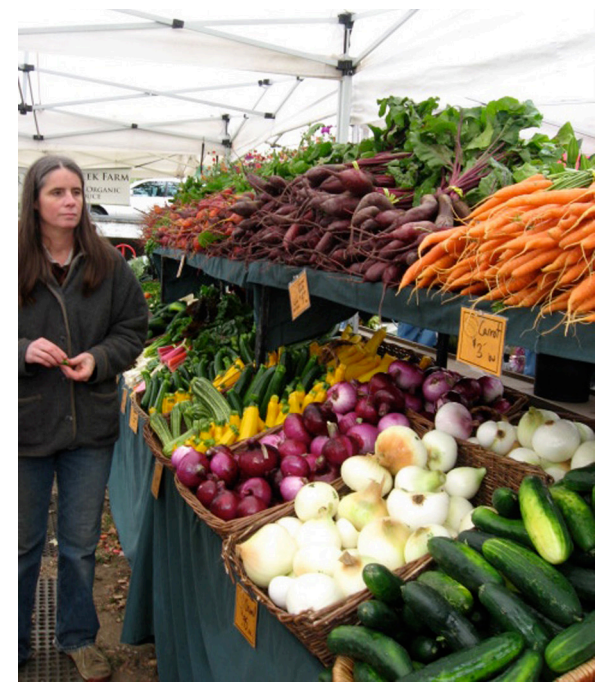

Image 0.9 Two-tier shelves showcase baskets and bundles of vegetables.

Sometimes, as is the case at Eastern Market in Washington, DC, the human scale stands in strong disparity to the building, which dwarfs the size of a person. Contrast this to Cincinnati's Findlay Market, where despite being nearly four hundred feet long, the market is comfortable at the scale of a person, thanks to variation in the size and frequency of its perimeter stalls (see image o.8).

The size of the typical stall varies from seven to twenty feet in width and five to twenty-five feet in depth; height is contextual and depends on the type of market: heritage building, open-air pavilion, or pop-up canopy. Often in a heritage building market, a vendor occupies two spaces. At pop-up canopy markets, the collapsible tent-like, fabric-roofed structure provides minimum boundary and shelter for a vendor's stall and on average covers an area of twelve square feet (see image o.9). Even more influential than the type of market in determining stall height is the configuration of tables and display of goods-which gives the vendor identity and therefore more often determines specific dimensions in this scale of interface (see images o.ro and o.II).

From my conversations with vendors and shoppers I learned that a grouping of at least a half-dozen vendors within an area of fifty to seventy-five feet constitutes a farmers market (see image o.r2). Pop-up canopy markets replicate this scale the closest; they are set up in public spaces and configured in various ways: linear, L-shaped, and U-shaped. Vendors at the North Union Farmers Market in Cleveland's historic Shaker 


\section{Introduction}
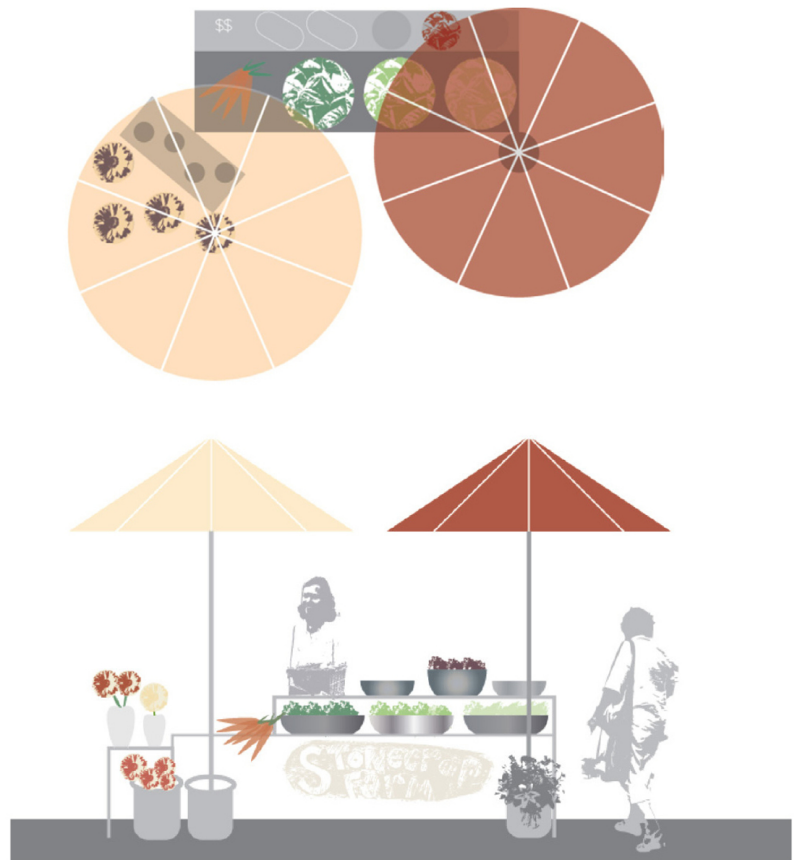

Image 0.10 Diagram of stall under umbrellas in plan (top) and elevation.

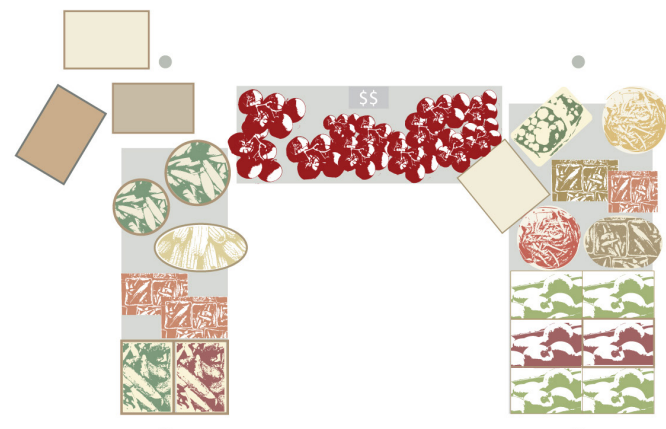

-

-

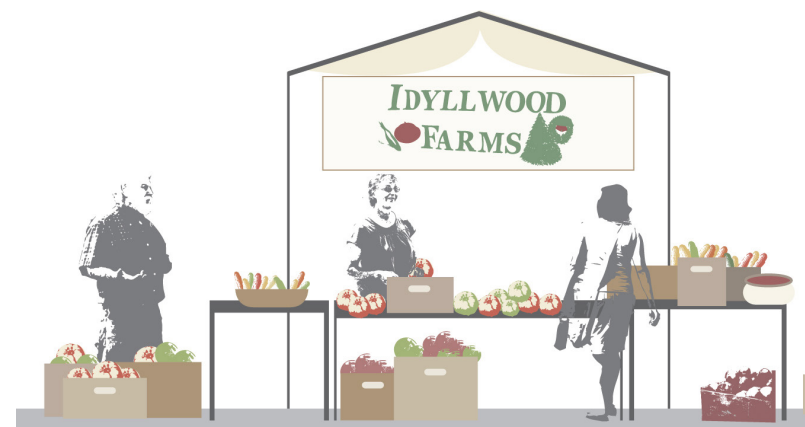

Image 0.11 Diagram of stall under tent in plan (top) and elevation. 


\section{Introduction}

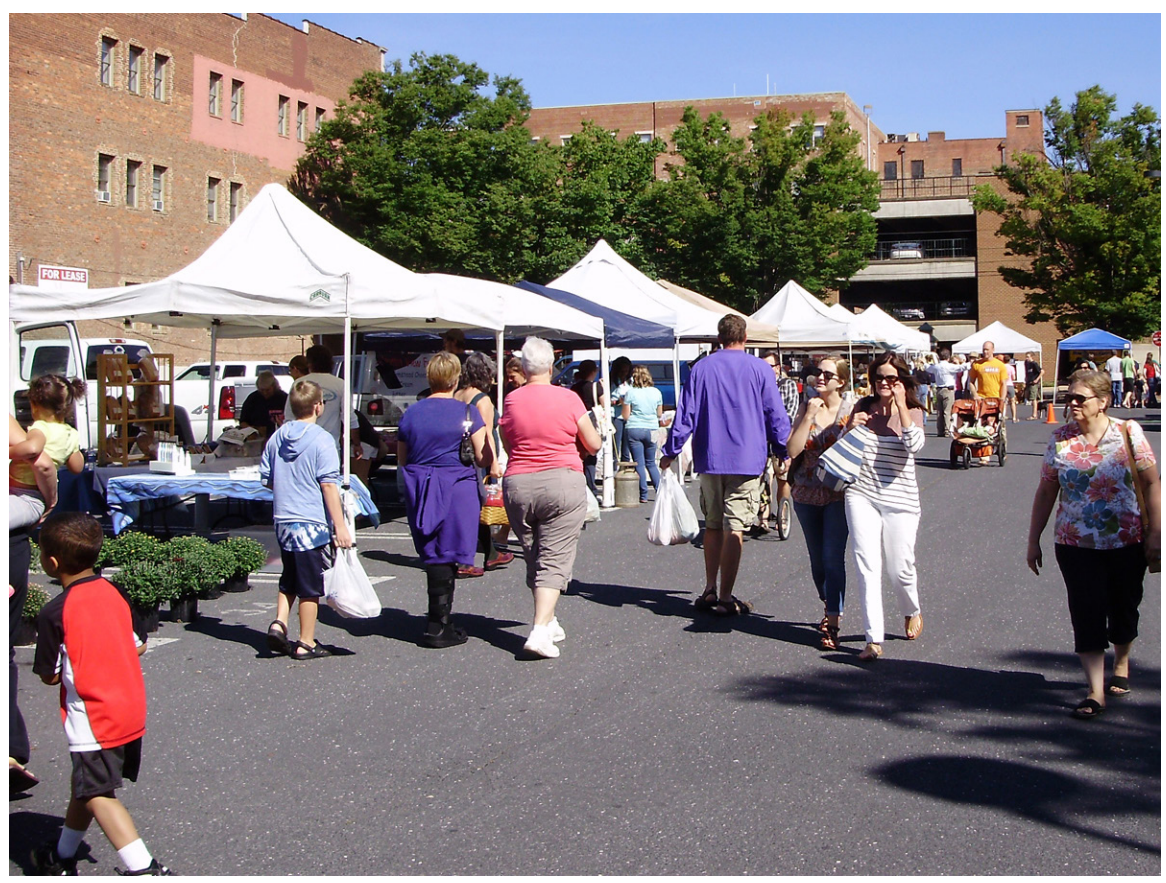

Image 0.12 Pop-up canopies in parking lot in Staunton, Virginia.

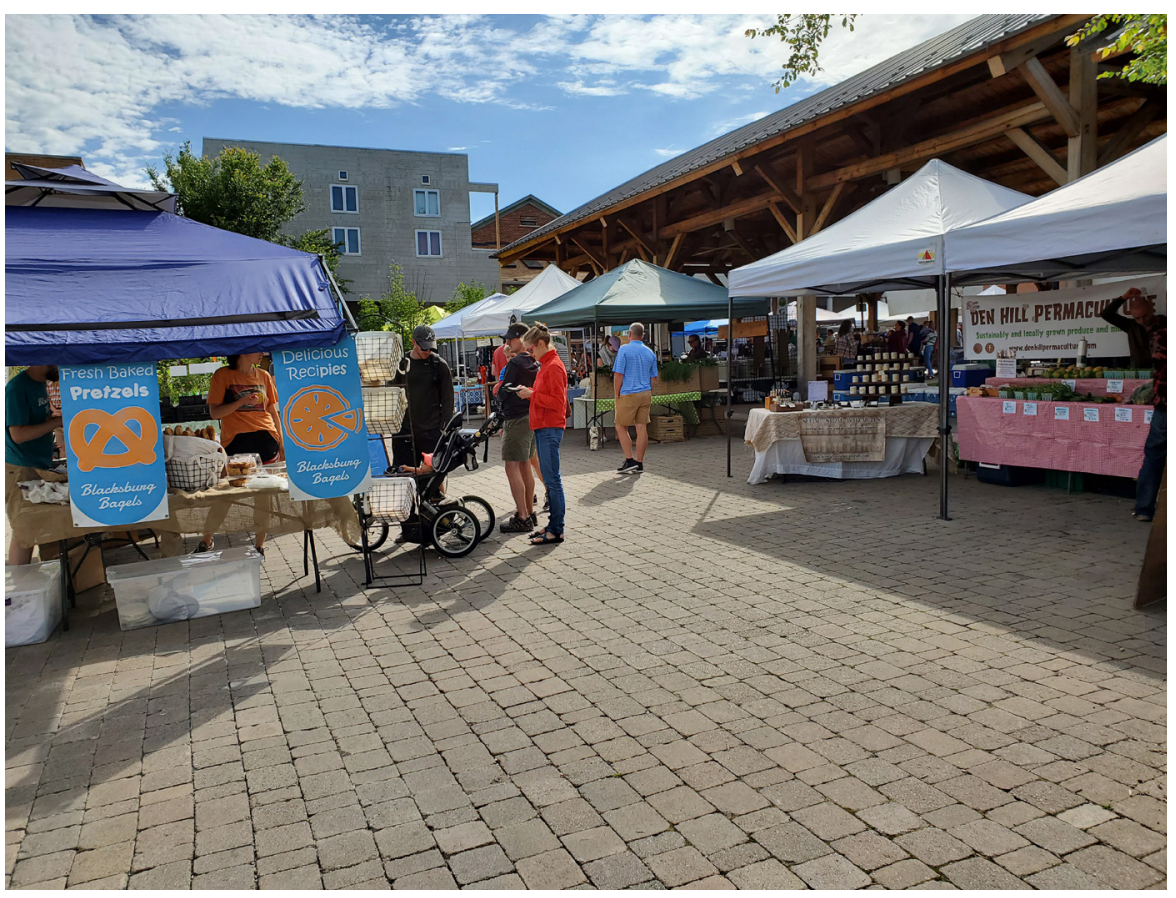

Image 0.13 Canopies adjacent to pavilion at Blacksburg Farmers Market. 


\section{Meet Me at the Farmers Market}

Square first set up their canopies in 1995 with only six vendors lined up adjacent to a commuter train stop; today, the market boasts eighty vendors. The market is comprised of two rows of canopies on both sides of the rail and overflows with people who momentarily pause each time the commuter train stops. However, I have also observed that pop-up canopy vendors selling specialty items, such as crafts or food prepared on site, often situate themselves adjacent to heritage building and openair pavilion markets. Such is the case at my hometown market, which has expanded beyond twenty spaces under its pavilion to include at least twenty additional canopies set up on the cobblestones adjacent to the open-air structure (see image o.r3).

Some markets are associated with adjacent businesses, as the ground floor activity of each supports the other. Pedestrian activity is a constituent part of any place that thrives on community gathering and civic engagement. Close proximity to adjacent businesses is tantamount to convenience-a necessity of everyday life that, if capitalized on, can be extremely beneficial for markets. I define a market as in close proximity to an adjacent business if the cross section of a street includes both at a distance of no more than roo feet. One of the most distinctive examples of a market's close proximity to adjacent businesses is Roanoke, Virginia's farmers market, where vendors' narrow tables covered by fabric canopies cover two blocks squeezed between parking spaces and the sidewalk lined with storefronts (see image o.I4).

It is not unusual for a market to take up an entire block. Blocks vary in size: Blacksburg historic blocks are on average 265 feet by 300 feet, Roanoke's are bit longer. Heritage building markets typically cover most of a block, while open-air pavilion markets are situated within a block. All markets rely on the surrounding district, neighborhood, or region-usually identified as an area within a quarter-mile or a fifteen-minute walking distance. Other markets extend their accessibility to customers by taking advantage of multiple transportation access modes. While markets depend on their location for their livelihood, they can also assist in renewal of the neighborhoods that support them. Cleveland's West Side Market is a case in point.

Cleveland's heritage building market was built in 1912 in the heart of the bustling Ohio City neighborhood across the river from downtown (see image 0.I5). It became accessible to more customers in 1955 when 


\section{Introduction}

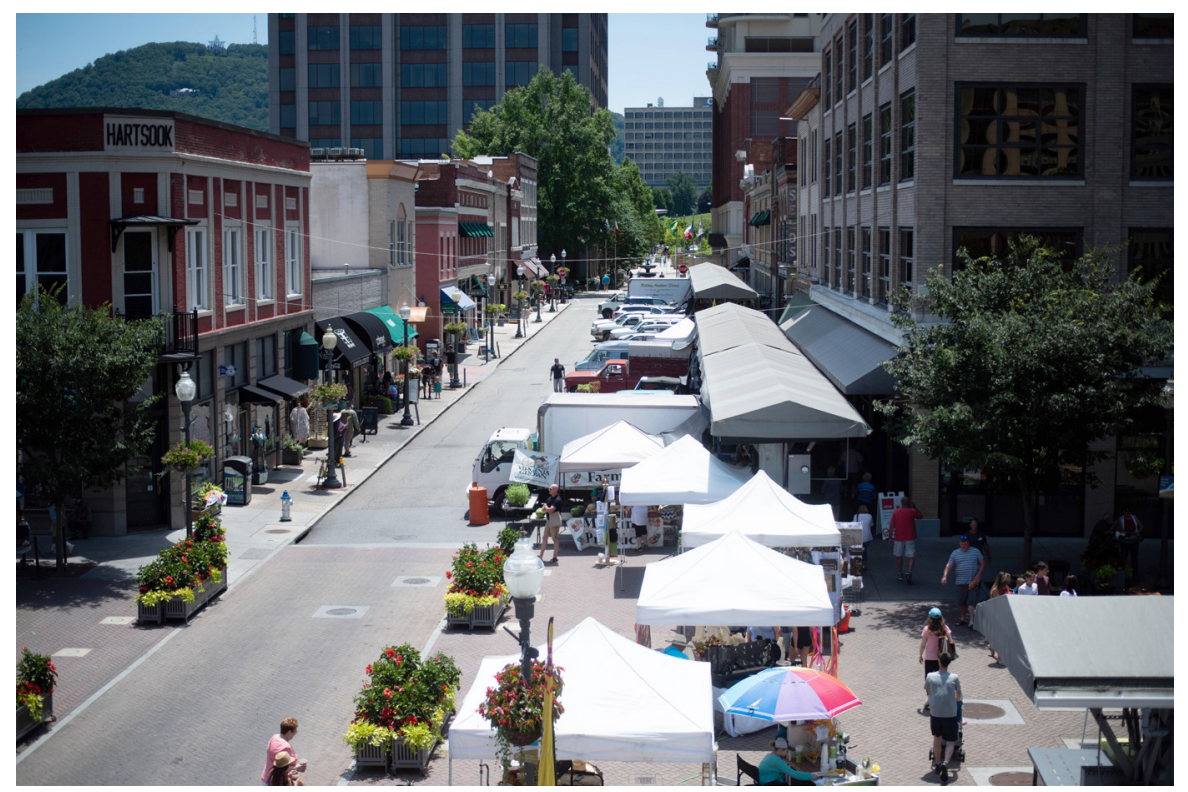

Image 0.14 Gray fabric covers the farmers market in Roanoke, Virginia.

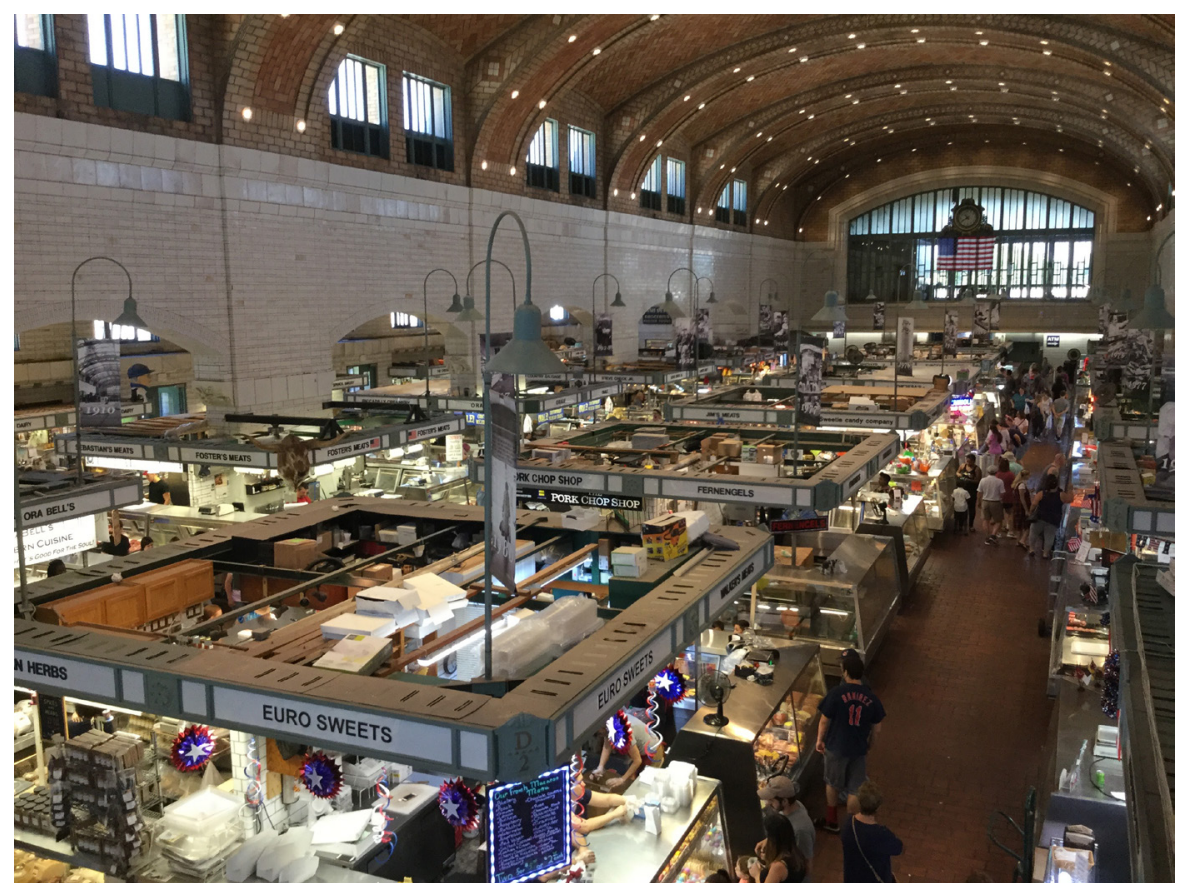

Image 0.15 Inside Cleveland's West Side Market. 


\section{Meet $\mathrm{Me}$ at the Farmers Market}

Cleveland extended its Rapid Transit Red Line and located the first stop just two blocks from the market. More recently, it was a \$2.6 million renovation of the original utilitarian station in 1992 that spawned the architectural refurbishing of West Side Market a decade later. Both stimulated the arrival of new businesses that renovated adjacent buildings and now provide an array of goods and services for residents; the Ohio City neighborhood is once again thriving, as it was at the turn of the twentieth century.

Farmers markets have historically played a significant role as one of handful of key civic institutions in a town or city. Indeed, many American cities were built around their public markets. Several of these markets that began with the founding of a city continue in their role as community gathering places today. Pierre L'Enfant's i79I plan for Washington, D.C., included multiple parcels designated for farmers markets. One these markets remains today: Eastern Market, which is one of the markets I explore in the heritage building markets chapter. In the I730 town plan for Lancaster, PA, James Hamilton laid out the town and gave sites for three public places- a jail, a courthouse, and a market house. ${ }^{\mathrm{I}}$

In Celebration, FL, planners made the farmers market a centerpiece of its new town development plan. In doing so, they were drawing upon the principles of "New Urbanism," an urban design and planning movement that started in the late rg8os. Built in 1994, Celebration's farmers market remains vibrant today as vendors set up adjacent to Lakeside Park every Sunday. In recent decades, proponents of New Urbanism have proven instrumental in coaxing numerous municipalities to revise their zoning ordinances in order to mandate parks, plazas, and other public gathering places as part of new building plans and redevelopment. Farmers markets often thrive in these new civic spaces due to their ability to nurture a sense of community through daily and/or weekly routines of shared purpose and interaction.

The growth of farmers markets and renovation of public markets may also stem from a yearning for authentic experience, in contrast to a daily routine filled with simulation and virtual reality. People long for the kind of multilayered experience that farmers markets can offer: the capacity to sponsor personal interaction between shoppers and among vendors. People want to experience the intimacy of knowing the 


\section{Meet Me at the Farmers Market}

person who grew or made the items they purchase (see image o.r6). At the outset, the book explores farmers markets' role as environments that nurture fellowship and ritual. The significance of a market's location is evident in its capacity to serve as a gathering place, offer identity for its surroundings, and build a sense of community. I have found it a common belief among consumers and vendors alike that the market does not belong to its owners, or the city government, but to the people who shop there. ${ }^{2}$

From my personal experience and interviews with many shoppers, a market's lure is in the experience of fresh food by sight, smell, touch, and taste, as well as a feeling of camaraderie for producing and enjoying fresh food. The sensory experience of shopping in a market makes it impossible not to pick up a piece of fruit without sniffing its sweet fragrance. The luminosity of the colors makes everything irresistible. The surprise of a unique, authentic experience persists from a shopper's first visit to the weekly ritual. Describing the joy of shopping at Berkeley's Farmers Market, Alice Waters, acclaimed chef of Chez Panisse restaurant, asserts that "there are times of the year when we can hardly wait to go to the farmers market in anticipation of the treasures we will find there."3 The market's ability to offer uniqueness lies in its ever-changing
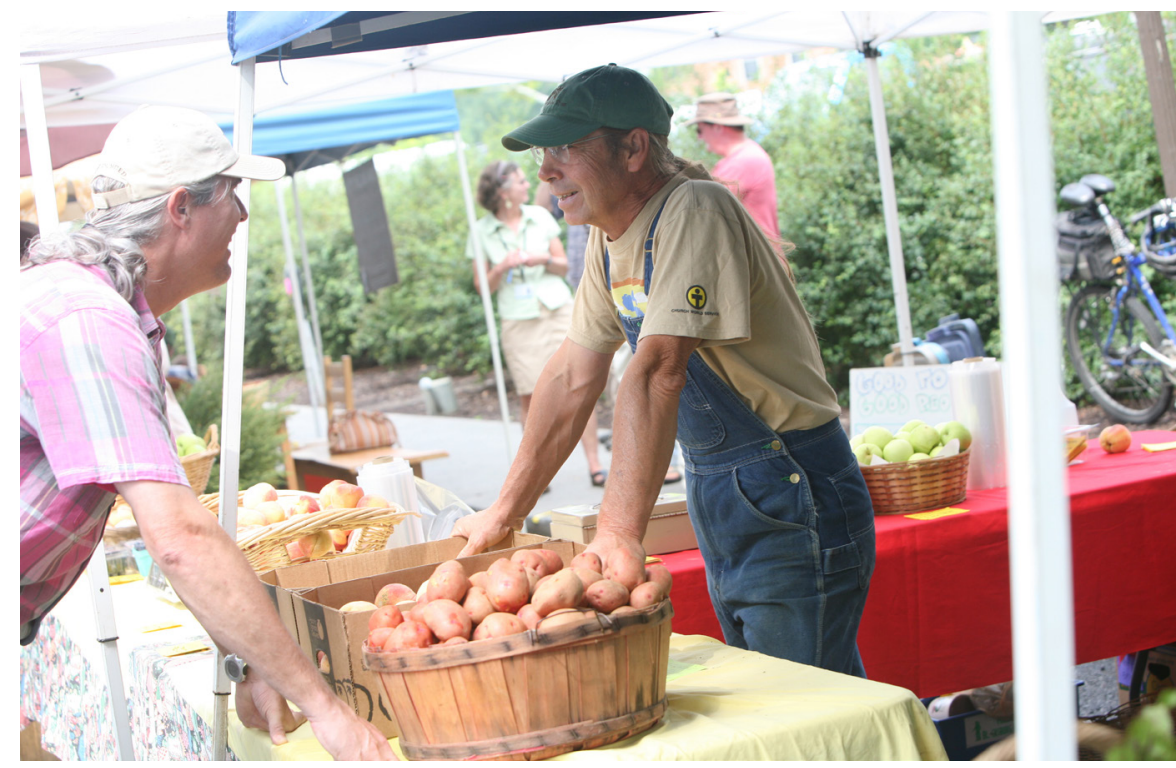

Image 0.16 Patron conversing with farmer Dennis Dove. 


\section{Introduction}

variety of produce and goods, particularly locally grown and handmade ones, as well as in its evolving assembly of stalls, tables, and displays.

We often think of farmers markets in contrast to supermarkets. These elements that make up farmers markets are powerful enough to sustain them in the face of the predominance of supermarkets, transcontinental trucking, and e-commerce. The predictability and standardization of the supermarket starkly contrasts with the excitement and uniqueness afforded by the space and place of farmers markets. Shopping in a supermarket offers monotony and detachment compared to the direct, idiosyncratic, and personal contact at farmers markets.

Ironically, the supermarket originally represented a sign of progress in post-WWII industrialization and the emerging corporate dominance of all commerce in America. In the realm of food production, bigger was (and is still often believed to be) better; chemicals promoted the growth of larger produce, and factories manufactured more goods with consistent quality. The use of preservatives was touted to extend "freshness." By the early twenty-first century, food purchased at the supermarket travels an average of $\mathrm{I}, 5 \mathrm{Oo}$ miles from its source. Over the past four decades agribusinesses have purchased over 6oo,ooo farms and aggregated them to form megafarms. ${ }^{4}$ Fortunately, in recent years many shoppers have discovered that locally grown food is fresher and actually tastes better; in most situations, small farms in close proximity -50 to 550 miles-to farmers markets are providing this delicious and more wholesome food.

In addition to the three types of markets I explore in this book, I have noticed in recent years the emergence of what is likely a fourth type of farmers market, the mobile market, which has the potential to increase access to nutritious food for hundreds of thousands of people in underserved communities. This food-on-wheels farmers market takes the goods to neighborhoods often referred to as "food deserts"areas often but not always urban, where it is difficult to buy affordable quality fresh food. In such places, neighborhood stores stocked with nutritional edibles have vanished; only convenience stores with cheap and unhealthy fast food persist. Small grocery stores in walking distance from one's home have been driven out of business by big box stores with food departments, such as Wal-Marts, which are strategically 
positioned on the edges of towns and cities, easily accessible by car rather than by foot.

Mobile markets do not necessarily follow the same rules of placemaking that I have identified with heritage buildings, open-air pavilions, and pop-up canopy markets. Nevertheless, they serve important functions that cannot be denied. I explore some of these mobile markets at the end of the book along with stories about nonprofit groups that team with municipalities to establish community gardens and urban farms to grow their own food. No matter how one looks at it, farmers markets of all types have led the local food movement and continue to alter how our food is grown and distributed across America. The continuing evolution of farmers markets reflects our changing way of life, how we produce and how we consume food. Healthy eating improves our bodies, and urban farms improve our landscape. 



\section{CHAPTER}

1

\section{FOOD WITH A FACE}

SPEND ABOUT Two hours most Saturdays throughout the year at my hometown market chatting with vendors, shoppers, the market manager, and sometimes out-of-town visitors (see image I.I). The conversations vary in topic and duration. Some exchanges highlight current events around town and on campus, such as those occurring during Sustainability Week each year, while others focus on food production on local farms, from mushroom hunting to making kimchi or strawberry jam. One day while chatting with former market director Ellen Stewart, I asked her why she thinks people want to shop at farmers markets (besides to buy food). Ellen said, "It is about sharing knowledge. When I think about all I have learned about food, farming, and the environment from these vendors here, it is amazing. With all the information on the internet, there is still a high value in hearing, and learning in person from the farmers doing it every day, season to season."

Ellen also talked about her interaction with students enrolled in Virginia Tech's Civic Agriculture and Food Systems Minor, which offers multiple opportunities for civic engagement. For instance, the Civic Ag Minor requires students to complete fieldwork in collaboration with 


\section{Chapter 1}

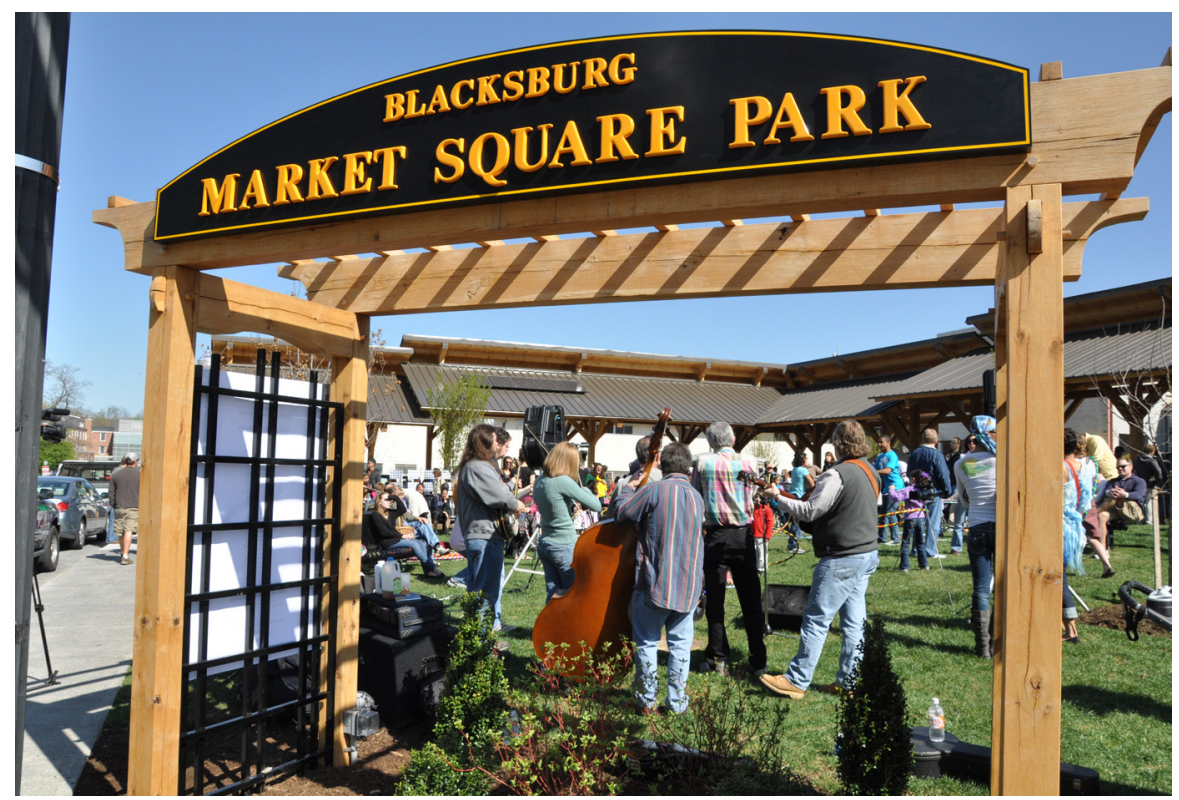

Image 1.1. Market day at Market Square Park.

community partners through development of meaningful and mutually beneficial service learning projects and experiences. Community partners include our farmers market, local farms, university dining services, and nonprofit-managed community gardens.

Standing alongside Ellen at the market, I could not help but notice how the architecture of the pavilions and park encourage relaxed and informal exchanges. For example, a vendor is conversing with a shopper who's leaning against a column, a guitarist and a drummer are sitting on a bench in the park playing music while onlookers sway to the melodic rhythms, and families nestle together at a table on the adjacent terrace enjoying food they'd purchased at the market. The configuration and modulation of the pavilion, the adjoining paved terrace, and the park with benches weaving among trees in the grass provide discrete places for individuals and families to gather in close proximity to each other and share in collective meaning-making. I read once on the Pomegranate Center's website, "Unintentional encounters happen in intentional places"2 (see image I.2).

In general, shoppers have more face-to-face verbal exchanges at a farmers market than at a supermarket. And they arrive at farmers markets as a family or with someone else, while most shoppers go to super- 


\section{Food with a Face}

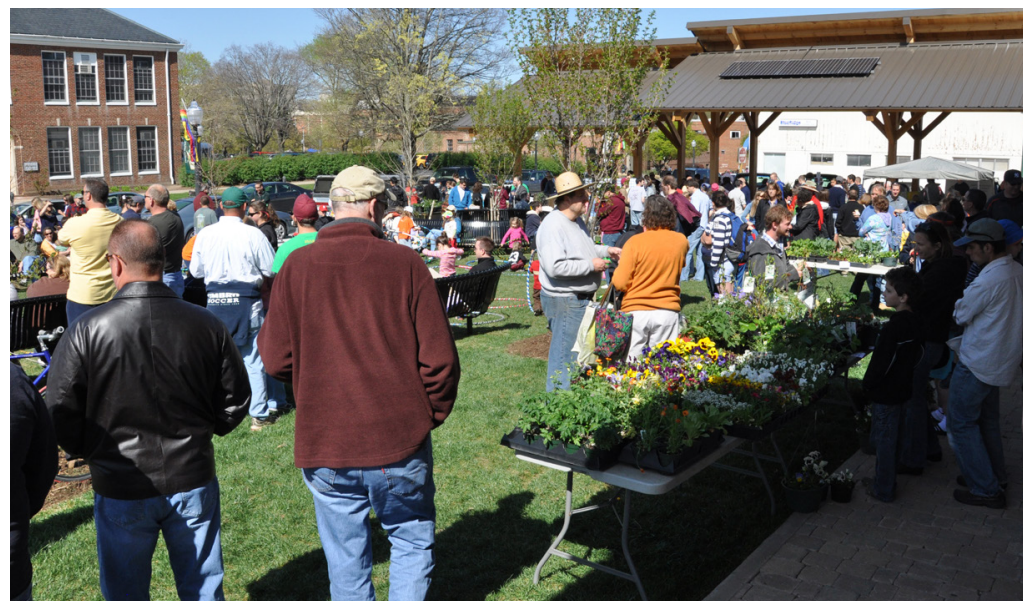

Image 1.2 Lots happening at the Blacksburg Farmers Market.

markets alone. ${ }^{3}$ The capacity of farmers markets to promote and sustain person-to-person interaction that builds a sense of community and the value of place stands out in this age when electronic social media dominates how we "talk" and "share." The importance of "food with a face-food that has a unique and important story behind its creation"4 is the topic of Brian Halweil's book Eat Here: Reclaiming Homegrown Pleasures in a Global Supermarket, in which he contrasts the anonymity of food bought in a supermarket or big box retailer to that purchased at farmers markets (see image I.3).

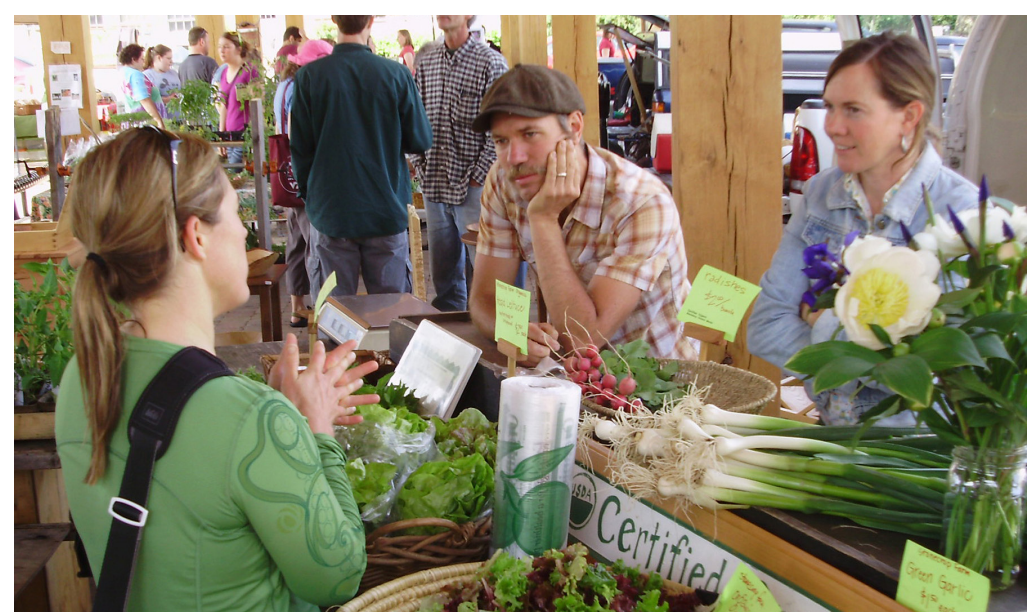

Image 1.3 Patron talks with farmers Bert Webster and Gwynn Hamilton. 


\section{Chapter 1}

In many communities there are not a lot of opportunities for people from different backgrounds to mix, to get to know each other and feel a sense of kinship. As I show in this chapter, farmers markets are one of the few places where this interaction does happen. This is fundamentally different than churches, which divide along sectarian lines, or theaters and performing arts centers, which feature entertainment that by definition requires audiences to remain silent during the show. Farmers markets foster engagement among people of all ages, mixed ethnicities, and varied economic status. The latter became apparent to me through disbursement of SNAP tokens at my market to individuals and families I know in various settings other than the market, but who had otherwise showed no indication of their need to receive federally subsidized food assistance.

The writer Lucy Lippard gets at the importance of events in creating a sense of place when she states, "Place is latitudinal and longitudinal within the map of a person's life. It is temporal and spatial, personal and political. A layered location replete with human histories and memories, place has width as well as depth. It is about connections, what surrounds it, what formed it, what happened there, what will happen there." 5 Historian J. B. Jackson adds the significance of recurring events over time to place-making in his essays about the American landscape. He writes, "The sense of place is reinforced by what might be called recurring events. A sense of place is something that we ourselves create in the course of time. It is the result of habit or custom." ${ }^{6}$ In this way farmers markets are manifestations of a sense of place created not simply in the moment of an experience, but also through repeated visits. Lippard's and Jackson's writings helped me better understand how collective meaning-making at farmers markets becomes attributed to its place. These influences range from cultural history to urban identity, and the conditions can vary from climatic to proximity to farmland.

Belmont, CA, market patron Joan Dentler summed it up in a Belmont Patch editorial in which she wrote, "Farmers markets serve an important social purpose as a community gathering place where neighbors can stroll, chat, eat and do it all over again next week; it is more than just a place to pick up fresh produce. It's become a hub of social activity and nonprofit outreach, providing residents with live music, as well as a place to pick up recipe ideas and tidbits on nutrition and 


\section{Food with a Face}

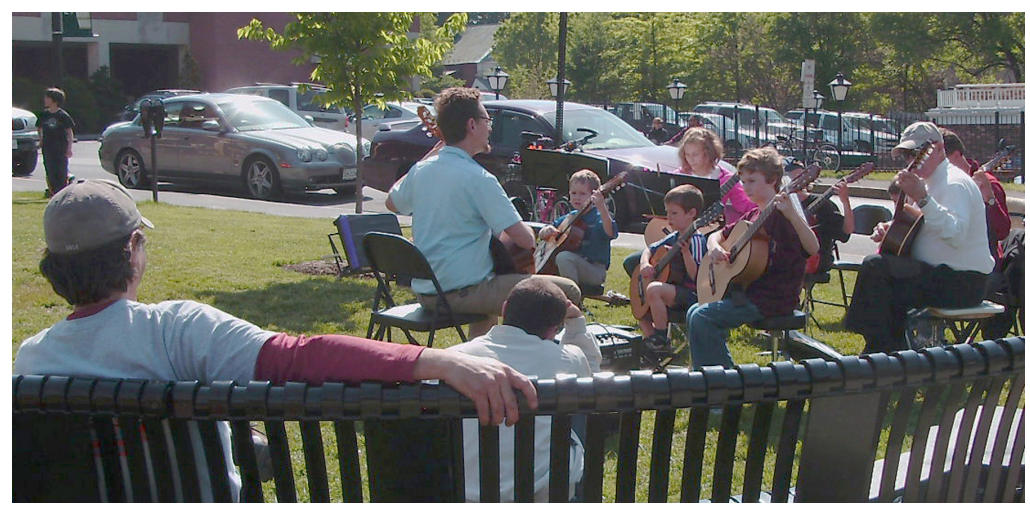

Image 1.4 Renaissance Music Academy musicians play at the farmers market.

sustainability."7 In this way, farmers markets, as part of a person's weekly or seasonal routine (whether vendor, shopper, or observer), fulfill part of the human need for individual and social meaning-making.

Planned or spontaneous, farmers markets' capacity to sponsor and sustain civic engagement provides opportunities for public celebration. Most of these markets host monthly events during market hours, and due to their identity within the community, serve as the location for other organizations to sponsor events affiliated with its hometown market. Regardless of the type of farmers market-permanent structure or temporary pop-up canopies-the ritual of visiting these markets gives meaning to its location for shoppers. Meaning-making is amplified on special event days when, for example, an adjoining street is closed and a large tent is set up for tastings of fresh food from market vendors. Events give new meaning to a market for some, while the market gives special meaning to the event for others (see image I.4). Longtime customers and newcomers alike sense the synergy between special events and regular market activities. The myriad of events reflect the seasons in the foods available as well as the politics du jour; some promote what the vendors sell, while others offer cultural enrichment.

Local and adjoining community residents enjoy tomato tastings in August, salsa festivals in September, and slices of apples in October, as well as annual chili cook-offs and ice cream socials. Musicians who play on market days attract teenagers, families, and retirees alike to hang out and listen. Some market events feature local artists from painter to poet, others partner with fundraising organi- 


\section{Chapter 1}

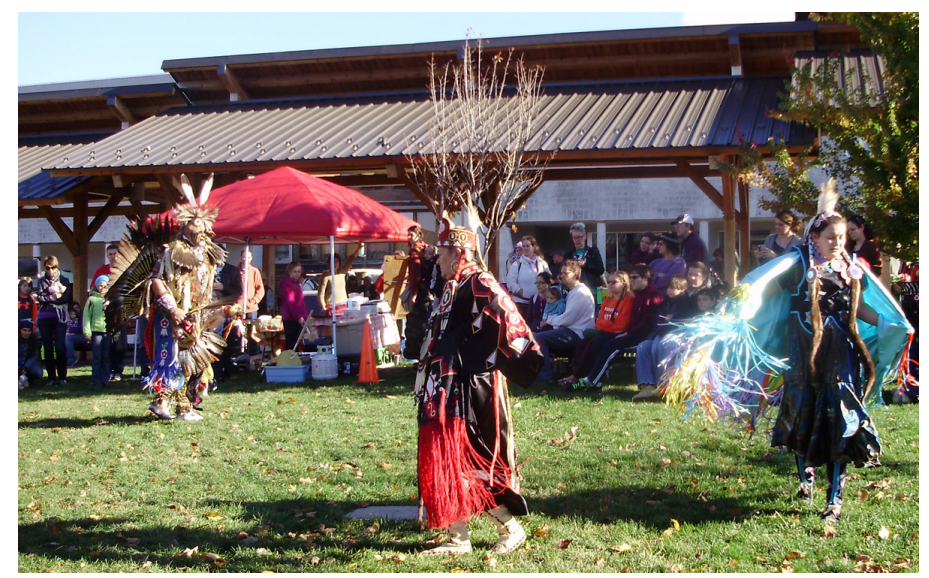

Image 1.5 Native Americans perform ritual dances at the Blacksburg Farmers Market.

zations that sponsor $5 \mathrm{k}$ fun runs and bicycle races that begin and end at the market. "In many cases, markets become a forum for politicians, community activists, and other community leaders to raise awareness about local issues," writes Halweil. ${ }^{8}$ Farmers markets are magnets for human expression and interaction (see image I.5).

Such is the situation at Blacksburg's annual Breakfast at the Market, a significant community event since 2005. It occurs in mid-July and attracts more than three hundred people for a couple of hours starting at 8:30 a.m. Twenty-five plates of frittata, cubed potatoes, peach halves topped with blueberries, and slices of whole grain breads are served every fifteen minutes. Former mayor Ron Rordam and his wife, Mary, have attended the 9:30 seating most years since the event's debut. Each year, the then-mayor and other local leaders use the market event as an opportunity to interact with the citizens as they stop to chat with people sitting at the tables set up under a thirty-foot by forty-foot tent straddling Draper Road adjacent to Market Square Park and overlooking the hubbub of market shoppers. Bill Brown, the former Blacksburg Police Chief, has regularly attended the event for years, and used it as a forum to reach his constituency during his run for Montgomery County Supervisor. After winning reelection, Town Council member Susan Anderson moved among the diners thanking her constituents as they finished their meal. All of these local public figures maintain that the annual breakfast is an event that they simply cannot miss; the event and the market unite the community as members share in the pleasure of 


\section{Food with a Face}

local food-further evidence that farmers markets are scenes of convivial civic interaction.

I first became aware of civic engagement by observing my mother's father, Grandpa John, helping others through Kiwanis Club activities and Grace Lutheran Church initiatives. My understanding of commitment to one's community expanded upon reading the fifteenth-century treatise On the Art of Building in which Leon Battista Alberti details what an architect must know and what architecture must provide. According to Alberti, one concept the architect must consider is civitas-the inhabitants of a city and the union of its citizens. He gives status to civitas by stating that it is essential for creating a civil society, both in its meaning as "civic," involving government, and "public," involving local populace. Furthermore, in locating a city that will serve this entity, the architect must also consider the significance of place. Alberti asserts:

the pleasures of life are sweeter when available at home than when they must be sought from elsewhere. And so, the foremost authors of antiquity, who recorded other people's views and their own ideas on the subject, considered the ideal location for a city to be one that provided for all its requirements from its own territory and would not need to import anything. ${ }^{9}$

With my broadened grasp of an architect's civic responsibilities, I find farmers markets fulfill an important role as a part of every locale's civil society-in their capacity to provide local food, and as a community gathering place (see image i.6).

Christian Norberg-Schultz offers a succinct definition of place in his seminal book, Genius Loci; he writes, "place is space that has a

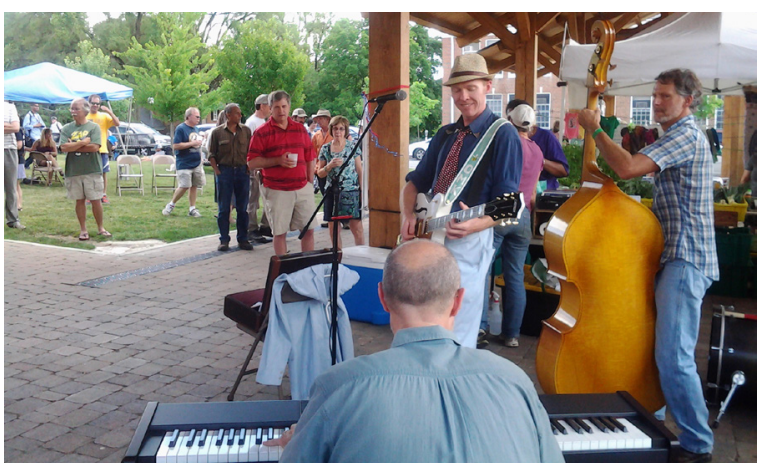

Image 1.6 Local musicians entertain at Mingle at the Market in Blacksburg, Virginia. 


\section{Chapter 1}

distinct character." of temporary pop-up canopies, farmers markets stand out among their surrounding buildings and landscapes, as there is a high ratio of people to goods for sale and occupied space. This level of activity and scale of interaction and interface that is characteristic of these types of markets distinguishes them from other food shopping experiences, such as conventional supermarkets and big-box retailers. In these kinds of stores, the sense of place is one of vastness lacking in memories to cherish; spaces where the aisles are wide and long, the ceilings are unnecessarily tall and cluttered with dangling fluorescent lights and there are lots of products but few workers. Shoppers scurry the aisles ending up at an array of check-out stations staffed with uniformly dressed cashiers who input into the register the number of a food item they often do not know the name of.

People arrive at farmers markets in various ways; those who live in neighborhoods more than a half-mile away reach the market via bus, rail, or car. Walking towards the market they join others, who reside in adjacent houses or apartments, toting empty canvas bags ready to be filled with fresh goods. Strollers and wagons serve double duty as carriers of children and bags of market goods. Sidewalks and street crossings are jammed with more pedestrians than on surrounding blocks. From a hundred feet away or less, the market's allure heightens as its excitement and activity becomes visible.

Upon arrival at the market, the frequent modulation and uniqueness of the individual stalls of pop-up tents and pavilion markets emphasizes the human scale. Shoppers progress through the market in distinct ways; many moving in and out of stalls while others amble along and gaze into or pause around a compelling display. The personality of the vendor is manifest in the display of goods and signage. Most vendors have a unique and notable sign, often with graphics hand-painted onto wooden boards or canvas. There are no shopping carts to fill and take to the cashier to buy; each selection and purchase involves a transaction-a physical and verbal exchange-with the grower or maker of the food.

Separately and together the features of farmers markets translate into places of transformational consequence. These markets' capacity for collective meaning-making establishes them as institutions that provide continuity and stability. In Making Common Sense, authors Wilfred 


\section{Food with a Face}

Drath and Charles Palus stress that humans have an innate need to make sense of experiences by mentally linking them to specific places and/or certain activities. Communities make meaning by engaging in a repeated activity over a span of time. Often a group of initial strangers coalesce through shared interests and experiences, and thus form a sense of community. The community spirit and mutual assistance inspired by farmers markets has a noteworthy impact, as sociologist Robert Sommer observes: "In a complex bureaucratized society nobody seems responsible for anything. The solution is tangible action on a local level by the people immediately concerned with a problem." "Throughout my explorations, I've found many examples of situations in which citizens come together to establish new markets, build new structures, and renovate existing ones not only in pursuit of fresh locally grown and made food but also for the stability it offers as a place of community. In general, the regularity of the physical presence of farmers markets provides an innate sense of continuity. The permanence of heritage building and open-air pavilion markets, however, offers the most stability.

My involvement with the Blacksburg Farmers Market over the past two decades and the sense of community I've cultivated with my hometown market, its vendors and customers, motivated me to use my architectural background and experience to increase the presence and permanence of the market through construction of a pavilion and pocket park that would share its identity with the farmers market. To begin the process, I met with vendors to determine their needs and wants; I proceeded to develop alternative proposals, all of which included a small park as community gathering place. The pavilion project led me to numerous discussions with town council and staff members, downtown merchants, and residents. As Blacksburg citizens learned about the project, they supported it through financial donations-they understood what the structure and park could offer to the farmers market and downtown area. The L-shaped pavilion that shelters the twice-weekly farmers market and the adjoining park serves as a community gathering place for everyone every day. The position of the park on the corner of the block gives it high visibility and easy access. The curvilinear benches facing towards the center of the park and the trees along the perimeter provide sense of enclosure (see image I.7). The continuity of the cobblestones under the pavilion, in the parking area, 


\section{Chapter 1}

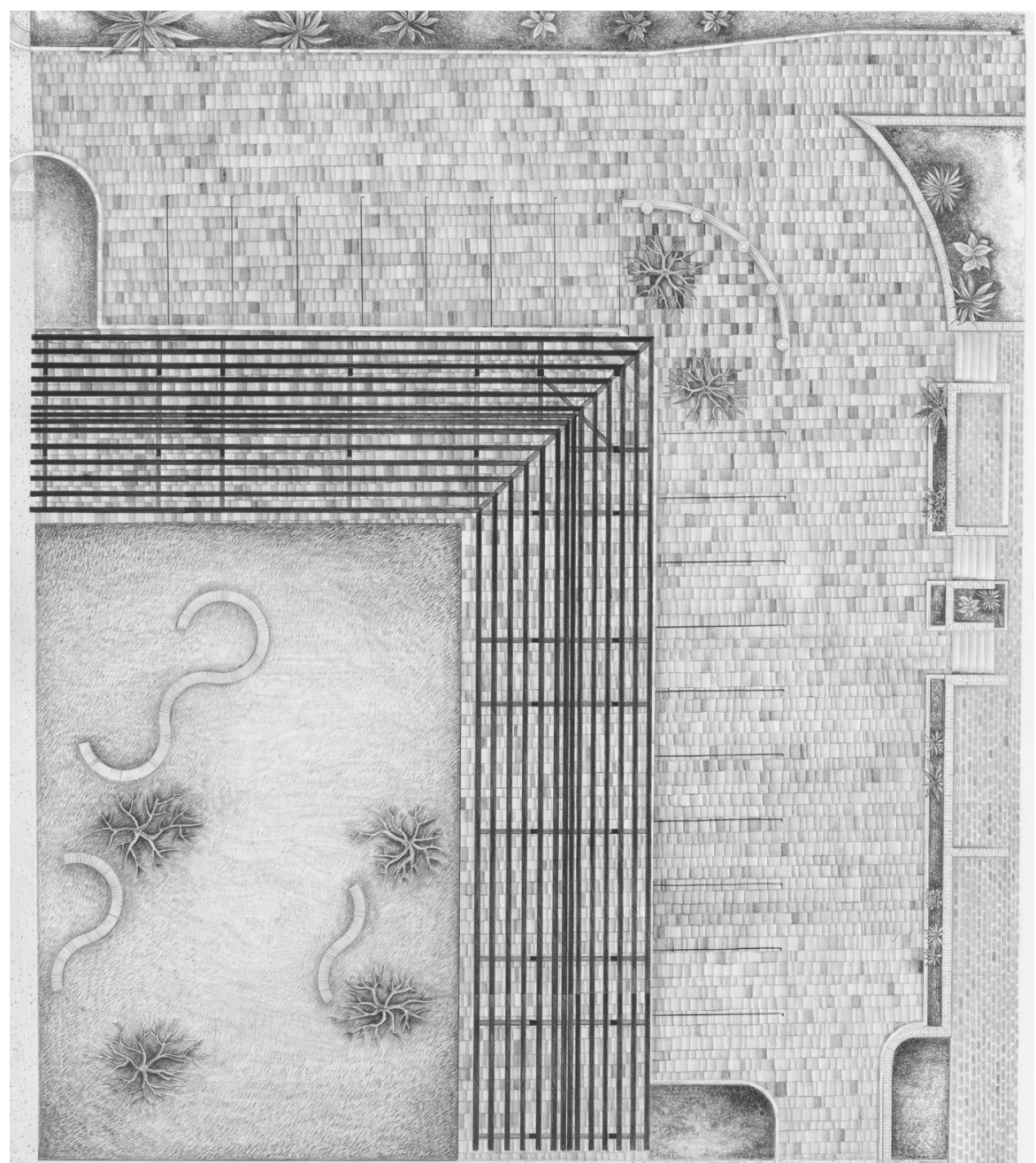

Image 1.7 Site plan of the Blacksburg Farmers Market.

and in the alley impart a sense of a public plaza. In just the few years since the completion of the structure and park in 2009, Market Square Park has become a downtown destination-a place with material substance, shape, texture, and color-that promotes community gathering and collective meaning-making (see image r.8). On non-market days during the spring, summer, and fall, over thirty local musicians gather for Market Square Jam starting at 8 p.m. on Wednesdays, and Vintage Market occurs on the second Sunday each month from ro a.m. until 5 p.m. Blacksburg's Market Square Park pavilion is a vivid example, representative of many I have found in my exploration of market pavilions, 


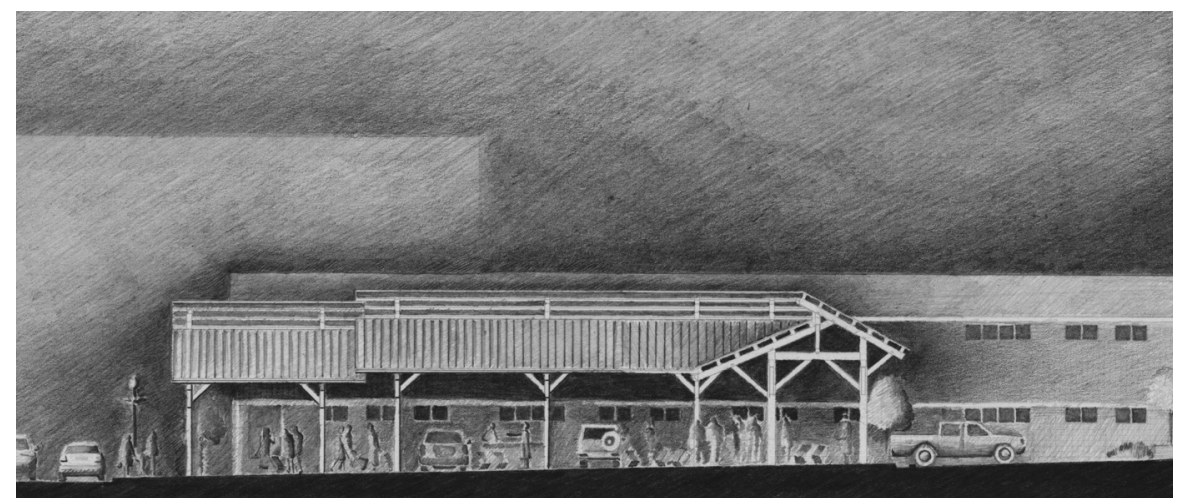

Image 1.8 Cross section of the Blacksburg Farmers Market.

illustrating the capacity of a farmers market to establish sustainable connections among citizens and fulfill the enduring human need for civic and social engagement.

Writer and local food advocate Michael Pollan asserted on National Public Radio in 2009, "Farmers' markets are the new public square in America." I2 In Mark Francis's and Lucas Griffith's book about recently created public squares, they expand upon their significance. They write that such entities "signal a return to civic life and an opportunity to reinvigorate public space with social and cultural vitality." ${ }^{13}$ Indeed, the establishment of markets as new public squares is more of a renaissance than a new phenomenon. Farmers markets in America find their origins in the nineteenth-century municipal public markets that were located in conspicuous, convenient places within the main public square or thoroughfare of its cities. Town plans in that era depicted the location of public markets in the center of town amid commercial and governmental districts, with ease of access from densely populated adjacent neighborhoods. James Hamilton's plan for Lancaster, Pennsylvania designated one of the four squares at its main crossroads for the Central Market, which opened in $\mathbf{1 7 9 5}$, and remains a vital part of its downtown and surrounding community today. It was also common practice to situate a market house in the middle of a major thoroughfare, like the High Street Market in Philadelphia. In the early eighteen hundreds, American leaders anticipated the eventual need for market houses and designated specific locations for them in town plans, such as in Detroit's I807 plan, Indianapolis's I82 I plan, and Louisville's I 836 plan. ${ }^{14}$ Unfortunately, few of these buildings remain today. Fortunately, 


\section{Chapter 1}

the Library of Congress has numerous historic photos, which are the focus of public market historian Helen Tangeris's book Public Markets-a visual sourcebook of the buildings and spaces designated as urban marketplaces for fresh food.

Tangeris has written extensively on the design of nineteenth-century market houses and their placement within urban settlements, with the aim to nurture civic culture through access to fresh food for America's mixed ethnicities with varied incomes. The strong tie between location of farmers markets and civic culture is apparent even for temporary markets that set up pop-up canopies in public plazas and streets once a week. "For the most part, people shop at the farmers market that's convenient to their home or work-in fact, that's the point," notes Washington Post writer Nancy McKeon. ${ }^{15}$

As mentioned in the Introduction, farmers markets are also often set up in open-air pavilions located in a park or adjacent to a parking lot. Whatever the configuration of these structures, they invite performances and events other than farmers markets, ranging from holiday celebrations and family reunions to church picnics and fundraisers. In Virginia, Salem's farmers market is set up in an L-shaped open shed adjacent to a downtown parking lot Mondays through Saturdays from April to December. However, for the annual town-sponsored Star Bar-B-Q event in late September, the farmers market closes early to enable a change of vendors: the Bar-B-Q vendors offer their grilled pork specialties to the delight of locals. Towns and cities increasingly rely on the value of these mixed-use venues to assist in reviving and maintaining thriving downtowns. Likewise, since the early ig8os, politicians in American cities have found that farmers markets provide an effective strategy for economic redevelopment that brings new vitality to public spaces and creates a vital focal point for existing neighborhoods. Charleston, West Virginia's Capitol Market sets up under sheds constructed in the late rg9os adjoining its rehabilitated train depot adjacent to downtown, which contain year-round food vendors and a coffee shop. Pop-up canopies that comprise San Francisco's Ferry Market cover the plaza next to its restored Ferry Terminal Building, which houses a butcher, a baker, a cheese-maker, and other regionally sourced food. Buildings that were once vital to a city as transportation access now provide entrée to healthy locally grown and prepared food, while also serving as places for community gathering. 
I find that each of these seemingly separate constituents is actually part of a wide-reaching regional community. As Brian Halweil concludes, "Local food might also provide one of the few remaining connections to nature, rural ways, rural people, and an awareness of what is happening to our food supply." ${ }^{16}$ Mark Francis and Lucas Griffith elaborate on the influence of farmers markets on people's awareness of food, saying, "Within the United States, the current farmers market movement marks a return to an historical means of food distribution, and a rediscovery of the value of locally or regionally produced foods." ${ }^{\prime 7}$ One inspiring illustration of the community that farmers markets create is their ability to forge relationships between restaurant chefs and a nearby farmers market, and thus with farmers. In cities across America, there are legions of chefs who have sought out the freshest, tastiest food available through farmers markets. These chefs have in turn invested in ensuring that the food they use was grown or produced directly from a local farmer. They have commissioned farmers to grow specialty crops and heirloom varieties of foods that have dwindled in the past half century.

I discovered a vivid example of this symbiosis while researching Chicago's Green City Market in Lincoln Park, where chefs come to discover the ingredients they will need for the menu they aspire to serve at their restaurant. Their weekly interactions about specific crops or meats and methods of production naturally evolved into alliances. This farmer-to-chef rapport was one of the aims that Abbey Mandel had for Green City Market when she founded it in 1997. (see image I.9). To this end, an email from someone at Green City is sent out once a week to more than 150 chefs describing what will be at market that week. Today over II5 of Chicago's restaurant chefs source food from farmers who sell at Green City. For instance, Three Sisters Garden grows specific varieties of squash for Prairie Grass Café as well as black beans and corn for Frontera Grill and Topolobampo. After the email notification, Brent and Beth Eccles of Green Acres Farm get special orders from chefs at Piccolo Sogno and the Sofitel Hotel. The marketplace serves as a location for delivery and pick-up for most chefs, but many chefs also shop on market day because some produce is only sold at the market. The Eccles say certain produce, like burgundy okra, is too hot an item to be on that email list. I find their comment reassuring: the role of the farmers market in providing access to fresh local food to the public at 


\section{Chapter 1}

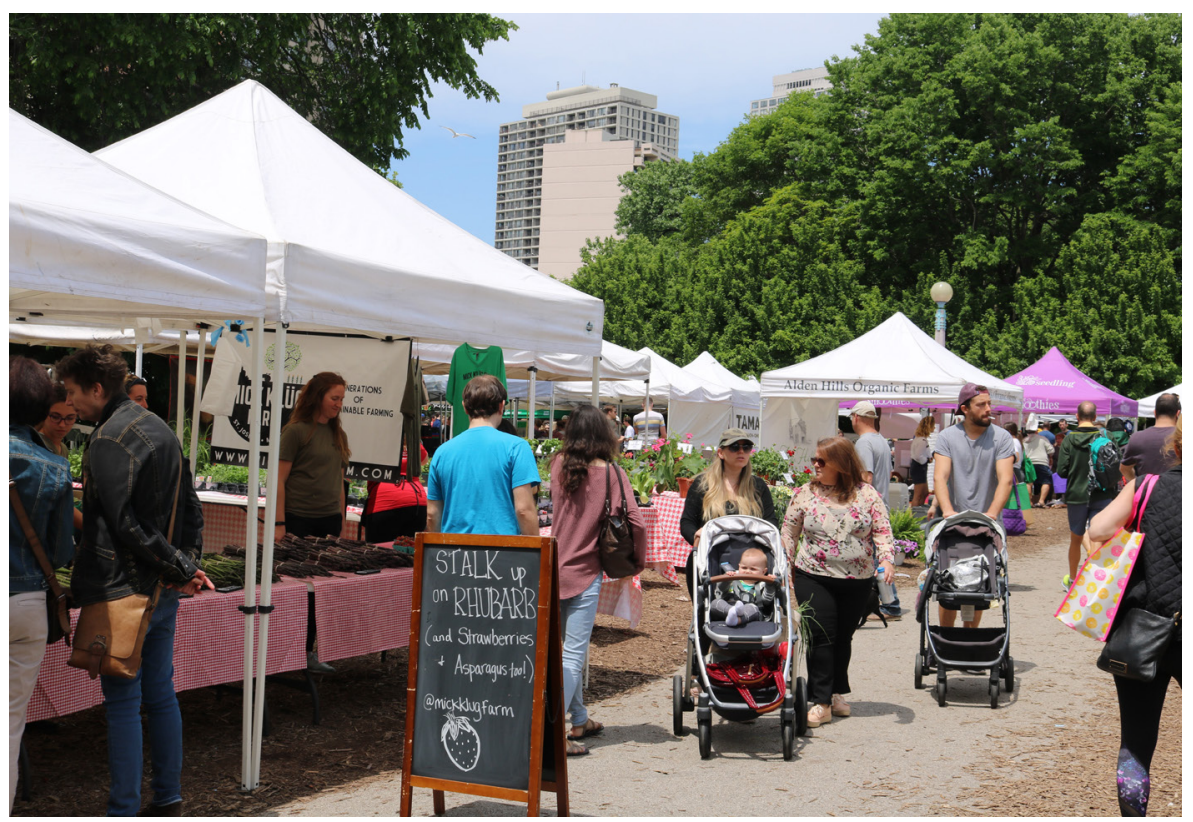

Image 1.9 Green City Market.

large remains a top priority, while the market also meets the desires of the elite chefs and their clientele. This is yet another illustration of the broad-based community that farmers markets nurture.

In this fashion farmers markets create a sense of camaraderie between chefs and farmers because chefs know they are cooking with the best ingredients-locally grown, and produced by farmers practicing nonchemical methods of production. In fact, some farmers view building a diverse supportive community as fundamental to their business-indeed, as part of their way of life and living. Such is the case for other vendors at Green City Market, Bare Knuckle Farm's Jess Piskor and Abra Berens, who host monthly farm dinners that include customers from the market. In this way people gain knowledge of how to prepare unfamiliar foods, while Abra develops a network of people who enjoy her cooking. Building community is also a part of the business plan for Glade Road Growing, a local farm that sells at my hometown market. After a conversation with Pat Bixler of Baseline Solar, Jason Pall and Sally Walker started transforming a portion of Bixler's property in 20I0. This would become their farm as well as home to other enterprises-Rising Silo Brewery and Tabula Rasa Restaurant. They also assisted the startup of Strong Earth Pork and Hoof-Hearted Farm. 
I am gratified to learn that there is an economic benefit to building community; it nurtures new small local businesses.

As mentioned in the introduction, another inspiring but very different way farmers markets connect with a broader community is through acceptance of monies provided to limited-income households by the federal Supplemental Nutrition Assistance Program (SNAP). But there is even more advantage for this segment of the population; many farmers markets not only accept this method of payment via electronic transfer but also have SNAP-based incentive programs that double the value of redeemed subsidies between $\$$ Io to $\$ 30$ each market day. Yet a barrier of awareness remains for a large portion of the eligible population: knowing that farmers markets accept SNAP and even will double the value often relies on individual farmers markets handing out flyers at local health departments and government assistance agencies. The nonprofit Wholesome Wave has banded together the independent farmers markets not only to expand their access to the USDA's Double Value Program but also to increase the available funding. One reason for Wholesome Wave's success is consistent data collection of program impacts, which in turn assists in developing outcomes that meet their goals. They survey farmers' market customers, vendors, and managers. They track federal benefit and nutrition incentive sales. In 2012, Wholesome Wave's statistics helped leverage their funding to raise an estimated additional $\$ 4$ million from public and private sources. In 2018 they report helping to support over I, 400 farmers markets in 49 states $^{18}$

In addition to these increasingly impactful outcomes, there is a by-product: this access also builds a sense of community for an often-disenfranchised population. Adelante Mujeres launched the Forest Grove Farmers Market in 2005, to foster cross-cultural exchange at a weekly community event that provides an outlet for small farmers and food producers to connect with the community by making healthy foods accessible through the SNAP Double Value program. ${ }^{19}$

I have also observed over the course of several years that, once the Double Value program was established at my hometown market, local churches and allied groups as well as individuals have made annual donations to increase the monies consistently available for our SNAP Double Value customers. For half a dozen years, local artists donated to our annual Art Auction, which benefitted our SNAP Double Value and 


\section{Chapter 1}

was held in conjunction with the local Agriculture Coalition's monthly free meal. Each year, around \$I,Ooo was raised through a silent auction that occurred during dinner. This amount of money translates to providing roo SNAP customers \$1o for \$1o of SNAP redeemed per market day. During those years, if a SNAP recipient shopped at our market every month from April through December, they could have received $\$ 720$ in additional funds to spend on fresh healthy food.

The acceptance of SNAP benefits at established farmers markets is also transforming marginalized neighborhoods through the emergence of a new type of market-the Mobile Market. Food deserts, as they are called, occur in situations where SNAP is not only a prevalent method of purchasing food (albeit usually processed and prepared fast food) but also where there are usually no grocery stores and very limited availability of fresh affordable food. From Washington, DC, to Chicago and across the country to the San Francisco Bay Area, residents in inner-city neighborhoods have benefitted from mobile markets since their emergence in 20Ir. Pioneering examples of this market type are discussed in Chapter 5. The symbiosis between rural and urban, country and city, and the farm and these markets is a growing necessity for every region's economic and cultural flourishing.

In the following three chapters I examine the physical and spatial characteristics of three established types of farmers markets: heritage buildings, open-air pavilions, and pop-up canopies, and the scales of interaction and interface that make them places for community gathering and civic engagement in conjunction with their function as purveyors of fresh, healthy, and local food. The conviviality of the vendors and patrons at each of these types of markets made a positive impression on me during my initial visits as a shopper-I've since made lasting professional and personal memories from subsequent visits as an architect studying farmers markets. 


\section{CHAPTER}

\section{2}

\section{HERITAGE BUILDING MARKETS}

7 astern Market began as a public market in the nineteenth century and remains a beloved Capitol Hill landmark in Washington, DC (see image 2.I). The building initially gained this status for the beauty of its design-intricately detailed brick walls with Romanesque arched portals invite shoppers inside a cathedral-like space with sunlight streaming through its circular clerestory windows onto an abundance of displays of produce, vases of fresh-cut flowers, trays of handmade sausages, and stacks of just-baked breads (see image 2.2). I had the pleasure of shopping there regularly for the four years that I lived on $7_{\text {th }}$ Street in a three-story brick Federal-style townhouse built in 1872 .

One of my neighbors told me that this densely populated district had sustained Eastern Market for over a century; locals have shopped there since i8 83 . Today, on Saturdays from early summer to late fall, over five thousand people shop at Eastern Market, many of whom live in or near the neighborhood. Most of the buildings that comprise Capitol Hill are distinctive in their cohesive residential style and modulation that define the streets (see image 2.3). Three-story brick townhouses, eighteen feet wide, dominate the intermittent two-story clapboard, 


\section{Chapter 2}

somewhat wider, houses. The solidly built brick residences with front stoops and wrought-iron fenced front yards were constructed during the Victorian era, I837-rgor. Other buildings of similar type and materials contain shops, stores, restaurants, and bars on the ground level with residences on the second and third levels. One can also see more recent schools, and civic and religious buildings as well as small public parks.

Eastern Market is an example of what I call a heritage building market, for its cultural value and its contribution to the architectural legacy of civic buildings. Historians refer to this type of building as a market house (in contrast to a less distinguished building type of the times-a shed or what we term a pavilion today), and most were

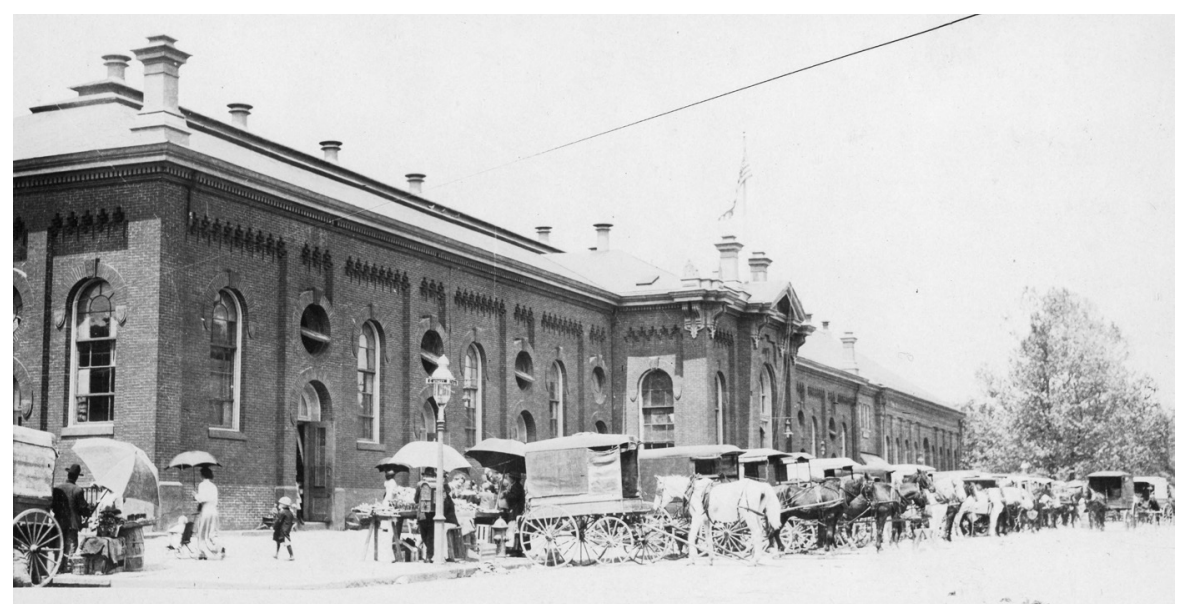

Image 2.1 View from 7th Street circa 1914.

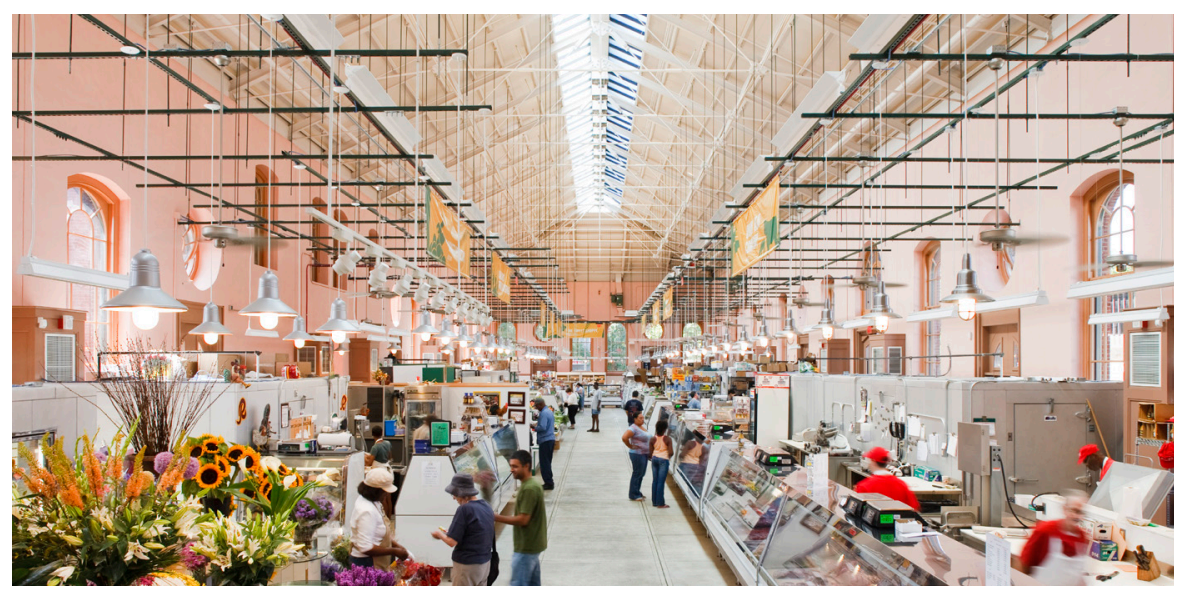

Image 2.2 Interior of Eastern Market after renovation 2009. 


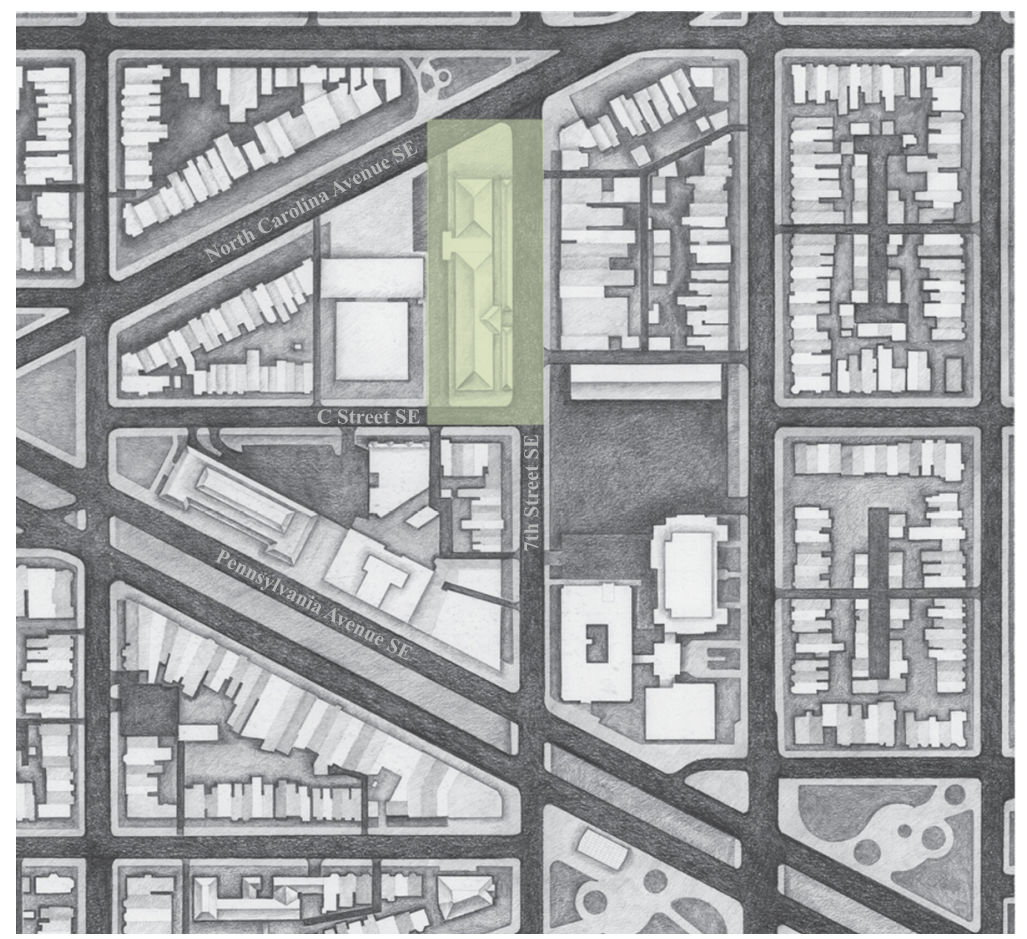

Image 2.3 Figure ground plan of blocks surrounding Capitol Hill's Eastern Market.

built in the nineteenth century during an era of progressive regulations and new construction of municipally inspired and regulated food markets in the United States. Public markets were places where people of varying societal status could find fresh, healthy food at affordable prices while simultaneously enabling farmers to sell their harvest or handmade food merchandise. The term "heritage" refers to the fact that vendors at this type of public food market often come from families that have been part of the market for generations. For instance, at Lancaster, PA's Central Market vendors have included their seniority-status stalls in their wills for more than two centuries so that their beneficiaries can continue to sell at this treasured public market.

The decision to build a market house demanded careful deliberation on the part of local government because the resulting building would be a city landmark meant to exemplify civic pride and validate a community's view of itself. The decision-making process was complex in that it required government leaders to consider a range of factors: site, financing, public support, simplicity and flexibility in design, and 


\section{Chapter 2}

a location convenient to buyers and sellers. To proceed with construction, it was necessary to gain the approval of the leaders and citizens of the neighborhood and governing district. The importance of steady and lasting community commitment and consensus cannot be overestimated, as it is ultimately what saved from demolition both of the markets featured in this chapter. Without collective allegiance stemming from each market's prominence and value as cultural icon, neither would have survived.

Market houses in America followed the European public market model, particularly in regards to their situation within a municipality as an essential part of the public infrastructure and civic culture. They were centrally located within a downtown or surrounding neighborhood with easy access to primary roads and waterways. These buildings existed as a hub for the town's social interactions and commercial transactions. The daily necessity of obtaining fresh food was inseparable from the collective activities of urban living. Parades began or ended at the market; politicians held debates there. The significance of a market's location ensured a renowned place for public ritual and ceremony.

Two public and farmers markets that remain open and thriving today serve as case studies for this chapter: Washington, DC's Eastern Market and Cincinnati, OH's Findlay Market. Both of these markets were built in the I8oos and remain situated within neighborhoods comprised of well-built residences crafted by hard-working, highly skilled immigrant populations of the times. These seminal examples illustrate that Eastern and Findlay Markets provide the neighborhoods of Capitol Hill and Over-the-Rhine, respectively, with a place of community gathering and civic interaction, as evidenced by numerous and diverse annual cultural celebrations and food-themed festivities throughout the year. In these ways these buildings imbue tradition and sense of belonging to a place and its society.

Generally speaking, heritage building markets exhibit several of the architectural and urban design features outlined in the book's introduction. Through their function as gathering places, heritage building markets become landmarks-a point of distinction and reference within a neighborhood and urban fabric. The market building physically dominates a city block, often covering most of it. The building's entrance façade provides a backdrop for various events and activities on the 


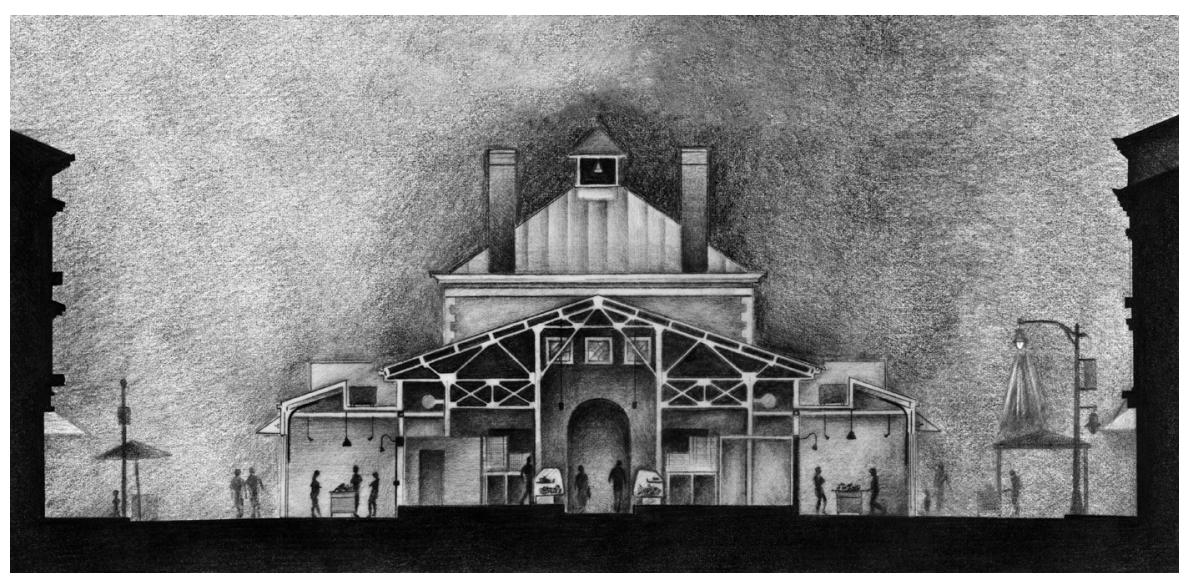

Image 2.4 Cross section of Findlay Market.

adjacent public plaza and in the surrounding streets. Markets of this type, particularly the two featured in this chapter, have a reciprocal rapport with stores and businesses across the adjacent streets. Likewise, nearby commerce develops a symbiotic relationship with this type of farmers market, as patrons of the market also make purchases at the proximate companies as part of their shopping routine throughout the week (see image 2.4). Another distinguishing attribute of heritage building markets is that they are open year-round for multiple days of the week, which increases the likelihood of them becoming a part of one's shopping habit. The permanence of individual stalls allows vendors to embellish their displays with props such as tools of the trade, more elaborate signage than temporary set-ups, and special lighting. Despite these common scales of engagement, however, each individual heritage building market differs in other particular ways that make each one exceptional. They defy categorization beyond scales of interaction and interface.

\section{Eastern Market: Washington, DC}

On my first visit to Eastern Market in August 2005 I walked through the entrance-set into the building's eighteen-inch-thick brick exterior wall-and was immediately struck by the astonishing array of colors and aromas that greeted me. The ambiance of the interior of the market building exuded tradition and ritual. I paused to think about the countless activities that had occurred within the market's walls over 


\section{Chapter 2}

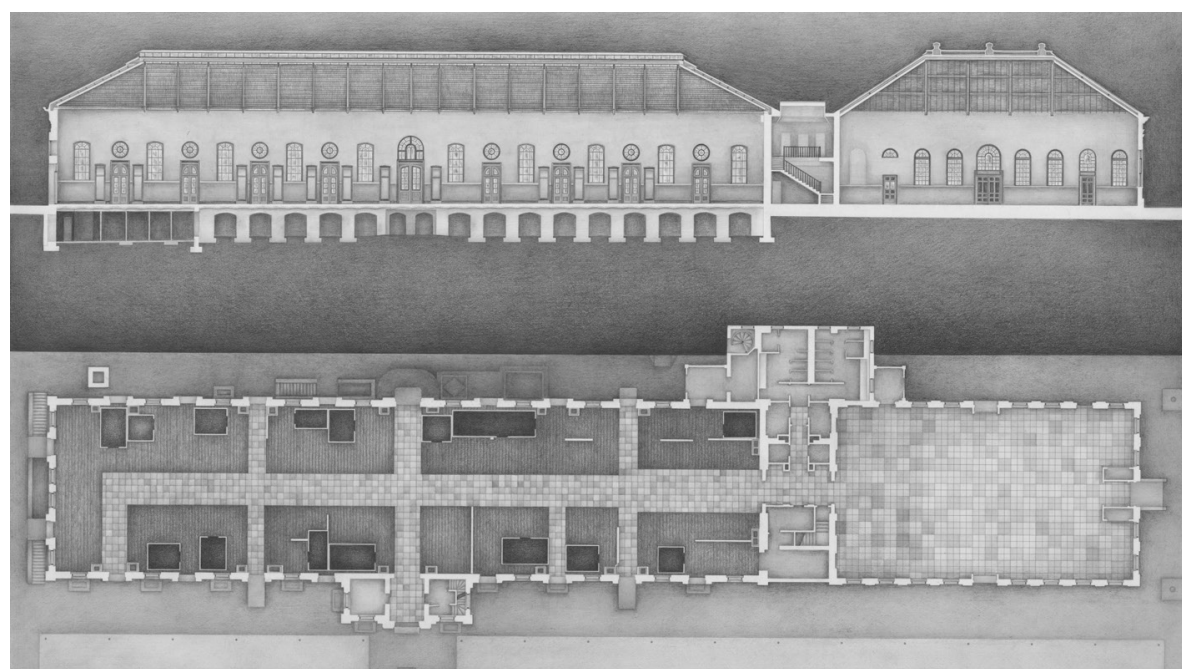

Image 2.5 Plan and cross section of Eastern Market.

generations and how its architecture had influenced those interactions. I tried to imagine how many people had benefited from the market over the years given its easily accessible location, within walking distance of the Capitol of the United States and associated office buildings as well as the surrounding neighborhood. Access was expanded in 1977 with the opening of a DC Metro light rail stop sharing its name: "Eastern Market."

Since that first visit I have returned many times to pick up whatever vegetable is in season, fresh-cut flowers, or a wedge of handmade cheese. Each time I step across the threshold below its thick brick arched portals, I feel a sense of joy. Even on overcast dreary days, the building's numerous large windows allow daylight to stream into its cavernous interior, which measures about 50 feet across and 200 feet long (see image 2.5). The interior space is unobstructed by columns or walls; lightweight iron trusses carry the span from load-bearing brick walls that define its perimeter. A baker's dozen of stalls along its perimeter face a central aisle; vendors define their stall boundaries with display cases, shelving, tables, and signage.

The colorful display of Thomas Calomiris \& Sons Fruit and Vegetables is situated in a prominent central location (see image 2.6). One Tuesday morning in 2006, Maria Calomiris greeted me with a smile and a soft "hello." At the time, Maria was the wife of Chris Calomiris, 


\section{Heritage Building Markets}

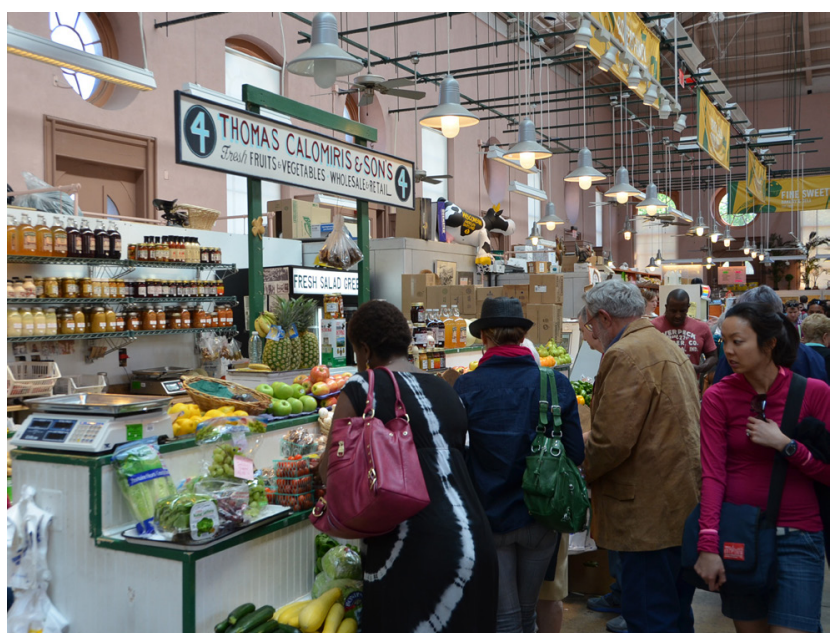

Image 2.6 Renowned Calomiris stall.

who died in 20II, having been a seller at Eastern Market with his father Thomas all the way back to $1963 \cdot{ }^{2}$ As Maria greeted me, she stood behind a three-tiered stack of neatly arranged fruits and vegetableslemons, grapes, apples, onions, broccoli, cauliflower, carrots, rhubarb, and asparagus-with Greek honey, olive oil, and baklava tucked in here and there. I grabbed a bunch of bright green asparagus stalks along with a lemon. Mrs. Calomiris slid them into a paper bag along with a banana-the Calomirises have a longstanding tradition of gifting customers an extra piece of fruit, most often into the hands of children. Her late husband was known to slip an apple or pear into the jacket hoods of youngsters walking through the market on their way to school. Washington Post journalist Bart Barnes sums up the Calomirises' generosity and stature, saying, "If there were such a position as 'dean of vendors and merchants' at Eastern Market on Capitol Hill, if there were such a job title as 'face of the market', if the market had a 'keeper of memories', they could all have been filled by Chris Calomiris."3 Barnes's statement exemplifies the sense of community that shoppers feel when purchasing from the Calomirises' stall. Their stall design enables intimacy with customers amid the enormity of the interior. I found that this is not at all unusual; it is rather a necessary attribute of the most successful vendor stall setups in all types of markets experienced during my explorations.

On another visit to Eastern Market in 2006, the voice of Ray Bowers caught my attention as I crossed the threshold of the entrance near 


\section{Chapter 2}

C Street. "How are you today?" he asked. I replied, "Enjoyed that Stilton you sold me last week." As he gestured towards a refrigerated eight-foot-long glass-covered case full of cheeses, Ray grinned and said, "What may I get for you this time?" At Ray's stall, the display apparatus is elevated and all but disappears from view as shoppers gaze eye-level at cheeses. The distinct forms of cheese-loaves, wheels, and wedges-draw attention to the subtle hues of creamy white streaked with ash veins to bold golden orange with flecks of pepper. During this visit the classic five-year-old New York State Sharp Cheddar sat alongside regionally sourced Artisan Farmstead Cheeses from Meadow Creek Dairy in Galax, Virginia, and Cherry Glen Goat Cheese Company in Boyds, Maryland. I tasted "Appalachian," a buttery, slightly sweet cheese that melted on my tongue-all the convincing I needed to decide on what to purchase that day. Since ig64, Ray's stall and company, Bowers Fancy Dairy Products, have provided shoppers with a wide variety of cheeses to suit the pleasures of the most discerning cheese lovers (or tyrophiles, as they are known).

Across the wide aisle, glass-covered cases delineate the boundary of Canales Deli, a double-width stall offering specialty sausage, homemade barbeque, rotisserie chickens, deli meats, and salads. The immaculately clean, shining cases stand five feet high. Small, colorful signs reveal names of products-such as Jamon Iberico, Parma Prosciutto, and New Orleans Andouille-from places all over the world, including Spain, Italy, and Germany. One case displays colorful trays of different kinds of fresh coleslaw, mixed vegetable concoctions, and fruit salads. The Canales Deli stand may look similar to deli sections in some high-end supermarkets but Jose Canales can tell you the story of the quality of the ingredients and how each product is made; he has offered high-quality deli products at Eastern Market since r983. Canales's presence and interaction are a testament to the instinctive value that shoppers place on face-to-face communication as a means of maintaining direct ties to their food and its preparation. Shoppers patiently wait in a short line while he completes each transaction with a smile and a greeting of "Enjoy!"

At the northernmost of end of the building, very tall vases filled with brilliant bluish-purple irises stand atop a wrought-iron garden table (see image 2.7). These elegant flowers are the namesake of this stall, Blue 


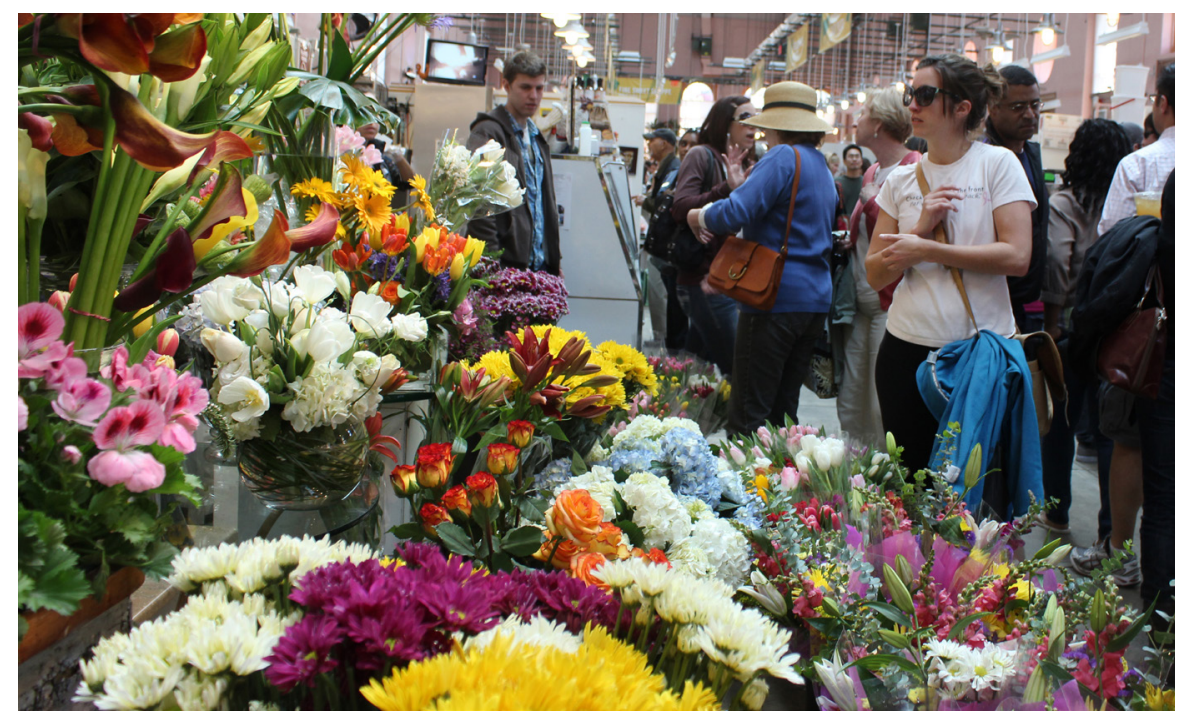

Image 2.7 Blue Iris Flowers stall.

Iris Flowers. It is composed of a dazzling rainbow of colors and array of scents (particularly the perfumes of lily of the valley and hyacinth), which differentiate this stall from the food vendors. Among the flowers stands a small handwritten sign that reads "flowers by Angie"-the name of the woman who stands among the tables covered with containers and vases of all sizes brimming with bouquets as well as individual stems of flowers. This arrangement is another example of space planning that invites intimacy between buyer and product, which allows a lasting relationship to develop between the producer and the purchaser.

Just a few feet away, people gather along and in front of a counter to enjoy a savory meal at Market Lunch. This short-order grill is a DC eatery renowned for its blueberry buckwheat pancakes served at breakfast as well as its lunchtime burgers, fresh fish sandwiches, softshell crabs, and oysters. Customers standing in line observe the cooks in action beyond the counter, which is assuring in a way that modern food courts in shopping malls are not. On many days, I have observed various kinds of people enjoying their meal together: DC police officers in uniform, local businesspeople in professional attire, moms in jeans with kids in strollers, and tourists sitting side-by-side relishing a meal at Market Lunch. The closely situated small tables with chairs and counter with stools provide an eat-in kitchen cozy atmosphere that fosters a 


\section{Chapter 2}

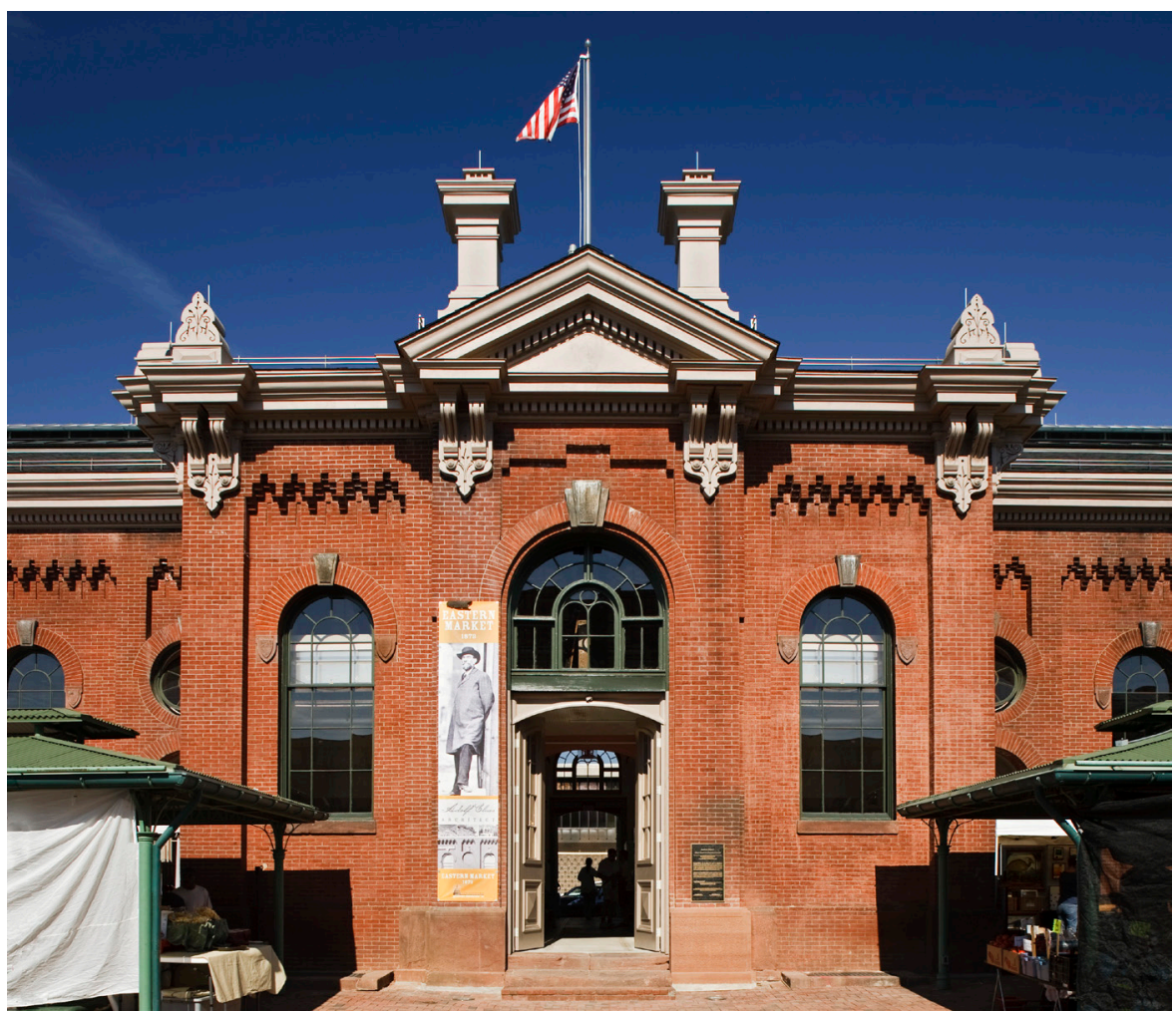

Image 2.8 Eastern Market entrance showing brick detailing and large windows.

sense of familiarity among strangers-just another way in which public and farmers markets nurture a sense of community.

As I left the market building one day, I noticed a plaque on the wall that read, "Adolph Cluss, Architect." The text commemorated the building's bicentennial and honored Cluss-specifically, the beneficial contribution that his innovative architecture and urban design plan made to the city. At the time of its construction, Eastern Market was an influential example of Adolph Cluss's trademark red brick building style that replaced the grandiose classical granite and marble public buildings of early nineteenth-century DC. Although Eastern Market was constructed of common red brick, its proportions and abundant windows give it elegance akin to a cathedral (see image 2.8). Innovative building features included high ceilings with natural ventilation and lighting and an open floor plan with convenient access for people and goods. The building had a hammered-glass iron-framed ventilating skylight extending along the entire ridge of its roof, which has been 


\section{Heritage Building Markets}

covered up since the I970s, but was redesigned and rebuilt during the building's renovation in 2009. ${ }^{4}$

Cluss (1825-1905) designed over seventy buildings in DC, including four buildings on the National Mall (though of these, only the Smithsonian Arts and Industries Building remains). He repeatedly chose to design buildings that appealed to the human scale and nurtured a sense of community. As city engineer, Cluss developed a plan that narrowed DC's unusually wide streets by permitting property owners to plant and maintain gardens in the unpaved strip of street right-of-way in front of their houses. He proposed regulations allowing the construction of row houses with bay windows, porticos, and balconies extending beyond the front property lines, which eliminated the bland, flat facades of early nineteenth-century row houses. ${ }^{5}$ Cluss's vision and successful implementation remains physically apparent in DC today, particularly along the streets on Capitol Hill encompassing Eastern Market.

One feature of Eastern Market, vital to its continued success but not designed by Cluss, is the minimal Victorian-era-inspired lightweight metal structure covering the sidewalk along the South Hall on $7_{\text {th }}$ Street. On Saturdays from April through October the shelter protects vendors from rain and sunshine. Although only comprised of about a dozen vendors, this group significantly expands the amount and variety of fruit and vegetables, as well as generating a festival atmosphere that attracts other types of shoppers. Upon the arrival of these vendors, the adjoining block of 7 th Street is closed during market hours as more vendors set up pop-up canopies on the other side of the street in front of two- and three-story brick buildings occupied by neighborhood-oriented businesses offering diverse goods and services on the ground floor, and professional offices and residences above. Similar to the street frontage of the neighborhood's residences, display windows extend out onto the brick-paved sidewalk, and recessed entrances with bay windows overhead undulate the street frontage of the row houselike buildings.

At the corner of $7_{\text {th }}$ and North Carolina, residents and tourists alike fill more than two dozen tables situated on the brick-paved public plaza. One day as I stood waiting for the traffic signal to change, I overheard two women discussing how they liked to prepare the vegetables they regularly bought at Eastern Market. One commented to the 


\section{Chapter 2}

other about how fortunate they are to have the market so close to their home. The other responded by elaborating on how the market positively impacts the greater community through regular events and education about eating healthy food. This unsolicited validation of Eastern Market's positive impact on the community intrigued me; I wanted to find out more about neighborhood leaders and residents that had kept this local (and national) treasure from demolition, a fate that many other public markets have confronted, and sadly, a fate that many heritage building markets have succumbed to.

For decades since the r95os Capitol Hill residents had fought against gentrification and new development that would alter the continuity of the neighborhood's historic architecture. One of the earliest efforts of residents to protect the integrity of its neighborhood was stopping the extension of the Southeast Freeway into the historic district. Since then many buildings have been saved and renovated through the leadership of the Capitol Hill Restoration Society.

Nonetheless, Eastern Market was in dilapidated condition and this had many Capitol Hill residents concerned for its survival. When I gleaned the community meeting records, I learned Eastern Market's South Hall had a deficient heat system and no mechanical air conditioning. Consequently, during the summer months people rarely shopped at the market after two o'clock in the afternoon. Washington, DC, is well known for its hot and humid summer days and, on multiple occasions, shoppers had passed out due to extremely hot temperatures inside the building. For many years those managing the market and overseeing maintenance of the building struggled with other poor environmental conditions that barely met public health standards: brief but recurring rodent infestations and sewage back-ups in the basement, to name a few. At the time (1992), Eastern Market operated under the Eastern Market Act, part of the DC governing code, which stipulated that a private management company would service the building; the company "managed daily operations, which entailed establishing and collecting rents as well as maintenance such as snow removal, trash service and janitorial duties." ${ }^{6}$ In r999, the local government sought to make changes in Eastern Market's management and maintenance. Legislative changes placed the Department of Real Estate Services (DRES) as the oversight agency 
and formed a new group, the Eastern Market Community Advisory Committee (EMCAC), to advise the DRES on Eastern Market's operation, management, and capital improvements. The EMCAC would represent the entire Eastern Market community-stakeholders including community organizers, elected DC officials, vendors and professionals that ran proximate businesses on Capitol Hill. Despite these encouraging advancements towards preserving the building, it remained dilapidated and unchanged until 2003, when word got out that some DC government bureaucrats "thought to tear it down, or at least gut it and build a whole new interior similar to what happened to the Georgetown Market around $1985 . " 7$

The possible degradation of Eastern Market triggered an outcry from residents and supporters alike who valued its physical structure and character as well as seeing its importance to the community. They knew what had happened in Georgetown, when its historically important market was gutted, leaving only the outer shell of the building. The interior was subdivided into upper and lower levels via a mezzanine. Dean \& DeLuca, a privately owned gourmet grocery store, inhabits the space today. It serves only people willing to buy high-priced food. Eastern Market advocates did not want the same thing to happen to their market building.

The third remaining historical market in DC, O Street Market, has also struggled to escape demolition-a 2003 blizzard caused its roof to collapse, leaving only its façade still standing. Built in I88I, O Street Market is situated in the northwest Shaw neighborhood. After a decade of delays, construction began in 2012 for significant adaptive reuse of the site that includes a chain supermarket (Giant), and upscale apartments. ${ }^{8}$ Despite the building's repurposing, only its historical architectural facade remained intact and it no longer serves as a public market. This outcome ignited concern for the survival of Eastern Market and strengthened community activists' resolve for authentic preservation of the building.

Many people viewed the repurposing of O Street Market (like that of Georgetown) as economically successful, which placed pressure on government officials to treat Eastern Market in the same manner. However, Capitol Hill residents and the market vendors had a different vision: a restoration of the South Hall that maintained its function as 


\section{Chapter 2}

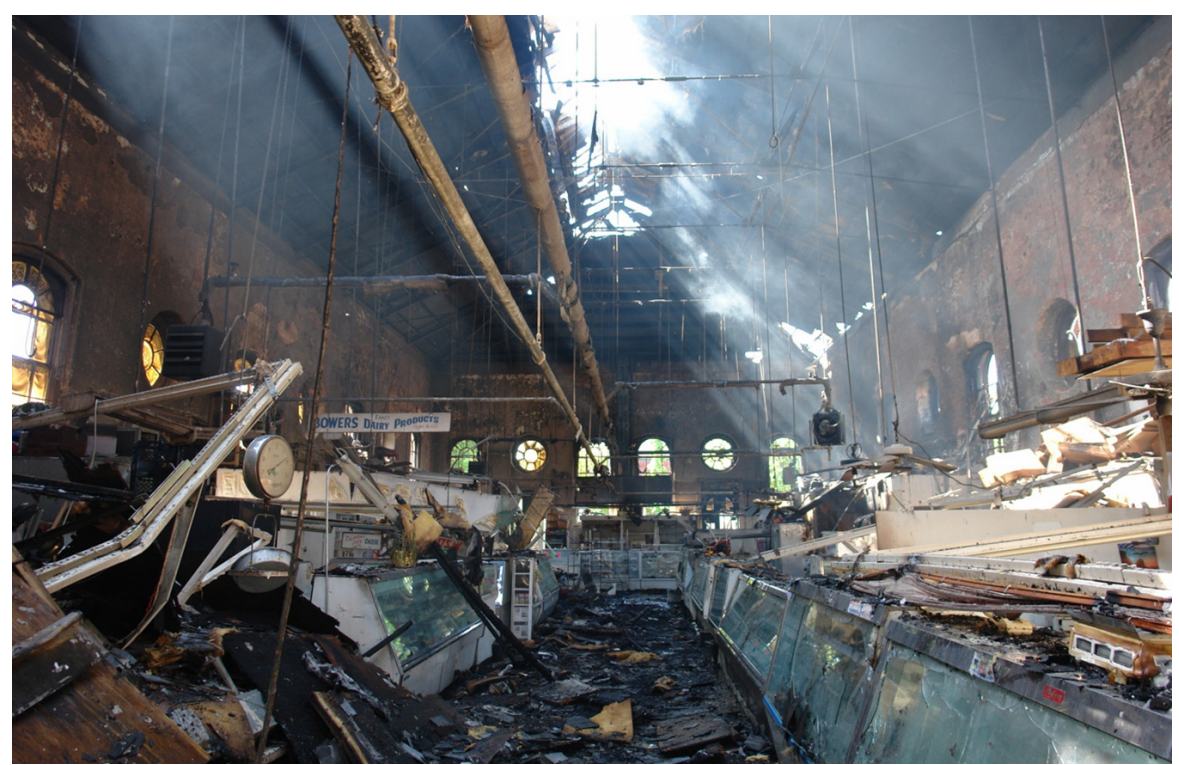

Image 2.9 Interior post fire 2007.

a public market, its architectural wholeness inside and out, and kept the community uses of the North Hall. Local architect Baird Smith at Quinn Evans Architects was one of the forces behind the proposed work. Smith recalls, "Over a two-year period (2003-2004) EMCAC, the vendors, and neighborhood residents came together to come up with recommendations of how the market could be rehabilitated," while still complying with today's safety and accessibility standards for public spaces. ${ }^{9}$ This combined community effort kept Eastern Market from demolition; in fact, the government (which now owned the land and building) instead planned for an extensive three- to five-million dollar renovation. ${ }^{\text {Io }}$ The community saved Eastern Market from the fate of Georgetown's market, and even better, catalyzed the government to complete a historically sound renovation that would ensure the building survived intact for another century or more.

Fast forward to 2007; the chirps of spring songbirds filled the air one early April morning when interrupted by fire trucks blaring their sirens and screeching down 7 th Street toward Eastern Market. I leaned out of my bedroom window and saw flames flickering and smoke billowing from the roof of Eastern Market two blocks away. After sunrise I walked down the street towards the market; the voices of neighbors talking in disbelief had replaced the noise of the sirens. Small groups of 


\section{Heritage Building Markets}

people stood at the corner of the building staring and pointing at the charred remains, their hands covering their mouths in disbelief. Others stopped on their walk to work and gawked open-mouthed. The threealarm fire (out of five levels of response-a five-alarm fire being the worst) had severely damaged the building; the fire had nearly obliterated the roof, twisted the steel trusses, and blew out the glass windows, but the thick exterior brick walls stood intact (see image 2.9). Kimberly Konkel, a regular at the market, summed up the sense of loss, saying, "This is devastating. I'm surprised how emotional it feels to lose a building." "I

After the fire Mayor Fenty declared Eastern Market "a historical landmark that has been the lifeblood of the Capitol Hill neighborhood and a great source of pride for the entire city for more than a century." ${ }^{12}$ He pledged to rebuild the market and immediately worked to find the necessary funds. Remarkably, the "struggling to get funded" renovation with estimated costs of three to five million dollars quickly grew to a twenty-million-dollar reconstruction and preservation project. The sense of community and determination of those involved would prove essential as city officials grappled with a much larger restoration and

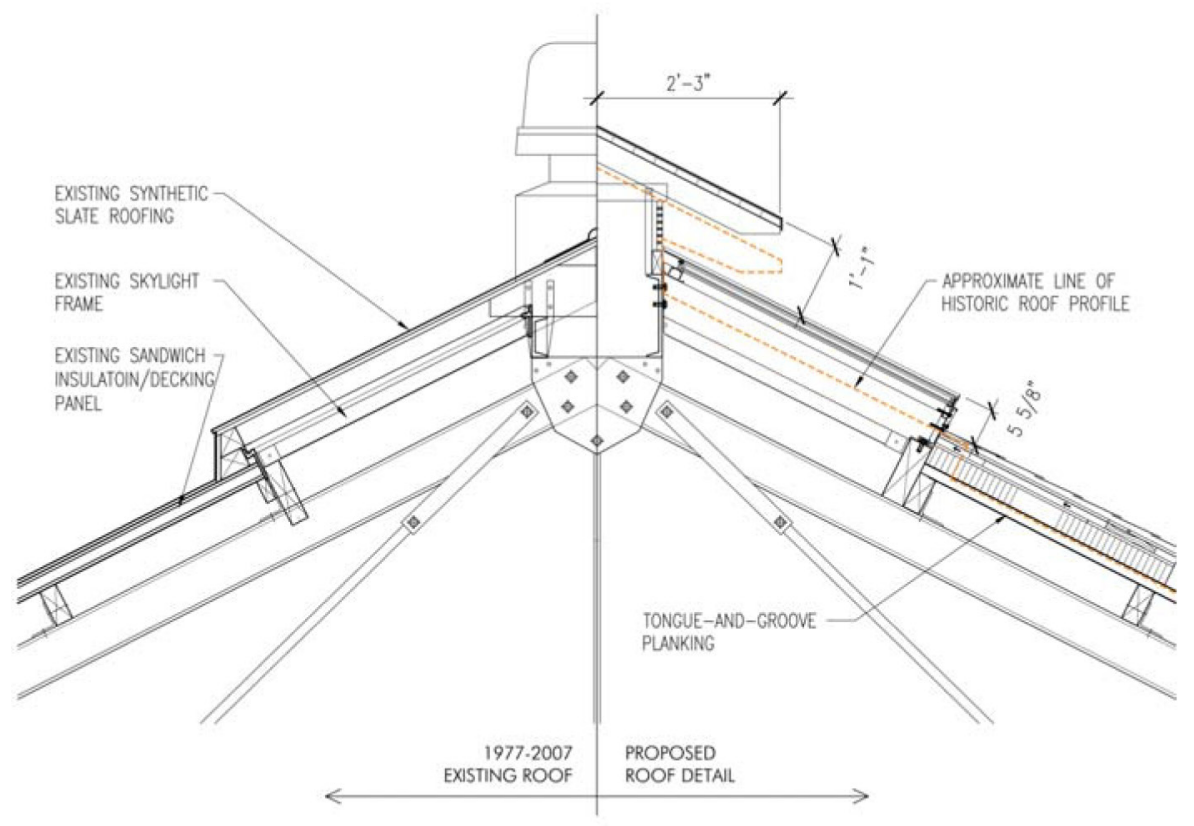

Image 2.10 Sectional drawing of roof 1977-2007 (left) and new roof with ventilating skylight (right). 
Chapter 2

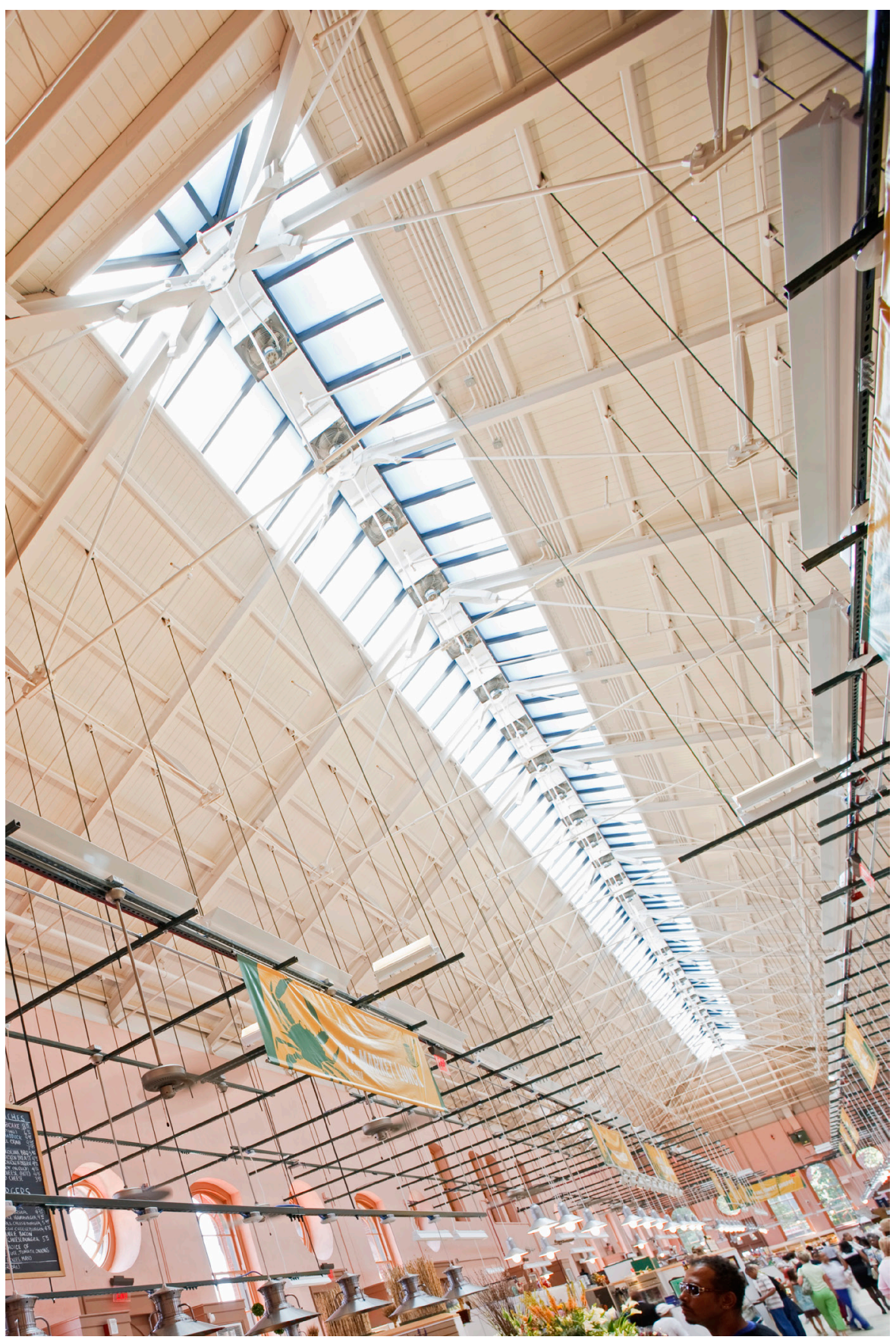

Image 2.11 Looking up at the new ventilating skylight. 
the additional complication of needing to immediately build a temporary structure to keep the thirteen indoor market vendors in business (and equally important, keep patrons satisfied). Fortunately, Quinn Evans Architects had drawings of the existing building, knowledge of Cluss's architecture, and a professional reputation of "preserving and maintaining the historic and character-defining elements of buildings while providing for their contemporary use."13 The reconstruction necessitated replacing the iron trusses, such that the roof was completely rebuilt, which included a new ventilating skylight similar to the original design (see image 2.Io and image 2.II). Restoration included masonry repair and window replacements, as well as installation of long overdue improvements including mechanical air conditioning, and automatic fire suppression systems.

Eastern Market reopened in June 2009, just over two years after the devastation. Having moved away soon after the fire, I returned for a visit in November 20II. On that visit and on others since, the sidewalk on the north side of the market building bustles with shoppers carrying bags overflowing with lettuces, herbs, and other produce. As I walked through the central brick arch portal once again, I felt a familiar sense of joy that this time turned into unfettered delight as I scrutinized the renovation. Quinn Evans Architects had rebuilt the 200-foot-long skylight true to its authentic design-the skylight flooded the market stalls with sunlight. They deftly minimally modified the rest of the building to meet modern health and safety codes while still maintaining the building's architectural integrity. My first visit to the "new" Eastern Market felt like meeting up with a dear old friend. I am not alone in my admiration of its high-quality design and food. Since its completion in 2009 Eastern Market has garnered numerous awards. ${ }^{14}$

\section{Findlay Market: Cincinnati, Ohio}

Of the nine public markets that operated in Cincinnati from the mid-nineteenth century to the mid-twentieth century, only Findlay Market remains. The other eight still standing in the early half of the twentieth century fell prey to interstate highway construction in the rg6os that cut through the city to accommodate the increasing use of automobiles, and urban renewal programs that demolished underutilized buildings as many people moved from distressed cities to the newly constructed 


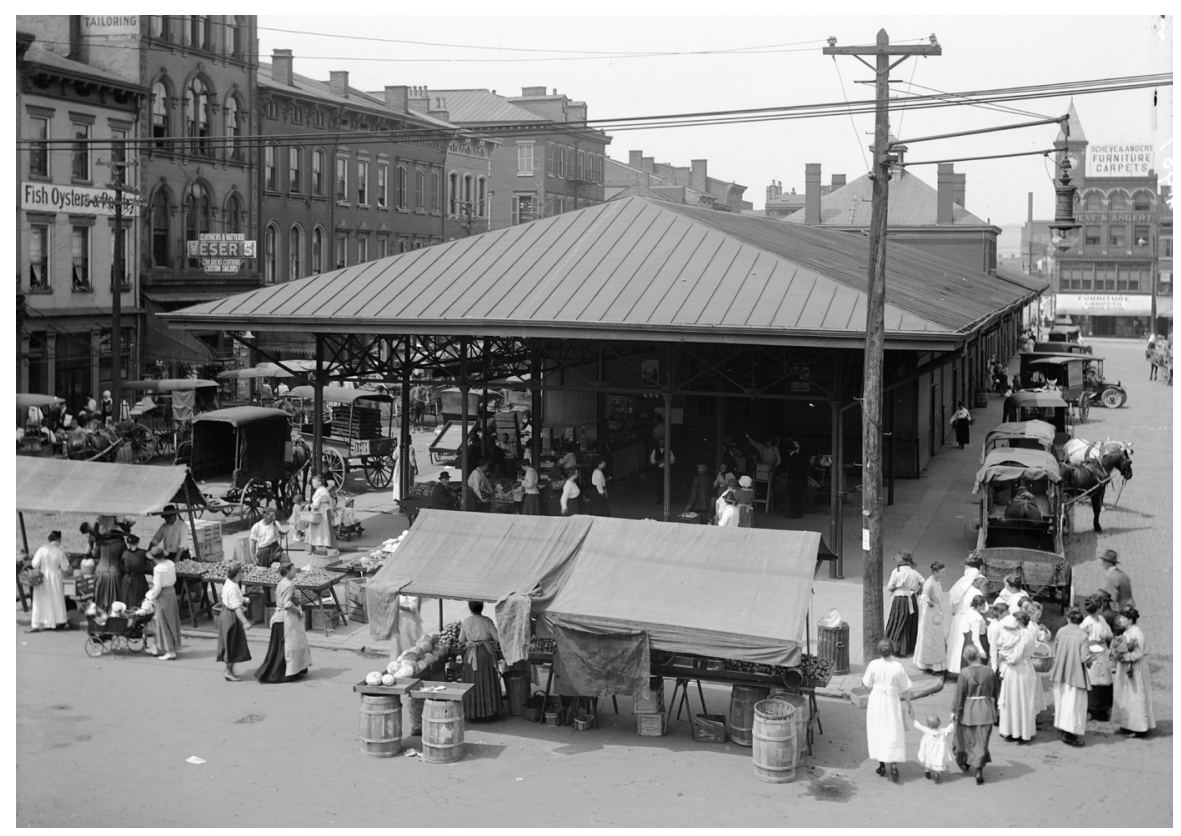

Image 2.12 View of Findlay Market from Race Street circa 1930.

idyllic suburbs. Like Eastern Market, Findlay Market's survival is due in large part to the community's activism and desire to protect and preserve its historical landmarks. Built originally as an open pavilion under the direction of city civil engineer Alfred West Gilbert (I8I6-Igoo), the cornerstone of the market was laid in October I852, but disputes with contractors regarding shoddy workmanship kept the market from opening until $\mathrm{I} 855^{\mathrm{I5}}$ (see image 2.12). While impressive in length at nearly 400 feet, the industrial scale and plainness of the original building make it all the more amazing that it survived destruction.

I first visited Findlay Market in late May 2004 with my friend Lia Braaten, who lived in Cincinnati's Over-the-Rhine neighborhood where the market is located. From three blocks away, we began encountering crowds that noticeably slowed our pace as we walked along Race Street. Turning onto Elder Street, the extremely long structure with a bell tower in the middle came into view. Baskets brimming over with flowers hung from the roof's eaves and tables covered with pots filled with plants in bloom dotted the entrance at the end of the building. Lia exclaimed, "I told you it's fantastic!" A mayhem of people and a vast array of goods soon engulfed us-the market vibrated with the hum of 


\section{Heritage Building Markets}

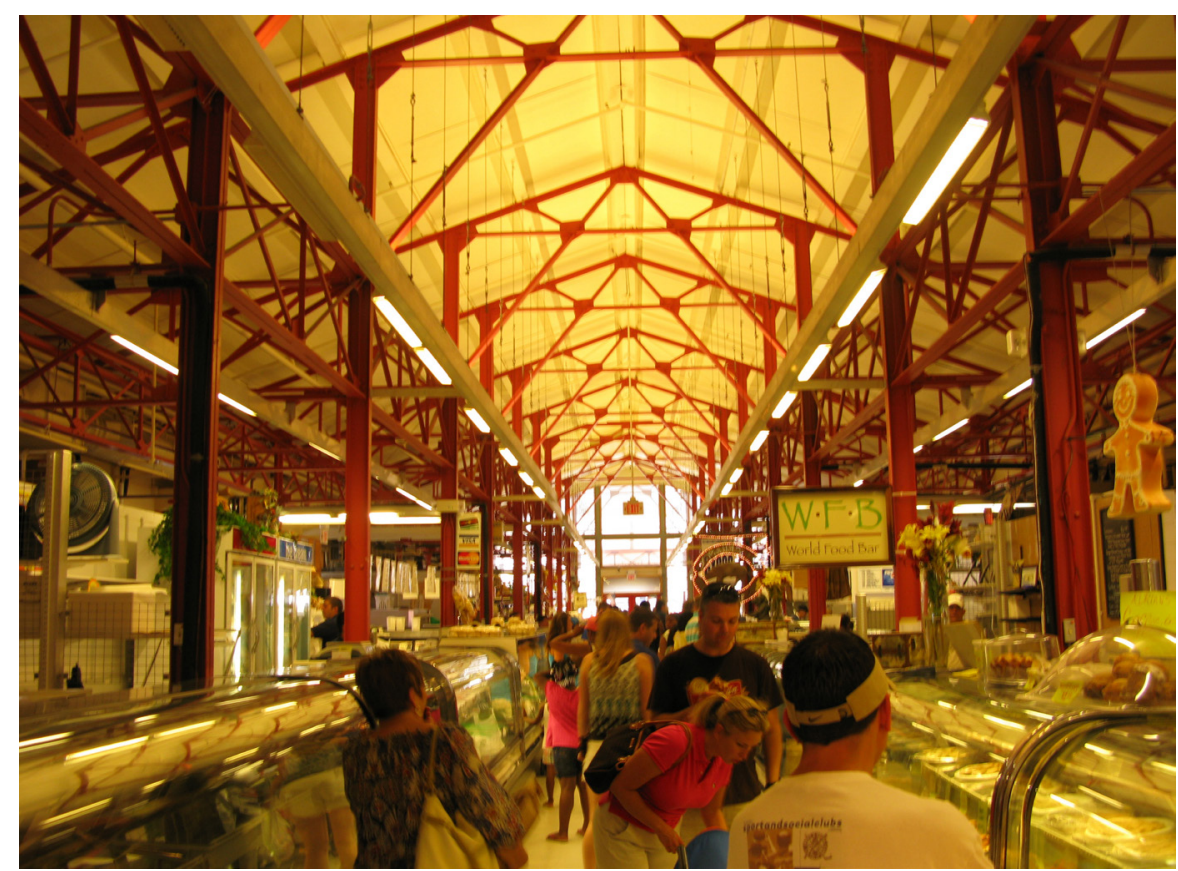

Image 2.13 Distinctive Tuscan red Fink trusses in historic market building.

people's voices and occasional exclamations of "Oh, look at this!" or "Ooh, something smells good." Under the gabled metal roof, colorful, fragrant flowers lined the entrance to the interior of the market hall. Just beyond the double glass doors, the enclosed voluminous space bustled as people maneuvered up and down the central aisle, flanked by refrigerated cases full of meat, poultry, cheese, and other attention-grabbing, freshly made goods. Despite these sensory distractions, my eyes were drawn upwards to the lightweight iron trusses painted Tuscan red (see image 2.13). These modified Fink trusses gave the interior of Findlay Market its distinctive character at the time of its construction in 1852 and still distinguish the market today. While wrought iron framing was prevalent in railroad bridges of the nineteenth century, Findlay Market was the first instance of a public market using this technology in the United States.

As the lifestyle of Americans underwent drastic changes in the ig6os, so too did the shape of their cities. Government officials destroyed the historic identity of many American cities through the removal of significant public buildings, particularly civic ones, including public markets. Ohio's government demolished the Sixth Street Market, built in I895, 


\section{Chapter 2}

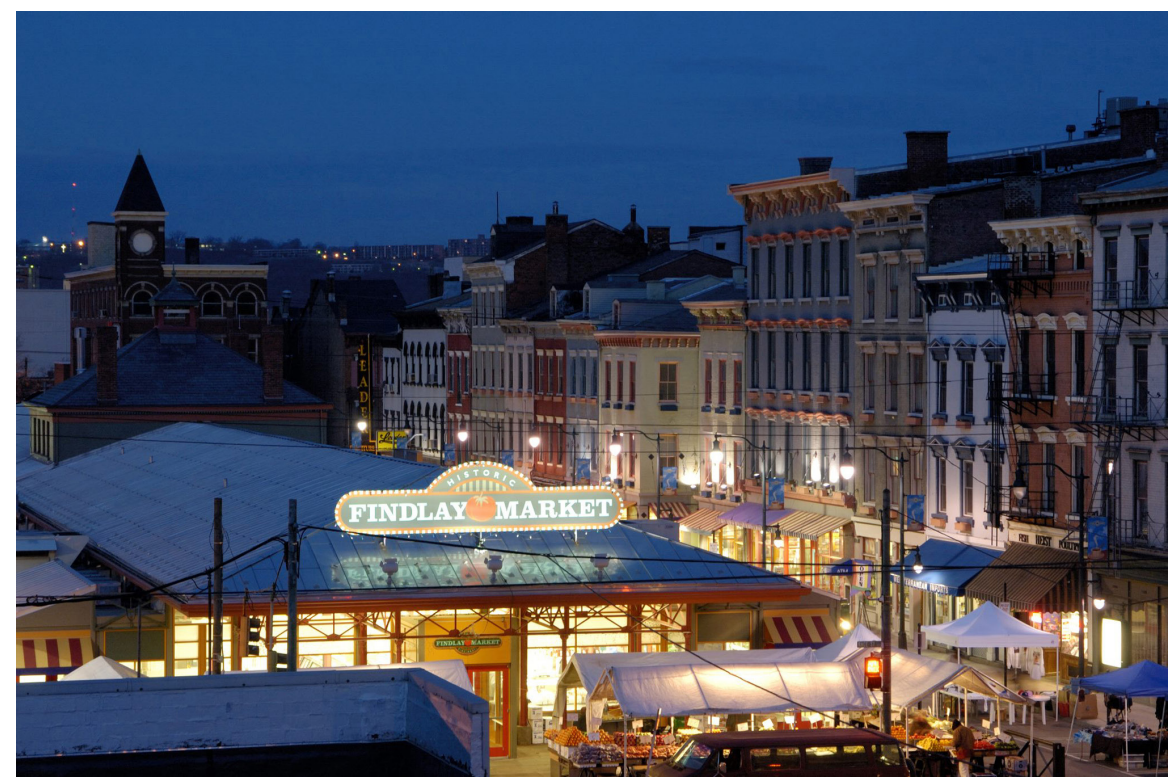

Image 2.14 Findlay Market thrives in Over-the-Rhine neighborhood.

to make way for the Sixth Street approach to I-75 Mill Creek Freeway. Findlay Market had prevailed, but was in serious jeopardy. Thankfully, many Americans had grown increasingly concerned about losing beloved historic buildings, and in ig66 the U.S. Congress adopted the National Preservation Act, federal legislation that protected landmark buildings and neighborhoods.

Preservationists and urban activists in Cincinnati recognized Findlay's notable but fragile existence, and rallied to obtain its entry into the National Register of Historic Places in the early i97os. The market's geographic location among architecturally significant buildings proved essential in attaining historic designation status; its surrounding neighborhood, Over-the-Rhine, consisted of 950 structures largely built by German immigrants between I86o and igoo. According to the Historic District Designation Report, "Over-the-Rhine's collection of commercial, residential, religious and civic architecture is one of America's largest and most cohesive surviving examples of an urban, nineteenth century community." "6 Findlay Market, supported by its densely populated neighborhood, continued to thrive into the twentieth century. The abundance of notable late nineteenth-century Italianate architecture in the area (and in fact, the United States) led city leaders to rally once again to gain designation as a National Historic District in 1983 , and 


\section{Heritage Building Markets}

the Over-the-Rhine North Local Historic District was founded in 200 . The conservation guidelines describe this district as "a dense urban area that displays a visual continuity conveying a sense of time and place." ${ }^{17}$ This physical continuity results from the repetitive use of brick as the dominant exterior building material and the vertical proportions of the building's volume, as well as its doors and windows. The openings are accentuated by flat or arched pediments overhead, and projecting eave brackets supporting an impressive overhang emphasize the roofline. The modulation of the individual buildings results in high frequency of entrances to shops on the ground floor with extra-tall windows. Intermittently, buildings constructed in the more ornate Queen Anne Revival or muted Greek Revival styles punctuate the consistency of the Italianate structures.

The distinctive attributes of the neighborhood supporting Findlay Market reminded me of what Lia Braaten told me during my first visit. She remarked, "Findlay's history, its cohesiveness, and the sense of community that you feel when you shop here makes it special." (see image 2.I4) Her sentiment is echoed in the market's website:

No matter how your Findlay Market story starts, we all share the pleasure of carrying on a tradition that is a century and a half young. Each week, we gather in this living landmark to shop, socialize, and reconnect with the people who grow and purvey our food. Together, we have embraced a shopping experience-with the emphasis on experience-that is simply irreplaceable. The quality and value of the products available is unparalleled; the diversity of our customers and the democratic approach to service is unique in the region. Findlay routinely attracts the most socially, economically, racially, and ethnically diverse crowds found anywhere in Cincinnati. Shoppers surveyed since 2007 have registered over rgo zip codes. An estimated I,o86,580 shopping visits were made to Findlay Market in 20I $3 .{ }^{18}$

Five years later the website states that "an estimated I.2 million shopping visits are made yearly-making this historical landmark the

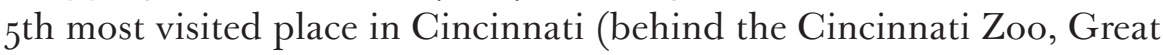
American Ball Park, the Museum Center, and a Casino)!"

Signs of the racial and ethic heterogeneity of its patrons can be seen in the variety of food-related events and activities that align with 


\section{Chapter 2}

regional identity. Cincinnati is known for its unique recipe for chili that includes chocolate and is served over spaghetti (though, as I found, recipes vary). For over a decade, Findlay Market has held its annual chili cook-off competition in late January inviting vendors and residents alike to submit theirs for tasting. Other events align with local customs or offer cultural enrichment. The annual opening day parade (of Cincinnati's Reds baseball season) ends at the market and includes marchers representing the city's mix of residents from diverse backgrounds and origins. During the month of April poetry readings happen every Sunday to celebrate National Poetry Month.

On a return visit to Findlay in 2005, I entered through the bell tower that joins the north and south wings, each I5o feet long. The market opens each day with the ringing of the bell (relocated from Cincinnati's Pearl Market in r934). I searched out the J. E. Gibbs Cheese stall among the string of uniformly sized stalls, which measure ten feet by fifteen feet. Gibbs's stall stands out through its display of tools: a butter churn, a butter tub, a manual cheese slicer, and a balance scale. Sturdy wooden boxes used for transport enhance the visual appeal of the array of cheeses on show in the four-foot-tall and three-foot-deep glass-covered case. These instruments of the trade date back to when Jeff's great-great-grandfather, James, opened at Findlay Market in I922. The various forms of cheese-balls of mozzarella, logs of chevre, and rounds of Brie-also act as visual markers in giving identity to this purveyor.

Next to Gibbs's stall stood another long-term merchant, Charles Bare Meats, which opened in rgog and remained family-owned until 1995, when Neil Luken purchased it from third-generation owners Tony and Joe Bare. Neil Luken Meats continues to offer a full line of high-quality meats at a fair price. This stall gains its identity initially through five- by six-inch signs with "SPARE RIBS" written in bold red letters at the top, and "\$2.29 lb." written below in black. While the colorful sign first draws the shopper's attention, the color of the meat is the real draw-vibrant hues of bright pink and red indicate freshness. The curved glass case full of meats entices so effectively that on my own visits, I've even contemplated the "trotters"-pig's feet-if only for a moment.

Luken had worked at his brother's Findlay fish shop starting at twelve years old. He later went to college and became an accountant, 


\section{Heritage Building Markets}

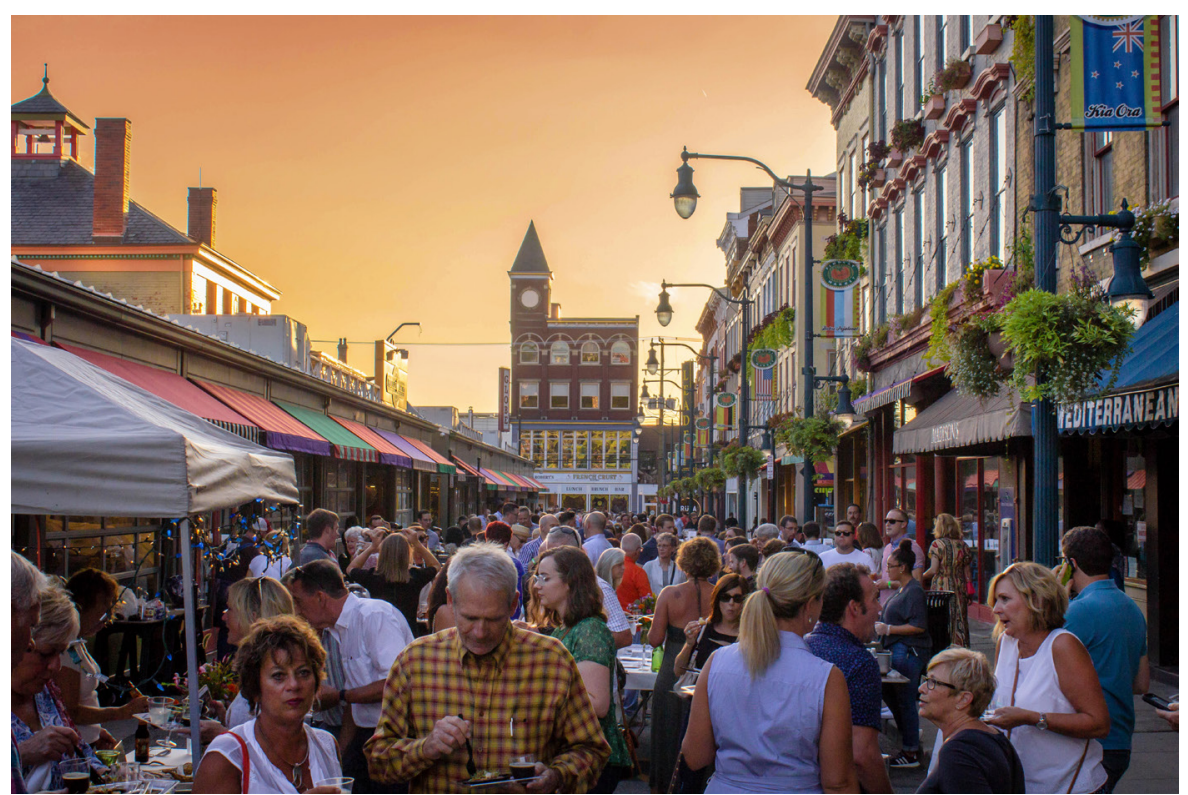

Image 2.15 Adjacent buildings house food-related businesses.

but returned to the market three years after graduating because making fresh wholesome food and selling at Findlay Market "was just in his blood." Neil chooses to make his living at the market because he says the atmosphere can't be found anywhere else in Cincinnati.

When Luken purchased Charles Bare Meats in I995, Findlay Market needed major repairs. The last significant renovation had happened in $1973^{-74}$ as part of the federal Model Cities program, but decades of subsequent neglect had left these century-old structures in a sorry state. At last the government and the people came together in the rggos to save Findlay Market. In 1995 Cincinnati's Department of Economic Development and Department of Public Works commissioned a master plan for revitalizing the market and its surrounding buildings. ${ }^{19}$ Adopted in December of that same year, the plan guided business development through the Corporation for Findlay Market, a private nonprofit management organization founded in 2000 to lead the effort for renewal of the market building and district. Between 1995 and 2004 the City of Cincinnati invested more than \$I million in the market's revitalization. For the renovated Findlay Market to be successful, however, it was clear that the buildings in the surrounding neighborhood needed major reha- 


\section{Chapter 2}

bilitation to address blight and building vacancies. In 2006 Cincinnati City Council named the Corporation for Findlay Market its preferred developer for thirty-nine city-owned properties near the market.

Today, the neighborhood surrounding Findlay Market embodies renewal and liveliness; brightly colored windowsill boxes and hanging baskets with flowers cascade above the sidewalks and visually inviting store window displays attract pedestrians who are there to shop (see image 2.15). Numerous restaurants at the street level offer seasonal outdoor dining that enhances the vitality of the area. Streets surrounding the market-Race, Elder, Elm, and Essen-house food-related shops with large storefront windows displaying delicious-looking local, specialty, or international fares. Churchill's Fine Teas entices passersby with displays of teacups, tins of tea, and tea ware-some vintage and rare. The shop offers teas from around the globe, hence the shop owner's program, "Learn About Tea, Learn About the World." Apartments in the upper levels of the three- and four-story brick buildings provide residents with easy access to an array of fresh, nutritious food at all times of

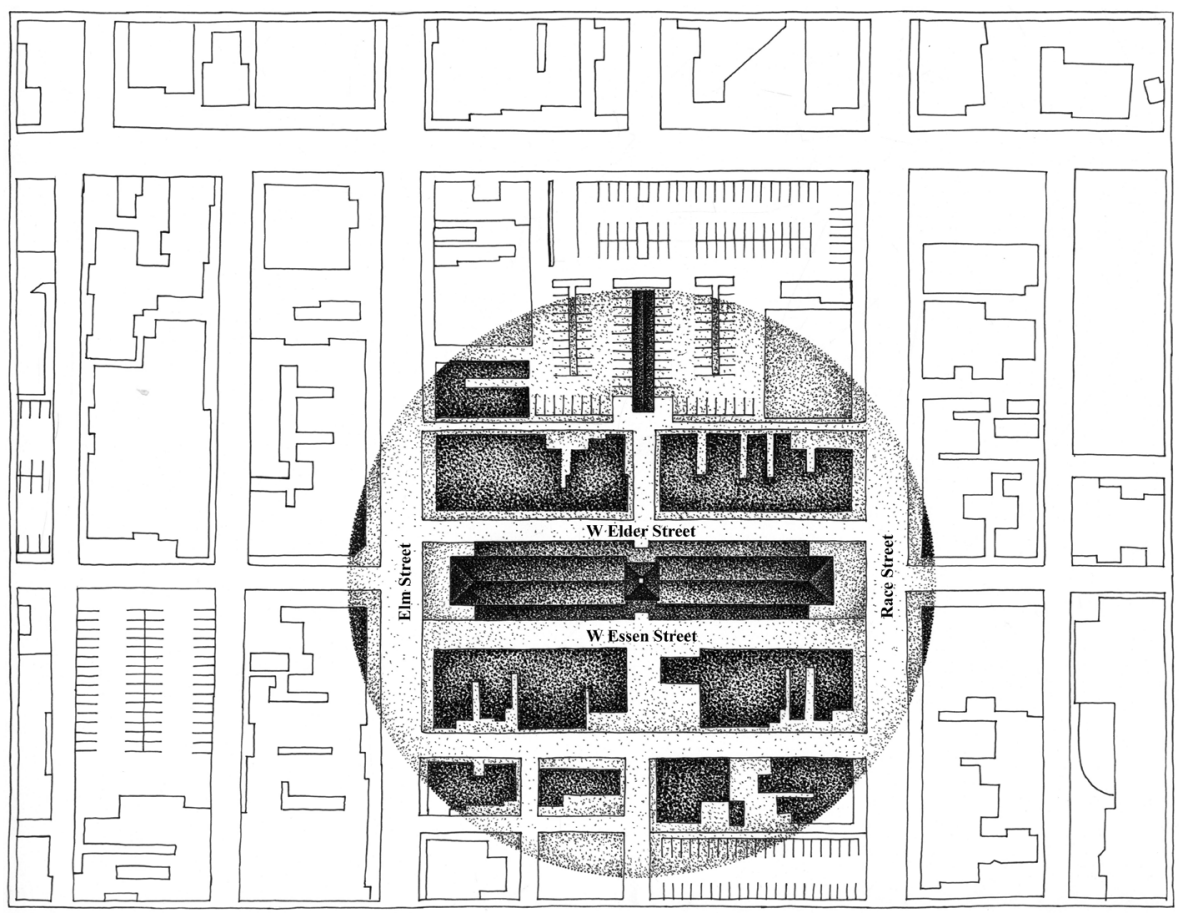

Image 2.16 Diagram showing 500-foot radius of Market District (Findlay is oblong shape at center). 


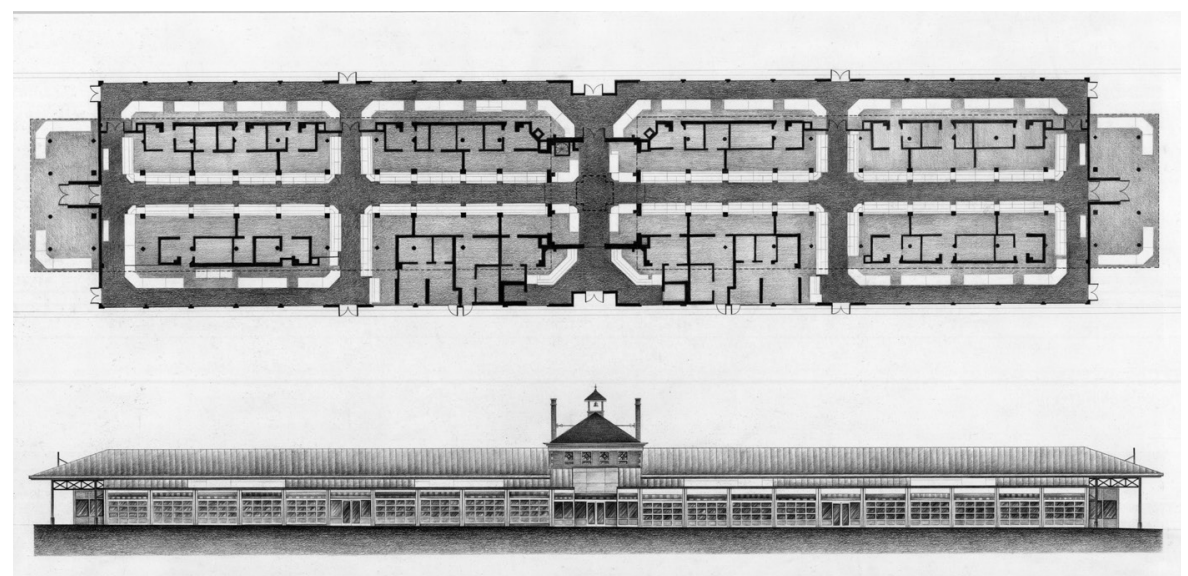

Image 2.17 Floor plan and elevation drawing of renovated market building.

the day. In fact, Findlay's presence goes beyond the building itself, and extends to at least ten surrounding blocks within a ten-minute walk (a quarter-mile walking distance); this area is now named Findlay Market District (see image 2.16).

The leadership of Findlay Market has reached out to low-income, underserved populations in a number of ways. In 2016 Findlay Kitchen opened one block south of the market building on Elm Street. This new facility, located in one of the refurbished historic buildings, is a selfdescribed "nonprofit food business incubator" that supports low-income and minority food entrepreneurs hoping to "start, grow, and scale their business." ${ }^{20}$ Aspiring food entrepreneurs have access to eleven affordable professional kitchens with commercial-grade kitchen equipment. Findlay Market leadership has also established community gardens and accepts SNAP benefits. The impact of the urban farm plots in neighboring communities is discussed in more detail in Chapter 5 , as it has beneficially altered the way of life and living for inner-city youth and underserved populations, which is one of the particular focuses of that chapter. The market's SNAP Plus program began in 2007 and, for every visit, matches up to $\$$ ro in SNAP money, redeemed using an Ohio Direction Card-this state's name for its Electronic Benefit Transfer (EBT) card. In 20I4 a program, Produce Perks, began to incentivize the purchase of fruits and vegetables. Communications Director Kelly Lanser states that the magnitude of benefits is around $\$ 20,000$ per year for the vendors selling under the pavilion and pop-up tents; building 


\section{Chapter 2}
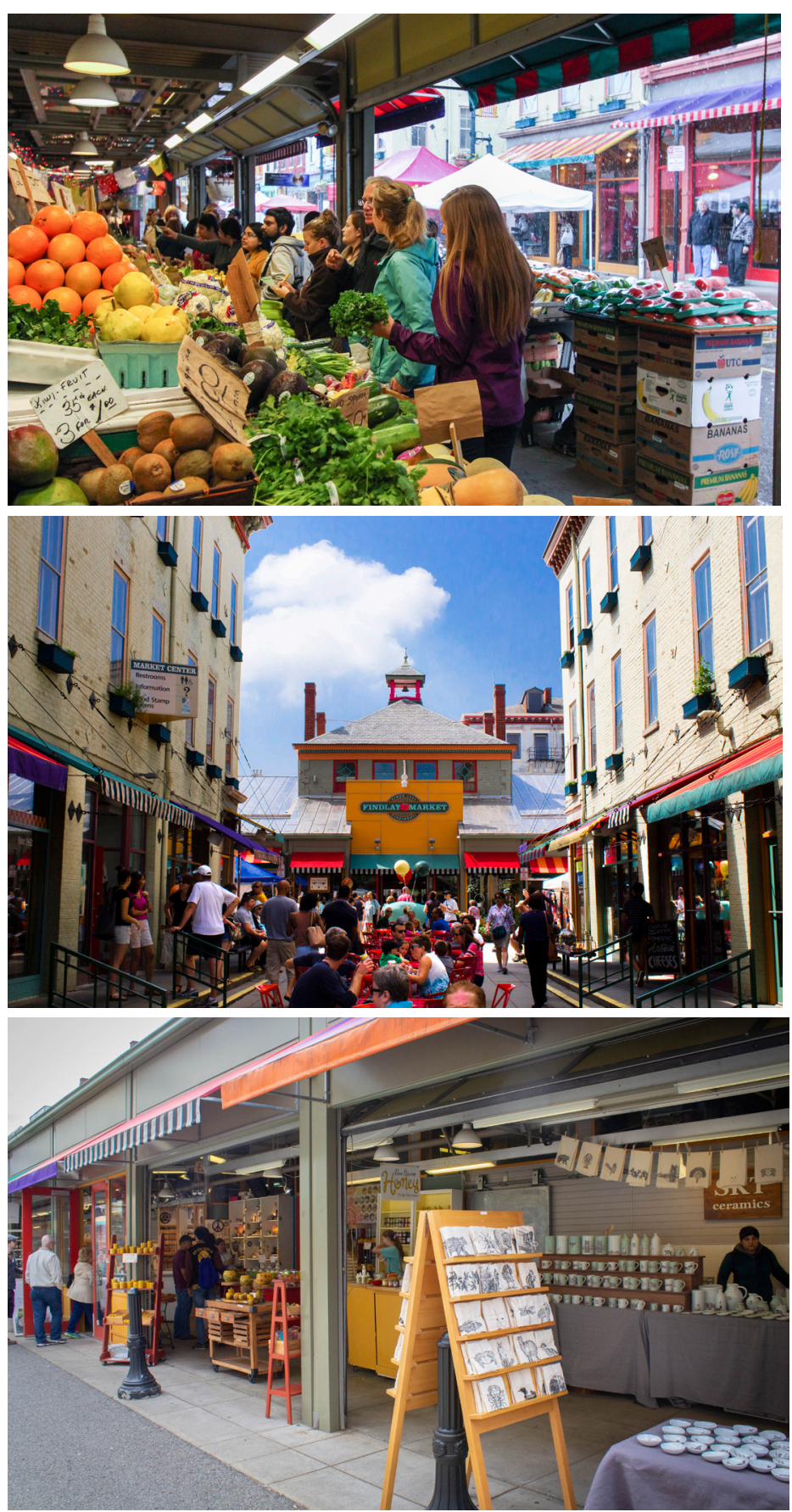

Image 2.18 top. Vendor displays in perimeter stalls.

Image 2.19 middle. View of new stalls encompassing perimeter of historic building. Image $\mathbf{2} .20$ bottom. Vendor displays extend into the street. 


\section{Heritage Building Markets}

merchants have their own individual accounts capable of redeeming SNAP monies via EBT cards. Locally headquartered Proctor and Gamble provides generous support (but not all funding) for SNAP Plus.

Years after my first visits to Findlay Market, I was curious about the details of the market building's and neighborhood's renovations, so I contacted Glaserworks, the architecture firm responsible for the restoration and expansion of Findlay Market, and spoke with architect Andrew Schneider. While the rehabilitation respects the original building interior and structure of city civil engineer Alfred West Gilbert, Glaserworks made significant changes to the exterior of the building (see image 2.17). They opened up once-solid walls between columns and added new shallow stalls around most of the perimeter of the building, facing onto the streets with glass walls that open, rolling up like garage doors. The scale of building components-doors and window frames, columns and gutters, awnings and signage-augments the cornucopia of displays visible from outside the market building (see image 2.18). The bright hues of these architectural elements amplify the colors of the food and goods (see image 2.19). These changes to the perimeter of the market building greatly enhance pedestrian density and visual continuity for a distance of about 200 feet. Although the building does not offer the grandeur evident in DC's Eastern Market, the openness of the building's perimeter provides a sense of connection between market stalls visible from adjacent streets and the outside shops lining those streets (see image 2.20).

Similar to Eastern Market, Findlay's renovation has garnered multiple awards for the architectural firm Glaserworks for its high-quality preservation while maintaining its distinctive original design character. ${ }^{21}$

Eastern Market and Findlay Market are two shining examples of how heritage building markets provide distinctiveness to their surrounding neighborhoods more than a century after their founding. Both markets remain vital today, as they continue to serve as gathering places for diverse groups of people and thereby to foster a sense of community and collective existence. I contend that how these formative examples maintain a strong relationship between the physical building and setting within the associated social framework-between place-making and collective meaning-making-arises from the symbiotic relationship of situation, ritual, and fellowship. While each neighborhood differs in 
its particular contemporary circumstances-DC's federal government's dominance versus Cincinnati's racial and ethnic tensions-the building fabric was constructed in the same timeframe of the Victorian era. Synergy between the architecture of the building and the sense of place played a critical part in forging bonds of solidarity among residents over the duration of years and through the routine of their daily lives. 


\section{CHAPTER}

3

\section{OPEN-AIR PAVILION MARKETS}

ح HE REALIZATION OF a permanent open-air structure for my hometown farmers market was a dream of mine that took six years to come to fruition. A municipal parking lot at the corner of Roanoke Street and Draper Road in Blacksburg, Virginia, has been transformed into the farmers market's new home-Market Square Park, a sixty- by ninety-foot grassy area with an L-shaped structure along its northeastern perimeter (see image 3.I). Five nested pavilions made of white oak, heavy timber with brown metal roofs, comprise the structure. Each one steps down a few inches with the slightly sloping terrain, and each one's roof overlaps the next by about two feet. The park, parking lot, and pavilions together cover half an acre in the downtown core.

Blacksburg's Market Square Park sits at the southwestern edge of Virginia Tech's campus, a block from Main Street, the U.S. Post Office, and the Historic I6 Squares Neighborhood (see image 3.2). The new structure officially opened on December 5, 2009. Five inches of snow fell that day, but vendors and shoppers still showed up excited to see and experience the new shelter, which effectively offers protection from all kinds of weather while shopping. At the grand opening celebration in April 20ı, hordes of people filled the park-some stood in conversa- 


\section{Chapter 3}

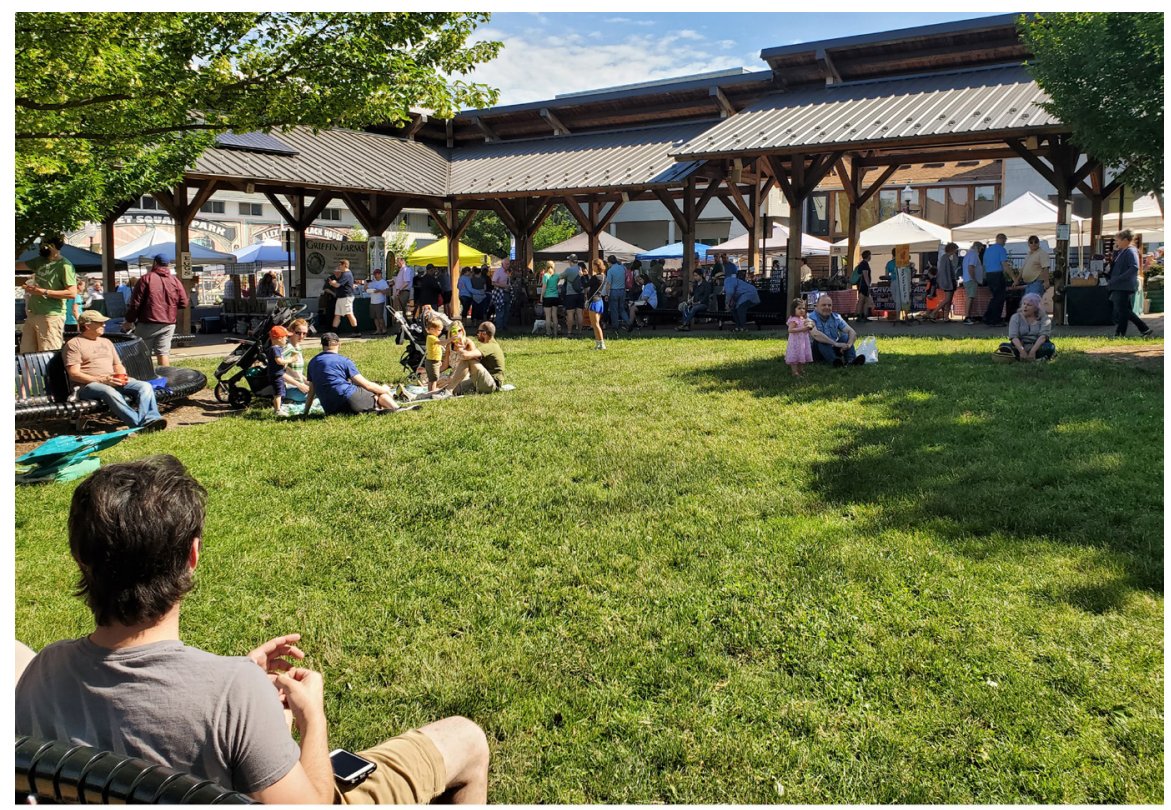

Image 3.1 View of Blacksburg's Market Square Park and pavilion(s).

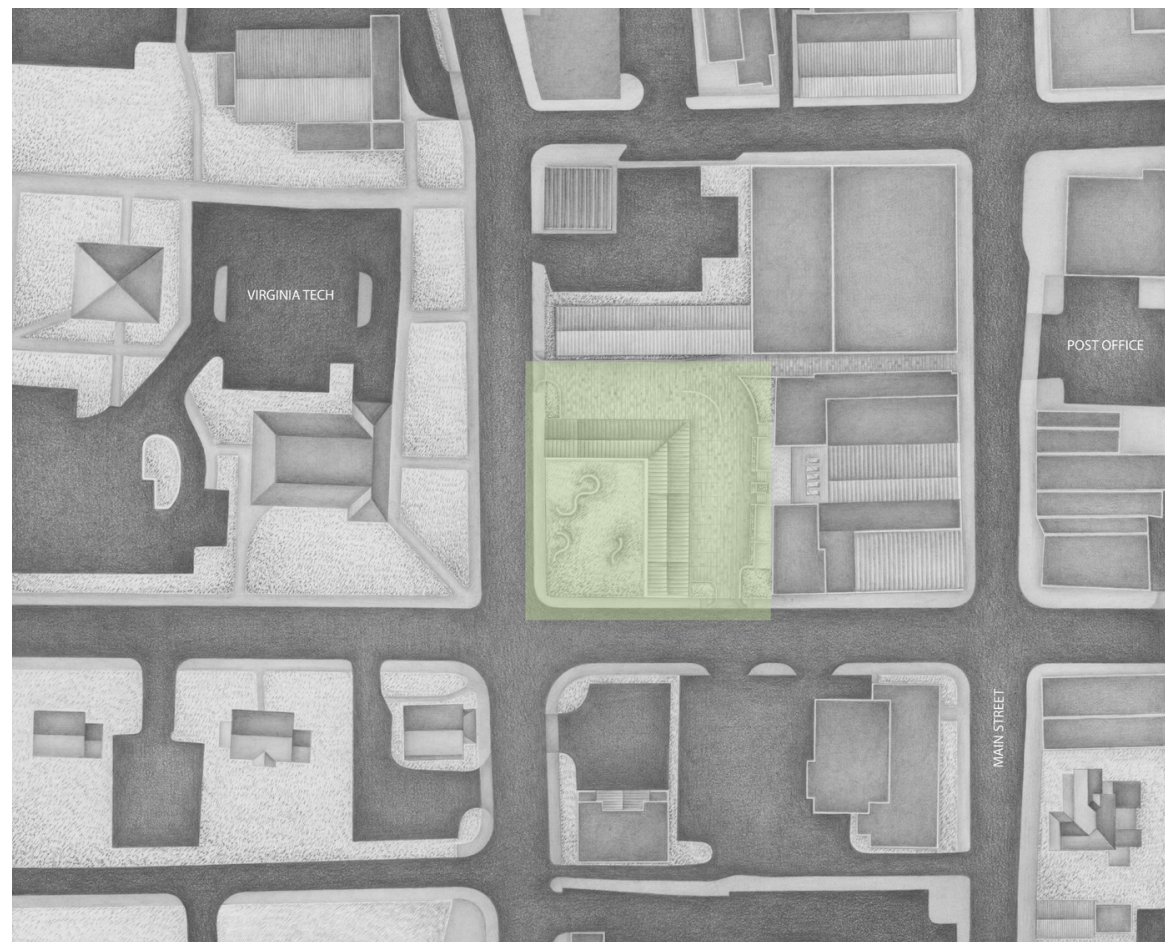

Image 3.2 Plan drawing of Market Square Park nestled between Virginia Tech and downtown. 


\section{Open-Air Pavilion Markets}

tion, others sat on the new curvilinear benches and observed the crowd, and lots of kids ran around in the grass, but most folks browsed the bountiful displays of about two dozen vendors before purchasing the fresh local harvest, meats, and handmade goods. As I sat on one of the benches, I watched the energetic engagement; it was gratifying to see how well the open-air pavilion was functioning, as planned, as a cohesive market space and as a place for community gathering. Over the past decade since its opening, my satisfaction has only grown as the planned and spontaneous use of the open-air pavilion, on market days and non-market days alike, increases each year.

In the nineteenth and early twentieth centuries, towns often built open-air structures solely for use as farmers markets, at the time called "freestanding sheds" or "market sheds." Typically located in the middle of a thoroughfare or on the edge of a town's public square, the market shed consisted of a low-pitched roof supported by multiple bays of brick piers or wooden posts. Builders could quickly and easily assemble this type of structure because the modular bay system was a common construction technique at the time. ${ }^{I}$ Because this type of structure was relatively inexpensive to build (versus the market-house type discussed in Chapter 2) it also fit within the budgets of many more towns and smaller cities. Sadly, none of these centuries-old open-air pavilion markets remain standing today, although we have an abundance of photographs, which can be found in the U.S. National Archives.

In today's urban landscape, open-air pavilions most often reside in public parks or adjacent to public market buildings. While similar to their historic predecessors in materials, size, and configuration, modern open-air pavilions host a multitude of recurring events throughout the year in addition to seasonal or even year-round farmers markets. Most open-air pavilions are single-story structures with multiple entrances to a central open area that allows for flexibility in the placement of tables, chairs, signage, and displays of vendors. Designed to accommodate diverse functions and varying numbers of people, open-air pavilions, by their very nature, promote intimate as well as group interaction. Over time, these structures become an integral part of the community, as natural as a post office or a corner grocery.

The Harris Pavilion, which stands adjacent to the commuter train depot in Manassas, Virginia, maintains a full calendar of free music 


\section{Chapter 3}

events for people of all ages and interests in the community. The Victorian-era-inspired steel pavilion hosts the city's farmers market on Thursdays from April through October, but converts into an ice-skating rink during the winter months.

The Pavilion at Constitution Park in Waynesboro, Virginia, hosts the town's biweekly seasonal farmers market in addition to numerous special events throughout the year. The thirty-five- by sixty-foot laminated bentwood shelter remains popular for all kinds of events due to its adjacency to the South River and Greenway Trail. The annual Virginia Fly Fishing Festival features wine tastings from local wineries in the pavilion while fishing enthusiasts browse tables overflowing with gear and guided tour brochures in a temporary pop-up canopy set up next to to the structure.

A smaller but no less elegant steel structure known as the Fifth Third Pavilion located in Cheapside Park in Lexington, Kentucky, hosts its farmers market on Saturdays, April through October, in tandem with the weekly community gathering event simply called Artist's Market and sponsored by Downtown Lexington Corporation.

In Little Rock, Arkansas, two open-air pavilions adjacent to the Ottenheimer Market Hall host the city's biweekly farmers market, which originated in 1974. The contemporary pavilions are part of the River Market District that encompasses ten blocks and includes art galleries, shops, restaurants, and the main branch of the Central Arkansas Library. The construction of the open-air structures in a once-dilapidated area generated the redevelopment of buildings and land fronting the Arkansas River. The two pavilions, comprised of laminated wood trusses supporting a metal roof, offer 6,8oo square feet of space-plenty of room for twenty vendors during the farmers market. A fifty-eight- by forty-foot park with a dozen trees and a few benches joins both pavilions at the midpoint of Market Hall. Together, River Market District and Riverfront Park provide a multitude of community gathering places for civic engagement.

Although smaller in scope than Little Rock's market, another open-air pavilion market in Ithaca, New York, is also notable for its pivotal role in the transformation of underutilized land along the banks of an inlet from Cayuga Lake into the destination known as Steamboat Landing. From its inception in 1973 on the west side of the city, Ithaca 


\section{Open-Air Pavilion Markets}

Farmers Market grew rapidly; it had to move five times before settling into its current location on the north end in 1988 . The following year construction began on its timber-frame pavilion, and, remarkably, it was all built by volunteer labor. Comprised of eighty-eight stalls ranging from ten to twelve feet wide by ten feet deep, this T-shaped structure situated in a parklike setting also has served as a community gathering place for hundreds of weddings, and for the past several years, has hosted the premiere concert of the decades-old Ithaca Festival held in early June.

In the remainder of this chapter I take an in-depth look at three open-air pavilions whose identity is derived primarily from the fact that they host a local farmers market. All three pavilions were built within the past dozen years: two in small Virginia cities, Abingdon and Covington; and another in Durham, North Carolina. Each one began over three decades ago as a pop-up canopy market in a public parking lot and persisted through its local economy's transformation. The pavilions also serve as focal points for community events on non-market days within their respective municipalities.

In the counties surrounding Abingdon, the demise of the tobacco farming industry beginning in the ig8os severely jeopardized the livelihoods of residents. However, by the mid-I9gos organic farmer Anthony Flaccavento was inspired by the idea of transforming the region's tobacco-producing agricultural land into food-producing farms that would offer environmental sustainability and food security for the region. To accomplish this feat, he founded the grassroots nonprofit organization Appalachian Sustainable Development. In support of Flaccavento's proposed land use conversion, then Director of Planning Al Bradley advocated for an open-air pavilion as a visible, permanent place for the farmers and other local food producers to sell their harvest and selfmade products. Their efforts proved successful; Abingdon's farmers market as it stands today remains a formidable force in the region's local food network and sustainable agricultural economy.

Similar to Abingdon, Durham's market resides in its current location at the Pavilion in Durham Central Park because of the demise of the tobacco industry-the pavilion sits on land that once warehoused tobacco when it was a driving force of the local economy. However, the Durham Farmers Market began as an extension of a local food co-op, 


\section{Chapter 3}

which would set up pop-up canopies in the parking lot of the Durham Bulls baseball stadium. Today, the pavilion serves as an incubator for new businesses; it hosts the farmers market twice a week in addition to other events year-round.

Covington's new open-air pavilion is a remarkable accomplishment of another sort. Local businessman Jacob Wright teamed up with architects Keith and Marie Zawistowski, who lead seventeen Virginia Tech architecture students to fundraise, design, and build the structure within a year. The new pavilion that now hosts the city's farmers market sits alongside historic Route 6o. Also known as the Midland Trail National Scenic Byway, the highway extends 315 miles from Charleston, West Virginia, to Hampton Roads, Virginia. The Covington Farmers Market's ideal downtown location alongside the historic highway has helped it become a well-known destination for fresh, healthy food, and an anchor for community events and civic engagement.

The consistent presence of open-air pavilions is paramount to communities experiencing the ritual and fellowship gained at a farmers market. The story of these three cities' markets proves how well open-air pavilions function as farmers markets and community gathering places. Notably, the design of each pavilion is as unique as the place and the ways in which the community embraces it. Discovering each pavilion's impact beyond market day validated my understanding of their civic importance-whether full of activity on market day or almost vacant, they beckon passersby to engage.

\section{Abingdon}

I heard about Abingdon's pavilion market several years ago from Jenny Schwanke, a vendor at my hometown market in Blacksburg. Although not an architect, she described Abingdon's structure as though she were one, verbally painting a picture of its open-air, L-shaped, wood-frame pavilion with a dark green metal roof-highlighting its distinctive feature at the bend in the L-shape of the roof where a distinctive six-foot tall rooster weathervane rests on the peak of the double-height, hip-roofed segment. As part of its art initiative, the city's leaders commissioned local blacksmith Bill Gable to craft the weathervane as a way to signify the pavilion's primary identity with the city's farmers market (see image $3 \cdot 3$ ). 


\section{Open-Air Pavilion Markets}

Image 3.3 right. Artist Bill Gable proudly stands by the weathervane he crafted for Abingdon Farmers Market.

Image 3.4 below. Plan drawing showing the farmers market pavilion one block south of Main Street.
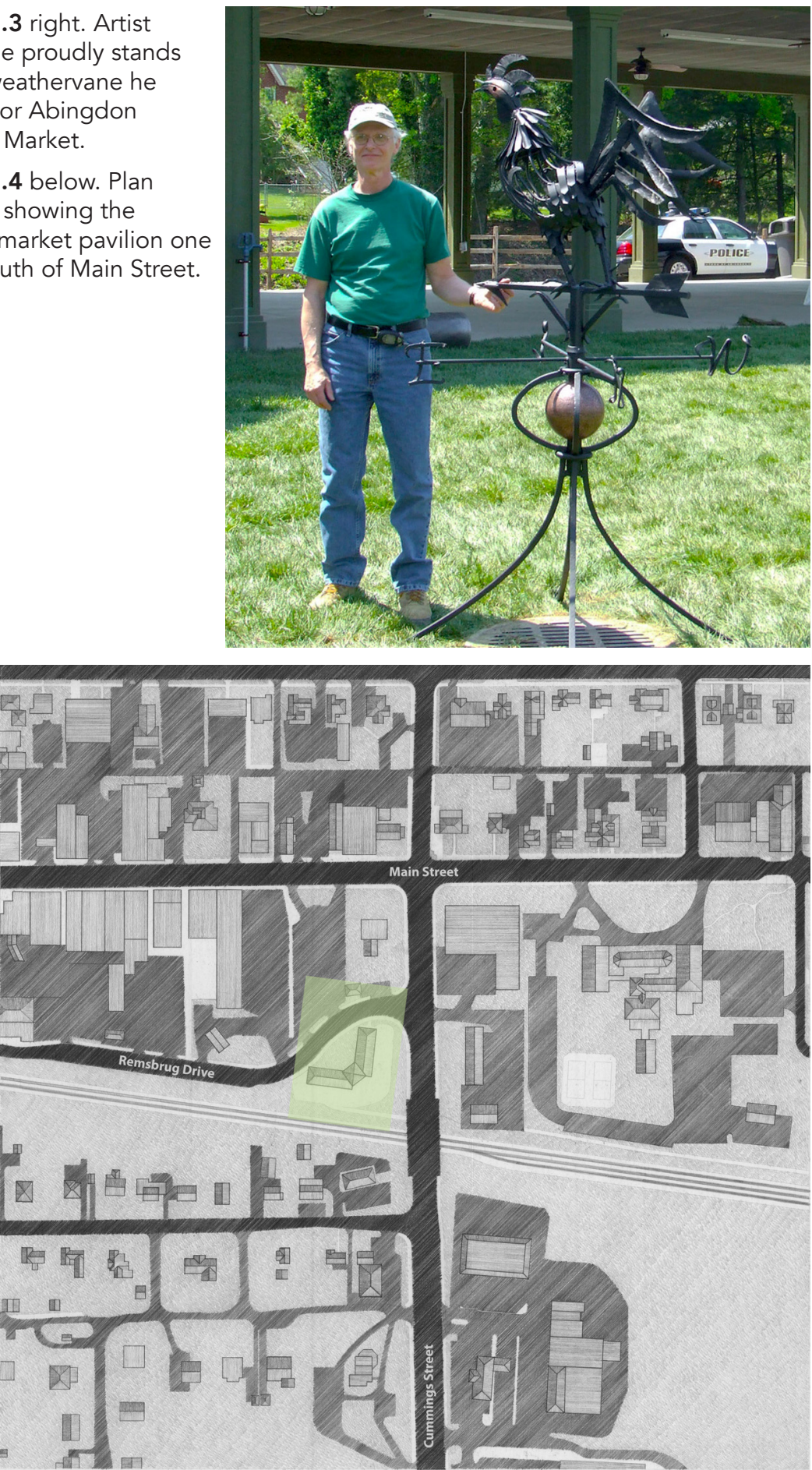


\section{Chapter 3}

With Jenny's vivid description of Abingdon's market lingering in my mind, I decided to pay a visit one spring Saturday morning. After the hour-and-a-half drive down I-8I South, I exited onto Cummings Street and approached the town from the south. As I crossed over railroad tracks, I spotted the rooster weathervane atop the pavilion on my left. A sea of people carrying bags overflowing with veggies streamed out of the end of the light-green-stained-wood pavilion and walked towards a vehicle-packed parking lot across Remsburg Drive. The pavilion sits a few feet below the street level at its entrance from Remsburg. I then spotted a pedestrian bridge close by and headed towards it on a wooden-planked path next to the railroad, hoping to get a view of the market in relation to the downtown. From my vantage point on the bridge, I could see the pavilion nestled downhill, a block from Main Street, which is lined with banks, restaurants, art galleries, shops, and the famous Barter Theater a few blocks from the Mary Washington Hotel (see image 3.4). I could also see that residential neighborhoods with high-quality houses bordered Main Street. The very fact that the pavilion is situated where people live, work, and conduct their daily or weekly activities is vital to its role in fostering community and civic identity through recurring and varied use throughout the year.

I then headed back to the market and entered from the railroad entrance. As I did so, I took note of its architecture and setup; vendor displays flanked both sides of the fifteen-foot-wide center aisle, and the cross-section of the pavilion looked to be about thirty-five feet (see image 3.5). One-foot-square columns spaced every twenty feet along the perimeter accommodated two vendor displays between columns. The pavilion hummed with conversation among shoppers and vendors. Each vendor displayed goods in unique ways that gave individual identity to each stall. To the left of the aisle stood one display with heaps of produce next to a table with only eggs, and across the aisle sat a table with tubs of salsa stacked as high as my shoulders, adjacent to a two-tiered display of wooden bowls and boards (see image 3.6). Some stalls had a sheer shade cloth behind their display draped like a curtain from a rod spanning between columns, while others had a banner with the farm name hung from the rod. The vendors' personalized displays transformed the repetition and sameness of the stall dimensions and overall uninspired pavilion design, transmitting a balance of cohesiveness and quirkiness. 


\section{Open-Air Pavilion Markets}

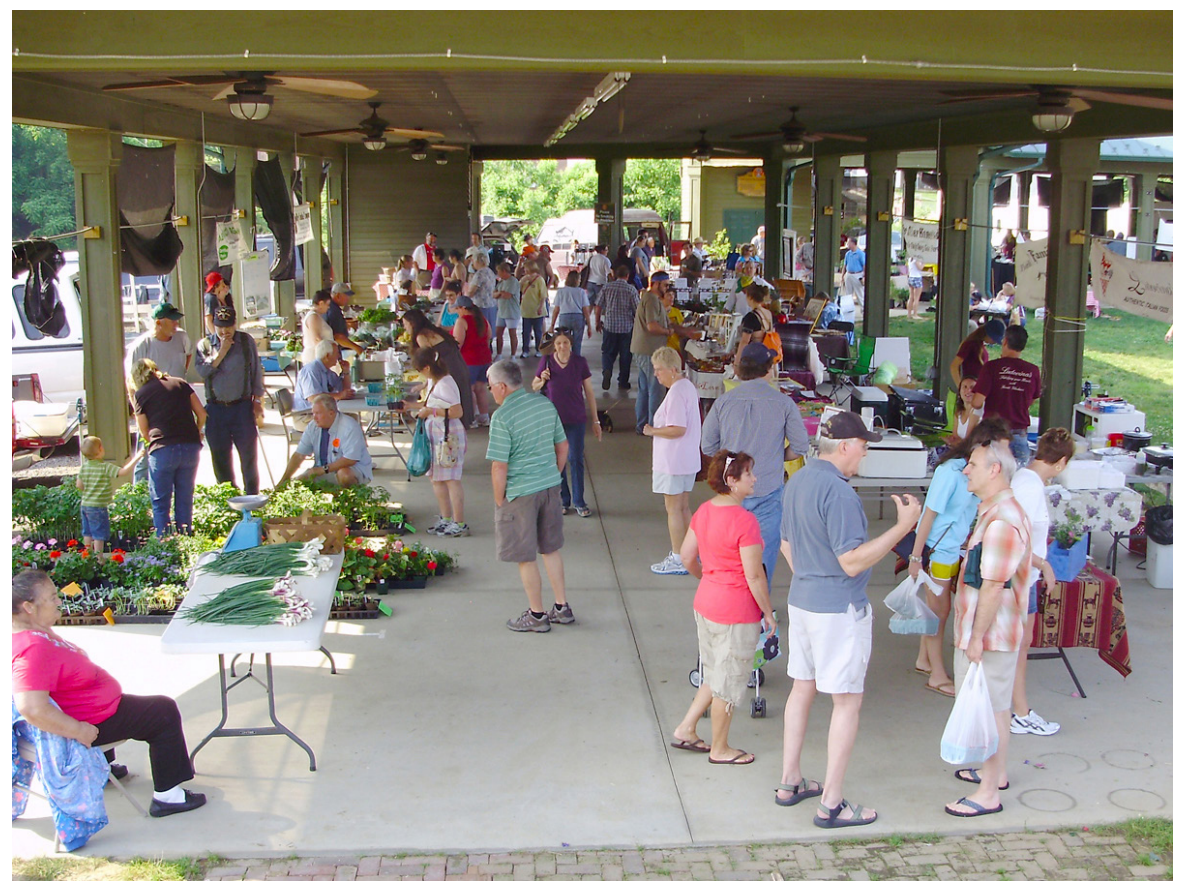

Image 3.5 Lots of activity under the pavilion at Abingdon Farmers Market.

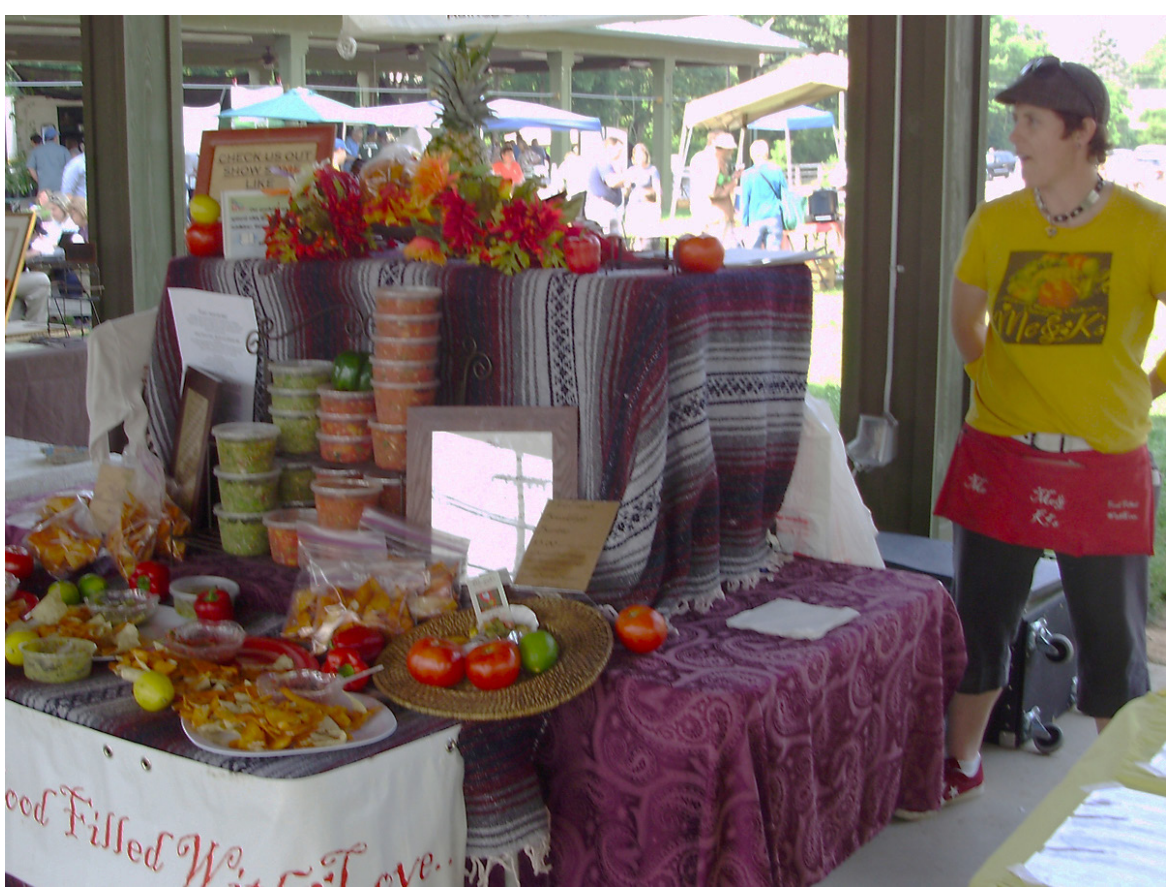

Image 3.6 Stacks of salsa distinguish this stall. 


\section{Chapter 3}

A flurry of activity at the bend in the "L" caught my attention, where a group of people stood around a table covered with t-shirts, tote bags, and a sign. All of these materials promoted the market's acceptance of SNAP (Supplemental Nutrition Assistance Program), the federal government's food assistance program for low-income citizens. The farmers market began accepting SNAP EBT in 2010 thanks to the pioneering efforts of Sara Cardinale, Abingdon's market manager at the time (whom I would soon meet). Sara initiated a relationship with Appalachian Sustainable Development, which is qualified as an agent to distribute USDA-funded SNAP Double Value monies. In 2013 Tamera McNaughton, Agriculture Program Manager at ASD, reported that \$Io,ooo was distributed to shoppers at seven farmers markets in the vicinity-Norton, Big Stone Gap, and Independence in Virginia and Greenville, Jonesborough, and Johnson County in Tennessee. Notably, Johnson County Farmers Market located in Mountain City has 33 percent of its residents receiving government assistance for food. ${ }^{2}$ At Abingdon Farmers Market in 2013, \$5,300 was given out under the Double Dollar Program, which matches up to \$Io per SNAP household each market day. When that number declined to $\$ 2,086$ in 2014, ASD stepped up efforts to broaden awareness of the program as well as to assist in access to the market. ${ }^{3}$

Ed Davis, the man behind the table with the SNAP sign, smiled broadly when I told him of my research into various types of farmers markets as community gathering places. Ed's description of his involvement with Abingdon's market validated many of my conclusions regarding a farmers market's vital role as a community gathering place. Ed, a professor at nearby Emory and Henry College, is a rural geographer whose research and outreach involve connections between agricultural sustainability, place-making, and meaning as they relate to farming and home gardens in the American Southeast. One of his comments, among others, that stuck out concerned the disparity between the wealthy lawyers who lived in the region due to its role as a county seat, and the struggling farmers due to the desmise of tobacco. He said the farmers market provided common ground where people of varying incomes could support the local economy and livelihood. We chatted for a bit and, realizing we had much to discuss regarding our mutual interests, exchanged contact information so I could resume exploring the vendors' displays. 


\section{Open-Air Pavilion Markets}

A bucolic image of cattle grazing on rolling hills with "Roffey Cattle Company" printed on a banner stretched between two columns caught my gaze. Behind a single, sparse table with a cooler below and plastic jar labeled "chicken raffle" on top stood a young man wearing a Ron Paul t-shirt and a cap: he introduced himself-Dwayne McIntyre, the farm manager. During conversation with Dwayne about raising catthe and farm life, I realized another dimension of community that selling at the market offers farmers like him: the balance of the independence that farming affords with the camaraderie that the market provides (the opportunity to meet the people who value what he creates). Dwayne talked about sitting among the herd each morning to inspect their health, describing how he observes the cattle to see if one may have a limp because (as he explained) thistles are tough on the cows' hooves. He shrugged off the demands of twelve-hour workdays, six days a week; a new norm for him over the past few years in comparison to his eighthour days as a commercial painter in Philly. He said, "painting was just a job, and not as fulfilling as farming," which he extolled as the best way of life for him-one that lets him "create something while feeling part of a larger community." 4 Dwayne explained how selling at the farmers market allows him to befriend the people who eat and appreciate his products and make connections with people who share his interest in healthy food production.

Stepping back from Dwayne's display, I felt a waft of warm air coming from the ceiling. I looked up and saw a row of a six swirling fans on either side of a continuous strip of fluorescent light fixtures running the entire length of each section of the pavilion-not visually appealing to me as an architect, but functional; the breeze comforted me on the hot, muggy day (see image 3.7). Suddenly, I heard the bellowing of a shopper's voice, "What is a chicken raffle?!" as he gestured towards the plastic jar on Dwayne's table. Dwayne's explanation made me realize another impact of participating in the farming community. He explained that his farm has a stellar reputation for having the best-tasting chickens, and couldn't keep up with demand, in part because they raise the chickens in small batches of fifty to a hundred with non-GMO (non-genetically modified organism) feed. He explained that the "chicken raffle" gives customers the chance to win a free chicken. The proceeds from the raffle go towards a new initiative that he and a few other farmers started called 


\section{Chapter 3}

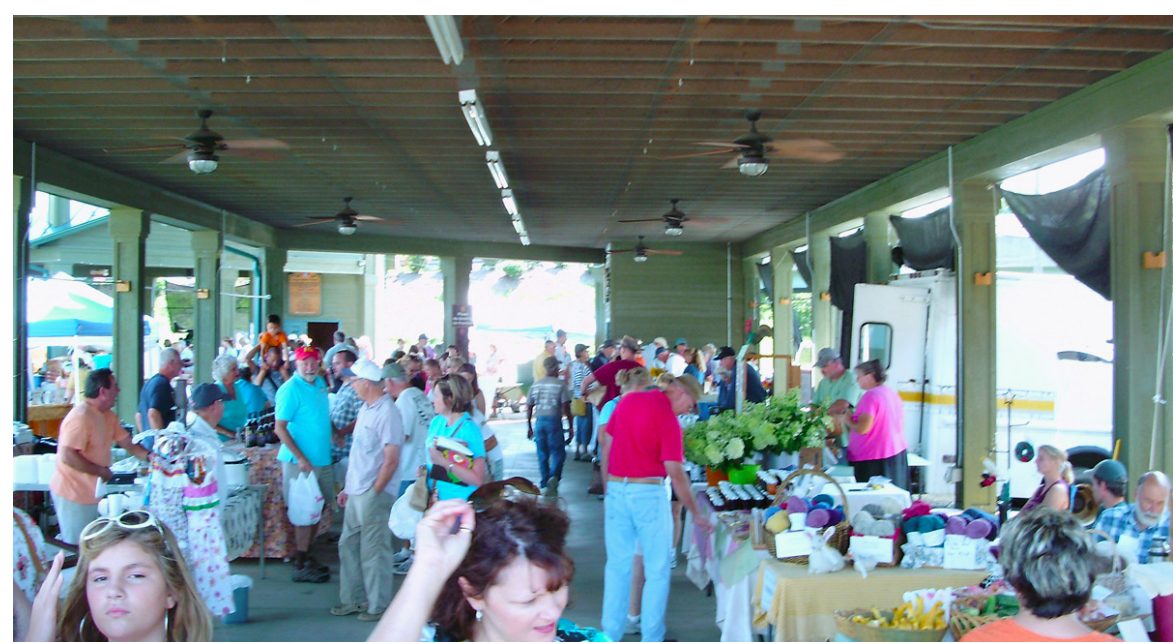

Image 3.7 Ceiling fans and florescent lights are basic necessities.

Appalachian Food Roots Cooperative. The co-op's website allows farmers to post their inventory so that local restaurant chefs can purchase food for delivery to their restaurants. Through this process, Roffey supplies local restaurants with, for example, high-quality duck meat at a price below what food-supplier giant Sysco charges (due to their higher transportation costs). Dwayne remarked, "The co-op is another way the farmers market extends [a] sense of community and meaningful contribution to fresh, healthy, locally grown and produced food." 5

Just as I finished my conversation with Dwayne, Ed Davis approached me with a young woman whom he introduced as Sara Cardinale. Sara and I strolled through the market as she talked about details of her involvement in the market's operations since 2009. She boasted that at the time the market hosted thirty-eight vendors-an amazing number given that Abingdon had a population of only 8,200 at that moment. In 2011 the market divided some spaces in half to accommodate the possibility of more vendors and diversity in products, a change that local farming and fresh food advocate Anthony Flaccavento had pushed for from the outset. We paused in front of Flaccavento's stall display, an L-shaped configuration of tables draped with dark green cloths and covered with bowls of lettuce, spinach, and parsley among overflowing shallow trays and boxes of other produce. The two interns who stood in front of a banner printed with the farm name, Appalachian Organics, informed me that Anthony was in town that day, campaign- 


\section{Open-Air Pavilion Markets}

ing for a seat in the U.S. House of Representatives. (Unfortunately, he did not win the election.)

From Flaccavento's stall, I observed the activity in a grassy, triangular park, where half a dozen vendors had set up ten-by-ten-foot pop-up canopies. The vendors had randomly placed their pop-up canopies without any spatial relationship to one another or the pavilion-the ad hoc displays were uninviting and had me turning back towards the orderly and appealing displays under the pavilion. The crowd inside the pavilion had thinned out as the market hours were close to ending, but one stall was still surrounded by people on all three sides. As shoppers left with their purchases, I glimpsed a handwritten sign reading "Mehl's Bakery," and trays of baked goods sparsely filled with varieties of breads, muffins, and cookies. As the crowd dissipated, I approached the man behind the display, who smiled and said, "I'm David Mehl. How may I help you?" Within a few minutes of conversation, I learned that David and his family had sold baked goods at Abingdon's farmers market since 2004; they'd stayed with the market when it moved from the police department parking lot adjacent to the municipal building a few blocks away on Main Street.

From our brief chat, I realized that Mehl's Bakery perfectly embodies Flaccavento's vision of cultivating a homegrown economy for Abingdon based on the kind of local food production advocated by Appalachian Sustainable Development. Mehl's Bakery demonstrates the power of a farmers market to strengthen relationships even within a

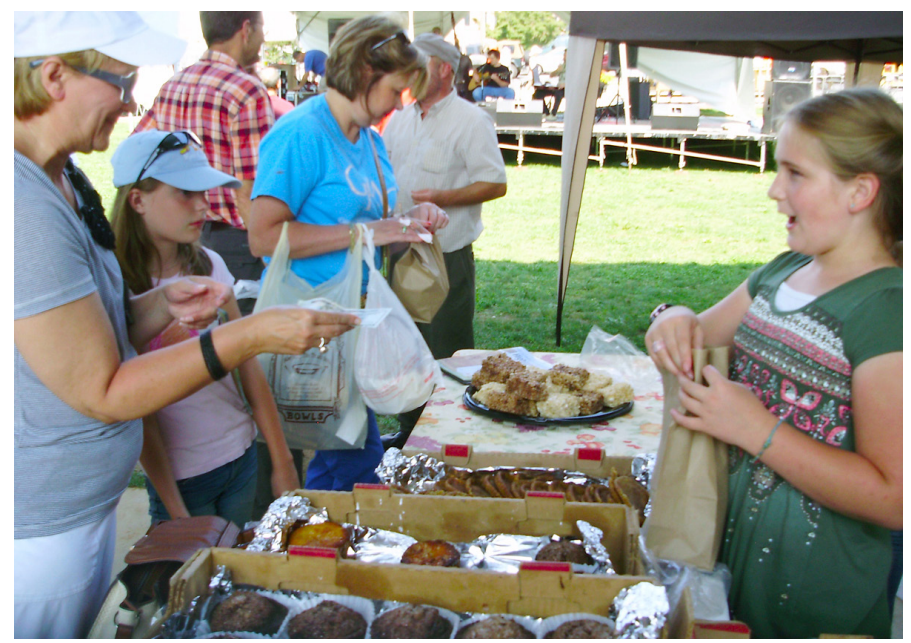

Image 3.8 Rachel Mehl happily serves a customer. 


\section{Chapter 3}

family-the business began with David's wife Kelli's homemade scones and breads. Their daughter, Hannah, makes peasant breads (round breads with cheese or olives); their youngest son, Micah, makes several varieties of muffins; and their youngest daughter, Rachel, bakes cookies and sweet breads. Overhearing our conversation, twelve-year-old Rachel said, "My favorite cookie is ginger, and my favorite sweet bread is pineapple." David pays each of his children by the number of batches sold each week; one recent week, he boasted that he had paid Rachel \$150 (see image 3.8).

As the market closed at 2 p.m., the Mehl family began to pack up what few leftovers they had. I inquired about what they like or don't like about coming to the market. David said, "I enjoy the social opportunity the market offers. On Tuesdays, the market is less busy, so I get to know the people in Abingdon's community." ${ }^{6}$ Hannah added, "It's cool to get to know regulars like friends. They come to market, ask what I have been up to, and they really care."7 David added that, without the market, he would not have come to know certain people he is glad to have met. I thanked them for their insights and their time. As vendors began to sweep the bare concrete floor, I headed for my car, thinking about the role that farmers markets play as incubators of start-up enterprises. They can be crucial in developing and sustaining multi-generational businesses as well as customers that evolve beyond mere agents of consumption.

The sense of community that Abingdon's farmers market enables coupled with a desire for a permanent sheltered space for the farmers market moved former planning director Al Bradley to pursue the building of the pavilion. Until its completion in August 2007, Bradley said, "the market was like a band of gypsies moving from one parking lot to another, and the farmers had no identity within the town." retiring in 2004, Bradley approached Flaccavento and Garrett Jackson, the market's new director of planning, about the necessity for a permanent home for the farmers market. Bradley suggested that Jackson think about the underused parking lot on Remsburg adjacent to the railroad tracks and the Virginia Creeper Trail (another public space that Bradley had worked to establish) (see image 3.9). At a meeting not long after his discussion with Bradley and Flaccavento, Jackson sketched a site plan for a market structure on a napkin and showed it to his colleague, a 


\section{Open-Air Pavilion Markets}

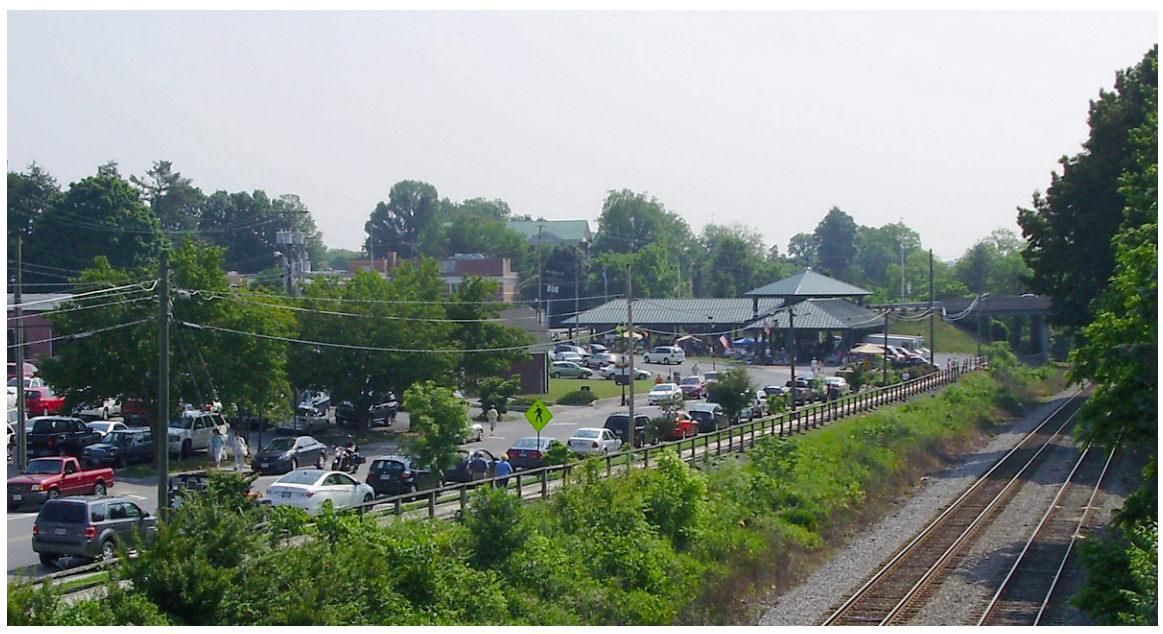

Image 3.9 View of pavilion from pedestrian bridge over railroad.

civil engineer at architectural firm Thompson \& Litton. Jackson's sketch blossomed into a design for a multi-use pavilion, including a small park.

Harry McKinney, an architect and former resident of Abingdon, created official documents for the proposed project, which Thompson \& Litton presented to the city council in September of 2005. After a year of discussion, the project broke ground in late fall 2006 and the new structure opened in August 2007. The speedy realization of the project was in large part due to Flaccavento's leadership in transforming tobacco farming to food production via Appalachian Sustainable Development, which provided access to \$I40,ooo from the Virginia Tobacco Commission. 9 This funding, together with Abingdon's municipal leadership and citizens' commitment and a financial contribution from Washington County's Board of Supervisors, resulted in what Mayor Ed Morgan called:

one of those rare actions that was done by government that seems to have pleased everyone. Our market also helps build community. It is an important gathering place for many people who come to purchase produce, meet friends, have a cup of coffee and sweet roll while listening to local music. ${ }^{\text {Io }}$

Bradley echoes the mayor's statement, saying, "I had worked for the city for twenty-five years and observed that most public projects were met with some level of opposition, but the new pavilion garnered 


\section{Chapter 3}

accolades from everyone" "II-"everyone" including farmers, customers, chefs, foodies, residents, and tourists-the whole community.

\section{Durham}

Durham's farmers market, like Abingdon's, came to fruition in part due to tobacco's demise. Upon my initial visit in November 20I2, I met local community advocate Allen Wilcox, who told me about one winter afternoon in I994 when he and Dr. Curtis Eshelman discussed their dream to revitalize the once-thriving tobacco Warehouse District in downtown Durham. Wilcox and Eshelman had lived in the adjacent Trinity Park neighborhood with their families since the r97os. Over the next half hour, Allen told me the multifaceted story of his engagement with Durham Central Park and how the Durham Farmers Market came to fruition there, in addition to the financial and civic improvements both have brought to the Warehouse District.

The Warehouse District in Durham had gone downhill since the mid-rg9os, when the tobacco warehouses and allied businesses closed following the downturn of the tobacco industry resulting from successful lawsuits by several states. Together with Bill Kalkhof, executive director of Downtown Durham Inc., Wilcox and Eshelman garnered community support and, in I995, organized a public planning charrette to envision ways to revitalize the area. Eshelman provided the funds necessary to seek professional expertise key to the success of the community workshop, which included three design teams comprised of architects, planners, and citizens. The various design proposals had one common component: an urban park that would provide "a place for public art, picnics, concerts, and community gatherings-a catalyst for the neighborhood, and a venue that would serve the whole city." ${ }^{22}$ I particularly appreciate the "community gathering" part of the proposal's description as necessary for the success of the area's revitalization and as a symbiotic amenity for the farmers market.

During the period of public planning and the design directive outcome, the City of Durham initiated a bond referendum for civic infrastructure. Kalkhof was part of the group identifying the needs of the city and advocated for \$I.3 million towards the purchase of the few remaining businesses and decrepit properties in the Warehouse District, which today comprise Durham Central Park (see image 3.Io). It took 


\section{Open-Air Pavilion Markets}

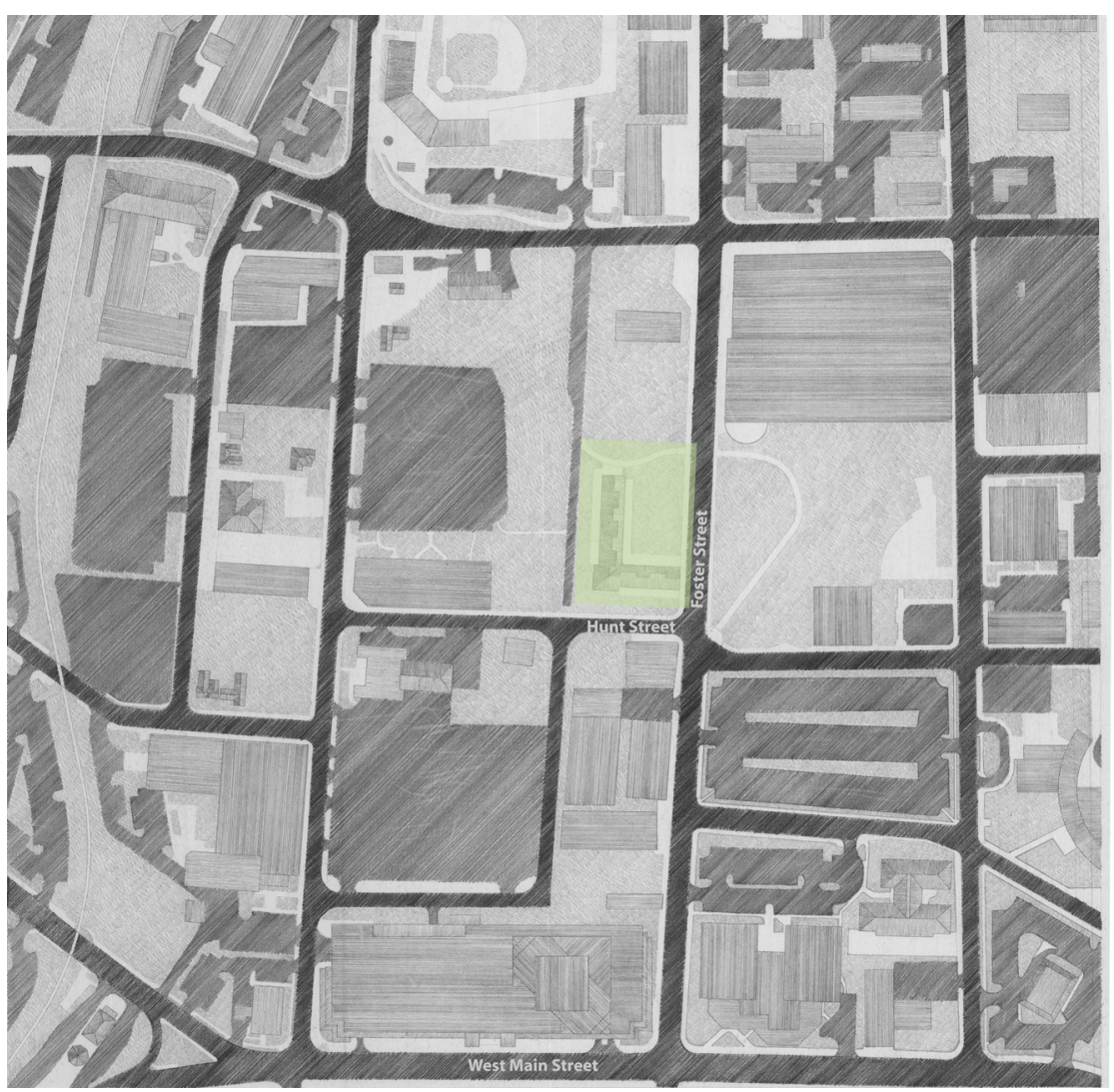

Image 3.10 Plan drawing showing the market pavilion at the heart of Durham Central Park.

twelve months of weekly meetings to purchase all twenty-seven parcels. Concurrently, Wilcox and Eshelman formed the nonprofit organization Durham Central Park Inc. to implement necessary operations and oversight, which includes developing the park, securing local businesses and nonprofit organizations to adopt sections of the park, and directing hundreds of volunteers who come out for workdays to maintain and improve the park. ${ }^{3}$

Since the completion of the pavilion in 2007 , it's been used for weddings, summer movies on the lawn, and free concerts throughout the year. Despite its multifunctional use, however, the structure's primary identity comes from the Durham Farmers Market, where vendors sell locally grown and produced foods from April through October on Wednesdays, and year-round on Saturdays. The farmers market arose 


\section{Chapter 3}

from a group of local citizens who advocated for fresh, healthy food, particularly food that is regionally sourced. Elizabeth Gibbs, one of the citizens involved in the market's formation, asked local food co-op owner Christine Westfall to assist her in finding farmers to constitute a seasonal market. Shortly thereafter, from June to September in I999, about a half-dozen farmers set up in the parking lot adjacent to the former Durham Bulls baseball field. While the market had committed vendors, Elizabeth saw the need for more formal organization-throughout the winter, she and a few others collaborated to write rules and regulations for the next season. They also continued to recruit farmers and other local food vendors, and Elizabeth served as market manager from 2000 through 2005. ${ }^{14}$ Another civic activist for fresh, local food access and a key supporter of the farmers market, Brenda Brodie, cofounded with Annice Kenan the nonprofit South Eastern Efforts Developing Sustainable Spaces (SEEDS) in r994. SEEDS has occupied a stall at the farmers market since 2000, where they promote their "vision of transforming neighborhoods and lives through gardening," a vision that has grown to include "community gardening plots, an outdoor classroom, a greenhouse, environmental education exhibits, and a display of ornamental and edible plants." ${ }^{15}$

Increasing access to fresh local food within the community has a long, bountiful history at the Durham Farmers Market and most recently expanded its impact through local nonprofit Farmer Foodshare, which collects 5,00o to 6,0oo pounds of donated food from the farmers market at its Donation Station each year, which is then distributed to those in need through Iglesia Emanuel food pantry not far from the market. And in April 2014 the farmers market began accepting SNAP and offered Double Bucks up to $\$$ Io for each visit beginning in July the same year. As of mid-May 2019, the program has disbursed $\$ 75$, ooo through the program since its beginning. ${ }^{16}$

A multitude of shoppers came to the market from the outset and the number of vendors steadily grew; however, after a few years, the baseball parking lot presented too many difficulties; in particular, intermittently locked gates on Saturday mornings. Fortunately, a nearby company, Measurement Inc., learned of the situation and offered its parking lot; the farmers market, at that time with forty vendors, moved. Around the same time, Durham Central Park was taking shape, specifi- 


\section{Open-Air Pavilion Markets}

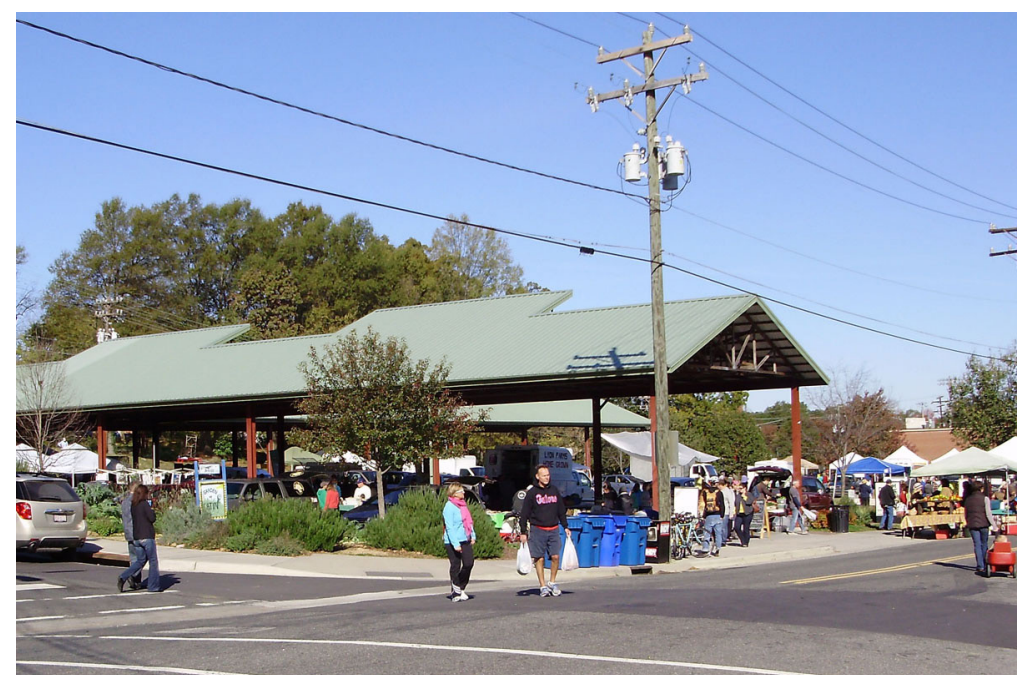

Image 3.11 View from corner of Foster and Hunt Streets.

cally the siting and design of a pavilion. From the beginning, Elizabeth Gibbs participated in Durham Central Park's meetings, in which she advocated for a permanent home for the farmers market under the new structure (see image 3.II). In the spring of 2007, the Durham Farmers Market moved to the pavilion, where it has gained presence and stature in the community in numerous ways, particularly through offering a better understanding of the culture of food and the necessity to change our food systems.

Architect Ellen Cassilly, a Durham Central Park board member and longtime patron of the farmers market, designed the pavilion at her office just a few blocks away from its proposed location. Ellen had been given the handful of designs that came out of the public planning process, which included representations from Durham Central Park, the Durham Farmers Market, and city staff. In collaboration with landscape architecture firm Coulter Jewell Thames, PA, she combined the multiple sketches into one cohesive design that accommodated the diverse wishes and needs of all involved.

I met Ellen during my first visit to the market in 2012. As we strolled under the structure, she pointed out various features of the pavilion, including the clerestory that allows sunlight through the peak of its roof. We settled on a bench in the Grace Garden adjacent to the structure. Curious, I asked why the pavilion was so tall. Ellen said that 


\section{Chapter 3}
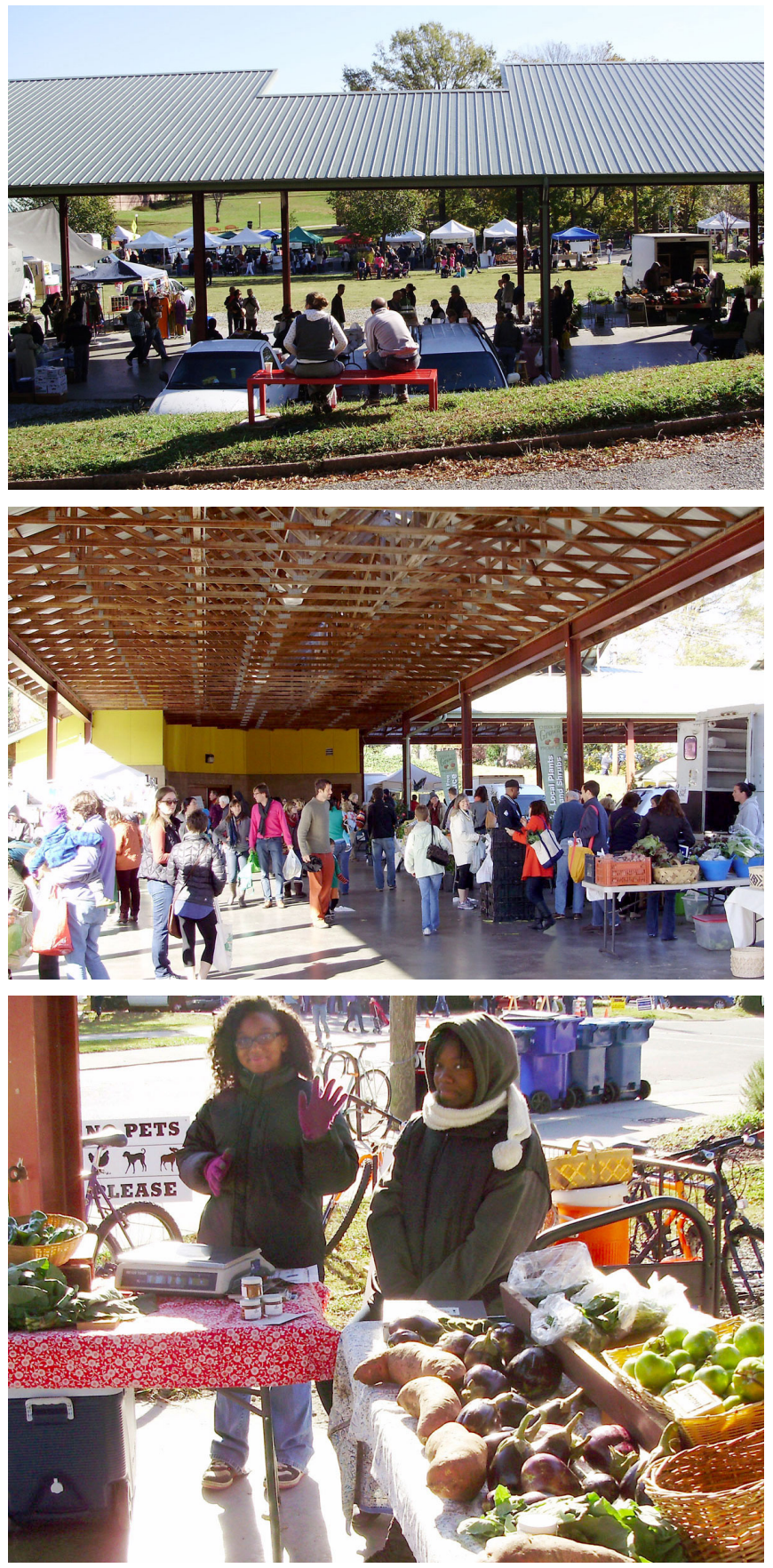

Image 3.12 top. View from Grace Garden.

Image 3.13 middle. Lots of activity under the pavilion at Durham Farmers Market. Image 3.14 bottom. Young enterprising vendors at SEEDS stall 


\section{Open-Air Pavilion Markets}

the farmers had requested room in the pavilion for a twelve-foot-tall van, but she did not want the structure to obstruct the view from above the park or from below to the three gardens located in the wooded area on the northwestern boundary of the park (see image 3.12). The pavilion sits on relatively flat land, but just behind it sits a short but steep hill rising about fifteen to twenty feet before leveling out for Grace Garden. From our vantage point, I understood her explanation for the pavilion's height; I could see the market activity under the structure, but also across Foster Street to the rest of the park.

That day, the farmers market buzzed with the activity of more than fifty producer-only vendors: thirty under the pavilion; a dozen pop-up canopies along one block of Foster Street; and another dozen along the northern edge, facing a grassy area with seating under a few trees. The market opened at eight in the morning, but around nine, flocks of families piled out of their minivans and SUVs in the parking lot at the southeast corner of Foster and Hunt streets and strolled towards the structure with empty tote bags draped over their shoulders or the back of strollers. At the entrance on Foster Street, the pavilion's red steel columns and green metal roof are striking. The proportions are grand in scale for a pavilion; it measures about twenty-five feet tall and forty feet wide (see image 3.I3). Once underneath the structure, slender wooden trusses spaced every two feet create the effect of a ceiling while allowing sunlight to shine through clerestory openings onto the concrete floor. The stalls are more spread out than in other markets I have visited; most have twelve to twenty-five feet of frontage. The center aisle, a spacious twenty-feet wide, allows a large number of people to shop without feeling too crowded.

Upon walking into the pavilion, I noticed two young girls standing behind an array of vegetables. Their unique display had two tables placed at almost ninety degrees to each other, creating a wide "V." Baskets of different shapes and sizes, full of sweet peppers, green tomatoes, and bags of spinach, covered the tables, with eggplants and yams spread out in front (see image 3.I4). One of the girls proudly offered, "We've grown everything that's for sale." I picked up a flyer lying next to the weighing scale, which explained that the girls were part of a community garden and educational program offered by SEEDS. In 2000 SEEDS had created DIG (Durham Intercity Gardeners), a youth-driven entre- 


\section{Chapter 3}

preneurial initiative in which teenagers grow produce, herbs, and flowers to sell at the Durham Farmers Market. ${ }^{17}$ After completion of the pavilion at Durham Central Park, in addition to having a stand at the market, SEEDS established a community garden, the "Garden of Eatin'," on the southwest side of the pavilion. SEEDS, in collaboration with volunteer organizations, designs, plants, and maintains their own section of the garden; however, the "Garden of Eatin"" is a "free-pick, public edible garden." 18 The accomplishments of SEEDS in conjunction with the farmers market validate my belief in the role of place and the ritual it supports in building community. This reminds me of Lucy Lippard's statement about place being "replete with human histories and memories. It is about connections, what surrounds it, what formed it, what happened there, what will happen there." ${ }^{9}$

I continued exploring the market displays, stopping at the bend in the L-shape configuration to admire a two-tiered display overflowing with bundles of pink, white, red, and purple radishes above dozens of heads of red and green lettuces. Behind the display, farmers Alice and Stuart White busily served customers eager to purchase the glistening goods grown on the Whites' farm, Bluebird Meadows (see image 3.I5). The Whites started selling a wide variety of vegetables, flowers, and small fruits at Durham's market when it existed only as a few pop-up canopies set up in a parking lot. In its previous form, Stuart observed, the market "was a wide-open space where you could go around...without touching anyone else." ${ }^{20}$ However, he added:

once they built the pavilion, the market turned into a circus-a huge cacophony bustling with people on Saturday mornings that for us as vendors is amazing. [The increase in customers] opened a lot of doors for us, as we could sell a lot more produce because people are really behind the market. ${ }^{21}$

Alice pointed out another benefit the market offers; she says, "Many of our customers have become our good friends. We've been to lots of social outings with our customers; there is no line between customer and friends sometimes." ${ }_{22}$ Stuart and Alice use organic and sustainable practices to cultivate "six separate fields, each with lots of character [and] slightly different soils and micro-climates" on their fifteen acres of rolling hills in Bushy Fork. ${ }^{23}$ 


\section{Open-Air Pavilion Markets}

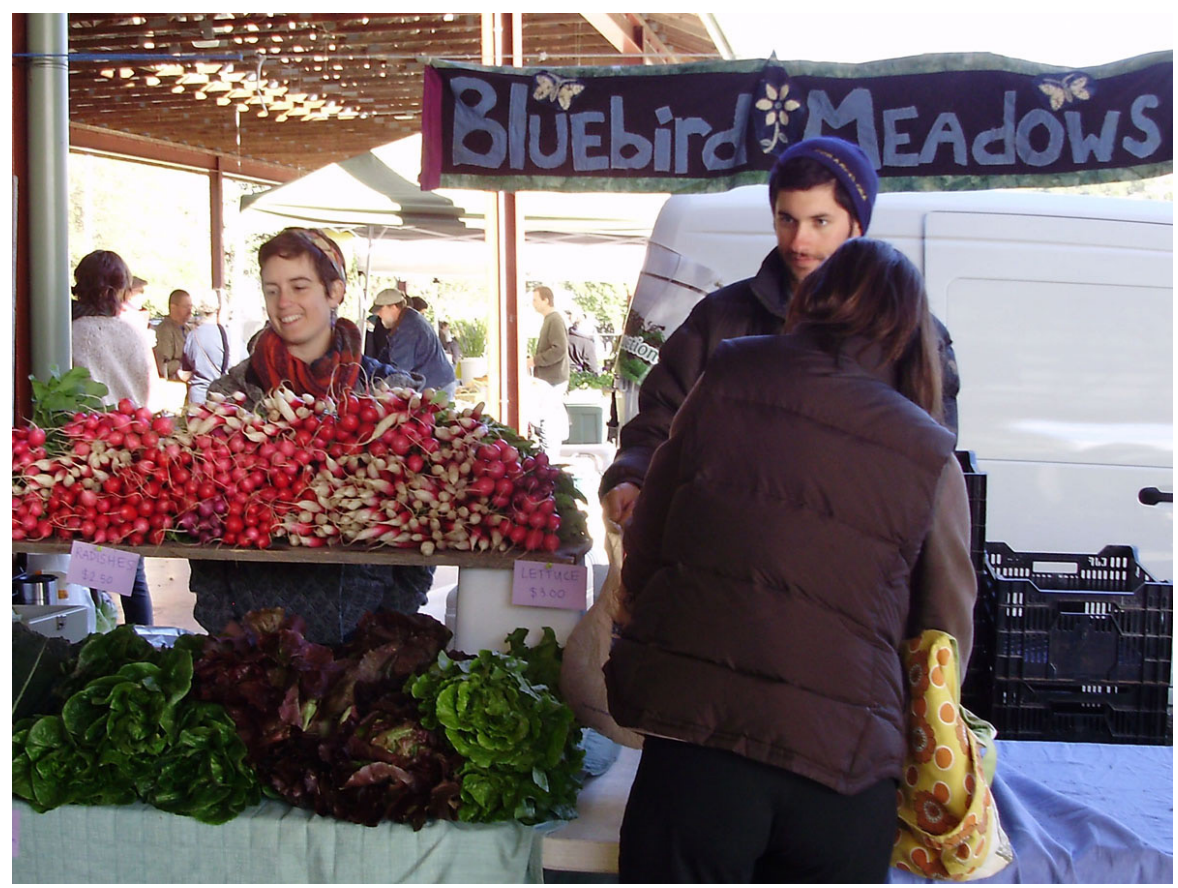

Image 3.15 Lots of radishes at Bluebird Meadows' stall.

Alice views the growth of the Durham Farmers Market and small farms in the surrounding area as having a significant beneficial impact on the community. She believes that, through farming and selling at the market, vendors are able to educate people "to be in touch with the community about food, the culture of food." ${ }^{24}$ She adds, "The next step in our local area is to be able to turn the vision-instead of just focusing on CSAs and farmers markets-[into] some kind of movement towards getting [local, fresh, healthy food] into the local schools and hospitals." ${ }_{25}$ It is clear from Alice's comments that Durham's farmers market has real potential to foster community beyond the city itself. Its influence could reach the wider Raleigh-Durham-Chapel Hill Triangle region and potentially create a network that crosses state boundaries and affects public entities like hospitals and schools.

Across from Bluebird Meadows' stall, I found the market information table, where I met the enthusiastic and energetic Erin Kauffman, in her sixth year as market manager at the time. Erin is employed by Durham Farmers' Market board, which has an agreement with Durham Central Park's board for its operation. Of her position, Erin said, "I like 


\section{Chapter 3}

my job because I meet interesting people, but it can be draining with all the different personalities." ${ }^{26}$ She explained that farmers typically have strong dispositions, which is why they succeed at farming and why Durham's market has grown steadily since moving to the pavilion. In its first year at its new location, the number of customers doubled, which led to much more community engagement and activity at the market. Erin told me that the farmers market's association with the pavilion and the market's increasing promotion of healthy eating prompted Durham Herald Sun editor Bob Ashley to invite her to write a weekly column about goings-on at the market. Erin believes that on non-market days, the presence of the structure alone reminds locals to visit the market on Wednesdays and Saturdays to shop for fresh, local food. Ellen Cassilly concurs about the influence a building can inspire simply with its physical presence, even in the absence of designated activity. She knows this effect from direct experience; her architecture office is located a block from the pavilion. Ellen says:

The area became scary when the tobacco warehouses closed and allied businesses left. Now, due to the revitalization that Durham Central Park and the pavilion have spawned, I can walk a block to get a cup of coffee from a shop that just opened its doors after getting its start at the farmers market. In another direction, I walk a block to grab lunch, or take a yoga class after work. ${ }^{27}$

Tim MacAller of Four Leaf Farm also credits the pavilion with substantial community impact in multiple ways (see image $3 \cdot 16$ ). He and his wife Helga, who have sold at Durham's Central Park market since 20oo, experienced the improvement first-hand. He says:

The structure has made the market seem like a real permanent feature in the city. It has brought people to a part of town that was mostly empty twelve years ago and has fostered many new businesses around the market area. The structure has made the market seem an "official" part of Durham and the growing local food movement. ${ }^{28}$

Tim and Helga enjoy selling at the market "because it gives them direct contact with others who share their love of food and gardening." ${ }^{29}$ In conversation with Tim about other benefits of the farmers market, he said: 


\section{Open-Air Pavilion Markets}

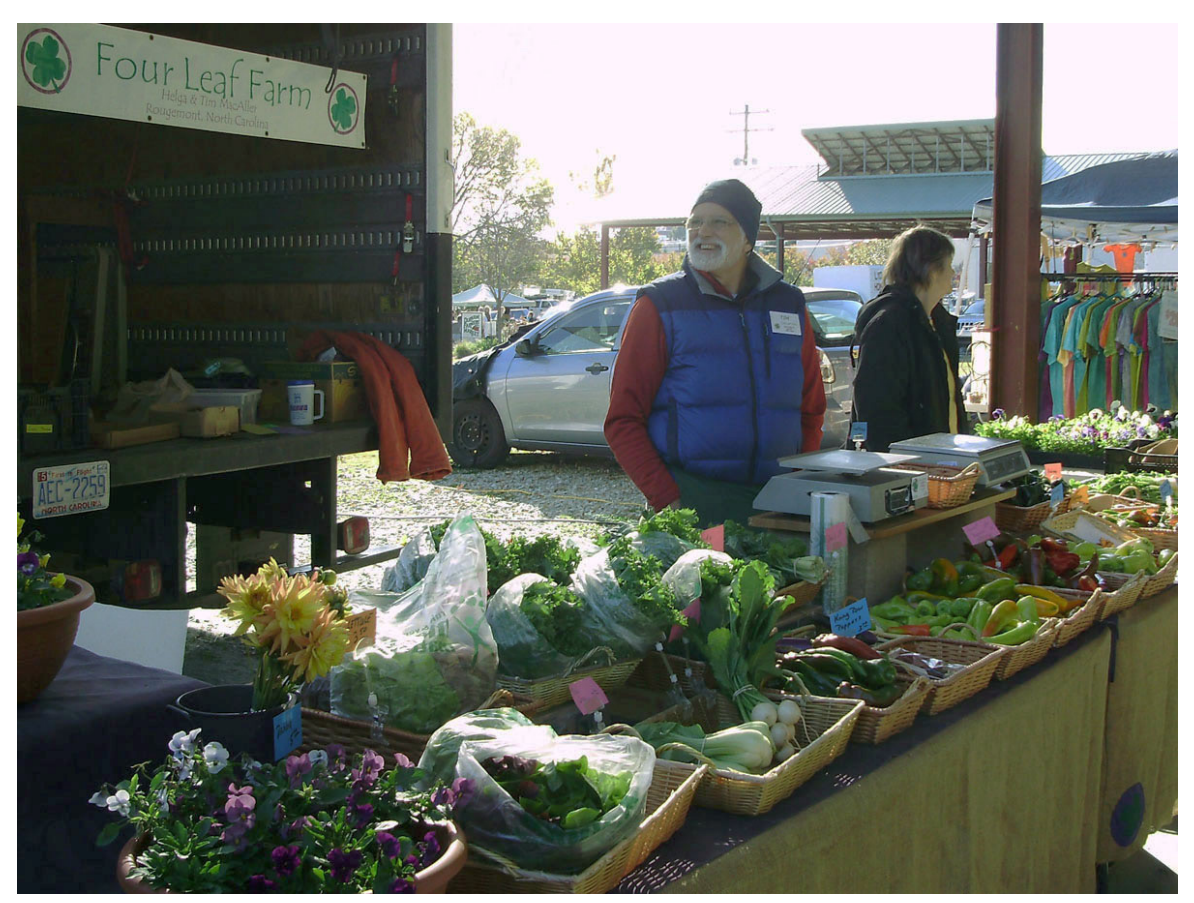

Image 3.16 Lots of variety at Four Leaf Farm's stall.

the interactions of the farmers and the customers also makes it feel like so much more than just buying and selling goods. It is always amazing for me to look out on a busy Saturday and see the activity around the market. People are meeting each other, kids are playing, and there is a sense of a community gathering, not just commerce. $3^{\circ}$

On my first visit to Four Leaf Farm's stall, the grouping of flowers and vegetables reminded me of props for a still-life painting. A few cantaloupes, a lone dark green acorn squash, and a basket of striped delicata squash surrounded a half-dozen deep yellow sunflowers in a French garden vase. On my next visit, the vase held peach-colored dahlias, the baskets were full of curly lettuces and multiple colors of sweet peppers, and a flat of purple and white pansies took the place of the squash. These memorable displays express the varied efforts of Helga and Tim MacAller, who cultivate one acre for "sustainable crops by following organic practices that produce healthy food full of flavor and nutrients." ${ }^{\mathrm{I}}$ Their farm also has an ornamental garden, a unique place with a diversity of flowers and foliage that especially thrive in North Carolina's Piedmont region. 


\section{Chapter 3}

Talking with Tim, I am reminded of the crucial role the vendors play in building community. When asked why he served on the farmers market's board of directors, Tim explained:

Helga and I served on the board because we believe in the entity of the market and wanted to see it grow and prosper in a way that supports all of the participants. If you want something to function for you and for others, then you should be involved in its governance. I think that all members should serve a term on the board. ${ }^{32}$

Thanks to Tim and other vendors and community members like him, the Durham Farmers Market was born out of community action, and by continuous and expanded citizen engagement has become stronger in its substantial positive impact on the livelihood and prosperity of residents and farmers alike.

In recognition of the contribution the pavilion has made to the community, architect Ellen Cassilly was given the 2007 Golden Leaf Award for Community Appearance from the Durham City-County Appearance Commission. The pavilion was also ranked \#I3 out of ror in the 2015 nationwide poll, "Iог Best Farmers Markets in America" by The Daily Meal, and remains in the top ror today. 33

\section{Covington}

When I first drove into Covington along Main Street from I-64, the scale of the buildings and development appeared similar to many charming small railroad towns located along the railroads that wind their way through the mountains of western Virginia. Two- and threestory late-nineteenth-century brick buildings with shops and businesses flanked a tree-lined, pedestrian-friendly street. Covington sits about $6 \mathrm{o}$ miles north of Roanoke in rural Alleghany County. It is officially a city, although according to the last census, in 20I0, the population was just under 6 ,ooo people. When I arrived at the new farmers market pavilion in the center of town, I was struck by the sight of the enormous Mead Westvaco facility in the background at the northwestern edge of downtown, just across the Jackson River. The stark contrast between these two structures speaks to the industrial and agrarian roots of Covington, while simultaneously suggesting at least some measure of coexistence in the new century (see image 3.17). 


\section{Open-Air Pavilion Markets}

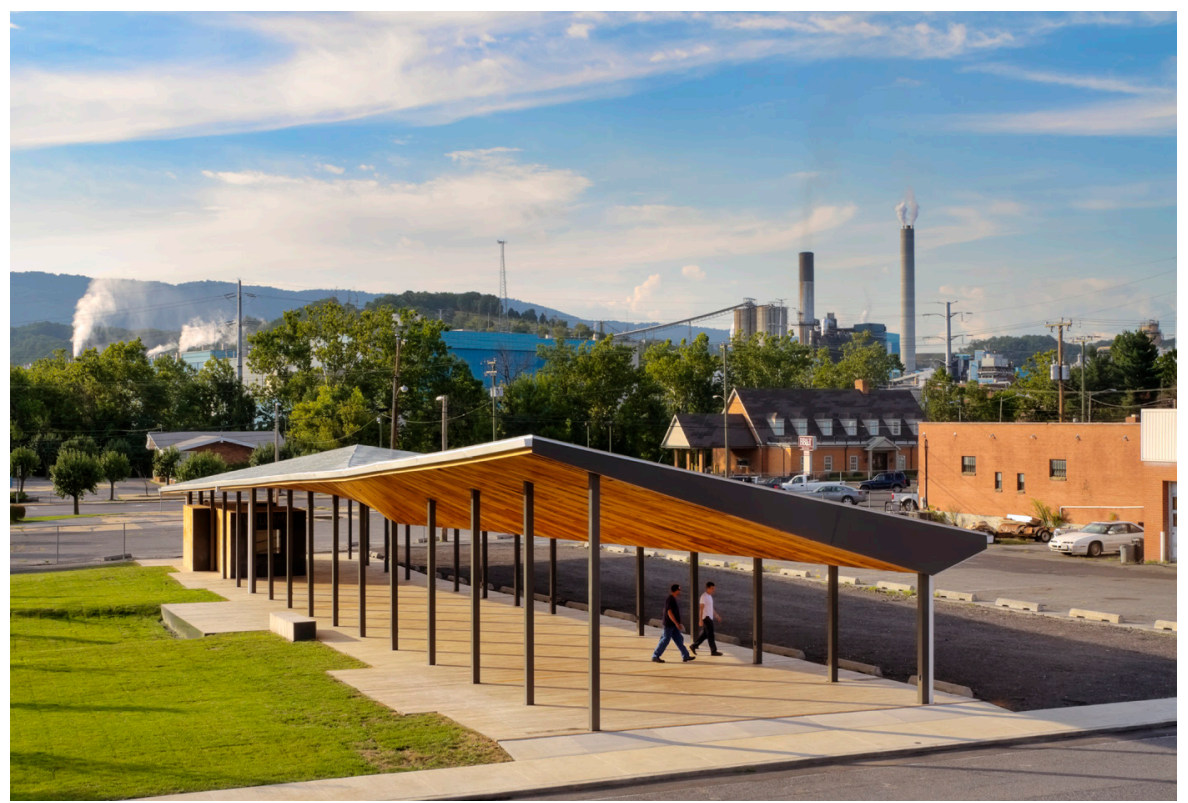

Image 3.17 Covington's new open-air pavilion juxtaposed with Mead-Westvaco's industrial facilities.

Completed in 20II, the open-air pavilion and adjacent linear park came about thanks to the vision and leadership of Jacob Wright, a seventh-generation Covington resident, along with Keith and Marie Zawistowski, then Virginia Tech architecture professors. The definitively modern and minimalist pavilion is the result of numerous hours of research, design development, and hands-on labor by seventeen thirdyear Virginia Tech students studying architecture while participating in the Zawistowskis' design/buildLAB. According to Keith and Marie:

This market pavilion is the expression of timeless agrarian sensibilities. Historically, farmers have been good at using available local materials and means with an elegance of economy. In this project we used locally available resources and the students derived the form of the pavilion in a way not so far from how a farmer builds a barn with concern for functionality and efficiency. For example, the roof and ceiling form of the market pavilion was designed to push hot air out from below while also collecting and draining rainwater. The uplifted corner along Main Street defines the entrance to the pavilion. ${ }^{34}$ 


\section{Chapter 3}

Fortunately, many kindred spirits in town have joined Jacob, Keith, Marie, and the students in this endeavor. The proactive and philanthropic Alleghany Foundation was pivotal to the realization of the pavilion; in 20I0, it awarded a \$II9,0oo grant towards the construction costs. ${ }^{35}$ Another key supporter was the Alleghany Highlands Chamber of Commerce and Tourism, which "strives to enhance the extraordinary quality of life for its residents and the exceptional range of opportunities for visitors by fostering a healthy business environment and promoting economic growth. ${ }^{36}$ Executive Director Teresa Hammond observes, "more people visit the market since the structure was completed in 20 II. More are aware of the benefits of eating healthy and the importance of supporting local farmers." 37 The Alleghany Highlands Chamber has a relatively new initiative called "Don't Roam, Shop Home," which aims to support all local businesses in towns within the chamber's boundary. Another new initiative, more directly aimed to establish the Covington Farmers Market pavilion as a community gathering place, is a series of chamber-sponsored events called "Rock the Block"; on one Friday evening each month in the summer and fall, local musicians play under

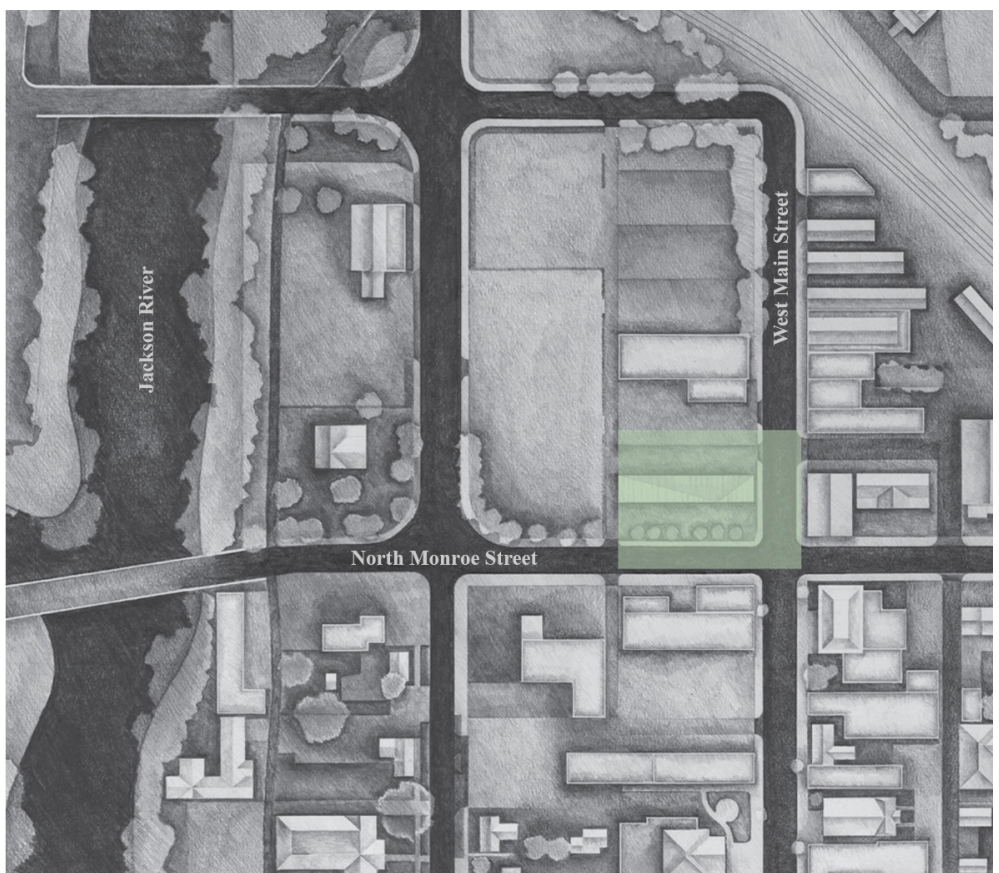

Image 3.18 Plan drawing shows farmers market pavilion's significant location in the heart of town. 


\section{Open-Air Pavilion Markets}

the pavilion while onlookers enjoy from the adjacent grassy park. Hammond also leads efforts to attain grants advocating for the portion of Route 6o known as the Midland Trail to obtain "Scenic Byway" status in the Alleghany Highlands region (see image 3.I8). The trail crosses Main Street at the intersection where the farmers market is located. The broad-based community strongly supported Covington's new market pavilion from the beginning of Jacob's vision to its completion, and community involvement remains steadfast today through these likeminded affiliations.

Jacob's involvement with the farmers market began following his father's death, when he moved to the family farm and dreamt of self-sufficiently growing his own food while also selling at a local farmers market. At the time, he didn't think Covington had a visually appealing location that would allow for a successful market. In 2009 Covington's farmers market existed as a group of ad hoc vendors setting up temporary pop-up canopies on Saturdays in a parking lot with limited visibility at the public library. This undesirable and likely economically unfeasible situation led Jacob and a friend to conceive a very simple structure for a more effective farmers market, which he proposed to City Council. They suggested the market move downtown to the highly visible corner of Main and Monroe Streets; City Council agreed and moved ahead to acquire the land, at the time owned by Mead Westvaco, who agreed to a land swap (see image 3.I9). Jacob's streak of good fortune continued; he then met Keith and Marie.

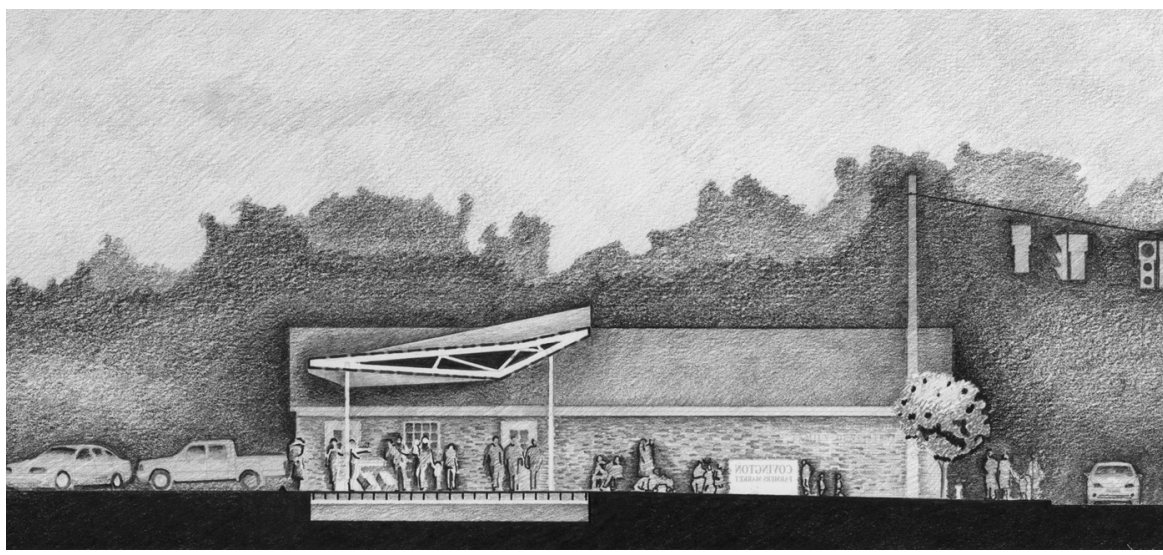

Image 3.19 Cross sectional drawing of pavilion shows relationship to street and adjacent buildings. 


\section{Chapter 3}

Jacob met the Zawistowskis while serving as a board member for the renovation of the Masonic Theater in nearby Clifton Forge. One day after a meeting he shared with Keith and Marie his vision and progress towards realization of a farmers market for Covington. To Jacob's surprise, they immediately proposed the prospect of working with Virginia Tech (VT) students who would design and build the structure. Of the chance meeting and collaboration, Jacob says:

It all happened so fast. Keith and Marie organized the students and garnered material donations from regional businesses. We all started applying for grants and soon received one from the USDA for marketing, a market manager for two years, and a mobile kitchen for cooking at the market; and another [grant] from the Alleghany Foundation for construction costs. It has been a whirlwind. $3^{8}$

Keith and Marie established design/buildLAB in 2008 based on their own experience designing and building projects in rural communities as participants of Auburn University's Rural Studio program. They met as students participating in the nationally acclaimed architectural design/build program, at the time directed by Samuel Mockbee. Keith and Marie conceived their new hands-on enterprise as

a project- based experiential learning program...focused on the research, development and implementation of innovative construction methods and architectural designs. Students collaborate with local communities and industry experts to conceive and realize built works of architecture that are both educational and charitable in nature. 39

This "charitable in nature" aspect of the Covington Farmers Market was not at all typical of most charitable arrangements. In many communities, new buildings come about as a result of collaborations between private companies and the local government. In this case, however, the students envisioned, designed, and presented everything. Their professionalism, enthusiasm, and charm won over the hearts of the community, such that when it came time for assembling the prefab components of the pavilion, residents housed and fed students in their homes for three weeks. One of the project's early supporters, Martha Nicholson, recalls welcoming the students as if they were her own children visiting for a few weeks. (Her daughter Jennifer had graduated from VT's 


\section{Open-Air Pavilion Markets}

School of Architecture + Design in 2005.) Martha now serves as part of the steering committee that oversees market operations. On many Saturdays she spends time at the market in the morning offering coffee to shoppers to encourage informal gathering and conversation. Facilitating face-to-face interaction is an essential part of the farmers market's mission statement: "To promote the sale of local products, to provide an educational forum for consumers and vendors, and to enhance the quality of life in the area by providing a community activity that fosters social gathering and networking." ${ }^{\circ}$

The Covington Farmers Market Steering Committee is a subcommittee of Olde Town Covington, a nonprofit corporation whose mission is to revitalize downtown, specifically Main Street. According to the market's website, the steering committee is comprised of a "volunteer group of citizens who support the Covington Farmers Market and the local community by providing educational programming to vendors and our community, applying for grant funding, and planning special events that further enhance the Covington Farmers Market and our area." ${ }^{41}$ Not surprisingly, Jacob, Teresa, and Martha served as charter members along with Nicki Wolfe of the market's steering committee. Today the committee includes Virginia Tech extension faculty Christine Hodges, Jacob and Martha. Their responsibilities include market operations and the oversight of a market manager. Martha explains that the committee hopes to keep the market's momentum going, noting that "since the structure was built, sales have increased, there is a different clientele, and there are new vendors." ${ }^{2}$

Baked goods vendor Patsy McKinney welcomes the new customers that the new (2OII) structure has brought to the market. She began selling at Covington's farmers market in 2008 when she retired at age 7I, and fondly recalls when her parents took eggs and butter to sell at the farmers market many years ago. While Patsy admits that her baking requires a lot of work, she says that she loves everything about the market and considers the vendors and shoppers as part of her family. Patsy's bountiful display of fresh baked goods perfectly conveys her positive sentiments-they look like the dessert table at a family's holiday gathering. Two tables covered with elegant cloths under an array of cakes, pies, and preserves hold an eye-catching feature cake of the day, which sits in the middle on a doily-covered stand. Patty clearly takes pride in her market stand; with a broad smile, she tells me that her best-selling 


\section{Chapter 3}
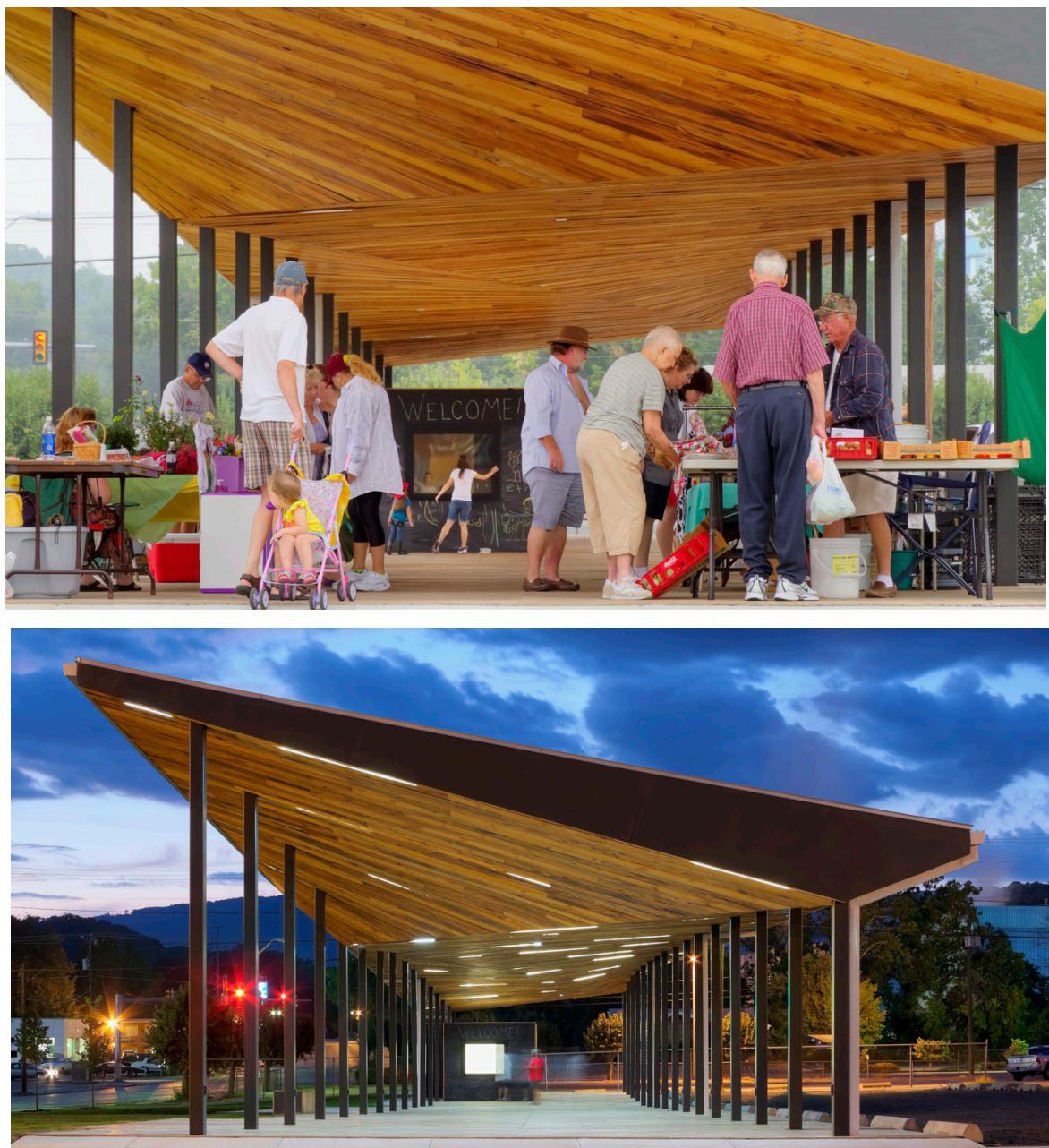

Image 3.20 top. Market day under the pavilion.

Image $\mathbf{3 . 2 1}$ middle. LED lighting integrated into the ceiling.

Image $\mathbf{3 . 2 2}$ bottom. One module of construction being hoisted into place atop steel columns.

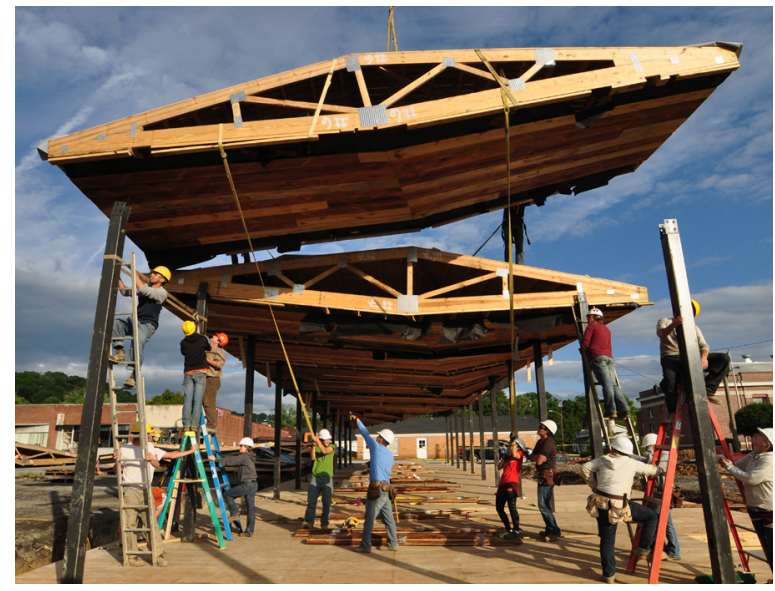




\section{Open-Air Pavilion Markets}

pies are pumpkin and custard, and that when berries are in season, she sells ten to twelve gallons of berries each market day. When asked about the new structure, she says, "It is mighty nice. Underneath it provides a good breeze on hot sunny days, and rain is no longer a problem. Having a bathroom is also welcome"43 (see image 3.20).

Set back thirty feet from Monroe Street, the pavilion provides the backdrop for a grassy, tree-lined linear park fronting the street. Both the park and pavilion extend half the length of the 320 -foot block from Main Street towards Riverside Street. According to Keith and Marie, "At the scale of the town, the pavilion reads as a seamless gesture, but at the scale of the person, the details express the modular construction." ${ }^{44}$ During one of my visits to the market, I noticed a particularly clever illustration of the pavilion's ten-foot (height) module: a four-inch-wide recessed black channel runs along the ceiling, contrasting the smooth wood and concealing simple linear LED strip light fixtures (see image 3.2I). To my delight, the streaks of light shine through the ceiling at nighttime and give the pavilion a presence that invites community gathering even after dark.

Keith and Marie's students conceptualized the project in three parts (which helped to organize the construction): (I) the pavilion roof and ceiling, including a rainwater-capturing feature; (2) the ground plane, including the pavilion floor and surrounding landscape; and (3) the occupied space, including the vendors' selling space, bathrooms, and the manager's office. ${ }^{45}$ The rainwater-capturing feature carries the water into a cistern below the floor and irrigates the park's grass and trees, as well as serving the bathroom's needs.

The geometrically shaped ceiling/roof has turned into an icon of the pavilion's identity, as this distinctive sculptural component appears to hover over the building. Fifteen modules, each ten by thirty feet, comprise the I5o-foot-long roof and ceiling (see image 3.22). Using a ${ }_{3} \mathrm{D}$ computer model, students calculated various angles for each of the diamond-shaped trusses to fabricate each one. The roof is sheathed in galvanized steel from a mill in nearby Follansbee, West Virginia, and the ceiling is heartwood pine that Keith, Marie, and the students reclaimed from a warehouse in Clifton Forge.

The black locust wood floor is comprised of thirty ten- by fifteen-foot modules, such that there is a negligible seam down the middle. 


\section{Chapter 3}

The manager's office and bathroom units are each ten-foot cubes. Students constructed all the modules in Blacksburg at a facility owned by Virginia Tech over the course of ten weeks. As they worked on the modules, Jen-Fab, a local steel shop that predominantly services Mead Westvaco's paper mill, fabricated the steel columns using drawings the students had made. During this time, the general contractor prepared the site by connecting the utilities and constructing the foundations of the pavilion. Once all of the modules were complete, they were transported to the site over a couple of days, and within a week placed into position using a crane and the students' muscle. The pavilion's construction represents another parallel to agrarian sensibilities, as the assembly method resembled traditional barn-raising. This congruent process that incorporates prefabrication has an advantage over conventional construction, which occurs sequentially and usually over a much longer period of time. The components and final pavilion were completed in sixteen weeks. This incredible feat depended on the interconnectedness and resolve of Covington's public, which again illustrates a farmers market's ability to enrich a community's way of life.

The model of education combined with design and construction, and the extraordinarily beautiful outcome, drew considerable local, regional, and national attention in publications, particularly online. The entire story was featured on Arch Daily and Architect magazine, and the state chapter of the American Institute of Architects gave it an Honor Award for Excellence in Architecture just a few months after it was completed in 20II. ${ }^{4}$

The three open-air pavilion markets featured in this chapter-in Abingdon and Covington, VA, and Durham, NC- serve a unique role in their communities as gathering places on market days and various other civic events on non-market days. In this sense, open-air pavilions have the capacity to assist in economic development in ways that are quite distinct from the other market types (heritage building and pop-up canopy) discussed in this book. Harrisonburg, Virginia's new downtown pavilion, completed in 2008, offers yet another example of the manifold benefits this building type offers communities as a home to a farmers market and other recurrent activities and festivities. Harrisonburg Market Manager Josie Showalter says: 


\section{Open-Air Pavilion Markets}

The existence of the pavilion is important to making the farmers market more present on non-market days. Its downtown location provides great visibility such that numerous community events occur on non-market days, such as Rockdown Beer Fest, and Wine and Dine. ${ }^{47}$

Josie says that one of the biggest surprises, and benefits, of the market in Harrisonburg is that she doesn't see as many people texting each other as she typically does in restaurants. People look each other in the face and have animated conversations. Market day is often the premier social event of the week, where people drink coffee, hang out, and talk before or after they've done their shopping. $4^{8}$

The benefits to civic life that an open-air pavilion farmers market can bring are summed up in a statement on the website for the farmers market in Hot Springs, Arkansas. It boasts that its Historic Downtown Farmers Market "has become a 'front porch' of sorts for many Hot Springs residents and visitors who gather, visit, sip coffee, and savor the live local music on Saturday mornings in addition to doing their weekly produce shopping." 49 The analogy of a farmers market to an architectural element of a building reinforces my premise of community gathering places that successful farmers markets become. The "front porch" is a place of interaction at the human scale. 



\section{CHAPTER \\ 4}

\section{POP-UP CANOPY MARKETS}

ARKeT SQuare IN Alexandria, Virginia, is home to one of the longest operating farmers markets in the United States. Residents have shopped there for fresh, local food since I753, when George Washington sent seasonal harvests from his nearby Mount Vernon farm to be sold. Early on Saturday mornings year-round, residents from the surrounding neighborhoods head to the market carrying flattened canvas bags and wheeling empty wire carts. From Royal, King, and Fairfax Streets, shoppers enter a brick-paved public plaza covered with numerous colorful pop-up canopies and umbrellas as they wind their way through a maze of tables that overflow with vegetables, fruits, flowers, and handmade goods (see image 4.I). When I first visited in 2007, I was struck by the huge square water fountain in the center of the plaza reflecting the colors and shapes of vendors' displays. I was also impressed by the way the brick steps, which link the large terraces, were integrated into vendors' displays and imparted uniqueness to the ubiquitous pop-up canopies and umbrellas. In contrast to these transitory collapsible assemblies, I noted that the permanence and materiality of the brick floor and surrounding brick buildings contributed to an enduring sense of place for this temporally circumscribed but long-ago established market. 


\section{Chapter 4}

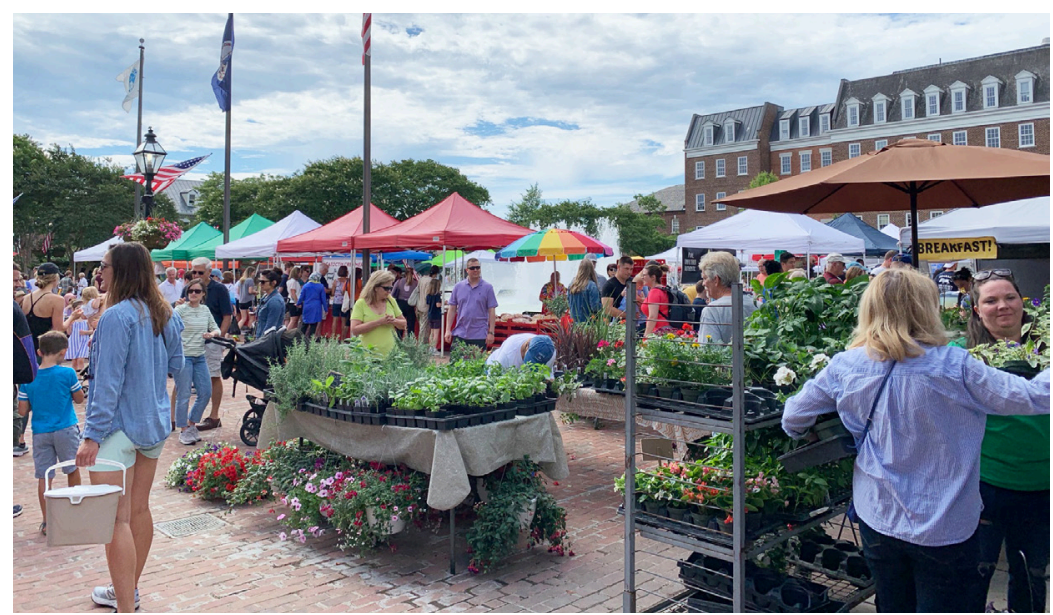

Image 4.1 Alexandria's Old Towne Farmers Market.

Alexandria's City Hall anchors the physical boundary along Market Square's entire northern edge. Three-, four-, and five-story buildings occupied by shops and restaurants at the ground level with offices and residences on the upper levels flank the south, east, and west sides of the square. Situated in Alexandria's Old Town neighborhood, this civic plaza sits just three blocks from historic docks on the Potomac River (see image 4.2). The city prides itself on the continuous operation of the market in the same location for over 265 years; markets of this type often do not sustain enough momentum to survive season-to-season, let alone for almost three centuries.

What makes markets like Alexandria's unique is their portability and adaptability to the particulars of any situation. I call these "pop-up canopy markets." In many urban locations, the same vendors habitually move from one location to another within a city on a daily and/or weekly basis. Pop-up canopy markets have a minimal physical presence and leave little trace of their existence on off days; often, only a small municipal sign with the market's hours denotes its footprint. In some instances, there are brightly colored banners with information on the farmers market attached to light posts or to the exterior of buildings adjacent to where they assemble. As is the case in Alexandria, pop-up canopy markets customarily rely on the stature of, and civic symbiosis with, surrounding buildings to provide identity, viability, and therefore, longevity for each market location. 


\section{Pop-Up Canopy Markets}

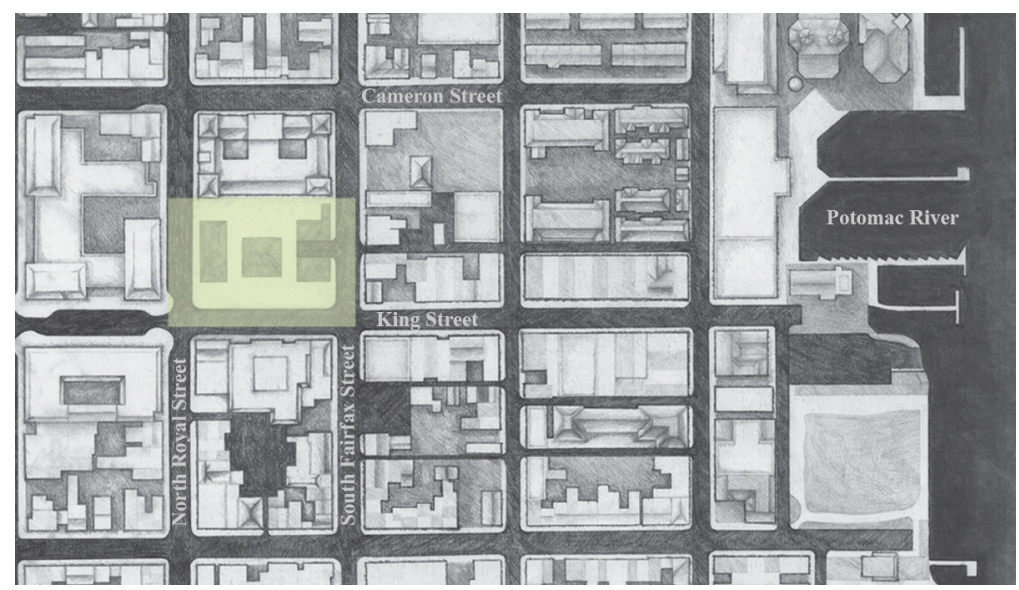

Image 4.2 Plan of blocks encompassing City Hall.

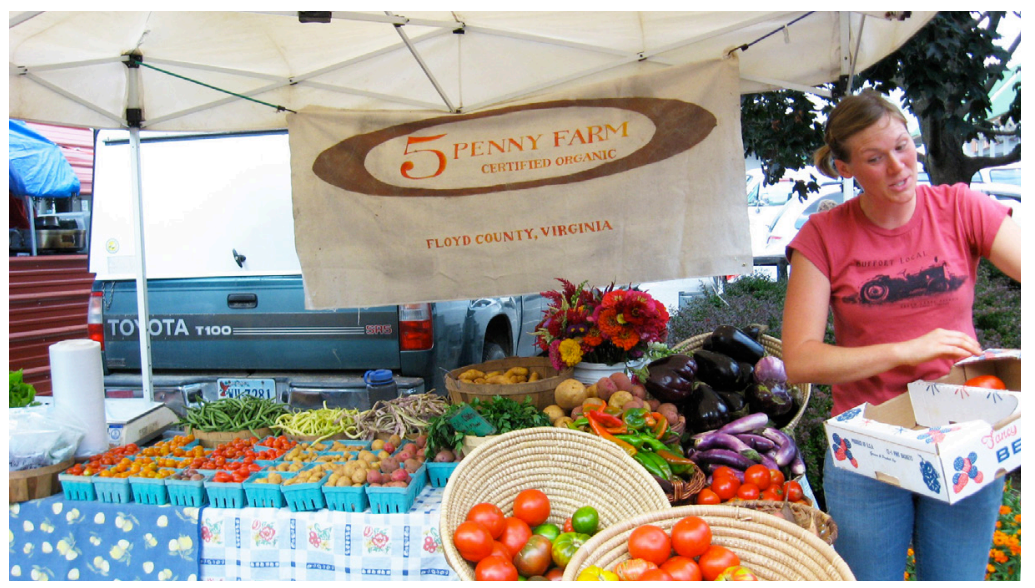

Image 4.3 Vendors express identity through unique displays and signage.

Most vendors use the fabric-covered, four-legged pop-up canopy structures because they shield their displays from the sun and rain while being easy to erect and collapse. Large canvas umbrellas are also stationed singly or in clusters for additional protection for goods and people from all kinds of weather. To display their produce and goods, vendors use lightweight, portable tables, shelving, and stackable bins similar to those typically used in open-air pavilion markets. Most vendors use only one pop-up canopy, although some configure three tables in a $U$ shape beneath two pop-up canopies. Banners and small signs disclosing the farm name and location hang most often from the rear of the pop-up canopy (see image $4 \cdot 3$ ). The unique composition of the ven- 


\section{Chapter 4}

dors' inventory provides a distinct identity for their stands in contrast to the sameness of their structural components.

The location of pop-up canopy markets is often dictated by the needs of shoppers. Typically they are positioned in places where people visit or pass through routinely via multiple modes of transportation including mass transit, car, bike, and walking. In most cities, they are situated in prominent plazas adjacent to landmark buildings, in parks or along a street. Other pop-up canopy markets are located in parking lots that are centrally positioned in a neighborhood or downtown and both can be publically and privately owned. In this manner, elementary and secondary schools, youth and senior centers, and YMCAs extend their role as community gathering places.

In Chicago, many of the same vendors assemble to form farmers markets in multiple locations throughout the city on varying days of the week: on Tuesdays, in the plaza in front of the Museum of Contemporary Art; on Thursdays, in Federal Plaza adjacent to the US Post Office; and on Saturdays, along two blocks of Division Street, a main thoroughfare in the Gold Coast neighborhood (see image 4.4 and 4.5 ). My husband and I shopped at the Saturday pop-up canopy market on Division Street for over ten years, but if I needed something during the week I could walk to one of the other locations (knowing which vendors would be selling what I needed on that particular day). At the south end of Lincoln Park, over fifty pop-up canopies comprise Green City Market on Saturdays from June through October. From November to May, during Chicago's blustery winters, it moves indoors to nearby Peggy Notebaert Nature Museum and boasts twenty-five vendors. Since its founding in r998, local chefs have come to consider Green City Market their "go-to" place for traditional produce such as green beans, red potatoes, and cherry tomatoes as well as rarer heirloom specialties (see image 4.6). Several of the market's farmers grow or raise food specifically for the city's premier restaurants. Paul Virant, chef at Vie, says, "Sourcing locally was one of the major missions of Vie when we started. I had some connections with a few farmers. I had worked with Paul Kahan at Blackbird, and there was a whole set of farmers he worked with... now over the course of the year, we work with forty farmers." Virant illustrates yet another example of farmers markets' capacity to create a sense of community even in large cities. 


\section{Pop-Up Canopy Markets}

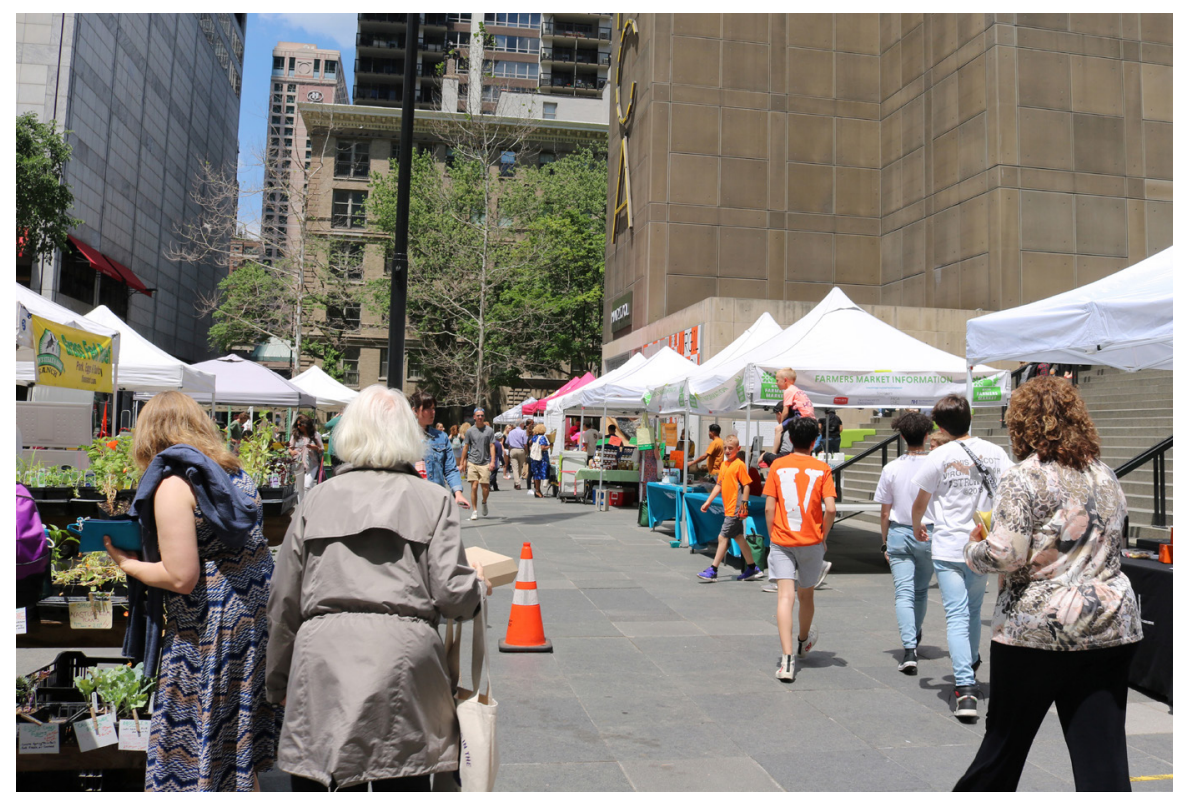

Image 4.4 SOAR Farmers Market sets up on Chicago's Museum of Contemporary Art entry plaza.

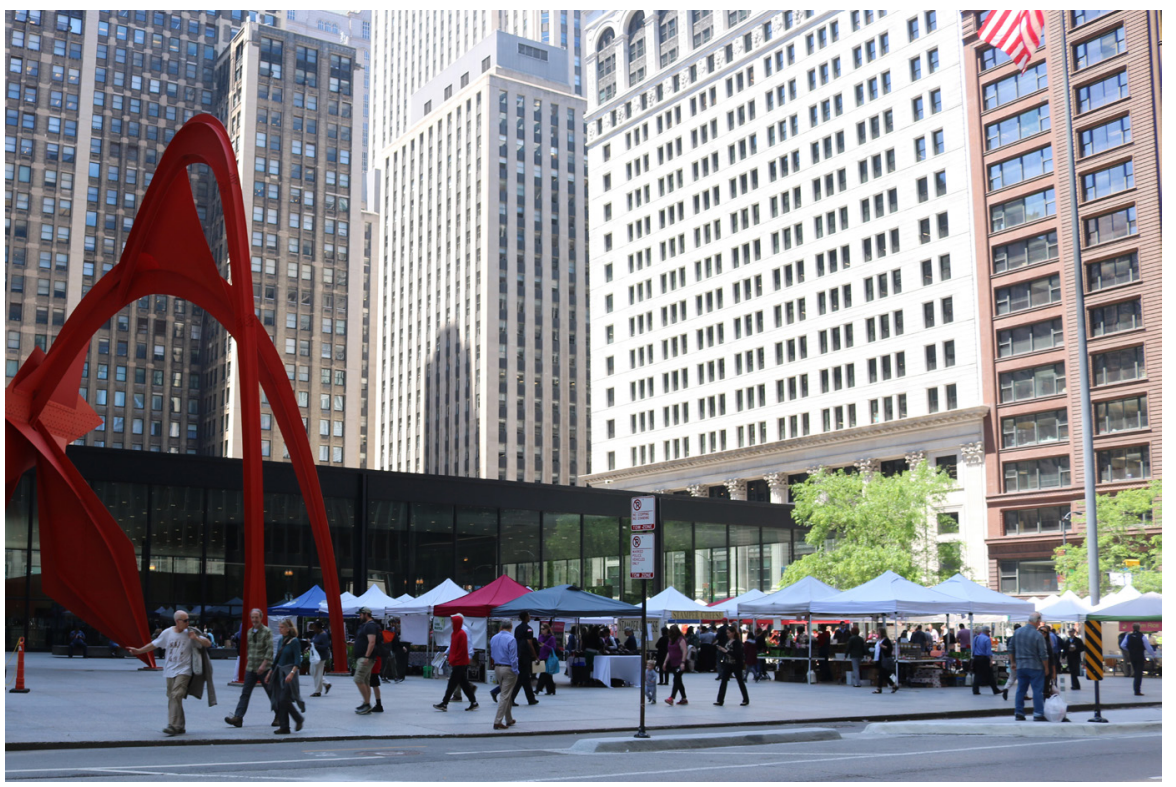

Image 4.5 Federal Plaza Farmers Market alongside sculpture by Calder. 
Chapter 4

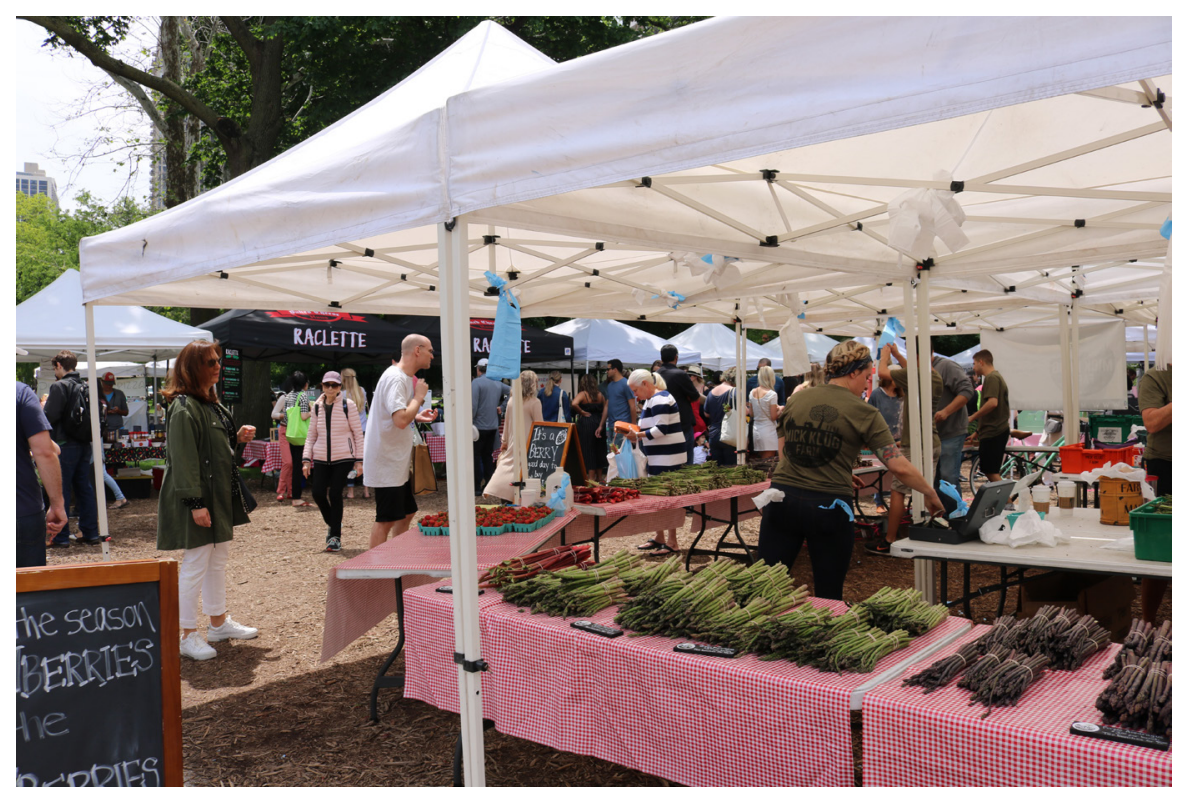

Image 4.6 Bundles of asparagus at Green City Market.

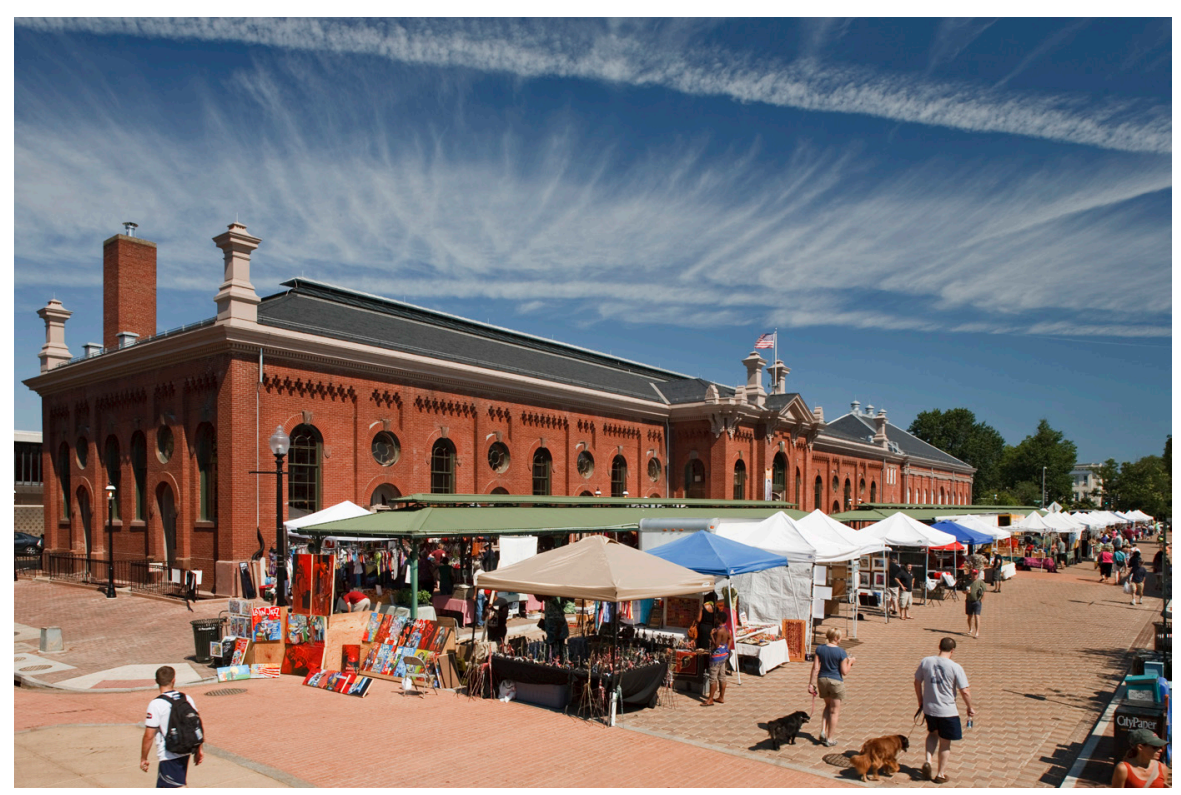

Image 4.7 Pop-up canopies line 7th Street at DC's Eastern Market. 


\section{Pop-Up Canopy Markets}

In Washington, DC, eight farmers markets of this type operate under the leadership of FRESHFARM, a nonprofit organization whose mission is to build and strengthen the local, sustainable food movement in the Chesapeake Bay watershed. Throughout the week in the Capitol region, temporary pop-up canopies appear at their appointed times in or nearby the city's renowned civic places. FRESHFARM has set up on Sundays in Dupont Circle, a landmark traffic roundabout and Metro stop, since 1997. During peak season, the market hosts more than forty vendors who offer foods and goods such as fruits and vegetables, meat, poultry, fish, cheeses, fruit pies, breads, fresh pasta, cut flowers, potted plants, soaps, and herbal products. In 2003 FRESHFARM opened its second location in Penn Quarter, followed by another one in 2004 in the heart of the once-again thriving historic district identified with H Street, NE. Similarly, in the famous neighborhood of Georgetown its farmers market has set up pop-up canopies at the entry plaza of the Foggy Bottom Metro stop on Wednesdays since 2005. FRESHFARM opened a new market adjacent to another prominent DC landmark, the White House, in 20og. Former First Lady Michelle Obama spoke at the opening of the Thursday pop-up canopy market, where she declared, "Markets are about more than food, they are also about creating better communities." In recent years FRESHFARM continues to expand its reach-opening pop-up canopy markets in 2013 in the Mt. Vernon Triangle and most recently at City Center in a new park between metro stops at Gallery Place and Metro Center. In all, FRESHFARM operates thirteen farmers markets in Virginia, Maryland, and DC that draw over 360,00 shoppers annually.

More and more frequently it seems, pop-up canopies are becoming regular fixtures at established heritage markets and open-air pavilion markets as vendor spaces within these structures become filled to capacity. Often, these additional vendors are small, local growers who offer more in the way of seasonal foods and goods. At Washington, DC's Eastern Market and at Cincinnati's Findlay Market, pop-up canopies form clusters along adjacent streets, transforming them into festival-like pedestrian promenades on market days (see image 4.7).

In this chapter I take an in-depth look at three pop-up canopy markets that all use public parking areas as their platform. On market days the parking garage and lots they occupy gain a civic function, turning 


\section{Chapter 4}

otherwise utilitarian public spaces into places of community gathering. All three markets are located in Virginia: Alexandria's is the oldest; Charlottesville's is unusually situated on a sloped parking lot in the center of town, and Staunton's is adjacent to the train tracks along the southern edge of its downtown. Despite the lack of permanent buildings, these pop-up canopy markets maintain their identity and thrive because they are places of community gathering as well as sustenance.

During the farmers market's absence on weekdays, Alexandria's Market Square serves as the entrance to City Hall. The square sits atop an underground parking garage, which would probably be empty on Saturdays if not for the market. On Saturdays, the assemblage of over a hundred pop-up canopies and umbrellas transforms the municipal plaza into a social and economic hub of residents and tourists sharing the pleasures of fresh food and camaraderie.

In contrast to Market Square's terraced brick-paved surface, Charlottesville's City Market sits atop a sloping asphalt parking lot, which necessitates that its vendors use numerous small blocks and devices to level their pop-up canopies and tables for display. Despite its resting place in a parking lot as opposed to a historic building, the market still has ties to the city's history-it's only a block away from East Main Street's pedestrian mall in historic downtown. Locals who consider the famers market a treasured institution have recently won a decade-old battle opposing those who wish to move the market to another location in order to develop the current location for significant economic gain. City Council approved a design and development proposal for Market Place in late 2015, but construction has yet to begin.

Like Alexandria's market, Staunton's also has historical significance; the government used the market house throughout the late eighteen hundreds for Virginia's Democratic and Republican conventions. Unfortunately, the building no longer exists; the farmers market's sheer presence in the historic Wharf District, however, has significantly driven the downtown area's revitalization since its origins in 1993 .

This chapter presents pop-up canopy markets through examination of their architectural and urban design features at the eight scales of interaction and interface outlined in the book's introduction. The most distinctive type of interface for this market occurs at the scale of gathering a half-dozen pop-up canopies in an area of fifty to seventy-five feet; this type of market gains success as its number of vendors increases. 


\section{Pop-Up Canopy Markets}

Pop-up canopy markets also gain identity through the stature of the market's location-its situation within neighborhoods, mixed-use districts, or downtown. The temporary nature of their existence only adds to their stimulating atmosphere.

\section{Alexandria}

Old Towne Farmers Market in Alexandria has had several configurations over its two and a half centuries of existence in the heart of Alexandria. Farmers originally sold out of their wagons parked adjacent to the town hall and courthouse. In 1817 , the town built a new three-story brick building along Royal Street with market stalls situated on the first floor of the west and north wings, facing a courtyard. An extensive fire in ${ }^{8} 8 \mathrm{I}$ necessitated significant rebuilding that inspired civic leaders and decision-makers to reimagine the multi-purpose structure; throughout the years, the building housed courtrooms and clerks' offices and served as the police headquarters, the principal fire company station, and the headquarters for the Alexandria Washington Masonic Lodge. Within a week of the fire, the city administration hired distinguished architect Adolf Cluss, who had just completed Washington, DC's Central Market in 1870 , to draw up plans for the new building. Cluss "was especially noted for his technical skill and attention to building safety and strength...His design reflected his strong emphasis on safety and the new building would be constructed from brick with cast iron columns, and rolled iron beams and trusses with roofs made of metal or slate."3 Fronting onto Cameron Street, Cluss's new U-shaped City Hall building encompassed a courtyard opening to the south, which was filled in by subsequent additions until the mid-twentieth century.

In the late ig6os, the Gadsby Commercial Urban Renewal Project brought about the reorientation of City Hall towards its southern façade, with a new primary entrance facing King Street and the addition of an underground parking garage beneath Market Square. ${ }^{4}$ The new entrance had a central double door flanked on each side with three broad arched recesses designated for use as vendor stalls on market days. While the renovations to City Hall accommodated the farmers market at the time, today Alexandria's premier farmers market is much larger, and by necessity it takes a different shape. The primarily pop-up canopy market sits three to six feet above encompassing streets and completely 


\section{Chapter 4}

covers the rooftop plaza of an underground parking garage completed in ${ }^{9} 67$ as part of the Gadsby project.

During a return visit in 2008, I parked midway along King Street across from the wide expanse (nearly one hundred feet long) of six steps bookended by three-foot-tall and four-foot-deep brick planters filled with small trees, shrubs, and flowers spilling over the edges. Thicker, lower brick walls containing large trees flank Royal and Fairfax Streets at the western and eastern edges of the plaza, providing a park-like atmosphere and safety from passing vehicles. On that warm, sunny day, numerous people sat on the brick walls under the shade of the trees and watched the bustling market activity surrounding the spurting fountain.

On market days, shoppers can find local American folk artist Patricia Palermino set up at the top of the center set of steps in front of the fountain. She told me that she selected this location because the water basin and southern elevation of City Hall provide a picturesque backdrop for her market display when approaching from King Street. Three tables draped with red-and-white-checkered cloths showcase blue and white wicker baskets full of notecards, children's books, and ornaments featuring her artwork. Next to the baskets sits a red metal bin full of blue aprons with her farmers market scene printed on the front. A white sign with blue lettering reads "Patricia Palermino Studio," the text surrounded by red stars (see image 4.8 ). The sign hangs prominently on a vertical screen holding framed artwork sheltered by two red umbrellas adjacent to the tables. 5

Palermino's works depict annual events in Alexandria and other popular US cities and landmarks; she skillfully captures the history, tradition, character, and charisma of a place. Part of esteemed American collections, her works hang in the White House, the National Archives, and the Winterthur Museum (and she also sells them in New York galleries). Although she captures many different locations in her art, she says, "Even though my art features other cities, landscapes and seacoasts, my works of Alexandria and DC are my best sellers at the farmers market"6 (see image 4.9). During our conversation, she reflected upon the joys of selling at the market and concluded, "the Old Town Farmers Market is a festive place, a community place where people come to chat and children come to play."7 In Palermino's work, I see a compelling connection between the visual narrative of symbolism and whimsy, and the vivacity and magical feel of the farmers market. 


\section{Pop-Up Canopy Markets}

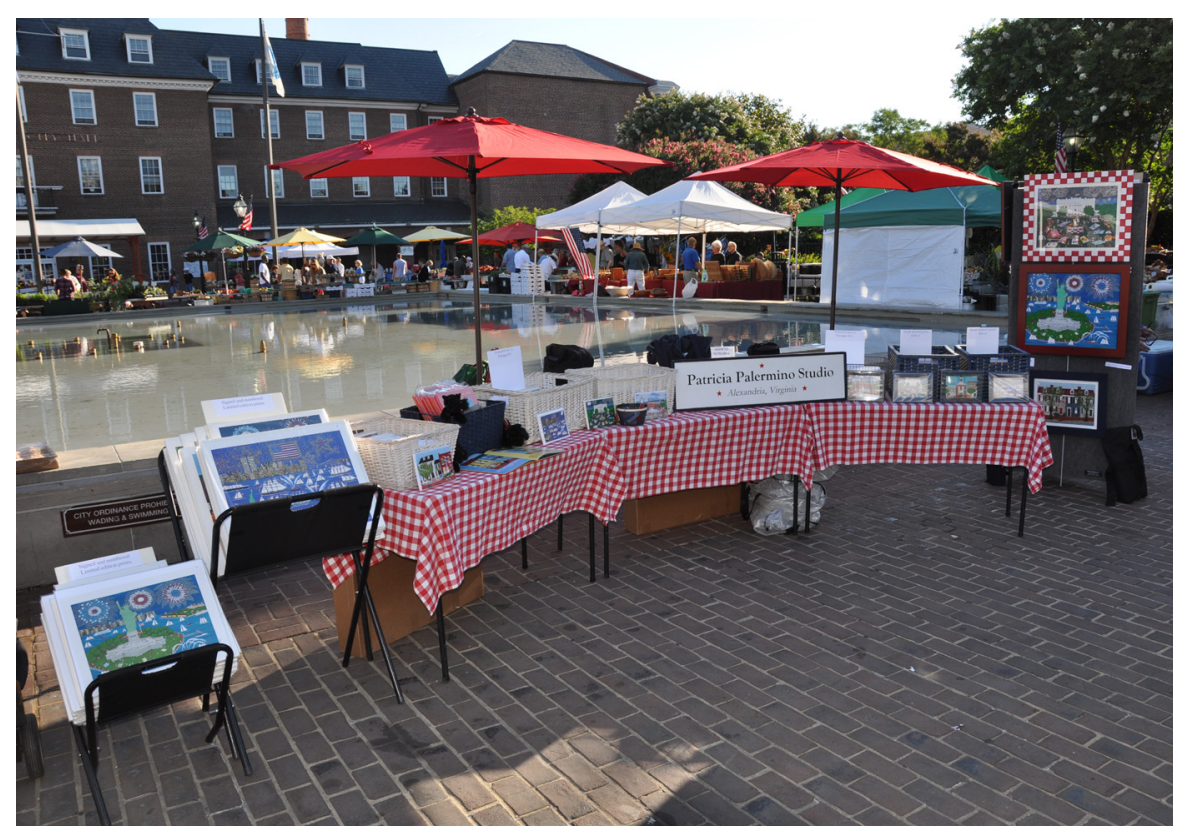

Image 4.8 Artist Patricia Palermino's stall.

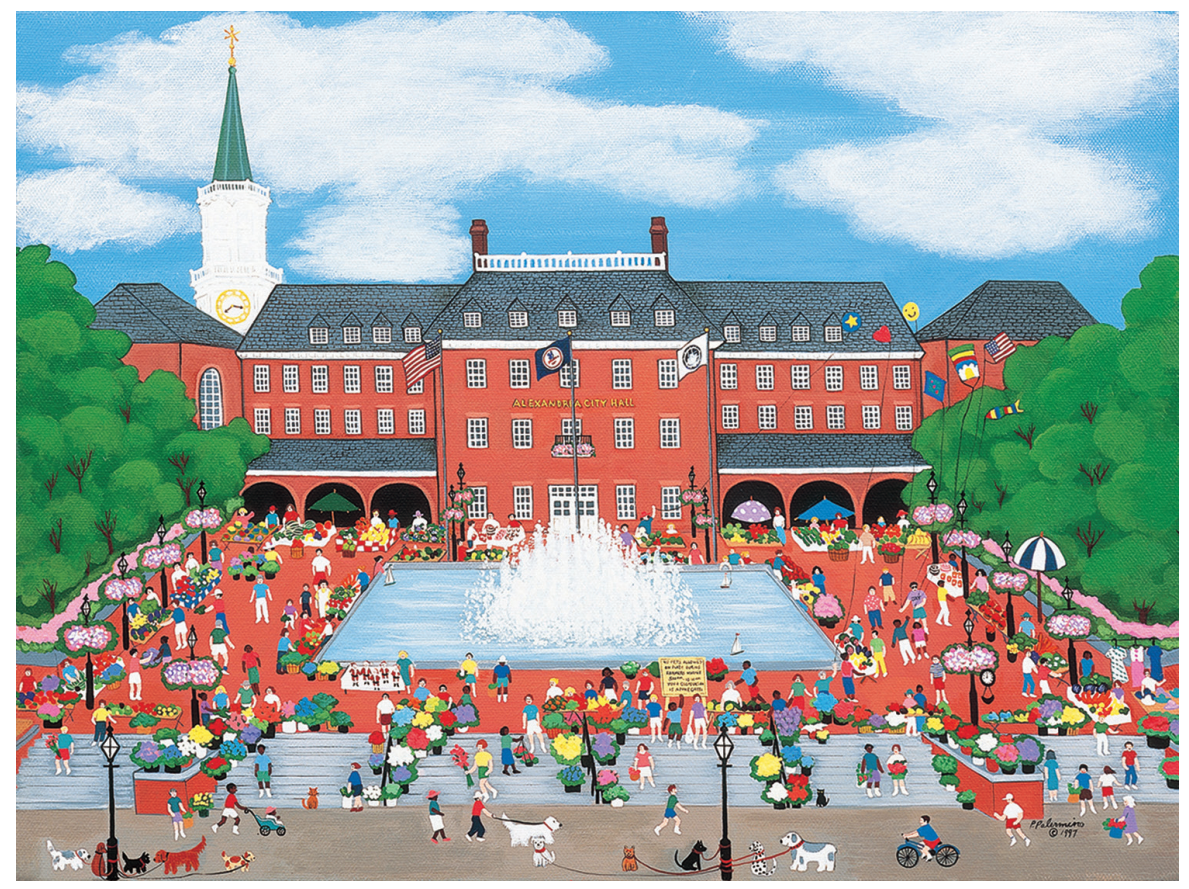

Image 4.9 Popular painting by Palermino. 


\section{Chapter 4}

Palermino is one of five framed-art vendors permitted to sell at the farmers market. Regulations established by the Alexandria City Council in 1989 also limit the number of handicraft (fifty-two), jewelry (seven), and wearable art vendors (seven); as well as the total number of vendor spots (гі6), but not the number of produce and food vendors. ${ }^{8}$ While "only thirty years ago the market had dwindled to a handful of farmers who sold produce to a faithful following of diehard customers," it thrives today and even has a waiting list of want-to-be vendors. ${ }^{9}$

As the number and variety of vendors grew, so did the number and diversity of shoppers. In 2012, conservative estimates stated that more than three thousand people passed through the market from seven in the morning to noon on a typical Saturday. By 20I5, the number of customers had more than doubled to nearly seven thousand during peak harvest months from July to October, and is approaching eight thousand today. Although limited-income residents make up only a small part of the increase in shoppers, the expansion of the customer base seeks to benefit these residents through intentional outreach programs. Alexandria's SNAP EBT coordinator Sara Rhoades holds frequent public forums to explain the availability and use of the USDA's SNAP Double Value Program at the Old Town Farmers Market. At the end of 2015 Rhoades provided me with figures regarding the success of her outreach efforts-from September 20I4 through September 2015, there were 260 shoppers who took advantage of using SNAP at the market; this was a 63 percent increase over the previous year. The SNAP dollars spent at the market from January through December 20I5 totaled $\$ 7,939$ - of which $\$ 3,634$ are monies funded by the Double Dollar Program, which matches SNAP EBT redeemed at the market up to $\$ 20$ per customer visit. ${ }^{\text {Io }}$ Today the program's fundraising goal is $\$ 5$, ooo to meet the needs of SNAP-eligible customers.

Rhoades also spearheaded other community outreach programs that supply fresh local food from the farmers market to people with limited income who cannot travel to the market. AARP (American Association of Retired Persons) featured on their blog her "Food Rescue" program that benefits a nearby senior housing complex as well as food pantries at two churches. The October 20, 20I5, article provides details about how Rhoades worked with vendors, gaining their agreement to work with the program, and then organized a group of volunteers to 


\section{Pop-Up Canopy Markets}

glean these vendors' stalls at the end of the market day, weigh their bounty, and transport it via bicycles toting small trailers five blocks north to the Annie B. Rose House, the elder residential center. Rhoades was very gratified with the results: that year the program supplied over 4, ooo pounds of fresh food at no cost to the recipients. In conversation with Sara, she mentioned that the market also facilitates innovative events and activities weekly on the small stage in Market Square aimed to attract and maintain a heterogeneous customer base. These included lots of local musicians as well as free yoga and bike clinics.

Over one hundred years after the establishment of the Alexandria farmers market, an ${ }_{1} 876$ edition of the Alexandria Gazette explained why the market stays the same decade after decade: because "to sell it here you've got to grow it or make it at home." " Well over another hundred years later, the Gazette's statement still rings true, as produce, meat, and goods sold at the market still come from nearby farms and regional producers. One strong proponent of authentic and fresh food, longtime meat vendor Tom Calhoun, has been selling at Alexandria's farmers market since the early ig8os; his daughter Tracy has joined him for the last thirty of those years. Tom has been curing hams for most of his life, learning from his father and grandfather on the family farm in Tennessee, and perfecting his old-time recipe on his own in Culpeper, Virginia, where he opened Calhoun's Ham House in 1964 . Calhoun's hams "are cured with a salt and brown sugar rub for eight weeks, then hung to cure for six to twelve months. This process dates back hundreds of years as a way to preserve meat without refrigeration." ${ }^{22}$ Calhoun's makes several ham products, including sausages and pork bellies often used for seasoning in vegetables and soups. Tom says one of their best sellers is the ham biscuit: they come in regular, medium, or tea-sized; they are sold individually, by the dozen, or in hundreds. ${ }^{3}$ He sources the biscuits from a local baker in Culpeper, then packages and sells them from the store and market (along with other synergetic homemade products such as honey and maple syrup).

Calhoun's Ham House market display, an elongated $U$ of four tables (two in the back and one on each side) sits under one of the open arches alongside the entrance to City Hall. The placement of products depends on who is in charge of the market stall; Tom likes to have the various items scattered about on the tables, while his daughter Tracy 


\section{Chapter 4}

prefers a more orderly arrangement, with items grouped and aligned with one another. Tom maintains that customers are more likely to buy if the products surround them. Calhoun's doesn't have flashy signs, but they hand out brochures that describe the care and quality of the products they make and sell. Tom's relationship to his customers at the farmers market goes beyond the sale; he says, "I was raised in Alexandria, Old Towne, [so the] people are special [to me]. They come to the market because their neighbors are there, and maybe they only see each other each week at the market. They like to talk about what they buy at there." "It It is Calhoun's good fortune that the Washington Post and the Nero York Times like to talk about his products as well-over the years, numerous write-ups have praised Calhoun products. Chef and proprietor Patrick O'Connell of The Inn at Little Washington calls Tom Calhoun a "ham artist," noting that his hams "are moister, less salty and low on preservatives." ${ }^{5}$ Perhaps the ultimate testament to Calhoun's high-quality products: The White House has served Calhoun's meat for decades.

Siblings Yi Wah and Caitlin Roberts operate one of the newer stands at Alexandria's farmers market: Number One Sons (see image 4.IO). They began making kimchi, sauerkraut, and pickled vegetables in a thousand-square-foot basement in May 2012. Yi Wah and Caitlin

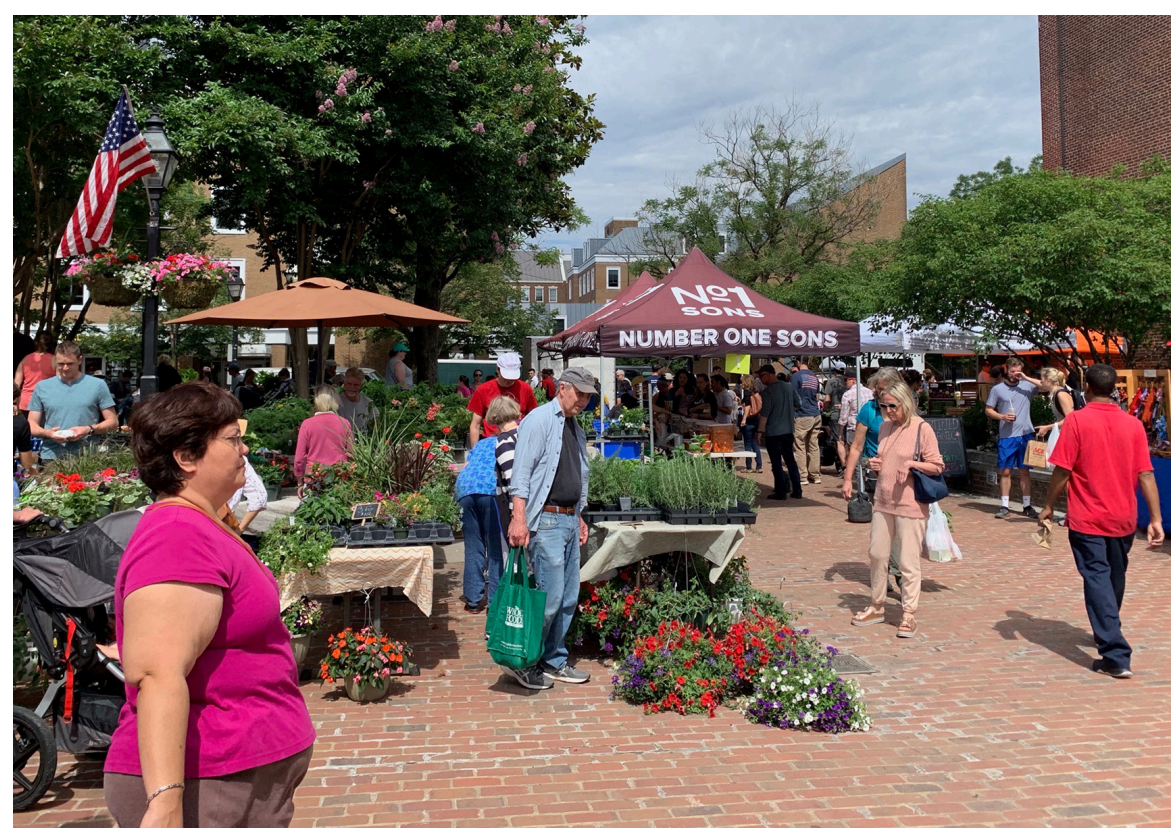

Image 4.10 Number One Sons stall at Alexandria's farmers market 


\section{Pop-Up Canopy Markets}

use a "mother brine" to pickle products instead of vinegar, more typically used in industrialized fermentation. With the "mother brine" pickling process, they take fresh seasonal vegetables sourced directly from local farmers and "introduce [them] to a bacteria-rich environment that slowly converts the latent sugars into acid and works naturally to cure the veggies as it imparts all its funky fermented flavors." ${ }^{16}$ Yi Wah and Caitlin strongly believe in the connection between how a product is made and its superiority-"slowness over speed and quality over quantity." ${ }^{\prime 7}$ They want their customers to know and understand the products they purchase and how they differ from conventional fermented vegetables, which include pickles.

At the farmers market, each item of their display has a label naming the food and identifying the ingredients, which range from the more familiar cucumbers, cabbage, peppers, and green beans to the less known okra, kohlrabi, beets, and radishes. Clipboards that describe their fermenting processes and the consequent nutritional benefits sit next to clear containers full of kimchis, krauts, and pickles alongside a variety of specialty items. The names are as eye-catching as the colors- Half Sours, Kicky Koshers, and Blond Mary Pickles; Stinkin' Rye Kraut, Clean Kraut, and Spring Ramp Kraut; Salsa So Verde, Dilly Beans, and Sauer-Rabi Kohlrabi. Caitlin likes to organize "the like with the like, usually lining them up from the least fermented and spiced to the most fermented and spicy." ${ }^{{ }_{1} 8}$ According to (then) Market Master Megha Even, Number One Sons had become a highly sought-after vendor in its very first year. In catching up with Caitlin half a dozen years later, she said Number One Sons sells at thirty-four farmers markets each Saturday within a thirty-minute drive from DC. All are pop-up canopy markets. When asked about the sense of community, Caitlin responded that the anchor vendors set the tone and everyone (young and old) shares their expertise. She added that the robust market scene in the DC area draws great customers. ${ }^{19}$

Megha Even began managing the Old Town Farmers Market in 20I3 after shopping at the market for ten years, and previously vending at a farmers market in New York City. In our conversation she exuded enthusiasm about her role, saying, "In my short time as market master, I have observed that the types of vendors are beginning to reflect the changing demographic of the city-more young families. And there 


\section{Chapter 4}

seems to be an equal mix of shoppers who walk to the market and others who arrive by car. Lots of tourists come to the market due to the historic nature of the place and to get a light bite. But I think the fact that it is a year-round market adds to the community feeling." ${ }^{16} \mathrm{I}$ echo Megha's sentiment that the market creates a sense of fellowship among strangers and friends as well as between veteran vendors and new ones. While many vendors at the market have sold there for decades, like Tom Calhoun, Megha says she's noticed these veterans welcome the newbies. In conversation with Tom Calhoun about his observations on how the market has changed, he said, "The Alexandria market has been very good for us as it grew. And, although people resist change at first, they get used to it. Particularly the changes in rules were necessary for the market to be good. They have helped improve the market. It is the only farmers market I will sell at." ${ }^{20}$

The city's Department of General Services (DGS) hires a Market Master to oversee the Old Towne Farmers Market. This individual, however, only coordinates with three newer markets established in partnership with Alexandria residents who recognized the growth and success of Old Towne and advocated for a market in their neighborhoods. The West End Farmers Market in southwest Alexandria opened in 2008, and in 20Io Del Rey Farmers Market in Warwick Village and Four Mile Run Farmers and Artisan Market in Arlandria set up their clusters of pop-up canopies. ${ }^{21}$ West End's farmers market assembles at the south end of Ben Brenman Park and showcases over forty vendors-those who sell the usual produce, meats, and cheese-but also vendors who offer unique products like locally roasted coffee and homemade dog treats. Del Ray's market operates year-round and boasts over twenty vendors; some of whom (similar to West End's market) offer unique treats like fresh donuts and croissants. The market at Four Mile Run opened in June 2010 with eight vendors who offer a wide variety of meats, cheeses, and produce, and the added bonus of tamales, salteñas, and empanadas. These markets have emerged from a strong sense of community and shared interest in eating local, healthy food, and have played significant roles in sustaining civic identity and neighborhood pride. Four Mile Run's market website describes how the market came about as part of a broad mission to revitalize the area in different ways, saying, "We're helping to fix a park, restore a stream and build community." ${ }^{22}$ 


\section{Pop-Up Canopy Markets}

\section{Charlottesville}

I first visited City Market in Charlottesville, Virginia, in late September 2011 on a windy but sunny day with a chill in the air. A dense mass of people cloaked in coats, scarves, and hats filled the aisle between parallel rows of pop-up canopies set up by vendors in a parking lot on a hill in downtown; the cool temperature clearly didn't deter people from shopping the market. I paused at the corner of First and Water Streets and observed a steady stream of people pushing strollers and pulling wire carts, when suddenly a man zoomed by on a motor scooter with a basket full of produce strapped to the rear. Not a second later another man glided by on his bicycle, carrying a bulging tote bag over his shoulder. All this lively activity gave me the familiar sense of exuberance and awe that comes with visiting any farmers market for the first time.

Intrigued to enter further into the market, I anxiously turned from left to right looking for Kirsten Sparenbourg, a former student of mine who knew of my longtime interest in farmers markets. Kirsten wanted to show me Charlottesville's premier market; she had just begun her graduate studies in historic preservation at the University of Virginia. I spotted her crossing Water Street, wearing a down vest, her head snuggled in a scarf. She enthusiastically led me up the cracked asphalt-paved

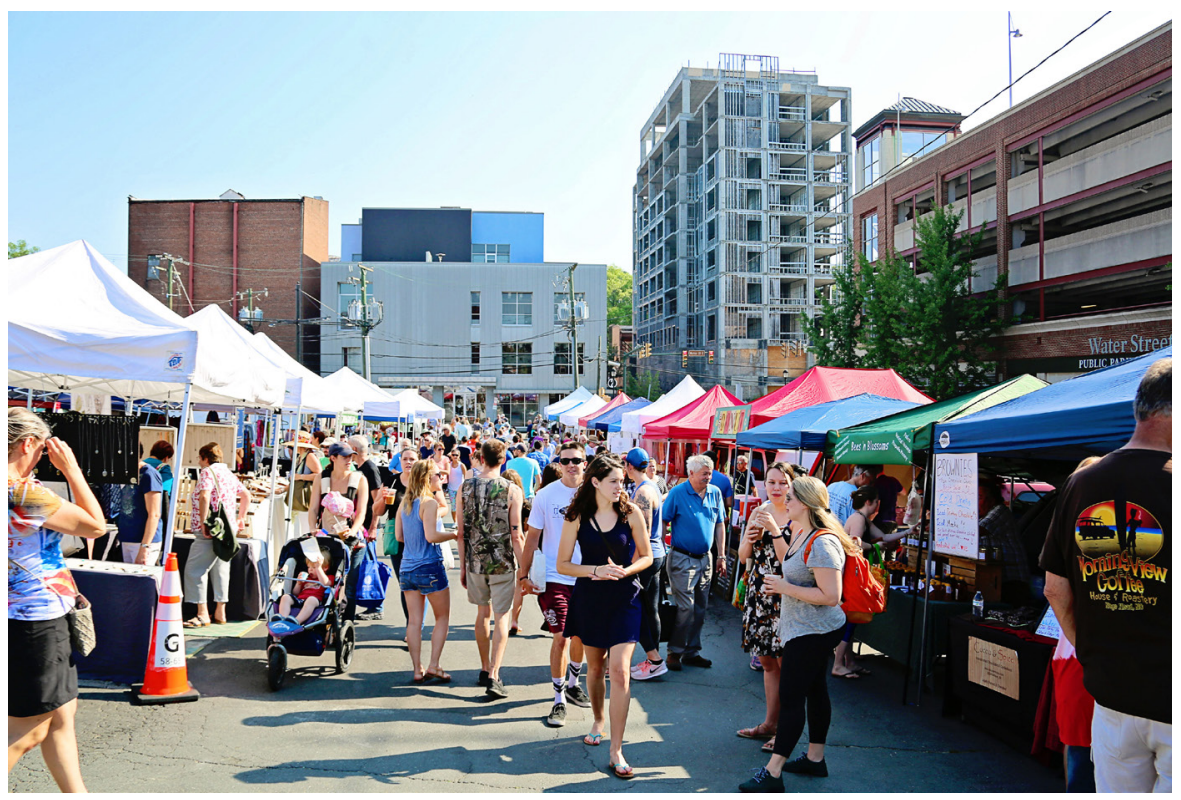

Image 4.11 Charlottesville City Market. 


\section{Chapter 4}

slope lined with brightly colored pop-up canopies sheltering tables covered by an abundance of produce, fruit, plants, and flowers. The stalls varied in depth; some used a single pop-up canopy, while others used two pop-up canopies to cover the entire ten- by twenty-two-foot parking space. At the crest of the hill near Second Street SW, Kirsten and I turned left into another aisle lined on each side with pop-up canopies, which extended on more level terrain over the rest of the block towards South Street. In total, the pop-up canopies accommodate roughly II5 vendors and almost completely cover the three-quarter-acre block measuring 32,670 square feet. By 20I4, an estimated four to six thousand people visit City Market each Saturday for nine months of the year ${ }^{23}$ (see image 4.II). The numbers continue to grow.

Charlottesville's City Market originated in 1973 on Vinegar Hill at the intersection of South and Ridge Streets. And despite switching locations a couple of times over the years, the market has grown and prospered because residents habitually shop there for fresh, local food, and value it as a public place for community gathering. ${ }^{24}$ In 1993, City Market moved to its present-day Water Street location on a city-owned parking lot situated in the heart of downtown only a block away from Main Street's pedestrian mall (see image 4.I2). The Historic Downtown Mall is anchored by the Virginia Discovery Museum and Omni Hotel at the southwestern end and City Hall (adjacent to the nTelos Pavilion) on Seventh Street at the southeastern end. Since its revitalization in I98I, the downtown mall has become part of the daily routine for many who work and live in this historic district as well as a must-see destination for visitors. The City Market benefits from a symbiotic relationship with Historic Downtown Mall, which is comprised of three- to five-story buildings representing eclectic architectural styles ranging from Greek Revival to Art Deco to sleek modern all-glass facades. The heterogeneity of the architecture is complimented by a diversity of retail shops and restaurants at the ground level with offices and apartments above. The vitality of this redeveloped eight-block-long area now extends down the cross streets, such that First and Second Streets connecting directly to City Market are bustling with people traversing back and forth. The growing economic success of this district has put even greater pressure on the two remaining undeveloped parcels, one of which hosts the farmers market. However, despite the market's positive economic and 


\section{Pop-Up Canopy Markets}

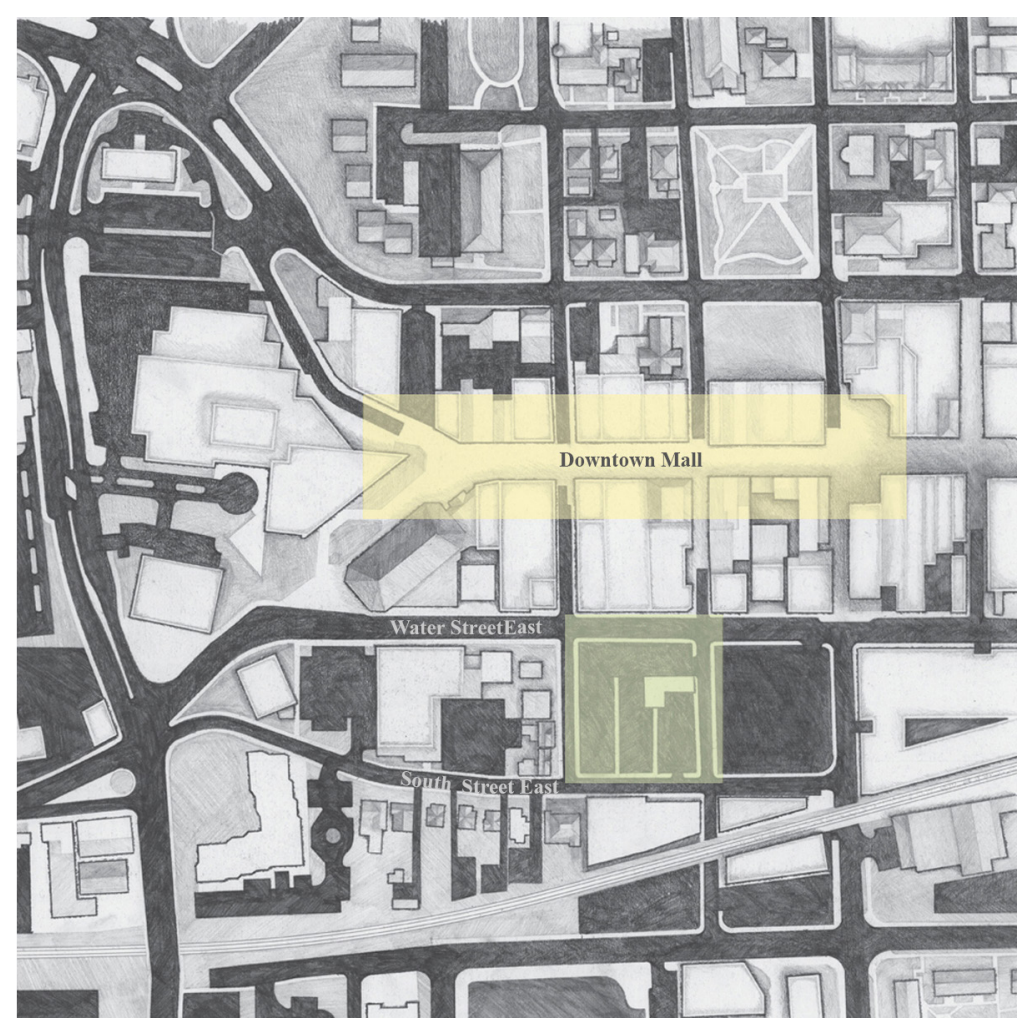

Image 4.12 Plan of blocks shows Downtown Pedestrian Mall (yellow) near Charlottesville City Market (green).

social contributions to the area, the higher economic potential value that new mixed-use development would garner significantly contrasts with the market's limited revenues, and the relative ease of moving the vendors' pop-up canopies to another location.

For over eight years, the city's Office of Economic Development has worked to determine the viability of making the current location of the farmers market its permanent home through the construction of a minimal structure in tandem with buildings of varying uses. In 2007, they sponsored the Market Value design competition, which maintained:

that an open-air market similar, but smaller, than current City Market can coexist with a major mixed-use development at the current site. This approach is not without considerable challenge, but may be a viable option that seeks to enhance the market's presence downtown and recognize opportunities to improve the urban character of the city through quality development. ${ }^{25}$ 


\section{Chapter 4}

Due in part to the 2008 economic recession in the US, the city did not develop the farmers-market-based designs of any of the winning proposals. Questions about the revenue potential of a singular-use but successful farmers market versus fully diversified development of the block and projected substantially larger revenues for surrounding businesses and city government contributed to delaying progress. The community was divided.

Despite setbacks in attaining confirmation from City Council that its current location would be designated as its permanent home, City Market has rapidly expanded over the past decade; vendors' sales continue to rise, in turn increasing city revenues. The waiting list for a spot at the market is over a hundred long-the community continues to pressure local government leaders to increase the size of the market, not make it smaller, as the Market Value design competition brief had proposed. The market has two types of stalls: reserved and non-reserved. Assistant Director Lucy Lamm says that "only four years ago, the non-reserve spots were on a first-come, first-serve basis; now, want-to-be vendors must get on a waiting list at noon on Saturday for the following week's market." ${ }^{26}$ Gail Hobbs-Page of Caromont Farm knows too well that one must exercise patience when trying to get a spot at the market. She started her dairy operation seven years before becoming one of a fortunate few, new vendors to secure a stall in 2009, albeit adjacent to the portable toilets (not an ideal spot to sell her artisanal fresh and aged cheeses). Fortunately, within two years she moved to her present spot near South Street, where she enjoys the camaraderie of adjacent vendors, especially the "dahlia flower guy" next to her. Describing the sense of community among vendors, Gail says, "there are neighborhoods within the market. On my block, it feels like family, and after market we have a beer together. In winter months, I miss them." ${ }^{27}$ She also believes that "the more she sells to individuals, the bigger the community of people who support local food and its benefits." ${ }^{28}$

Likewise, Lee (Sturgis) O'Neill, who sells near First Street where Radical Roots Community Farm has set up their stall since 2002, also feels the multi-dimensional sense of community that Gail describes. Radical Roots Community Farm promotes a larger view of what farming offers; they work to catalyze "positive change by growing high quality, organically grown vegetables, [and educate] about permaculture and 


\section{Pop-Up Canopy Markets}

sustainable agriculture." ${ }^{29}$ They offer group tours and private consultations to educate people about permaculture design and gardening and herbal care. While Radical Roots uses its farm as a platform to educate, Lee says, "The market is where people meet people. We are always trying to expand our community. We come from one hour away, others from further. It is a great place for our kids and other vendors' kids to interact and play together." ${ }^{\circ}$ On my first visit to City Market with Kirsten, Radical Roots' stall caught our attention with its inviting display of colorful vegetables and herbs. Upon entering the stall, we admired multiple containers overflowing with peppers, squash, eggplant, onions, and cabbage; bunches of parsley stacked from waist high to chest level; and numerous signs informing customers of the farm's certified organic status and different ways to purchase: by the pound, the bunch, or the box (see images 4.I3 and 4.I4). As we left the market and walked towards the Historic Downtown Mall, we discussed the ongoing issue of whether the city's leadership would give the market a permanent home.

In July 20II, Market Central, a nonprofit organization created in 2003 to enhance and preserve City Market, asked the Charlottesville City Council once again to address the issue of a permanent home for the market, which they hadn't made progress on since the 2007 design competition. In November 2010, "City Council authorized the formation of a task force to evaluate proposed future home sites for the market, and to make a recommendation to the Council based on these evaluations." "3i The City Market Task Force included citizens from multiple constituent groups including Market Central, market vendors, the

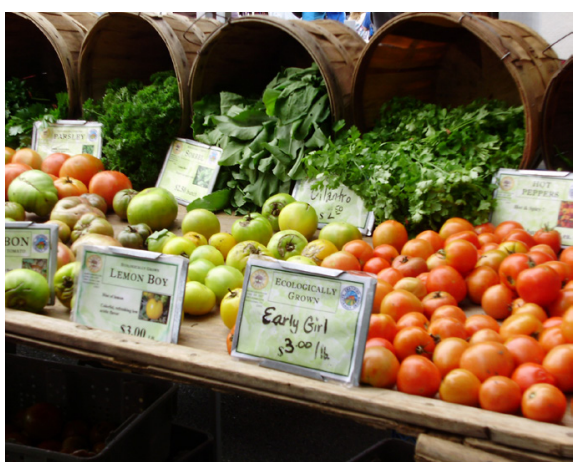

Image 4.13 Bountiful displays at Radical Roots Farm market stall.

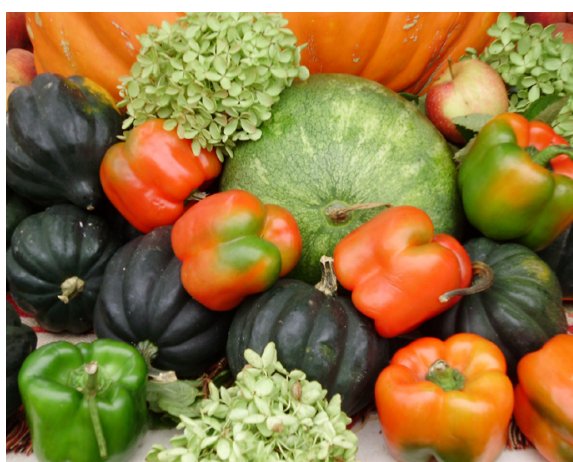

Image 4.14 Colors and textures of fall produce. 


\section{Chapter 4}

University of Virginia, and local business and city employees. Parks and Recreation Director Brian Daly facilitated the group through five months of research and discussion of potential sites and selection criteria, which concluded with the task force's recommendation to City Council in July 20rı: keep City Market in its current location, but make improvements. Internationally renowned public and farmers market consultant David O'Neil, who served as a resource for the task force, concurred, stating:

We looked at a lot of potential sites, none of which are as good as the current location, where (if it were up to me) I would keep the market-in the middle of town. It works, and properly planned as a market square (in a larger market district) could create even greater value for the downtown and surrounding properties. $3^{2}$

City Council expressed interest in the market district concept, but six months passed without action. Market Central continued to pressure City Council and, in May 20I2, the city requested to hire a consultant to determine the project's scope and feasibility. A few months later, the city hired two local firms and Maine-based Market Ventures Inc. because of their specialized experience with public market districts and farmers market expansion planning. Within a year, Market Ventures Inc.'s Ted Spitzer and his consultant team presented a feasibility study with two options-one to stay put, one to move-for a permanent downtown home for City Market. 33

The University of Virginia's Jefferson Public Citizen Scholars also conducted research on City Market over a period of seven weeks. When the group asked citizens how they viewed City Market's contribution to the community, 6r.3 percent strongly agreed that "it provides a place for community members to convene; a valuable public space," while 90.7 percent strongly agreed that "it provides a venue to support local farmers and the local economy." 34 Certainly the first is necessary for the latter, which can be evaluated as generating social capital and appreciated revenue, while also sustaining diversity of jobs in the city and surrounding region.

In mid-September 2013, my husband and I visited City Market during a trip to Charlottesville. We arrived near the end of market hours, but the market still buzzed with activity. We happened upon 


\section{Pop-Up Canopy Markets}

Caromont's stall, where Gail Hobbs-Page chatted with a customer while an intern offered tasty morsels of Esmontonian and feta, both made using goat "milk from animals raised on the principles of natural husbandry and grass-based management." ${ }^{35}$ In a later phone conversation with Gail, she expressed that she feels it's important for her to be at the market during open hours, as "nobody knows the product like the one who makes it." She also emphasized the significance of the layout of her stall, a singular table positioned at the front of the stand, because, "unlike produce vendors who have lots of color and a variety of shapes to attract the shopper, [she] must provide tastings and engage the customer." ${ }^{36}$ Gail accomplishes this by displaying a plate of toothpick-ready, bite-size pieces to entice shoppers to taste her cheeses. Her methods prove effective-the day my husband and I stopped by on our way out of town, I tasted a flavorful morsel of feta and happily purchased a tub filled with a hunk of the cheese submerged in brine.

A month after my impromptu visit to the market, I learned that City Council had met in October to discuss the two alternatives proposed by Market Ventures Inc. The council ultimately agreed "to seek proposals from firms to develop the existing City Market on Water Street as a mixed-use project that also would provide an improved home for the market." ${ }^{37}$ I was intrigued to learn that locals surveyed by the city expressed a preference for the market remaining pop-up canopy-based instead of moving inside a building - they voiced more interest in a permanent location and amenities for the customers, such as places to sit, trees offering shade, and bathrooms. During the October 2013 council meeting, the director of the Office of Economic Development, Chris Engel, advised the council to obtain a lease agreement for an alternative site on Garrett Street that the market could use during development of the original site. Even this proposed solution caused controversy, however, as moving further away from the downtown mall and the safety issues of an adjacent train track concerned vendors. As the 2013 market season ended, City Market appeared to have finally found a permanent home in its current location. Although many characterize the progress as too slow, significant progress was made in the following year. In summary, city leaders requested proposals from qualified developers, then four were selected to make a presentation to City Council during one of its work sessions. Local residents were given the opportunity to 


\section{Chapter 4}

ask questions at a subsequent public hearing followed by City Council directing staff to proceed with the Market Plaza proposal. $3^{8}$

From my review of the architectural renderings, the new design for City Market will transform the pop-up market into an open-air pavilion market located on a civic plaza of a new nine-story L-shaped building that includes six levels of residences, two levels of office space, and ground floor retail. There is much concern by the community about the privately owned but public-use plaza where the market would set up, such that the city's Department of Parks and Recreation secured a 99-year lease to operate City Market on the new plaza whether or not the property changes owners.

Four years later the whole deal fell through and there currently are no future plans for any type of development. City Market remains largely unchanged physically, but it is more prosperous than ever. Sales exceeded $\$ 2$ million in 2018 and the number of vendors expanded from IO5 to $127^{39}$ (see image $4 \cdot 15$ ). For me this saga validates a proposition framed in Chapter I; farmers markets belong to the vendors and people who shop there - the market community. It also illustrates the architecture of place that can be created by the temporary pop-up canopies, due to the location filled with our histories and memories. As Lucy Lippard

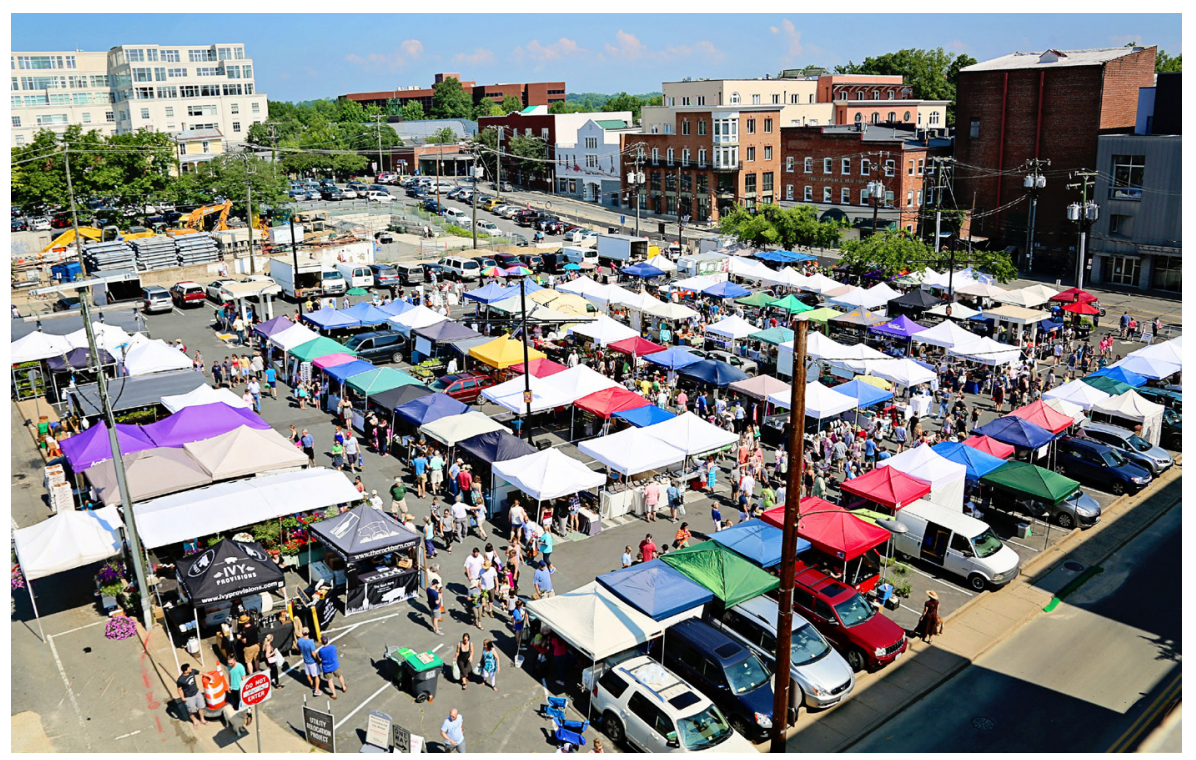

Image 4.15 View from parking garage towards farmers market. 


\section{Pop-Up Canopy Markets}

reminds us, "It is about connections, what surrounds it, what formed it, what happened there, what will happen there." ${ }^{\circ}$

\section{Staunton}

The opening of Staunton's farmers market in 1993 followed a dozen years of adaptive reuse and revitalization of the Wharf Historic District, which is comprised of twenty-five late-nineteenth-century warehouses located between Johnson Street and the C\&O Railroad. Between the I950s and I970s, the city destroyed many buildings in the Wharf Historic District due to lack of use and maintenance. The Historic Staunton Foundation, founded in I97I, began a movement in the rg8os for the preservation and renovation of Staunton's five historic districts. Over two decades later, Staunton's Farmers Market thrives and boasts over three dozen diverse producer-only vendors who sell on Saturdays from April through November, and Wednesdays May through September. On Staunton Farmers Market's web site one patron's post indicates the foundation's success. It reads, "The Staunton Farmers Market is more than a collection of vendors; there is an air of small-town Virginia, a social atmosphere that in itself is worth the trip." ${ }^{4}$

Fortunately, the Historic Staunton Foundation appointed local urban planner and architectural historian Bill Frazier to be director, and he led the community effort to create a comprehensive revitalization plan for the Wharf District with grant money the foundation received from the National Trust for Historic Preservation. Frazier galvanized a group of citizens who, with the professional expertise of landscape architect Gary Okerlund, crafted a proposal for the adaptive reuse of the warehouses as residential, retail, and office buildings. ${ }^{42}$ Around the same time, the Historic Staunton Foundation received a National Endowment for the Arts (NEA) grant to study streetscapes throughout the city and propose streetlights, signage, paving, trash cans, etc. that characterized historic-era designation, such as Victorian for the downtown and Industrial for the Wharf area. Tom Roberts, newly elected mayor at the time, supported the Historic Staunton Foundation's wide-ranging revitalization proposal by allocating $\$ 500$, ooo of municipal funds to the project in 1980.43

In addition to rehabilitating the Wharf District's warehouses, the Foundation revitalized much of the buildings' exteriors as well. They 


\section{Chapter 4}

widened the sidewalk directly in front of the buildings along Byers Street to accommodate outdoor dining, and built a new twelve-footwide, brick-paved sidewalk perpendicularly midway along the buildings' frontage. The brick sidewalk, which bisects the adjacent municipal parking lot, provides a strong visual, physical link to the historic downtown. The tree-lined, hundred-foot long walkway ends at a fountain at the intersection of Johnson Street and North Central Avenue. The Historic Staunton Foundation's exhaustive renovation laid the groundwork, quite literally, for the present-day farmers market that sets up on the brick-paved sidewalk and on the western side of the city-owned parking lot (see image 4.I6).

The market sits adjacent to downtown's mixed-use Beverley Historic District to the north and residential neighborhoods of the Gospel Hill and Newtown Historic Districts to the east and west, respectively. The market's close proximity to these areas allows for many of Staunton's

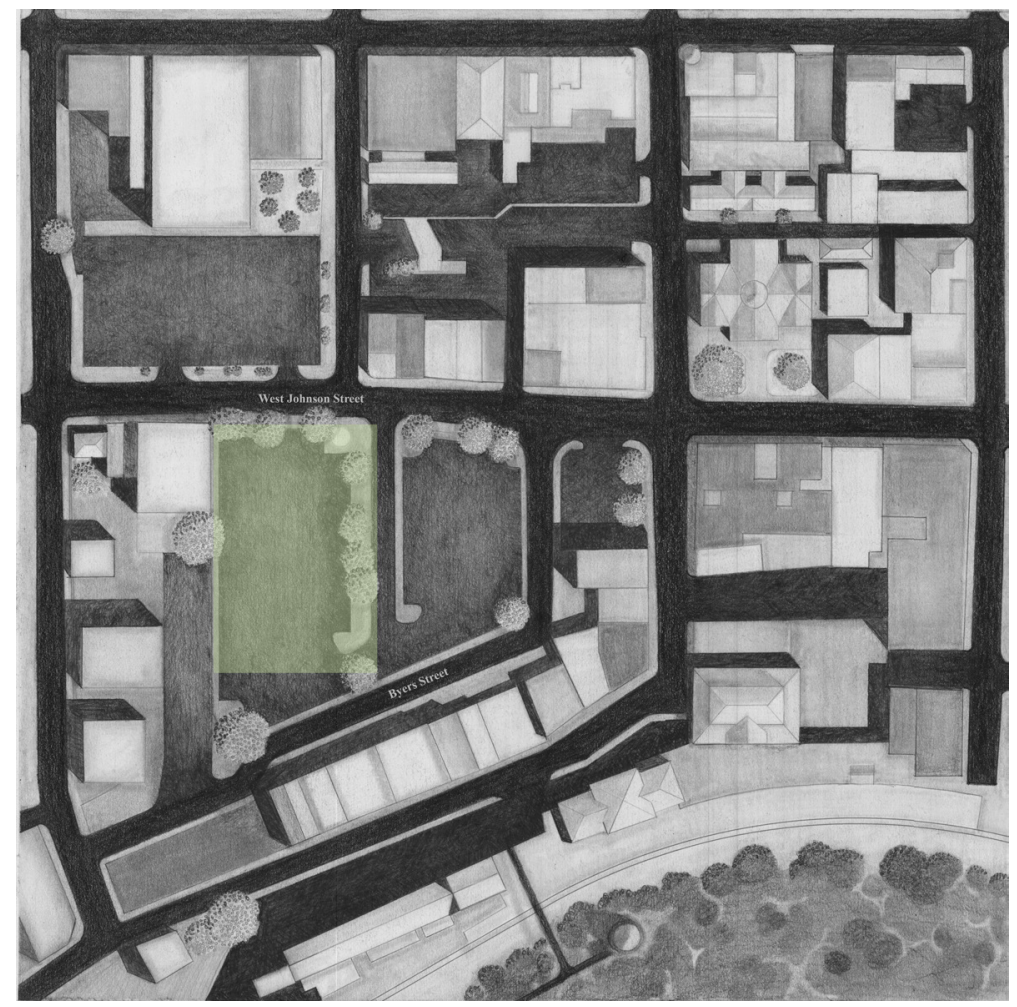

Image 4.16 Plan drawing of blocks surrounding parking lot home to Staunton Farmers Market. 


\section{Pop-Up Canopy Markets}

residents and workers to reach it via a short walk or an even quicker drive. The Beverley neighborhood is comprised of more than one hundred and fifty Victorian-era buildings tightly packed into eleven blocks; Newtown and Gospel Hill are comprised of late eighteenth- and nineteenth- and early-twentieth century residences, many of them designed by renowned local architect T. J. Collins. ${ }^{44}$ The area's architectural beauty and charm haven't gone unnoticed-in 1995, Staunton gained status as a Virginia Main Street Community, followed by an award as Great American Main Street Community in 2002, and accolades as one of the top twenty "Best Small Towns in America" by Smithsonian magazine in 2012.45 The American Planning Association designated Staunton as one of its "Great Places in America" in the December 2016 issue of Planning Magazine. ${ }^{46}$

In 1993 Bill Frazier (of the Historic Staunton Foundation), his wife Kathy, and a few of their friends asked the city and county government to each contribute a thousand dollars for the creation of the Staunton Farmers Market. In return, they promised to donate a thousand dollars of their own as well as to organize and operate the market on Saturday mornings. They argued that the market would produce three positive outcomes: (I) a new source of income for local farmers, (2) fresh, local food for residents, and (3) economic development opportunities for adjacent areas. ${ }^{47}$ The group researched rules and regulations of other markets and decided that theirs would be "producer-only." Bill considers implementing this rule as the most important decision they made when starting the market, as "producer-only means that all the vendors grow or make what they sell-there is absolutely no resale of food grown or made by someone else." The producer-only rule extends to vendors who sell crafts and all other products; they, too, must make everything they sell themselves-Bill was clear from the start that the farmers market was not to be a "flea market." $4^{8}$ The city opened a bank account on behalf of the market founders, and the farmers market opened in the spring of 1993 with six to ten vendors each Saturday.

As I drove into the parking lot off Johnson Street one September morning, I observed an assembly of a dozen pop-up canopies interspersed amidst the allée of trees along the aforementioned brick-paved sidewalk, and upon first impression, thought the market looked less impressive than its website claimed-I could see just about as many shoppers as pop-up canopies (see image 4.I7). However, once I began to 


\section{Chapter 4}

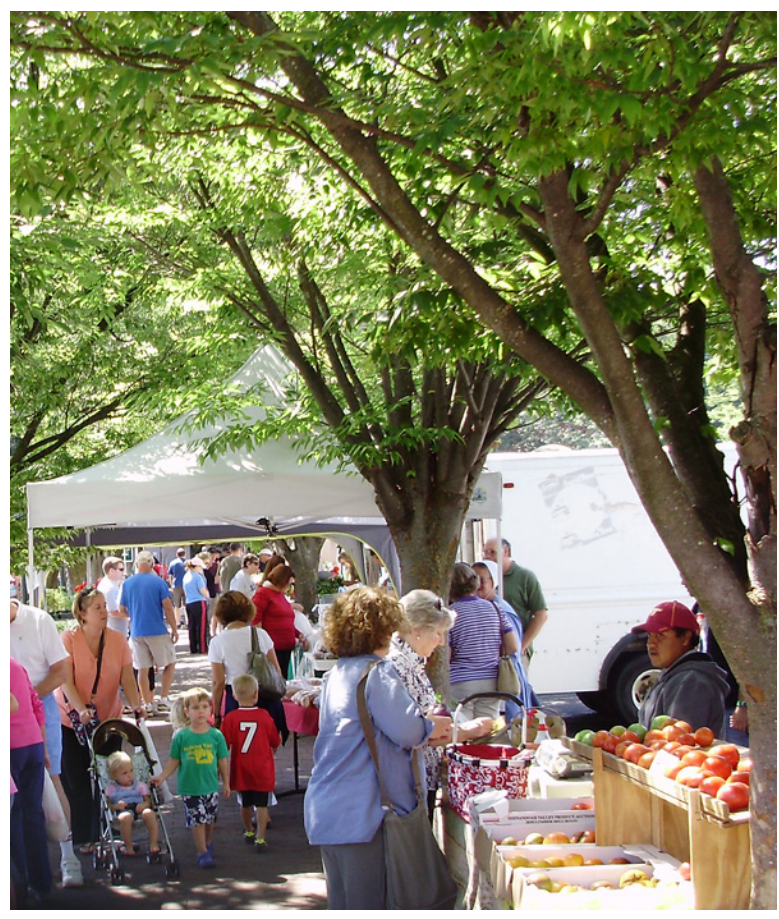

Image 4.17 Staunton Farmers Market pop-up canopies set up under allée of trees.

walk around, another two dozen canopies in the parking lot came into view, bustling with shoppers of all ages. Parents used strollers as shopping carts, while their small children walked alongside holding onto the stroller's handle. One child held the hand of his father who pulled a red wagon filled with bags of produce. Elderly people walked with canes or took in the activity while pushed along in a wheelchair by a family member or friend. Dogs on leashes stood patiently alongside their owners as they chatted with other shoppers. I recalled the comment on the web site about the small-town, social atmosphere and agree that Staunton's market is indeed a vibrant place of community gathering (see image 4.I8).

As I scanned the individual vendor displays, my attention was drawn to a cowhide draped over a table that held a refrigerated display case containing various cuts of meats and a sign hanging above that asserted, "Longhorn Beef - It's What's for Dinner" (see image 4.Ig). Across the twenty-four-foot wide aisle, another sign declared, "Weird Dude's Plant Zoo - Awesome Perennials," only to be challenged by another vendor's sign claiming, "Home to Amanda's FAMOUS Granola Bars - Just Plain 'Ol Good." 
Pop-Up Canopy Markets

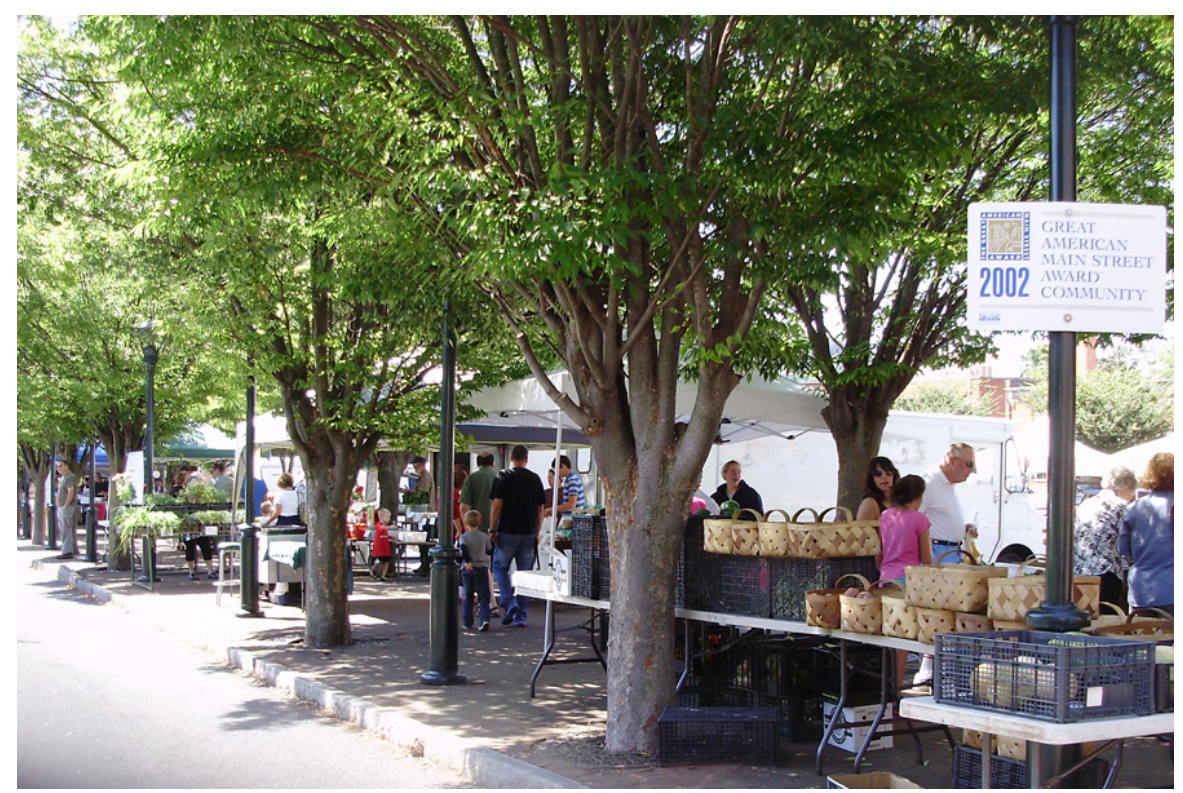

Image 4.18 Entrance to Staunton Farmers Market.

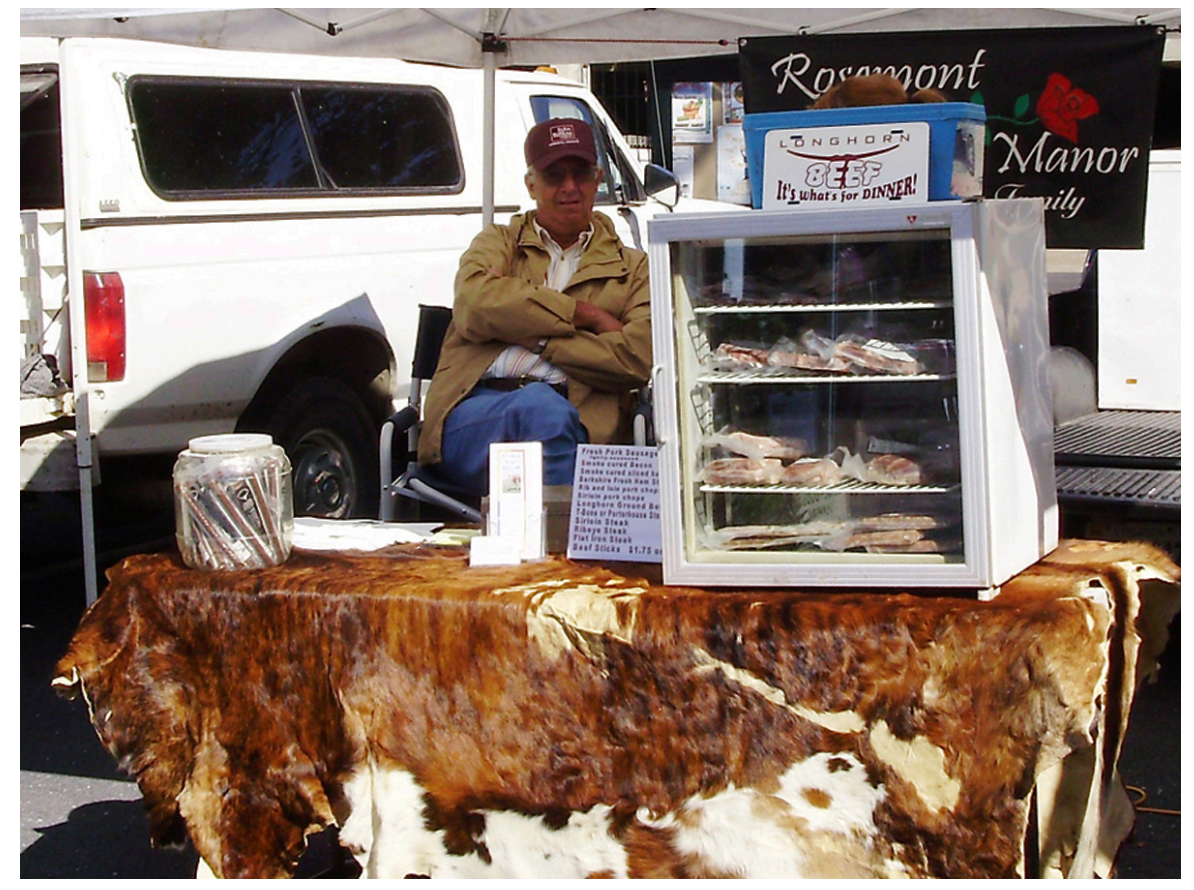

Image 4.19 Longhorn Beef stall. 


\section{Chapter 4}

The all-caps accentuation of "famous" prompted me to ask the woman behind the table what makes the granola bars so fabulous.

Amanda Rhodes introduced herself and handed me a brochure that explained her sign's claim. At nine years old, she started making the bars for sale at the farmers market from a recipe that her mom found. Amanda's parents, Barbara and Tom Womack, began selling at Staunton's farmers market in 1993 when they established Homestead Hill Farm in nearby Middlebrook, Virginia. At some point, Amanda decided she wanted to pursue a path other than that of a second-generation market vendor, so she stopped making the granola bars and selling them at the market. It wasn't until Amanda closed her shop that she realized her granola bars' fame; customers told her that they bought them not just for themselves, but also sent them to friends and family members who did not live in the area, some shipped as far away as Canada and Germany. To everyone's delight, Amanda resumed making granola bars and selling them at her own market stall-Country Rhodes Produce \& Bakery, which now includes sourdough breads, seasonal produce, and eggs. She and her husband, Tyler, started farming in Springhill, Virginia after marrying in 20I0. She displays her baked goods on tables, while her vegetables fill multiple shelves of a wooden structure built by Tyler. In between sales, Amanda immediately refills baskets and trays because she's observed, "the fuller, the better the product will sell"49 (see image 4.20).

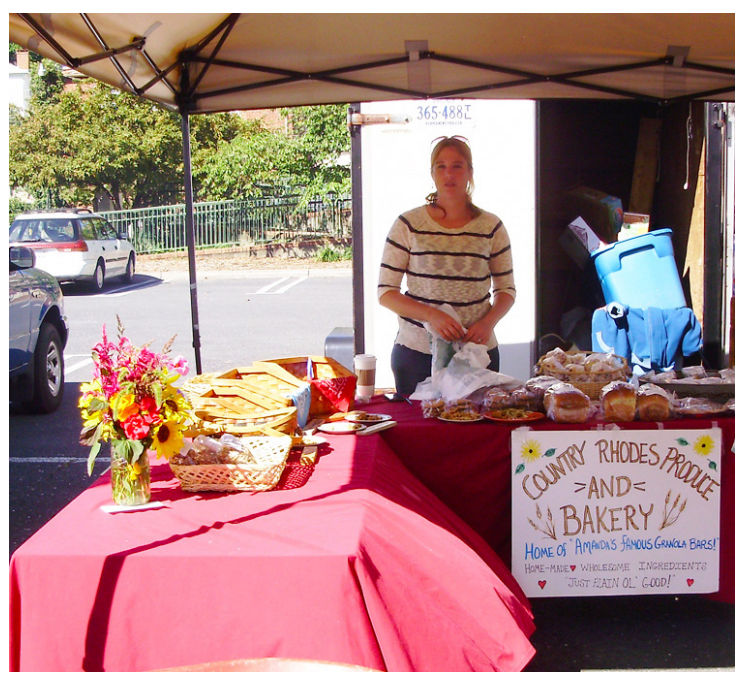

Image 4.20 Amanda Rhodes greets customers with a smile. 


\section{Pop-Up Canopy Markets}

The Womacks, illustrious veteran vendors of Staunton's market, offer an array of produce, lamb, chicken, and eggs at their stall, and always display unabashed enjoyment for their choice to farm and sell at the farmers market. Barbara admits that they've faced trying times and have to work extremely hard, but says that her family "counts it a privilege to make a living doing what we love." $5^{\circ}$ Through conversation while at the market, and later through email, Barbara described how selling at the market involved informing shoppers about the difference (and better quality) of their food and farming practices. Tom added that he "has not found any local food-selling venue better than the farmers market where people can learn about the origins and process of growing or producing the food they purchase and ultimately eat." ${ }^{5}$ The printed brochure that they hand out at the market exclaims, "KNOW YOUR FARMER, KNOW YOUR FOOD" across the top.

Peg Davis of Snow Spring Farm has equal affection for farming, which she's done for over forty years, as well as selling at Staunton's market, which she's done for fifteen years. She once told me that the market is the "Saturday morning place to be in Staunton!" She sees it as more than just a place for business transactions. "As vendors, we know our regular customers very well, and miss them terribly when the market closes for the winter. We know about their families, their kids, their dogs. Every Saturday is a reunion.". $5^{2}$

To encourage new customers to walk under her ten-by-ten-foot canopy, Peg configures three tables in a U-shape with large price signs clearly visible from a distance for baskets filled with in-season heirloom vegetables, fruit leathers (a dried fruit snack), and homemade pies. She also prominently displays her two signature items made with hot peppers: Datil Hot Pepper Sauce and Habanero Butter. On her relationship with customers, Peg says:

It is very important to me to make a real effort to learn new customer's names, to learn what they do, what they like, and what they cook. It is by far the most rewarding aspect of the market for me-selling what I grow and bake and create to people who really appreciate it. 53

Peg describes yet another example of how farmers markets enable community members to build lasting relationships that endure beyond the borders of the market. 


\section{Chapter 4}

Many other vendors echo Peg's sentiment about the market's community-building power. A veteran vendor from the market's origins, Susan Randall of Elk Run Farm, also earnestly values the friendships she shares with her customers; she says, "We know most of our customers and what's going on with them. Some of our customers have been at our farm for friendly visits and we have dined at a few of their homes." ${ }_{54}$ Christie Huger of Mountain View Farm, another longtime vendor, describes the sense of camaraderie between vendors at the small-town market: "I don't think it's the case at all markets, but we do have a sense of community at ours. There is genuine caring among us for others. You see it with the new or younger vendors interacting with longtime and older ones." 55

Market patrons share this sentiment, as summed up by Sophie Cantell Lambert. She says:

In March after a long winter, residents of Staunton start chatting excitedly about how the farmers market will be opening soon. Then, from the first market Saturday in April until late November, it is a weekly social affair. If you live in or near Staunton, you $<\mathrm{sc}>\mathrm{CANNOT}</ \mathrm{sc}>$ go to the market without seeing at least five people that you know and your children will immediately find their school friends sitting watching the weekly musical act, eating pupusas or other yummy snacks served at the market, drawing with chalk or climbing on the nearby Statler Brothers stool statues..$^{6}$

From the outset, vendors at the Staunton market have mostly self-governed with only occasional assistance from the city manager. Susan Randall, in addition to selling at the market, serves as chair of the governing Farmers Market Committee, a group primarily comprised of vendors. A few dedicated customers also serve on the Farmers Market Committee; Susan explains, "occasionally, we have to ask for help from our customers to get support for policy changes from the city." ${ }_{57} \mathrm{Peg}$ Davis served on the committee for nine years; of her tenure, she says, "I feel strongly that my role on the Committee is to help preserve the integrity of our wonderful market. It's the most important thing I do

off the farm." $5^{8}$ The Staunton Farmers Market's economic success and its facilitation of a resilient bond between citizens and farmers has made it a "model market"-it directly influenced the organization of new public 


\section{Pop-Up Canopy Markets}

farmers markets across Virginia: from nearby Monterey, Lexington, and Broadway to across the state in Williamsburg, and even as far as Birmingham, Alabama. ${ }^{59}$

Throughout my research on pop-up canopy markets, it surprised me to discover that many of these large markets, including Alexandria's, resist efforts to build a permanent structure. They instead value the sense of place that comes not from a permanent building but from the very presence of people of all ages and backgrounds who come together regularly for the simple and mundane activities of life. When you think about it, it is not all that different from nomadic tribes who return annually to the same places to hunt and gather because they know that there is food to be had in abundance. Smaller markets like Staunton's have considered building a permanent structure but haven't done so because they value the temporary, festive feeling of an outdoor, makeshift setting. Absent the architecture of a physical structure, the landscape and encompassing built environment provide a sufficient setting for generating meaningful memories of the rituals that farmers markets sustain. Perhaps it is for both of these reasons that pop-up markets are the dominant type of farmers market during the past three decades of tremendous growth in numbers and prosperity across the country. They dominate due to several factors: I) low cost and portability of canopy, tables, etc.; 2) ease of set-up / takedown; and 3) municipal parking lots offer no-cost location and adjacent parking for shoppers. Perhaps they are also part of a larger trend of temporary events, such as food truck rodeos and pop-up art galleries. 



\section{CHAPTER}

\section{5}

\section{MOBILE MARKETS \& URBAN FARMS}

OMETHING THAT CONTINUES to amaze me after years of visiting and studying farmers markets is the amazing positive impact they have on people's lives and, by extension, on the communities in which they live. Recent efforts of farmers are now taking local food found at farmers markets to communities that lack access to fresh healthy food. We are seeing the emergence of a new type of market, one that can be adapted to almost any environment. This type is aptly called the "mobile market," and it has the potential to be a significant gamechanger for equitable access to nutritious and affordable food.

Many of the new mobile markets are the retail component of an urban farm, while others are in collaboration with a community of local farms owned by others. The mobile markets featured in this chapter are sourced by small farms located within their city's boundary amid mixed-use neighborhoods on what was once underutilized land, such as parking lots or areas within public parks. Some mobile markets source from farms that are within the region but not necessarily within the city limits. Urban farms differ one from another as much as their rural counterparts, but all urban agriculture is growing or producing food in a city or heavily populated municipality. These new urban farms featured in 


\section{Chapter 5}

this chapter are changing the architecture of place at the urban scale, while mobile markets are transforming multiple locations throughout neighborhoods into community gathering places on a routine basis.

The mobile market is a large vehicle-often a transit bus, school bus, or a service van-that has been substantially but relatively easily converted into a farmers-market-on-wheels. Each one has its distinct identity within the community it serves, whether curbside on a street or in a parking lot or alongside a park. Typically, they operate throughout the week, making multiple stops in neighborhoods each day. At each stop, the parked vehicle is swiftly transfigured into a small grocery store- a mini-mart but with wholesome food. An awning hinged to its side easily lifts and cantilevers from the bus. Tables unfold beneath and are promptly covered with produce. Some vehicles have a metal track on the side that allows multiple wire baskets full of fruits and vegetables to easily attach. Others have shelves that fold down to support many containers of fresh food. Some are completely contained inside the vehicle, with stacked rows of shelving on either side of a center aisle. Often, off to the side and near the front of the bus, someone is seated at a table where they provide nutritional information and customer service to patrons, including federal Supplemental Nutritional Assistance Program (SNAP) shoppers.

Mobile markets are similar in many ways to pop-up canopy markets. The structures are temporary and the food is immediately visible and accessible. The awning serves the same function as the canopy, providing shade from the sun and shelter from the rain. Unlike canopy markets, however, mobile markets make use of the features provided by a large transport vehicle. Most often, the exterior of a mobile market serves as a moving billboard. On renovated buses, the name of the market usually appears in large letters covering the windows, doors, and sides seamlessly.

Although this type of market is relatively new, its numbers are growing fast. One very successful pioneering mobile market in Charleston, SC, called Lowcountry Street Grocery, aims to replace the "brick and mortar" paradigm by traveling throughout the greater Charleston metropolitan area to underserved communities. Similar to Charleston's mobile market, Fresh Truck began roaming the streets of Boston in 20II, and its founders Josh Trautwein and Daniel Clarke boldly claim on 


\section{Mobile Markets \& Urban Farms}

their web site: "Fresh Truck is out to radically impact community health by getting food to those who need it most." In fact, Fresh Truck offers high quality fresh food at 20 percent less than average food store prices. However, to achieve the scale of change they aspire to they have enlisted a diverse range of partners, not only for operations and logistics but also health centers, hospitals, educators, and other community outreach and health organizations, to combine their resources to promote nutritional and cooking literacy through cooking demos and food-health workshops, and facilitate awareness of mobile market locations.

Observing the breadth of the mobile market's impact on a community, Ken Reardon, University of Memphis professor of city and regional planning who helped spearhead Memphis's The Green Machine Mobile Food Market, commented, "the community response has been wildly enthusiastic, particularly by a lot of older people, folks with disabilities, women who are involved with child care and elder care and who don't have cars. These people who haven't been able to get out to the store in months and, in some cases, years."

In each case, these markets share the same eight scales of interaction and interface found in the other market types, but differ significantly in two ways. One formative difference is that the multiple stalls of individual vendors characteristic of the other markets now have been consolidated into one vehicle. One farm takes on the responsibility for supply of fresh goods to the mobile market and for its operation, but also sources food from other nearby farms. In one situation it takes the form of a collective of farmers, and in another one as a farm alliance. Nonetheless, the intimacy of knowing the farmers that grew your food, and the sense of community among shoppers is similar to other types of markets. Another distinction is that the farm itself becomes part of the identity of the community-a landmark of its own.

I am fascinated by how this type of market contributes in unique ways to placemaking and community building. It appears that mobile markets situate themselves in the same type of spaces where the pop-up canopy type of farmers markets locates: public places like parking lots of schools and libraries as well as civic plazas and public parks. However, they also set up in private parking lots of senior centers, low-income housing developments, and places of religious assembly. My impression is that a sense of community arises out of shared pride of empowerment 


\section{Chapter 5}

to improve one's health through enjoyment of tastier, more nourishing food. Many older people express appreciation of their capacity to regain access to favorite fresh greens, such as collards and kale, that they enjoyed eating while growing up. I was surprised but heartened to learn that some kids have just now tasted the sweetness of their first apple or peach and found delight in eating healthy food. I find mobile markets foster place-making akin to pop-up canopy markets in the way their existence transforms streets, parking lots, and parks into places to just hang out, but with purpose and shared meaning-making.

Following discussion here of a couple of mobile markets, I talk about a few urban farms that are serving nearby residents and restaurants by transforming underutilized land and rooftops into farm plots. In these ways, mobile markets and urban farms are becoming integral parts of the neighborhood fabric of our cities.

Urban agriculture is not new to American cities; however, it has been largely relegated to the outskirts and beyond, as cities grew and industrialized. However, for various reasons a range of individuals and groups from restaurateurs to activists are bringing farming back into cities in unexpected places. Just as exemplary mobile markets have spawned associated urban agriculture, two urban farms featured in this chapter are part of allied programs of previously discussed case-study markets in Durham and Cincinnati. Another version of emerging urban agriculture worthy of mention is in alliance with subsidized housing projects- City Farm in collaboration with Cleveland's Cuyahoga Metropolitan Housing Authority, and Chicago Lights Urban Farm in collaboration with Chicago's Cabrini-Green residents. One other new form of urban agriculture that I touch upon is located in an unlikely place: atop Chicago's premier convention center, hence its name, The Rooftop Garden at McCormick Place West.

In these ways, urban agriculture is becoming a part of a city's future as it becomes integral to urban infrastructure and its equitable food access and distribution. This is in part due to the increase in knowledge and acceptance of the benefits of eating fresh food, but it also is a result of a surge in educational opportunities about cultivating land that are accessible to and achievable by most everyone. These relatively small areas of land production yield positive outcomes, including the economic value of new employment and supplemental income prospects, 


\section{Mobile Markets \& Urban Farms}

health benefits from consuming nutritionally advantaged fresh food, and socioeconomic benefits of education about growing and producing food in ways that cultivate the value of meaningful engagement with people of all ages and backgrounds.

Arcadia Center for Sustainable Food and Agriculture oversees two programs: operations of Arcadia Farm and its Mobile Market launched in 2012, and in the years since has changed the lives of countless DC residents. The twenty-eight-foot-long mobile market serves eleven neighborhoods all over the city, making weekly stops at Hendley Elementary School, Parkside Unity Health Center, Chinatown Wah Luck House, LeDroit Park, Congress Heights Senior Wellness Center, Bellevue Library/ Community of Hope Conway Health Center, Edgewood, Oxon Run Park, Anacostia, and Deanwood Recreation Center. The neighborhoods it serves typically have high SNAP usage, low car ownership, and are at least a mile from a grocery store that can support a healthy diet. ${ }^{3}$

When the bus-painted bright green with "Mobile Market" in bright orange over the front window- arrives, residents quickly gather in anticipation of the healthy food they will purchase with their SNAP benefits (see image 5.I). Some days there is additional value- a cooking demo, a recipe, nutritional information. Often a dozen people linger under the shade of the matching bright green canopy and chat about cooking their fresh produce. Price lists, hand-written with markers, lean against the bus. Items include fruits and vegetables, herbs, pastured eggs, grass-fed and pastured beef, pork, organic milk, cheese, handmade

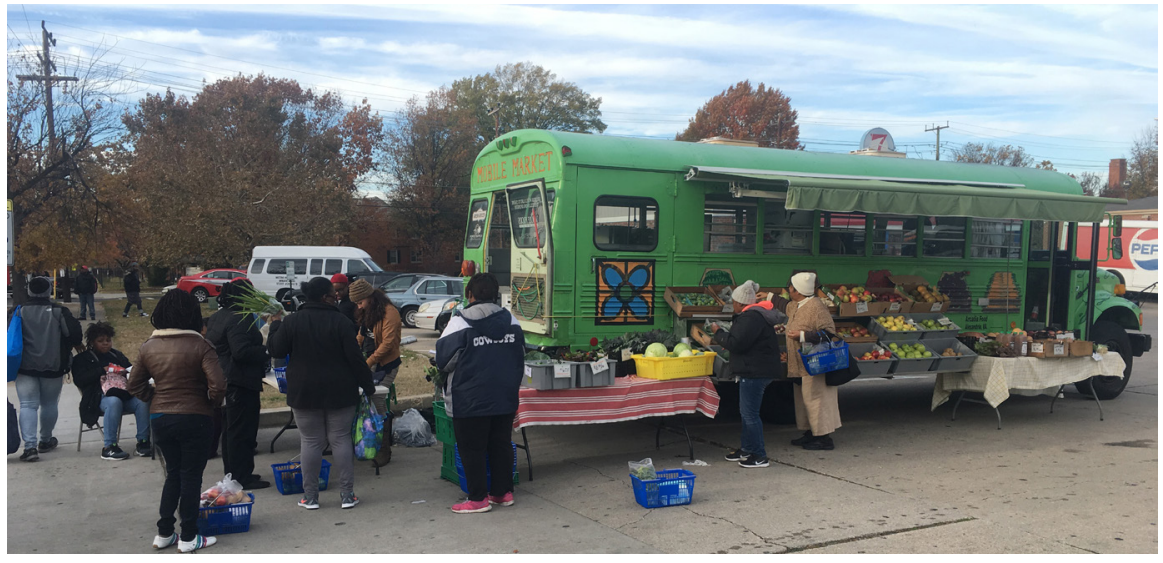

Image 5.1 Arcadia Mobile Market converted school bus. 


\section{Chapter 5}

bread, and honey (see image 5.2). A chalkboard hangs over the bus windows touting "BUY FRESH, BUY LOCAL" And although most of the sites are parking lots and the transformation into an architecture of place is physically only temporary, it remains strong in shoppers' minds as they eagerly await the mobile market's arrival week after week. Another one of Arcadia's mobile markets is a converted refrigerator truck that has similar features to their first one (see image 5.3).

Data documenting Arcadia Mobile Market's impact is astounding; in their annual report, Executive Director Pamela Hess reports that "more than 70 percent of our SNAP transactions are with repeat cus-

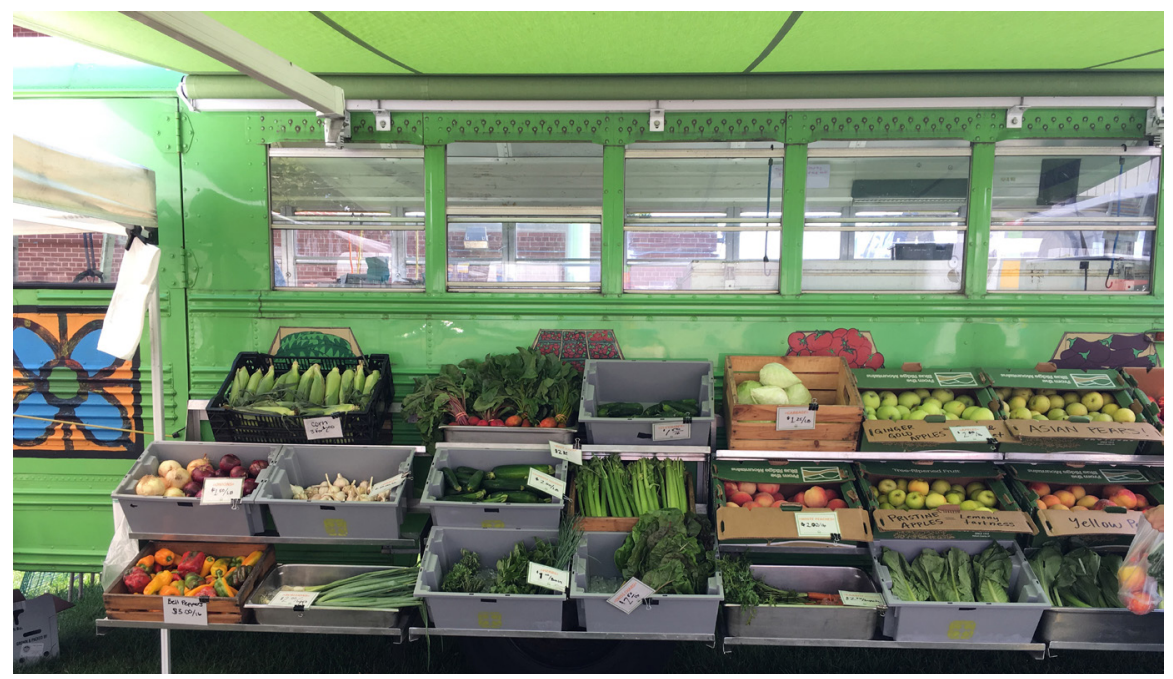

Image 5.2 Arcadia Mobile Market exterior display.

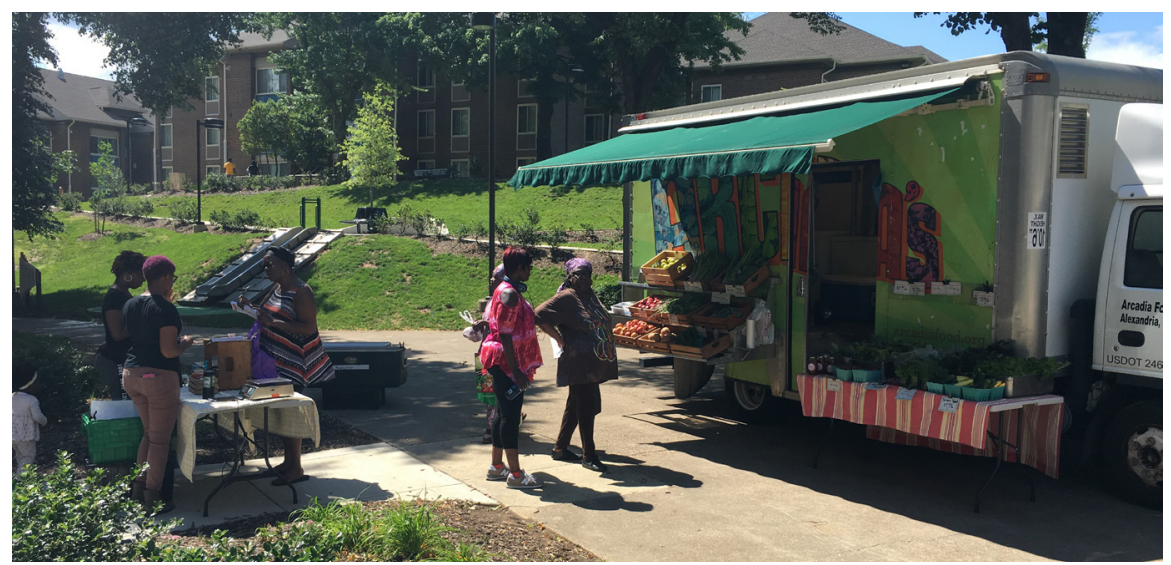

Image 5.3 Arcadia Mobile Market converted truck. 


\section{Mobile Markets \& Urban Farms}

tomers. In total, more than 50 percent of our sales are with low-income customers using some form of food assistance." 4 Recently in an email she noted, since 2012 Arcadia has sold and distributed more than \$I million in fresh healthy locally grown foods in under-resourced neighborhoods, a $500 \%$ increase in demand since it began serving DC food deserts. ${ }^{5}$

Over the years, Arcadia has formed partnerships with compatible DC organizations in pursuit of a more equitable system of growing, distributing, and educating DC residents about the benefits of eating fresh food. Arcadia Mobile Market sources a lot of its food from its namesake 3 -acre urban farm in Alexandria, VA, but a significant collaborator is Common Good City Farm (CGCF). This diversifies their business and gives them new customers in a market that they would not otherwise reach, with no financial risk because Arcadia pays them up front for their product. "To supplement our offerings, the Mobile Market sources from Arcadia's agricultural partners, all of whom are within about 125 miles of DC and include local sustainable producers such as Bainum Foundation Farm, Ayrshire Farm, Chocolate \& Tomatoes Farm, Three Springs Fruit Farm, Tuscarora Organic Growers Cooperative, Local Food Hub and The Common Market." ${ }^{\prime \prime}$ This is another way that farmers markets are building community within their region beyond market days.

CGCF is located in northwest DC adjacent to LeDroit Park: a third of this neighborhood's residents live in poverty, one in five is overweight, one in ten has diabetes. Since January 2007, CGCF has provided over ten tons of fresh produce to the community, engaged over 2,700 adults and 4,500 young people in educational programs, and hosted over 3,000 volunteers. Not surprisingly, Arcadia's success has been contagious. In a mere half-dozen years, they have provided free consultation to more than fifty like-minded organizations in other towns and cities.

Notably, the money needed to convert Arcadia's bus to a mobile market was crowd-funded through Kickstarter, a web-based platform for raising money for start-up ideas without solely sourcing through government grants and/or corporate capital funding. But Arcadia is not alone in its achievements. Many organizations have also funded the transformation of a vehicle for mobile market ventures by raising monies through this internet-based social-media method of engaging tens of thousands of individuals. For me, this is yet another indicator of how farmers markets nurture community, albeit virtually. 


\section{Chapter 5}

Civic Works, a nonprofit working to strengthen Baltimore's communities, has operated its Real Food Farm since 2009 in the bucolic 266-acre Clifton Park. Civic Work's mission for its Real Food Farm Mobile Market is to "grow fresh produce on eight acres in east Baltimore and distribute to its neighbors throughout the city."7 Their goals include bringing fresh, pesticide-free produce to neighbors who have limited access to food through community partnerships and a Mobile Farmers' Market. They sell their produce at ten stops in Baltimore's east and west side food deserts, including schools, senior centers, and community centers. At the farm they demonstrate sustainable alternatives to conventional farming and promote urban agriculture as an economic engine in Baltimore by serving as a training ground for the next generation of urban farmers. ${ }^{8}$

Real Food Farm Mobile Market's first vehicle (2016) transformed an old newspaper delivery truck into a market-on-wheels that offered flexibility to experiment with the layout and display of its food. They added an extra seat up front to accommodate another person on market days. The interior is lined with shelves for storing produce and extra supplies (e.g. shopping bags, staplers, receipt paper, pens, chalk). Two chest refrigerators (with backup generator) were installed for meat and eggs. The key part of their retrofit was a pull-out drawer that is used as the base for the market stand (see image 5.4). Upon arrival on site, they simply roll up the back door of the truck, set up a camper awning, and pull out the drawer, already full of beautifully stacked fruits and veggies. All in all, setup takes about 5 to ro minutes. There is a side awning for extra displays on folding tables when needed. Success indicators tracking the mobile market from inception to October 2016 show $45^{2}$ total home deliveries, $\mathrm{I}, 527$ total markets, 8,829 total transactions, and $\$ 12,883.08$ in SNAP funds matched with $\$ 65,250.50$ total sales. ${ }^{9}$

The following year Real Food Farm transformed another truck to expand the mobile market program and try something new. Ultimately, they purchased a Chevy Astro refrigerated van, a smaller vehicle that allows them to set up mini-sidewalk markets. While the size allows greater flexibility in where they go, it takes longer to set up and break down-although it is still only a ro to I5 minute setup. ${ }^{\text {Io }}$ Unfortunately, the group has sold "Astro" and are rethinking their strategy to service Baltimore's west side food desert residents. 


\section{Mobile Markets \& Urban Farms}

It was not long before the demand for their fresh food outgrew their farm's capacity to produce. As a result, to meet the demand Real Food Farm now partners with over 17 different farms within 30 miles of the farm throughout a season. A significant source was the Farm Alliance of Baltimore City." All year long on Saturday mornings, you can purchase Real Food Farm produce as part of the Farm Alliance stall at the Waverly $32^{\text {nd }}$ Street Farmers, a pop-up canopy market. This ongoing collaboration helps Real Food Farm fulfill its mission of developing an economically viable, environmentally responsible local agriculture sector. ${ }^{12}$ When asked about the sense of community, mobile market manager Gwen Kokes had this to say, "Some days we don't make any sales because it is the end of the month and customers have spent all their SNAP benefit dollars. But we hang out and chat with the kids and neighbors that know us, know our faces." ${ }^{3}$ In another validation of farmers markets capacity to build community, customers come on market days even though they do not intend to buy anything.

Another mobile market, Veggie Van in Durham County, NC, uses the Community Supported Agriculture (CSA) model to distribute fresh food to people with limited income and access. Customers buy "shares" and receive a weekly delivery of fresh produce either at their place of work or at one of the market stops, such as the public library, where additional produce is also available for sale. ${ }^{14}$ Orders are sold on a sliding scale; people who can afford to spend more often give a few extra dollars to help people with lower incomes afford the produce at a lower cost to them. In 2015, the health department's prenatal clinic began writing prescriptions for fresh food, which expecting mothers can fill at the Veggie Van for a \$2.50 co-pay. The pilot project is paid for with money from a state Public Health Association endowment. Veggie Van makes stops different days of the week for two hours at five locations including recreation centers, health care centers, and the public library. Community Nutrition Partnership (CNP), a local nonprofit, operates Veggie Van and has received funding from the county's Public Health department since $201{ }^{15}$

In a former parking lot adjacent to Durham's Farmers Market (explored in Chapter 3), the nonprofit organization SEEDS established the "Garden of Eatin"" as one of its more recent initiatives to embed community gardens within the city. SEEDS continues to expand their 


\section{Chapter 5}

urban agriculture programs, as they view gardening and growing food as a way to teach "respect for life, for the earth and for each other... [and a way to] promote principles of sustainable agriculture, organic gardening, food security and environmental stewardship." ${ }^{6}$ Through its Community Harvest program SEEDS has partnered with Phoenix House, a transitional program for homeless men to transform barren plots into community gardens where people with limited budgets can rent a plot for as little as \$I per year to grow their own food with assistance from SEED for supplies, tools, and technical support. In alignment with their mission, SEEDS has collaborated with Durham's Latino community since 1999 by co-hosting annual events, such as El Dia Del Nino (Day of the Child) and Dia de los Muertos (Day of the Dead). I firmly believe in the tenets of SEEDS' vision, which I found that numerous organizations and people across our country share. Local markets and allied groups promote these beliefs.

In a change from the mobile markets described above, Chicago's Fresh Moves is a retrofitted out-of-service Chicago Transit Authority bus (see image $5 \cdot 5$ ). With the seats removed, the market goods are completely contained within the bus. Tiers of shelving holding green plastic bins overflowing with fresh produce line both sides of the center aisle. Shoppers enter the front of the bus and make their selections as they move to the rear, where they pay and exit (see image 5.6). Typically, there is not anything set up outside the bus: only when there is a cooking demonstration under a pop-up canopy. It is notable that this market is

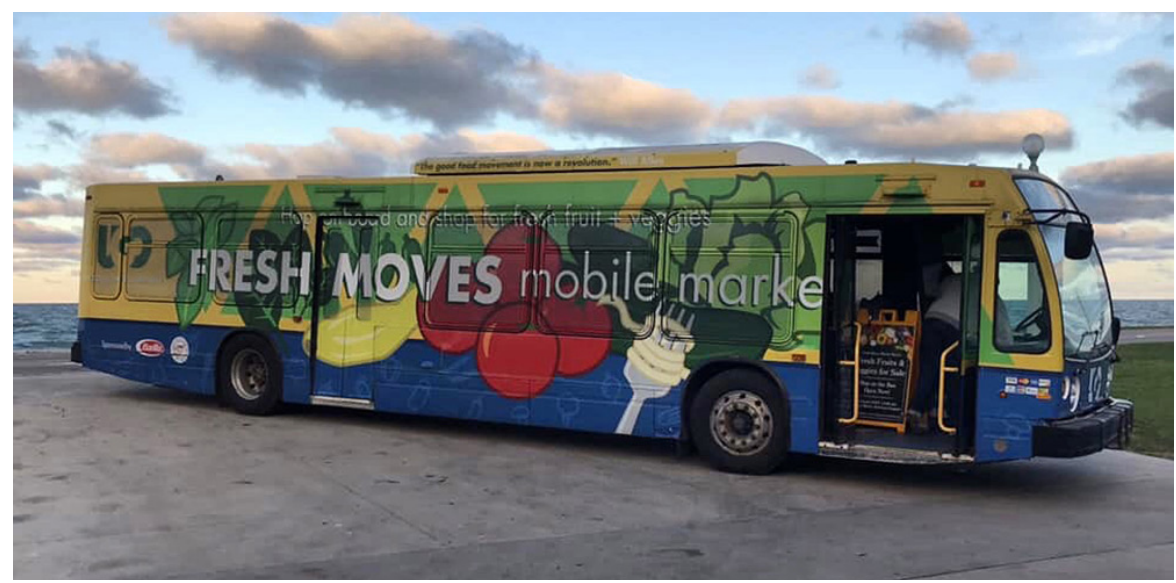

Image 5.5 Fresh Moves Mobile Market converted transit bus. 


\section{Mobile Markets \& Urban Farms}

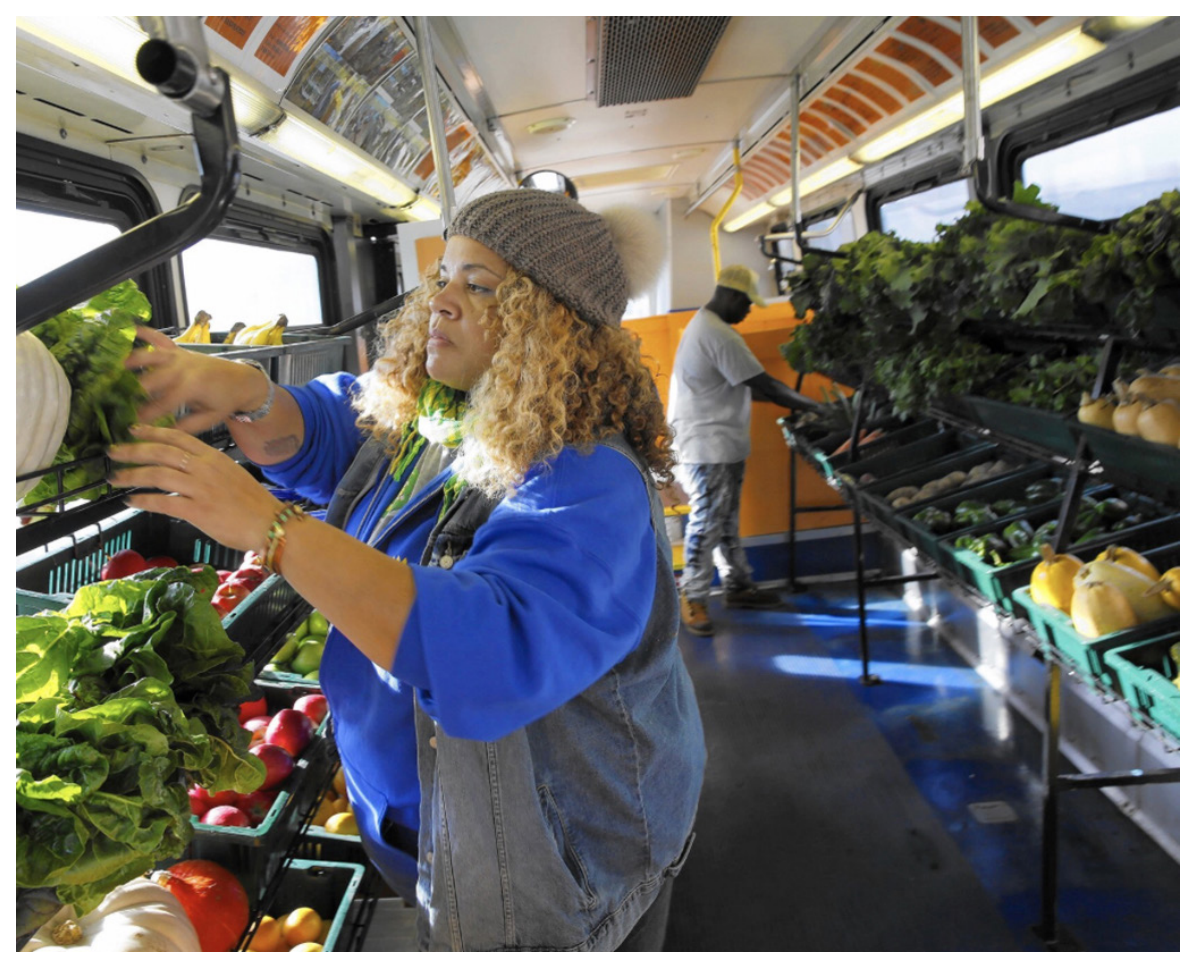

Image 5.6 Fresh Moves Mobile Market interior display.

completely protected from inhospitable weather, and requires no setup time once it reaches one of its weekly thirteen stops in nine of Chicago's south and west neighborhoods- North Lawndale, Austin-Gresham, Garfield Park, Washington Park, Englewood, Roseland, Woodlawn, Grand Boulevard, Fuller Park, and South Shore-which are known for their tough street life and not for fresh, healthy food. Fresh Moves stops at each location for one and a half hours in front of the community's institutions- Mt. Sinai Hospital, Howard Brown Health Center, and Carter G. Woodson Regional Library, to name a few. I found it interesting to learn that at Howard Brown shoppers purchase food that doctors have prescribed to address health issues. ${ }^{17}$

In June 2012, Mayor Emanuel and USDA Secretary Vilsack announced the first round of federal funding for this mobile market, which was initially a program jointly run by Growing Power, Inc. and Food Desert Action, Inc. At the time Mayor Emanuel said, "Public and private investments in programs like Fresh Moves Mobile Market are helping to ensure that all Chicago families have access to affordable, 


\section{Chapter 5}

fresh and healthy food, neighborhood services and the investments in infrastructure, education and public space that create the vital communities of tomorrow." 18

In 2018 Urban Growers Collective (UGC) took over operation of Fresh Moves Mobile Market. Laurell Sims and Erika Allen had founded UGC the previous fall and the mobile market fit their aim to "develop community-based food systems where food is grown, prepared and distributed within their home communities. Working closely with more than 33 community partners, the goal is to build economic opportunity for youth and mitigate food insecurity and limited access to high quality, affordable and nutritionally dense food." ${ }^{\prime 9}$ These partnerships come with established customers in need of easily accessible healthy food as well as ways to get the word out through their organization's marketing and outreach. In the course of a year and a half, UGC has served over IO, OoO customers with over 17 , 000 pounds of produce it grew. ${ }^{20}$

In conversation with Laurell, she said UGC is changing the form of the city through the introduction of urban agriculture, which in turn changes the family dynamic through job training as farmers, which offers the opportunity to change one's individual trajectory. She talked about recently hiring Malcolm as their farm manager. He is now 26 years old, but first worked with UGC as a ro-year-old intern at their Cabrini-Green farm, which is located on a former basketball court. ${ }^{21}$ All of their eight urban farms have transformed empty or underutilized plots, II acres in all, into productive green space that is envisioned as edible landscapes, including flowers. I find this view of landscape as urban infrastructure so fitting in Chicago; Daniel Burnham had envisioned a network of connected public neighborhood parks as the city's emerald necklace, as detailed in the 1909 Chicago Plan that he co-authored with Edward Bennett.

Another relatively new farm in the Cabrini-Green neighborhood, the Chicago Lights Urban Farm, provides healthy food and economic empowerment for its poor residents on land that was previously an abandoned basketball court. The Fourth Presbyterian Church's Chicago Lights Academic Success in Schools provided the initial leadership, which empowered "youth and community residents in the Cabrini-Green neighborhood to have increased economic opportunities through access to organic produce, nutritional education, work force training, and microenterprise development." ${ }_{22}$ 


\section{Mobile Markets \& Urban Farms}

They planted a community garden in 2003 that transitioned into an urban farm in 20I0, when Chicago Lights partnered with "Growing Power-a nonprofit organization empowering communities by helping to provide equal access to healthy, high quality, safe, and affordable food. Garden plots are available to neighborhood residents who live within a five-block radius of the farm. ${ }^{23}$ Today the farm cultivates 25 types of crops on 30,000 square feet. The farm layout was the outcome of a charrette that included architects, youth participants, community stakeholders and the organization's advisory board. The vision with a plan for the farm's future was established within the day. ${ }^{24}$ As a testament to this farm's accomplishment, supporters who live beyond the five-block radius volunteer their time in various capacities to ensure its ongoing success: another example of the ways in which a community interested in changing our food system appears to have no boundaries.

By early 2015 Chicago Lights Urban Farm had expanded its outreach in the community in three ways: through the opening of its farm stand, located at $444 \mathrm{~W}$. Chicago Avenue; by offering subscriptions to its CSA Salad Shares; and through regular deliveries using their mobile market-GoodFood Mobile. The latter is an Urban Lights microenterprise that distributes fresh farm produce on Saturdays to neighboring residents who have ordered it online. In addition to these programs Chicago Lights Urban Farm is ensuring its sustainability through partnerships with nearby charter school Chicago Quest and higher education institutions Kendall College and Roosevelt University. ${ }^{25}$

Probably the most unusual urban farm in Chicago is the Rooftop Garden. At the opening celebration, Sophia Siskel, president and CEO of Chicago Botanic Garden, offered this summation: "This rooftop garden will have positive ripple effects as it expands our local agriculture production capabilities, saves on harmful gas emissions by eliminating the need to transport some of our food needs, creates additional hands-on training and job opportunities for our Windy City Harvest students, and serves as a local source of fresh produce to a major convention center catering provider." ${ }^{26}$ An unprecedented partnership joins Savor, the Chicago catering company for the McCormick Place West convention center, with the city's Botanic Garden's Windy City Harvest (WCH) program, which is "a social enterprise that provides a nine-month certificate training program and internship in sustainable 


\section{Chapter 5}

horticulture and urban agriculture. The program is offered in partnership with Richard J. Daley/Arturo Velasquez Institute and accredited by the Illinois Community College Board." ${ }^{27}$ WCH students designed and planted Rooftop Garden, which includes 20,000 square feet of vegetables and herbs. It yields 8,000 pounds of farm-fresh plenty and is home to 20,000 honeybees that yield 50 pounds of honey annually. This stellar example of the changing origins of our food supply, and thereby distribution and consumption, translates into greater food security and sustainability of healthy food. This unconventional location for a farm pushes us to rethink the development of our cities.

In neighboring Cleveland, Ohio, sits City Farm, a six-acre incubator farm on publicly owned land located a mile from downtown. It is one part of four separate but connected initiatives of the Ohio City Fresh Food Collaborative that aims "to solidify Ohio City as the hub of Cleveland's complete regional food system." ${ }^{28}$ I toured the farm in September 2012 and was struck by the ingenuity of converting the underutilized grassy expanse, which required resource-draining maintenance (lawncare), into income-generating food production. I was further amazed by the collaboration among seemingly incongruent entities-Cuyahoga Metropolitan Housing Authority (CMHA), the Great Lakes Brewing Company (GLBC), and Refugee Response (RR) - who had come together to bring the project to fruition. As I learned more about each group's role and stake in the enterprise, I saw an amalgamated community that complimented each other's needs and resources based on shared principles about how we should live and what we should eat. CMHA supplied the land and in turn was provided access to discounted, healthy food for its on-site residents; the GLBC restaurant provided business acumen and initial funding, and gained nearby access to high-quality food for its chefs, and ultimately its diners; and RR resettled refugees who gained employment and on-the-job training through working on the farm. Two other groups-Central Roots and Cleveland Crops-also cultivate land at Ohio City Farm, which gives them access to low-cost land, shared facilities, and technical assistance. The expectation is that these farmers will "run economically viable businesses and provide financial information on their operations" for the benefit of future like-minded urban farmers. ${ }^{29}$ Central Roots also operates a farm stand on the premises, which provides them with direct sales in addition to opportunities to educate 


\section{Mobile Markets \& Urban Farms}

customers about the full extent of urban agricultural operations at Ohio City Farm. The interconnected purposes and benefits of these groups appear to provide sustainability for each enterprise while strengthening the solidarity of the neighborhood.

Downstate in Cincinnati, the Corporation for Findlay Market (the managing entity of the heritage building discussed in Chapter 2) collaborates with those of the Civic Garden Center, which has advocated for a tradition of agriculture within the city's limits for over two decades since 1994. The Civic Garden Center has a cornerstone program, Neighborhood Gardens, which engages and successfully benefits twenty-three communities through the annual harvest of forty-seven gardens. The Corporation for Findlay Market established its CHEF program (Cultivating a Healthy Environment for Farmers) upon receipt of a 2009 USDA grant, which garnered nearly $\$ 60,000$ "to recruit, train and provide start-up resources for new farmers to grow vegetables on vacant urban lots and sell at Findlay Market." ${ }^{\circ}$ In 20I0-20II, Findlay Market Urban Farms collaborated with the Civic Garden Center to establish Eco Garden, which provides "an experiential learning opportunity for inner-city youth to cultivate self-reliance, job skills and an entrepreneurial aptitude by cultivating a market garden for direct sales at Findlay Market." ${ }^{31}$ By the end of 2013, Findlay Market Farms was working with numerous partners and had "more than 25 apprentice farmers [and was] growing on four sites (two in Over-the-Rhine, and one each in Hartwell and Westwood)." $3^{2}$ In 2013, Findlay Market further expanded its outreach into three neighborhoods-East Price Hill, Walnut Hills, and Westwood-by bringing the market to residents via farm stands in collaboration with Roberts Academy, the Walnut Hill Redevelopment Foundation, and St. James Episcopal Church, respectively. Roberts Academy is a public school that was "trying to overcome cultural, language and economic barriers to teach parents how to use their food assistance (SNAP) benefits to purchase fresh healthy foods rather than convenience foods." Heather Wigle, a volunteer at Roberts Academy, sums up the farm stand's success as going beyond solely eating healthy food. She says, "This is about more than peanut butter, popcorn and produce. It is about building community and bridging cultural barriers. People see bridging (cultural gaps) as a big thing, but really it's just that we need to get to know our neighbors better and build community." ${ }^{33}$ 


\section{Chapter 5}

In tandem with mobile markets servicing urban food deserts, the exponential growth in the number of farmers markets in recent decades has also helped ameliorate a growing environmental issue: preserving farmland, which preserves rural livelihoods as well. The Farmers Market Coalition, a nonprofit organization that tracks the relationship between opportunities farmer markets offer for small farmers and the amount of farmland in production, found that in the Seattle region a total of seven farmers markets support 9,49I acres of farmland in diversified production. ${ }^{34}$ They also found that even a small farmers market has a significant impact: Georgia's Lilburn Farmers Market gives ten farmers an opportunity to grow produce on 500 acres of farmland. 35 The rural livelihood not only increases as the number of farmers markets rises but also as more farmers markets are open year-round. The Coalition tracked farmers markets operating during the winter months between $201 \mathrm{I}$ and 2012 and recorded a 52 percent growth, for a total of I, 864 . This number continues to increase substantially each year. In this way, they contend, "farmers markets provide one of the only low-barrier entry points for new farmers, allowing them to start small as they learn and test the market." 36

This symbiotic rapport between farmers markets, farmland, and livelihood expands the sense of community exponentially. And while this extends beyond the focus of exploring farmers markets as an architecture of place-making, it illustrates the inextricable interwoven complexity of farmers markets as community gathering places within the urban/rural framework. The numerous farmers markets across our country form a constellation that sustains us with more than food. 


\section{CONCLUSION}

\section{A SENSE OF PLACE, A SENSE OF TIME}

A sense of place is something that we ourselves create in the course of time. It is the result of habit or custom.

- J. B. Jackson ${ }^{1}$

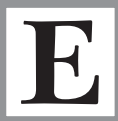

Every farmers market is unique in its own way. This is what I tell people when they ask me what the key is to starting a new market in their own communities. There is, in fact, no single key because every community has its own distinctive character, and for this reason I am convinced that farmers markets are most successful when they grow organically out of the efforts and initiative of the citizens of the community. This is what the Project for Public Spaces (PPS) means by the idea of "placemaking." As PPS explains on its web site, effective placemaking is a collaborative process that engages people and inspires them to utilize the unique assets of their community in building, or renovating, public spaces. ${ }^{2}$

Recognizing how difficult it is to create successful public spaces, PPS published a book entitled How to Turn a Place Around, in which it identified eleven principles for successful placemaking. These are:

I) The community is the expert,

2) Create a place, not a design,

3) Look for partners,

4) You can see a lot just by observing, 


\section{Conclusion}

5) Have a vision,

6) Start with the petunias: Lighter, quicker, cheaper,

7) Triangulate,

8) They always say "It can't be done",

9) Form supports function,

Io) Money is not the issue, and

II) You are never finished. ${ }^{3}$

I support these principles. And yet, as I've tried to show in this book, it is also possible to look at farmers markets from the perspective of architecture and design. I have identified three traditional types of markets-heritage building, open-air pavilion, and pop-up canopy-plus a fourth one in the making-the mobile market. It is no mistake that farmers markets across the country tend to fall into one of these categories. Not only do the types reflect a long history of public markets in America, they embody certain elements of architecture and urban design that engage our human bodies and allow us to make sense of our experiences and build collective memories. Ultimately, these elements boil down to the eight scales of interaction and interface I identified in Chapter I-hand, container, person, individual vendor stall, group of stalls, street, block, and market's situation within neighborhood or district.

Taking it a step further, effective markets incorporate physical architectural elements (columns, thresholds, doorways, floors, roofs, signage, seating, etc.) within a specific urban setting (surrounding buildings, plazas, parks, sidewalks, parking, transit access, topography, etc.) that result in a successful community gathering place. But it is not enough for these elements simply to exist; it is how these elements come together in a particular location that gives each market its own architecture of place. In every case, the eight scales of interaction and interface can be seen in the following:

- Configuration of stalls

- Human-scale display of goods

- Places for people to sit, eat, chat or linger

- Individualized vendor signage

- Protection from rain and sunshine

- Location, visibility and accessibility 


\section{A Sense of Place, A Sense of Time}

The configuration of stalls allows smooth flow through the market and quick viewing of what is available. Individualized vendor signage enables customers to identify new vendors as well as verify regular ones. Human-scale display of goods permits shoppers to select their purchases with ease. Protection from the rain and sun is rather obvious in its importance. Places for people to sit, eat, chat, or linger is crucial to building community and thus placemaking. Likewise, location, visibility, and accessibility (parking at the very least) allow shopping at the farmers market to become ritual.

In addition to these architectural factors, successful farmers markets often have the following:

- Variety of vendors

- Area for local musicians to perform

- Adjacent public open space

- Acceptance of SNAP benefits

- Access to public transit

- Annual special events

Seemingly minor design features can also play a role in turning a simple landscape into a place where people want to gather. For instance, at the Blacksburg Farmers Market curvilinear benches and cobblestone pavers provide variation in an otherwise unremarkable setting. On the convex portion of the curve, the serpentine benches allow strangers to sit adjacent to one another without feeling crowded, while on the concave portion, people can face each other in conversation. They also serve as a barrier akin to a fence along one of the adjacent streets. The cobblestone pavers under the structure and in the alley and parking area provide an urban floor akin to a plaza, such that when cars are not present one does not realize it is a parking lot. And finally, a half-dozen leafy green trees on the grassy area of the park define a space where friends can huddle in conversation, children can dance to music, and families can sit on blankets and eat ice cream. There's even enough room for a 20 -foot by 2o-foot tent for annual tomato and apple tasting events.

It is difficult to measure the impact that the architecture and design of a farmers market can have on the community. Still, even in a small town like Blacksburg the indicators are positive. Since the renovation of the Blacksburg Farmers Market pavilion and park, vendor revenues have doubled, from $\$ 600,000$ in 2009 to $\$$ I.2 million in 20I8. This 


\section{Conclusion}

translates into more money kept in the local economy as well as more jobs on local farms and at farmers markets. To keep up with customer demand on market days and to avoid long waiting lines, some vendors have hired college students to assist at their stalls and, in some cases, to even intern on vendors' farms. More people stay longer at the market, listening to local musicians and chatting as children play in the park. Also, new partnerships have formed, with local food pantries supplementing canned and dry goods with fresh healthy produce. On most market days the New River Valley Master Gardeners Association sets up a stall with their banner "Share the Spare" and collects fresh food donations. After the market ends, the NRVMGA delivers excess produce to Giving Tree Food Pantry, the Interfaith Food Pantry, and Spiritual Roots Community Food Bank.

The future looks bright for the Blacksburg Farmers Market. In late 2018 town leadership completed a Downtown Strategy Plan that includes the potential of building an indoor market hall as part of its vision. If enacted, a new market building will be constructed in the coming decade adjacent to the existing pavilion. This would be a major step forward in revisioning downtown Blacksburg with the farmers market at its core.

Cincinnati's Findlay Market offers one more example of the far-reaching impact that a market can have on a community. Since City Council adopted the Over-the-Rhine Comprehensive Plan in June 2002, the market has expanded from a single building into a multiple-block district from Findlay to Liberty streets and Central to Vine streets (see image 6.I). The Corporation for Findlay Market has taken a leadership role as the "preferred developer" for 39 city-owned buildings and acquired several additional properties to accelerate development in the blocks surrounding the market building. The plan identifies Findlay Market as a key development asset and envisions Findlay Market as "a food and flowers district that is eventually seen as a daily market for residents of Over-the-Rhine and outlying neighborhoods with additional restaurants and housing." 4 The newest development, Market Square, was completed in 2018 by local developer Model Properties, a leader in community revitalization for 38 years. This project includes the complete renovation of 23 apartments, Io for-sale residential condominiums, and 47,576 square feet of retail and office space. ${ }^{5}$ 


\section{A Sense of Place, A Sense of Time}

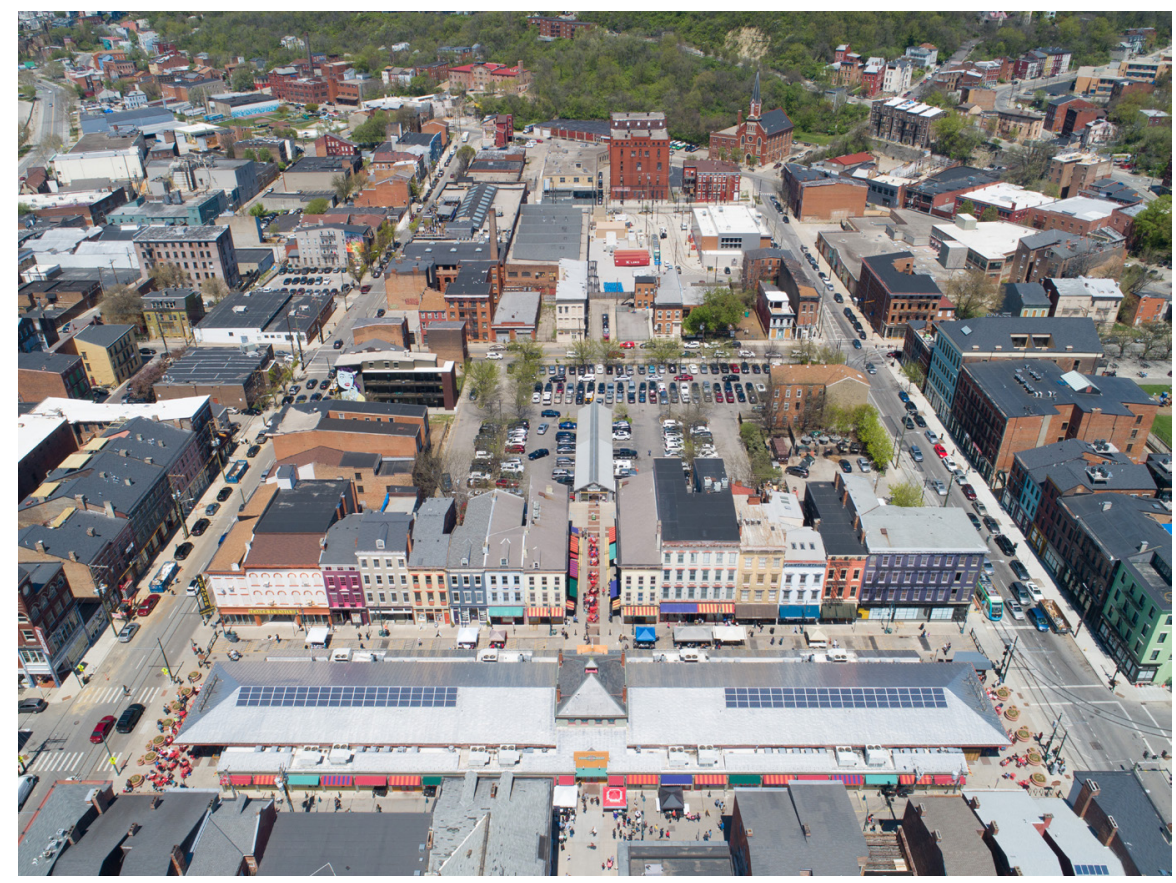

Image 6.1 Aerial view of Findlay Market District.

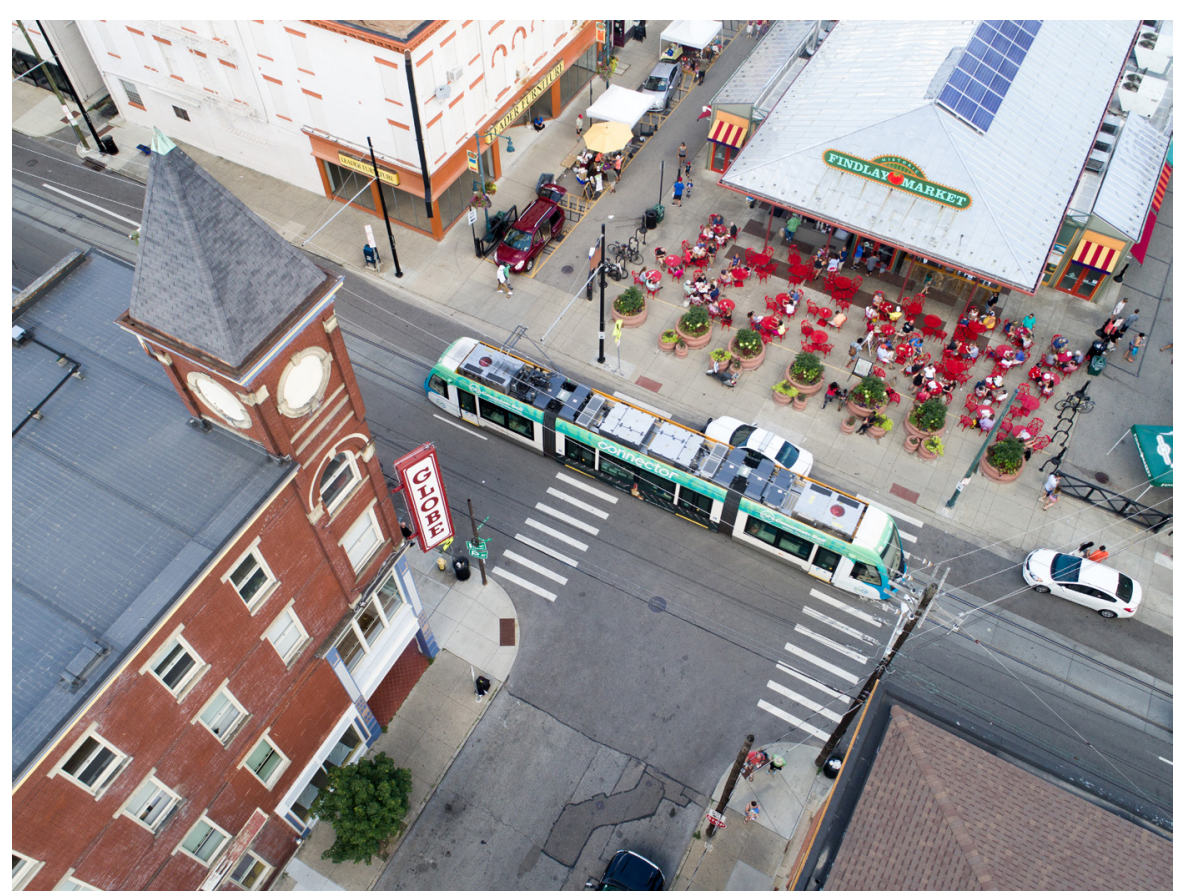

Image 6.2 Cincinnati Bell Connector transit stop at Findlay Market. 


\section{Conclusion}

In addition to redevelopment, the opening in 2016 of the Cincinnati Bell Connector was significant to the prosperity of the market district. It is a 3.6-mile streetcar loop with eighteen stops connecting Cincinnati's riverfront, Downtown, and Over-the Rhine neighborhoods. This public amenity has improved access for people working in downtown to easily get to Findlay Market for lunch or shopping during their workday. Like DC's Eastern Market, Findlay Market now has a transit stop named for it (see image 6.2).

As I was finishing up the writing of this book, the Blacksburg Farmers Market was in full swing for yet another season. One Saturday morning I visited the market, taking time to sit on one of the serpentine benches and do a bit of people-watching. Vendors were busy selling fresh flowers and produce. Colorful banners with farm names were strung between columns. A child leaned on a column as she stood in line for homemade ice cream. University students were ever-present as spring exams had yet to begin. Blacksburg's farmers market is small, especially compared to other market cities I've visited, such as Cincinnati and Washington, DC. Still, the experience of sitting in the sun on a busy market Saturday feels pretty much universal. This no doubt explains, at least in part, why I go out of my way to find a farmers market whenever I am visiting another town or city. I both know and don't know what I will find. The experience is both new and familiar. How could it be any other way.? 


\section{NOTES}

\section{INTRODUCTION}

1 S. M. Sener, Esq., "Lancaster Townstead," Lancaster County Historical Society, Papers, V. 5: 121 and accessed City of Lancaster website December 14, 2018, http:// cityoflancasterpa.com/business/lancaster-previous-decades

2 Tim Appelo, "Rescue in Seattle," Historic Preservation (October 1985): 34-39.

3 Valerie Jablow with Bill Horne, "Farmers' markets," Smithsonian Magazine 30, no. 3 (June 1999): 120.

4 Catherine Bailey and Sarah Kuck, "Go Local," YES! (Winter 2007).

\section{CHAPTER 1}

1 Ellen Stewart, interview by Kathryn Albright, August 27, 2011, Blacksburg, VA.

2 Pomegranate Center website, accessed May 22, 2012, http://www. pomegranatecenter.org.

3 Robert Sommer, John Herrick, and Ted R. Sommer, "The Behavioral Ecology of Supermarkets and Farmers' Markets," Journal of Environmental Psychology 1, no. 1 (March 1981): 13-19.

4 Brian Halweil, Eat Here: Reclaiming Homegrown Pleasures in a Global Supermarket (New York: W.W. Norton \& Company, 2004), 123.

5 Lucy Lippard, The Lure of the Local: Senses of Place in a Multicentered Society (New York: The New Press, 1997), 32.

6 John Brinckerhoff “J.B." Jackson, A Sense of Place, a Sense of Time (New Haven: Yale University Press, 1996), 152.

7 Joan S. Dentler, "Farmers' Markets Serve as Community Gathering Places," Belmont Patch, August 15, 2011, http://belmont-ca.patch.com/groups/business-news/p/ farmers-markets-serve-as-community-gathering-places.

8 Halweil, Eat Here, 100.

9 Leon Battista Alberti, On the Art of Building in Ten Books, trans. and ed. Joseph Rykwert, Robert Tavernor, and Neil Leach (Cambridge, MA: MIT Press, 1988), 95. 


\section{Notes for Chapter 2}

10 Christian Norberg-Shultz, Genius Loci: Towards a Phenomenology of Architecture (New York: Rizzoli,1979), 5.

11 Sommer, "The Behavioral Ecology," 13-19.

12 Michael Pollan, National Public Radio, August 21, 2009.

13 Mark Francis and Lucas Griffith, "The Meaning and Design of Farmers' Markets as Public Space: An Issue-Based Case Study," Landscape Journal 30, no. 2 (2011): 261-269.

14 Helen Tangires, Public Markets and Civic Culture in Nineteenth Century America (Baltimore: The John Hopkins University Press, 2003), 31.

15 Nancy McKeon, “Peak Season," Washington Post, August 8, 2006.

16 Halweil, Eat Here, 162.

17 Francis and Griffith, "The Meaning and Design," 263.

18 Wholesome Wave website, accessed December 28, 2018, https://www. wholesomewave.org/

19 “Executive Summary,” 2009-2012 Outcomes and Trends, Wholesome Wave, 3.

\section{CHAPTER 2}

1 As Helen Tangeris points out, "Local business and nearby property owners depended on their [public markets'] success as did country producers and street vendors." Public Markets and Civic Culture in Nineteenth Century America (Baltimore: The Johns Hopkins University Press, 2003), 26.

2 Bart Barnes, "A local life: Chris Calomiris, 86, the face of D.C.'s Eastern Market," Washington Post, February 12, 2011.

3 Ibid.

4 "Re-building the Future of Eastern Market" (tour brochure, Eastern Market, June 2009).

5 "Red Architect Returns to Washington" (press release, Goethe-Institut, Washington, DC, September 2005).

6 Stuart Smith, interview by Kathryn Albright, February 17, 2007.

7 "Interview with Baird Smith," by Ev Barnes, The Ruth Ann Overbeck Capitol Hill History Project, April 30, 2009, http://www.capitolhillhistory.org/interviews/2009/ smith_baird.pdf.

8 Kent Boese, "Then and Now: The O Street Market," Greater Greater Washington, June 24, 2009, http://greatergreaterwashington.org/post/2697/then-and-now-the-ostreet-market/.

9 "Interview with Baird Smith," by Ev Barnes.

10 Stuart Smith, interview by Kathryn Albright.

11 Allison Klein, Keith L. Alexander, and Michelle Boorstein, "2 Fires Ravage East- 


\section{Notes for Chapter 3}

ern Market, Georgetown Library in 12 Hours," Washington Post, May 1, 2007.

12 Ibid.

13 "Re-building the Future of Eastern Market."

14 For a list of the major awards, see Quinn Evans Architects webpage, accessed January 11, 2016, http://www.quinnevans.com/work/eastern-market/.

15 Cliff Radel, "City needs to revive spirit of 1853," Cincinnati Enquirer, April 20, 2003, http://enquirer.com/editions/2003/04/20/loc_150years20.html.

16 “A Brief History of Cincinnati's Findlay Market," on Cincinnati's Findlay Market webpage, accessed September 19, 2011, http://www.findlaymarket.org/markethistory/.

17 “Market District Development," on Cincinnati’s Findlay Market webpage, http:// www.findlaymarket.org/district-development.

18 "Our Story," on Cincinnati's Findlay Market webpage, accessed September 19, 2011, http://www.findlaymarket.org/story/ and accessed November 17, 2015, http:// www.findlaymarket.org/economic-development/.

19 Zane L. Miller and Edward Bruce Tucker, Changing Plans for America's Inner Cities: Cincinnati's Over-The-Rhine and Twentieth-Century Urbanism (Columbus, OH: Ohio State University Press, 1998).

20 Findlay Kitchen website, accessed December 28, 2018, https://findlaykitchen.org/.

21 Glaserworks website, accessed December 28, 2018, http://glaserworks.com/about/ awards/.

\section{CHAPTER 3}

1 Helen Tangires, Public Markets (New York: W. W. Norton \& Company, 2008), 159.

2 Tamera McNaughton, phone interview by Kathryn Albright, January 27, 2015.

3 Tamera McNaughton, email to Kathryn Albright, February 2, 2015.

4 Dwayne McIntrye, interview by Kathryn Albright, July 28, 2012.

5 Ibid.

6 David Mehl, interview by Kathryn Albright, July 28, 2012.

7 Hannah Mehl, interview by Kathryn Albright, July 28, 2012.

8 Al Bradley, phone interview by Kathryn Albright, September 26, 2012.

9 Garrett Jackson, email to Kathryn Albright, July 29, 2012.

10 Ed Morgan, email to Kathryn Albright, September 2, 2012.

11 Al Bradley, phone interview.

12 “Park History," Durham Central Park website, accessed November 23, 2012, http:// durhamcentralpark.org/about/history/.

13 Ibid. 


\section{Notes for Chapter 3}

14 Elizabeth Gibbs, phone interview by Kathryn Albright, November 27, 2012.

15 "The History of SEEDS," South Eastern Efforts Developing Sustainable Spaces, Inc. website, accessed December 3, 2013, http://www.seedsnc.org/history/.

16 Mary Yost, phone interview by Kathryn Albright, 05.24.19.

17 Ibid.

18 "Park Story: SEEDS' Garden of Eatin'," Durham Central Park Blog, April 24, 2013, http://durhamcentralpark.org/park-story-garden-of-eatin/.

19 Lucy Lippard, The Lure of the Local: Senses of Place in a Multicentered Society (New York: The New Press, 1997), 7.

20 Stuart White, quoted in Brad Herring, "A Farming Way of Life - Bluebird Meadows," video on Vimeo.com, accessed April 1, 2014, http://vimeo.com/25665217.

21 Ibid.

22 Alice White, quoted in Brad Herring, "A Farming Way of Life - Bluebird Meadows," video on Vimeo.com, accessed April 1, 2014, http://vimeo.com/25665217.

23 “The Farm,” Bluebird Meadows Farm website, accessed December 3, 2013, http:// www.bluebirdmeadowsnc.com/farm/farm_main.htm.

24 Alice White, quoted in Brad Herring.

25 Ibid.

26 Erin Kauffman, interview by Kathryn Albright, November 17, 2012.

27 Ellen Cassilly, interview by Kathryn Albright, November 17, 2012.

28 Tim McAller, email to Kathryn Albright, June 18, 2013.

29 "Four Leaf Farm," Durham Farmers' Market website, accessed June 18, 2013, http://durhamfarmersmarket.com/vendorprofile.html?DFMv=12.

30 Tim McAller, email to Kathryn Albright, June 18, 2013.

31 Four Leaf Farm website homepage, accessed June 18, 2013, http://www. fourleaffarm.org.

32 Tim McAller, email.

33 "Recognition," on Ellen Cassilly Architect webpage, accessed January 14, 2016, http://www.ellencassillyarchitect.com/recognition-2/, and "Lists," on The Daily Meal webpage, accessed on January 11, 2016, http://www.thedailymeal.com/101best-farmers-markets-in-america/.

34 Keith and Marie Zawistowski, interview by Kathryn Albright, January 30, 2014.

35 "Covington Farmers Market," design/buildLAB website, accessed April 1, 2014, http://www.designbuildlab.org/gallery-2/covingtonfarmersmarket/.

36 "Welcome to the Alleghany Highlands," Alleghany Highlands Chamber of Commerce and Tourism website, accessed June 13, 2013, http://www.ahchamber.com/ main/index.php.

37 Teresa Hammond, interview by Kathryn Albright, June 14, 2013.

38 Jacob Wright, interview by Kathryn Albright, June 25, 2013. 


\section{Notes for Chapter 4}

39 "About the Program," design/buildLAB website, accessed June 13, 2013, http:// www.designbuildlab.org/about/.

40 “About Us," Covington Farmers Market website, accessed May 23, 2019, http:// www.covingtonfarmersmarket.com/about-us.html.

41 Ibid.

42 Martha Nicholson, interview by Kathryn Albright, June 14, 2013.

43 Patsy McKinney, interview by Kathryn Albright, November 18, 2013.

44 Keith and Marie Zawistowski, interview.

45 "Covington Farmers Market," design/buildLAB website.

46 "Covington Farmers Market / design/buildLab, https://www.archdaily.com/166527/ covington-farmers-market-designbuildlab/, September 7, 2011.

47 Josie Showalter, interview by Kathryn Albright, September 23, 2013.

48 Ibid.

49 "About Historic Downtown Farmers Market," Hot Springs Farmers \& Artisans Market website, accessed July 23, 2012, http://www.hotspringsfarmersmarket.com/ About-Us.html.

\section{CHAPTER 4}

1 Anna Blessing, Locally Grown: Portraits of Artisanal Farms from America's Heartland (Evanston, IL: Midway Books, 2012).

2 "by the White House, DC," video on FRESHFARM website's White House market location page, accessed April 1, 2014, http://freshfarmmarkets.org/farmers markets/markets/white_house.php.

3 “Alexandria City Hall," Wikipedia, last modified January 14, 2014, http://en.wikipedia.org/wiki/Alexandria_City_Hall.

4 Ibid.

5 Patricia Palermino, phone interview by Kathryn Albright, November 19, 2013.

6 Ibid.

7 Ibid.

8 "Old Town Farmers' Market Regulations," the City of Alexandria's website, last modified April 25, 2014, http://www.alexandriava.gov/generalservices/info/default .aspx?id=5464.

9 Ibid.

10 Sara Rhodes, email to Kathryn Albright, December 29, 2015.

11 Barbara Maxwell, "Alexandria farmers' market opens this week," Alexandria City Buzz Examiner, May 3, 2010, http://www.examiner.com/article/alexandria-farmersmarkets-open-this-week.

12 Tom Calhoun, phone interview by Kathryn Albright, January 4, 2014. 


\section{Notes for Chapter 4}

13 Ibid.

14 Ibid.

15 Calhoun's Country Hams website, accessed January 5, 2014, http://www. calhounhams.com.

16 Brad Jones, "People Who Give a Shit': Yi Wah, Caitlin and Number 1 Sons," Artisan \& Apprentice: A Food Anthology, June 7, 2013, http://www. artisanandapprentice.com/number1sons/.

17 Ibid.

18 Caitlin Roberts, email to Kathryn Albright, October 17, 2013.

19 Caitlin Roberts, phone interview by Kathryn Albright, May 31, 2019.

20 Tom Calhoun, phone interview.

21 “Old Town Farmers' Market Regulations," the City of Alexandria's website.

22 Ibid.

23 "Charlottesville City Market," CvillePedia, last modified February 17, 2014, http:// www.cvillepedia.org/mediawiki/index.php/Charlottesville_City_Market\#cite_ref-1.

24 "Charlottesville City Market 2011 survey," University of Virginia Jefferson Public Citizens.

25 Chris Engel, memo to the Office of Economic Development, City of Charlottesville website, accessed October 18, 2013.

26 Lucy Lamm, phone interview by Kathryn Albright, October 18, 2013.

27 Gail Hobbs-Page, phone interview by Kathryn Albright, October 14, 2013.

28 Ibid.

29 “About Us," Radical Roots Farm website, accessed September 16, 2013, http://radicalrootsfarm.com/about-us/.

30 Lee Sturgis O’Neil, phone interview by Kathryn Albright, October 21, 2013.

31 "A Lot to Love at the Charlottesville City Market," City Market District Alliance website, accessed October 21, 2013, http://kmkildea.wordpress.com/what-cani-do/.

32 "City Market Permanent Home," Market Central, City Market's official website, accessed October 20, 2013, http://marketcentralonline.org/about/city-marketpermanent-home/.

33 Ibid.

34 Charlottesville City Market 2011 survey.

35 Caromont Farm Brochure, September 14, 2014.

36 Gail Hobbs-Page, phone interview.

37 Sean Tubbs, "Council to seek proposals to redevelop City Market site," Charlottesville Tomorrow, October 22, 2013, http://www.cvilletomorrow.org/news/ article/16309-city-market-proposals/.

38 City of Charlottesville website, accessed December 29, 2015, http://www. charlottesville.org 


\section{Notes for Chapter 5}

39 Lucy Lamm, phone interview by Kathryn Albright, May 14, 2019.

40 Lucy Lippard, The Lure of the Local: Senses of Place in a Multicentered Society (New York: The New Press, 1997), 7.

41 "Customer comments about the Staunton/Augusta Farmers' Market," Staunton/ Augusta Farmers' Market official website, accessed August 18, 2013, http://www .safarmersmarket.com/customer comments.htm.

42 Bill Frazier, phone interview by Kathryn Albright, November 15, 2013.

43 Ibid.

44 "About Historic Staunton Foundation," Historic Staunton Foundation website, accessed October 15, 2013, http://www.historicstaunton.org/About\%20 HSF/abouthsf.htm; and "District Map," City of Staunton, Virginia website, accessed October 15, 2013, http://www.staunton.va.us/directory/departments-h-z/ planning-inspections/historic-districts/map.

45 Susan Spano and Aviva Shen, "The 20 Best Small Towns in America of 2012," Smithsonian, May 1, 2013, http://www.smithsonianmag.com/travel/the-20-bestsmall-towns-in-america-of-2012.

46 "Great Places in America," American Planning Association, Planning magazine, December 2016, https://www.planning.org/planning/2016/dec/.

47 Bill Frazier, phone interview.

48 Ibid.

49 Amanda Rhodes, email to Kathryn Albright, September 19, 2013.

50 Barbara Womack, interview with Kathryn Albright, September 7, 2013.

51 Tom Womack, interview with Kathryn Albright, September 7, 2013.

52 Peg Davis, email to Kathryn Albright, October 1, 2013.

53 Ibid.

54 Susan Randall, email to Kathryn Albright, September 19, 2013.

55 Christine Huger, email to Kathryn Albright, September 23, 2013.

56 Sophie Cantell Lambert, email to Kathryn Albright, May 24, 2019.

57 Susan Randall, email.

58 Peg Davis, email.

59 “History of Staunton's 'Model Market'," Staunton/Augusta Farmers' Market official website, accessed September 2, 2013, http://safarmersmarket.com/history.htm.

\section{CHAPTER 5}

1 “About Us," Fresh Truck website, accessed October 4, 2015, http://www.freshtruck .org/about-us/.

2 Erinn Figg, "Green Machine rolls out fresh produce in South Memphis," online news by High Ground, posted March 12, 2014, http://www.highgroundnews.com/ innovationnews/greenmachine031214.aspx. 


\section{Notes for Chapter 5}

3 “Executive Summary,” Arcadia Annual Report 2017, 3

4 “Executive Summary," Arcadia Mobile Market 2014 Report, 7.

5 Pamela Hess, email to Kathryn Clarke Albright, May 23, 2019.

6 "Mobile Market," Arcadia website accessed May 25, 2019, http://arcadiafood.org/ programs/mobile-market/.

7 “About Us," Real Food Farm website accessed May 24, 2019, http://realfoodfarm. civicworks.com/about-us/.

8 Ibid.

9 “Measuring Impact, A Guide to Mobile Farmer's Markets Fall 2016," Real Food Farm website accessed May 24, 2019, http://realfoodfarm.civicworks.com/wpcontent/uploads/2017/01/How-to-MFM.pdf, pg. 10.

10 "Vehicle Options, A Guide to Mobile Farmer's Markets Fall 2016," Real Food Farm website accessed May 24, 2019, http://realfoodfarm.civicworks.com/wp-content/uploads/2017/01/How-to-MFM.pdf, pg. 6.

11 Gwen Kokes, phone conversation with Kathryn Clarke Albright, June 10, 2019.

12 "Farmers Markets," accessed web site, May 24, 2019, http://realfoodfarm. civicworks.com/get-food/farmers-markets/.

13 Gwen Kokes, phone conversation with Kathryn Clarke Albright, June 10, 2019.

14 "Oases on wheel reaching Durham's 'food deserts'," The News \& Observer, February $12,2015$.

15 "Veggie Van Expanding to Three New Sites," Durham County Department of Public Health, press release, January 15, 2015.

16 “Mission, Vision, \& Values," SEEDS website, accessed January 18, 2014, http:// www.seedsnc.org/mission-vision-values/.

17 "Fresh Moves Mobile Market," accessed web site June 7, 2019, https:// urbangrowerscollective.org/fresh-moves-mobile-market/.

18 Ibid.

19 “About Us," accessed web site June 7, 2019, https://urbangrowerscollective.org/ about-us/.

20 Ibid.

21 Laurell Sims, phone conversation with Kathryn Clarke Albright, June 7, 2019.

22 "General Description," Chicago Lights Urban Farm website, accessed January 7, 2014, http://www.chicagolights.org/.

23 Ibid.

24 Carleigh Rinefierd, email to Kathryn Clarke Albright, June 6, 2019.

25 "Our Partners," Chicago Lights website, accessed September 25, 2015, http:// www.chicagolights.org/our-programs/urban-farm/our-partners/.

26 Ibid.

27 “Windy City Harvest," Chicago Botanic Garden website, accessed January 1, 2014, www.chicagobotanic.org/windycityharvest. 


\section{Notes for Conclusion}

28 “An Urban Food System," Ohio City Fresh Food Collaborative website, accessed December 31, 2013, http://ohiocityfarm.wordpress.com.

29 Ibid.

30 "Findlay Market Chef Program," Findlay Market website, accessed December 23, 2013, http://www.findlaymarket.org/findlay-market-farms/.

31 "Findlay Market Farms," Findlay Market website, accessed December 23, 2013, http://www.findlaymarket.org/findlay-market-farms/.

32 Ibid.

33 Julie Murray, "Findlay Market neighborhood farm stands offers food and friendship," online news by Cincinnati, posted July 21, 2014, http://www.soapboxmedia .com/features/072214-findlay-market-farmstands.aspx.

34 "Education," Farmers Market Coalition web page, accessed January 16, 2016, https://farmersmarketcoalition.org/education/preserve-farmland-and-rurallivelihoods/.

35 Ibid.

36 Ibid.

\section{CONCLUSION}

1 John Brinckerhoff “J.B." Jackson, A Sense of Place, a Sense of Time (New Haven: Yale University Press, 1996), 152.

2 https://www.pps.org/category/placemakingSee also "What is Placemaking?" Project for Public Spaces, 2007, https://www.pps.org/article/what-is-placemaking.

3 "Eleven Principles for Creating Great Community Places," website accessed May 14, 2019, https://www.pps.org/article/11steps.

4 “District Development," Findlay Market website accessed April 16, 2019, http:// www.findlaymarket.org/district-development.

5 "Market Square," Model Properties website accessed April 16, 2019, https:// modelproperties.net/properties/market-square/. 


\section{IMAGE CREDITS}

All images, unless otherwise noted, are courtesy of the author, Kathryn Clarke Albright

O.I The image entitled "Market Mornings" by Bradley Collins is used here by permission of Bradley Collins. Copyright (C) 2013 by Bradley Collins.

o.8 The image is used here by permission of Erin Glass, Corporation for Findlay Market

o.9 Copyright (C) 2012 by Gwynn Hamilton and Bert Webster

o.ro Drawing courtesy of Caitlin Hyland

o.II Drawing courtesy of Caitlin Hyland

o.I4 The image entitled 'Roanoke City Market' by Cat Piper is used here by permission of Cat Piper. Copyright (C) 2019 by Cat Piper

o.I5 Photograph by Cards84664, licensed under CG BY-SA 4.o, via Wikimedia Commons. https://commons.wikimedia.org/wiki/File: West_Side_Market_(2018).jpg

I.7 Copyright (C) 2019 by Alireza Borhani Haghighi

I.8 Drawing courtesy of Reza Mousavynejad

I.9 Photograph courtesy of Aneela Jain

2.I Photograph courtesy of National Archives, photograph no. $83^{-G-4743}$ B

2.2 Image courtesy of Quinn Evans Architects

2.3 Drawing courtesy of Reza Mousavynejad

2.4 Copyright (C) 2019 by Alireza Borhani Haghighi

2.5 Copyright (C) 2019 by Alireza Borhani Haghighi

2.6 The image is used by permission of the photographer, Adam P. Fagen. https://www.flickr.com/photographs/afagen

2.7_Copyright @ 20Ig Wade Sisler

2.8 Image courtesy of Quinn Evans Architects

2.9 Image courtesy of Quinn Evans Architects

2.IO Image courtesy of Quinn Evans Architects 


\section{Image Credits}

2.II Image courtesy of Quinn Evans Architects

2.12 Courtesy of the Kenton County Public Library, Covington, Kentucky

2.I3 Photograph by Wholtone, licensed under CC BY 3.o. https://commons. wikimedia.org/wiki/File:Inside-findlay-market.jpg

2.I4 The image is used here by the permissions of the Corporation for Findlay Market

2.I5 Photograph by Joe D. Good, licensed under CC BY-SA 4.o. https:// commons.wikimedia.org/wiki/File:Findlay_Market_View_3.JPG

2.16 Copyright (C) 2019 by Alireza Borhani Haghighi

2.I7 Copyright (C) 2019 by Alireza Borhani Haghighi

2.18 Photograph by Brett Krouskop, licensed under CC BY-SA 2.o. https:// www.flickr.com/photographs/934270r7@No3/

2.19 The image is used here by permission of Erin Glass, Corporation for Findlay Market

2.20 The image is used here by permission of Erin Glass, Corporation for Findlay Market

3.2 Copyright (C) 2019 by Alireza Borhani Haghighi

3.3 Photograph courtesy of W. Garrett Jackson

3.4 Copyright (C) 2019 Tyler Peterson

3.IO Copyright (C) 20I9 Tyler Peterson

3.19 Drawing courtesy of Reza Mousavynejad

3.20 Drawing courtesy of Reza Mousavynejad

3.2I (C) Jeff Goldberg/ESTO

3.22 (C) Jeff Goldberg/ESTO

4.I Photograph courtesy of Jodi La Coe

4.2 Copyright (C) 20I4 Joshua Wilson

4.4 Photograph courtesy of Aneela Jain

4.5 Photograph courtesy of Aneela Jain

4.6 Photograph courtesy of Aneela Jain

4.7 Image courtesy of Quinn Evans Architects

4.8 Copyright (C) 20I4 Patrica Palermino

4.9 Copyright (C) 2014 Patrica Palermino

4.IO Photograph courtesy of Jodi La Coe

4.II Image care of Charlottesville Park \& Recreation

4.12 Copyright (C) 20I4 Joshua Wilson

4.I5 Image care of Charlottesville Park \& Recreation

5.I Image courtesy of Arcadia Center for Sustainable Food \& Agriculture 


\section{Image Credits}

5.2 Image courtesy of Arcadia Center for Sustainable Food \& Agriculture

5.3 Image courtesy of Arcadia Center for Sustainable Food \& Agriculture

5.4 The image with "Real Food Farm" is used here by permission of Civic Works

5.5 Image used here by permission of Urban Growers Collective

5.6 Image used here by permission of Urban Growers Collective

6.I Copyright (C) 2018 by Travis Estell

6.2 Copyright (C) 2017 by Travis Estell 


\section{WORKS CITED}

\section{Books}

Leon Battista Alberti, On The Art of Building in Ten Books

Anna Blessing, Locally Grown: Portraits of Artisanal Farms from America's Heartland

Brian Halweil, Eat Here: Reclaiming Homegrown Pleasures in a Global Supermarket

John Brinckerhoff "J.B." Jackson, A Sense of Place, a Sense of Time

Lucy R. Lippard, The Lure of the Local: Senses of Place in a Multicentered Society

Donlyn Lyndon and Charles Moore, Chambers for a Memory Palace

Christian Norberg-Schultz, Genius Loci: Towards a Phenomenology of Architecture

Helen Tangeris, Public Markets and Civic Culture in Nineteenth Century America

\section{Journal Articles}

Robert Sommer, John Herrick, and Ted R. Sommer, "The Behavioral Ecology of Supermarkets and Farmers' Markets," Journal of Environmental Psychology i, no. I

Marc Francis and Lucas Griffith, "The Meaning and Design of Farmers'

Markets as Public Space: An Issue-Based Case Study," Landscape Journal 30, no. 2 


\section{SUGGESTED READINGS}

Wendell Berry, Bringing It to the Table: On Farming and Food

Janine MacLachlan, Farmers' Markets of the Heartland

Jennifer Meta Robinson and J. A. Hartenfeld, The Farmers' Market Book: Growing Food, Cultivating Community

Thomas A. Lyson, Civic Agriculture: Reconnecting Farm, Food and Community Helen Tangeris, Public Markets

Mark Winne, Closing the Food Gap: Resetting the Table in the Land of Plenty 


\section{WEBSITES CITED}

http://www.abingdonfarmersmarket.com/

https://www.alexandriava.gov/OldTownFarmersMarket/

http://arcadiafood.org/

http://blacksburgfarmersmarket.com/

http://www.bluebirdmeadowsnc.com/

http://www.calhounhams.com/

https://www.charlottesville.org/departments-and-services/

departments-h-z/parks-recreation/city-market

https://www.chicagobotanic.org/

http://www.chicagolights.org/

https://www.chicago.gov/city/en/depts/dca/supp_info/

farmersmarkets $4 . h$ tml

https://www.commongoodcityfarm.org/

http://covingtonfarmersmarket.com/

http://www.cvillepedia.org/

http://www.designbuildlab.org/

http://durhamcentralpark.org/

https://durhamfarmersmarket.com/

http://www.ellencassillyarchitect.com

http://easternmarket-dc.org/

https://www.farmersmarketcoalition.org/

https://findlaykitchen.org/ 


\section{Websites Cited}

http://www.findlaymarket.org/

http://www.fourleaffarm.org/

http://freshfarmmarkets.org

http://www.freshtruck.org/

https://www.greencitymarket.org/markets/LincolnPark.asp

https://www.harrisonburgfarmersmarket.com/

http://www.historicstaunton.org/

http://www.hotspringsfarmersmarket.com/

http://nfmd.org

https://pomegranatecenter.org/

https://www.pps.org/

http://radicalrootsfarm.com

http://realfoodfarm.civicworks.com/

http://realfoodfarm.civicworks.com/cause/mobile-farmers-market/

http://www.safarmersmarket.com

https://stauntonfarmersmarket.org/

http://www.seedsnc.org

https://urbangrowerscollective.org/

https://www.wholesomewave.org/ 


\section{INDEX}

A

Abingdon Farmers Market, Abingdon, Virginia, 69-80, 98

Alberti, Leon Battista, 27

Allegheny Foundation, Covington, Virginia, 92, 94

Allegheny Highlands Chamber of Commerce and Tourism, Covington, Virginia, 92

Appalachian Food Roots Cooperative, 76

Appalachian Organics Farm, Abingdon Farmers Market, 76

Appalachian Sustainable Development, Abingdon, Virginia, 69, 74, 77,79

Arcadia Center for Sustainable Food and Agriculture, Washington, DC, 139

Arcadia Farm, Washington, DC, 139

Arcadia Mobile Market, Washington, DC, 139-141

\section{B}

Bare Knuckle Farm, Green City Farmers Market, 34

Blacksburg Farmers Market, Blacksburg, Virginia, 13, 22-23, 25-27, 29-31, $65-66,153,156$

Bluebird Meadows Farm, Durham Farmers Market, 86-87

Blue Iris Flowers, Eastern Market, 44-45

Bowers Fancy Dairy Products, Eastern Market, 43-44
C

Calhoun's Ham House, Old Towne Farmers Market, 113-114

Canales Deli, Eastern Market, 44

Capitol Market, Charleston, West Virginia, 10, 32

Caromount Farm, City Market, 120, 123

Cassilly, Ellen, Durham Farmers Market, 83,90

Celebration Farmers Market, Celebration, Florida, 16

Central Market, Lancaster, Pennsylvania, 4, 29, 39

Charles Bare Meats, Findlay Market, 58-59

Charleston Farmers Market, Charleston, South Carolina, 4

Charlottesville Office of Economic Development, 119, 123

Chicago Botanic Garden, 147

Chicago Lights Urban Farm, Chicago, Illinois, 138, 146-147

Churchill's Fine Teas, Findlay Market District, 60

Cincinnati Bell Connector, 155-156

Cincinnati Department of Economic Development, 59

Cincinnati Department of Public Works, 59

City Farm, Cleveland, Ohio, 138, 148 
City Market, Charlottesville, Virginia, $108,117-124$

Civic Garden Center, 149

Civic Works, Baltimore, Maryland, 142

Cluss, Adolph, Eastern Market, 46-47, 53, 109

Common Good City Farm, Washington, DC, 139

Community Nutrition Partnership, Veggie Van, 143

Community Supported Agriculture (CSA), 87, 143, 147

Corporation for Findlay Market, Cincinnati, Ohio, 59-60, 149, 154

Country Rhodes Produce \& Bakery, Staunton, Farmers Market, 128, 130

Covington Farmers Market, Covington, Virginia, 69-70, 90-99

Covington Farmers Market Steering Committee, Covington, Virginia, 95

Cuyahoga Metropolitan Housing Authority, Cleveland. Ohio, 138, 148

D

Del Rey Farmers Market, Alexandria, Virginia, 116

Department of General Services, Alexandria, Virginia, 116

Department of Real Estate Service (DRES), Washington, DC, 48-49

Department of Parks and Recreation, Charlottesville, Virginia, 122, 124

design/buildLAB, Covington Farmers Market, 91, 94

Double Dollar Program, see SNAP Double Value Program

Drath, Wilfred and Charles Palus, 29

Durham Farmers Market, Durham, North Carolina, 6, 69, 80-90, 98
E

Eastern Market, Washington, DC, 6, 11, 16, 37-53, 63, 106-107

Eastern Market Community Advisory Committee (EMCAC), 49

Elk Run Farm, Staunton Farmers Market, 132

\section{$\mathrm{F}$}

Farm Alliance, 143

Farmers Market Coalition, 150

Federal Plaza Farmers Market, Chicago, Illinois, 104-105

Ferry Market, San Francisco, California, ix, 32

Findlay Kitchen, Cincinnati, Ohio, 61

Findlay Market, Cincinnati, Ohio, 3-6, 10-11, 40-41, 53-64, 107, 154-156

Findlay Market (Urban) Farms, Cincinnati, Ohio, 149

Fifth Third Pavilion, Lexington, Kentucky, 68

Flaccavento, Anthony, 69, 76-79

Food Desert Action, 145

Forest Grove Famers Market, Forest Grove, Oregon, 35

Four Leaf Farm, Durham Farmers Market, 88-90

Four Mile Run Farmers and Artisan Market, Alexandria, Virginia, 116

Fresh Moves Mobile Market, Chicago, Illinois, 144-146

Fresh Truck, Boston, Massachusetts, 136-137

Friends of the Farmers Market, Blacksburg Farmers Market, ix, bio 


\section{Index G - N}

G

Gable, Bill, 70-71

Gadsby Commercial Urban Renewal Project, Alexandria, Virginia, 109

Gilbert, Alfred West, Findlay Market, 52, 63

Glade Road Growing, Blacksburg, Virginia, 34

Glaserworks, Findlay Market, 63, 63

GoodFood Mobile Market, Chicago, Illinois, 147

Green City Market, San Francisco, California, 33-34, 104, 106

Growing Power, Milwaukee, Wisconsin, 145,147

\section{$\mathrm{H}$}

Harrisonburg Farmers Market, Harrisonburg, Virginia, 98-99

Historic Staunton Foundation, Staunton, Virginia, 125-127

Homestead Hill Farm, Staunton Farmers Market, 130-131

Historic Downtown Market, Hot Springs, Arkansas, 99

\section{I}

Ithaca Farmers Market, Ithaca, New York, 68-69

$J$

Jackson, John Brinckerhoff, “J. B.”, 24, 151

Jacobs, Jane, viii

J. E. Gibbs Cheese, Findlay Market, 58

L

L'Enfant, Pierre, 16
Lilburn Farmers Market, Lilburn,

Georgia, 150

Lippard, Lucy, 24, 124

Little Rock Farmers Market, River Market District, Little Rock,

Arkansas, 6, 68

Longhorn Beef, Staunton Farmers Market, 128-129

Lowcountry Street Grocery, Charleston, South Carolina, 136

Lyndon, Donlyn, viii

\section{$\mathrm{M}$}

Mandel, Abbey, Green City Market, San Francisco, California, 33

Market Lunch, Eastern Market, 45

market house, 16, 31, 38-39. 67, 108

Market Central, 121-122

Market Ventures, Inc. 122-123

Mayor Adrian Fenty, Eastern Market, 51

Mayor Raum Emanuel, Fresh Moves

Mobile Market, 145

Mayor Ron Rordam, Blacksburg Farmers Market, 26

McKinney, Harry, 79

Mehl's Bakery, Abingdon Farmers Market, $77-78$

Midland Trail National Scenic Byway, 70,93

Moore, Charles, viii

$\mathrm{N}$

National Preservation Act, 56

National Register of Historic Places, 56

National Trust for Historic Preservation, 125

Neil Luken Meats, Findlay Market, 58 
Norberg-Schultz, Christian, 27

North Union Farmers Market, Cleveland, Ohio, 11

Number One Sons, Old Towne Farmers Market, 114-115

O

Ohio City Fresh Food Collaborative, Cleveland, Ohio, 148

Office of Economic Development, Charlottesville, Virginia, 119, 123

Old Towne Farmers Market, Alexandria, Virginia, 101-103, 108-116

O’Neil, David, 122

\section{P}

Palermino, Patricia, Old Towne Farmers Market, 110-112

placemaking, ix, 19, 137, 151, 153

Pollan, Michael, 31

Project for Public Spaces (PPS), ix, 151

Q
Quinn Evans Architects, Eastern Market, 50,53

\section{$\mathbf{R}$}

Radical Roots Community Farm, City Market, 120-121

Reading Terminal Market, Philadelphia, Pennsylvania, 6

Real Food Farm, Baltimore, Maryland, 142-143

Real Food Farm Mobile Market, Baltimore, Maryland, 142

Resale vendors, 5

Roffey Cattle Company, Abingdon Farmers Market, 75-76

\section{$\mathrm{S}$}

scale(s) of interaction and interface, 6,8 , 41,152

sense of place, viii, 24, 28, 64, 101, 133, 157

Smith, Baird, 50

SNAP Double Value Program, 35, 74, 112

SNAP Plus Program, 61, 63

Snow Spring Farm, Staunton Farmers Market, 131

SOAR Farmers Market, Chicago, Illinois, 104-105

South Eastern Efforts Developing Sustainable Spaces (SEEDS), 82, 84-86, 143-144

Staunton Farmers Market, Staunton, Virginia, 108, 125-133

Supplemental Nutrition Assistance Program (SNAP), x, 24, 35-36, 61-62, $74,82,112,136,139,140,142,-143$, 149,153

T

Tangeris, Helen, 32

Thomas Calomiris \& Sons, Eastern Market, 42-43

Thompson \& Litton, Abingdon Farmers Market, 79

The Green Machine Mobile Food Market, Memphis, Tennessee, 137

The Rooftop Garden, McCormick Place West, Chicago, Illinois, 138, 147-148

The Pavilion at Constitution Park, Waynesboro, Virginia, 66

U

Urban Growers Collective, Fresh Moves Mobile Market, 146 
Index U - Z

United States Department of Agriculture National Farmers Market Directory, viii

USDA Double Value Program, see SNAP Double Value Program,

USDA Secretary Vilsack, 145

\section{$\mathrm{V}$}

Veggie Van, Durham County, North Carolina, 143

Virginia Creeper Trail, 78

Virginia Tobacco Commission, 77

W

Waters, Alice, Chez Panisse, Berkeley, California, 17

West End Farmers Market, Alexandria, Virginia, 116

West Side Market, Cleveland, Ohio, 14-15

Wholesome Wave, 35

Whyte, William H. "Holly", viii

Windy City Harvest (WCH), Chicago

Botanic Garden, 147-148

\section{Z}

Zawistowski, Marie and Keith, 70, 91, 93-94, 97-98 


\section{AUTHOR BIO}

Kathryn Clarke Albright is a professor in the School of Architecture + Design at Virginia Tech, where she teaches undergraduate students at multiple levels of the architecture program. Albright has served as Associate Dean for Academic Affairs in the College of Architecture \& Urban Studies since 2016. Prior to coming to Virginia Tech, she practiced from 1986 to 1993 in San Francisco as a partner with Solomon, Inc. focusing on urban design and various scales of residential projects. In 1994 she earned a Master of Design Studies from Harvard University's Graduate School of Design. Albright's research focuses on the multiple scales of the urban condition that includes work with the Blacksburg Farmers Market. In 200I she founded, Friends of the Farmers Market, a 50 orc3 non-profit in Blacksburg and led the efforts that resulted in the 2009 opening of Market Square Park, with its timber-framed pavilion. 